Robinson Antonio Vieira Borba

\title{
A Cidade Cognitiva: Proposição para o Desenvolvimento Local na Era do Conhecimento
}

Universidade de São Paulo

2000 
Robinson Antonio Vieira Borba

Engenheiro Civil, Universidade Federal do Paraná, 1974.

Mestre em Engenharia Civil, Universidade de São Paulo, 1992.

\title{
A Cidade Cognitiva: Proposição para o Desenvolvimento Local na Era do Conhecimento
}

\author{
Tese de Doutoramento \\ Orientador: \\ Prof. Dr. Ualfrido del Carlo
}

Faculdade de Arquitetura e Urbanismo

Universidade de São Paulo

2000 
FICHA CATALOGRÁFICA

BORBA, ROBINSON ANTONIO VIEIRA

A CIDADE COGNITIVA - PROPOSIÇÃO PARA O DESENVOLVIMENTO LOCAL NA ERA DO CONHECIMENTO

R. A. V. BORBA - SÃO PAULO, 2000 - 344 P.

Tese (Doutorado) - Faculdade de Arquitetura e Urbanismo da Universidade de São Paulo. Departamento de Tecnologia. Orientador: Ualfrido Del Carlo

1. urbanismo 2. desenvolvimento urbano 3. desenvolvimento local 4. desenvolvimento econômico 5. desenvolvimento industrial 6. globalização I. Universidade de São Paulo. Faculdade de Arquitetura e Urbanismo. Departamento de Tecnologia. II. t. 


\section{A CIDAdE COGNITIVA: PROPOSIÇÃO PARA O DESENVOLVIMENTO LOCAL NA ERA DO CONHECIMENTO}

R. A. V. BORBA - SÃO PAULO, 2000 - 344 P.

\section{Resumo}

Formular uma proposição para processos de desenvolvimento local a serem institucionalizados por organizações governamentais e/ou nãogovernamentais nas comunidades através de ações destinadas a estimular a conexão entre economia regional e mundial é o objetivo deste estudo. Esta preocupação advém de que os modelos econômicos baseados em localidades, concebidos e estruturados através da percepção dos indivíduos, enquanto seres intelectuais e capazes de contribuir com sua cultura e sua criatividade para o crescimento econômico local, necessitam de um processo coletivo para a criação e condução de ações de desenvolvimento endógenas. Percebeu-se que há urgência de uma mudança radical na mentalidade coletiva como a que determinou a importância da tecnologia na Revolução Industrial no processo de transformação da sociedade agrária na sociedade industrial. Agora, com a metamorfose desta na sociedade digital, a relevância é a cognição, onde a meta é o entendimento do entrelaçamento do microcosmo da localidade com a dimensão mundial, para estabelecer um modelo de desenvolvimento econômico através da capacidade da sociedade de planejar e conduzir sua própria experiência local. A proposição desta tese é que esta capacitação, normalmente função do desenvolvimento institucional decorrente de um processo histórico, se desencadeie nas regiões a partir de um processo cognitivo coletivo. O conhecimento, onde se encontram elementos que possibilitam a compreensão de relações complexas e abstratas, como as econômicas, dessa maneira gerenciado, deverá estabelecer formas de organização e julgamento das idéias e conceitos necessários para a construção de um modelo original resultante de características culturais da população, que dessa maneira poderá contribuir para o desenvolvimento sustentável global com criatividade e inovação.

Palavras-chave: urbanismo - desenvolvimento urbano - desenvolvimento local desenvolvimento econômico - desenvolvimento industrial - globalização. 


\title{
THE COGNITIVE CITY: PROPOSAL FOR LOCAL DEVELOPMENT IN THE KNOWLEDGE ERA
}

R. A. V. BORBA - SÃO PAULO, $2000-344$ P.

\begin{abstract}
To formulate a proposition for local development processes to be institutionalized by both governmental and non-governmental organizations in the communities, through actions bound to stimulate the connection between regional and world economies is the aim of this work. This concern derives from the fact that the economic models based on localities, conceived and structured through the perception of individuals, while intellectual beings and capable of contributing with their culture and creativity to the local economic growth, need a collective process for generating and conducting endogenous development actions. It was perceived that a radical change in the collective mind urged, as the one which determined the importance of technology in the Industrial Revolution in the process of transforming a rural society into an industrial one. Now, with the metamorphosis of this digital society, the relevance is cognition. The goal is the understanding of the locality micro cosmos interwoven with the world dimension, so as to establish a model for economic development through society's ability to plan and conduct its own local experience. This thesis proposition is that this capacitating, usually a function of institutional development deriving from a historical process, is unleashed in the regions from a collective cognitive process. Knowledge, where elements are found that allow understanding complex and abstract relations, such as the economic ones, thus managed, will establish forms for organizing and assessing the ideas and concepts necessary to set an original model that can be a result of the cultural characteristics of the population, which may contribute for global sustainable development with creativity and innovation.
\end{abstract}

Key-words: urbanism - urban development - local development - economic development - industrial development - globalization. 
Para Cris, Gil e Rita. 


\section{Agradecimentos}

Ao meu orientador Professor Doutor Ualfrido del Carlo pelo incentivo, aconselhamento e paciência, sem os quais o desenvolvimento desta tese não teria sido possível.

Aos Professores Doutores Wilson Jorge e Emílio Haddad pela participação e comentários no exame de qualificação.

Aos amigos e colegas da FAU, IPT, SCTDE/SP, ADETEC e das comunidades de Ourinhos e Londrina que comigo compartilharam reflexões, contribuindo para o aperfeiçoamento das idéias contidas neste trabalho.

À minha mãe Inah Vieira Borba pelo permanente apoio e carinhosa atenção durante meus estudos e pesquisas em Londrina. 


\section{Prefácio}

Em 1994, a economia de Londrina passava por dificuldades. Pólo das atividades econômicas do Norte do Paraná, agora perdia sua dinâmica, com desemprego e falta de investimentos produtivos diversificados. A percepção de que este fato era decorrente do esgotamento do modelo econômico, ancorado no tradicional mercado de produtos agrícolas regionais, levou-me a acreditar que a reformulação deste modelo deveria contribuir para a retomada de seu crescimento. E mais, se este modelo fosse aplicável de forma genérica em diferentes regiões, ele justificaria o objetivo dos estudos de uma tese de doutoramento, pois este problema, com certeza, deveria estar ocorrendo em muitas outras cidades de forma semelhante.

Identificada esta questão em minha cidade natal, procurei compartilhar minha observação sobre sua decadência econômica em conversas informais com empresários locais, o que resultou na idéia de tirar proveito do fenômeno da relocação de indústrias globais, fomentando o fluxo de capital internacional a direcionar seus investimentos industriais para a cidade. A visão era que a industrialização, ainda incipiente na região, poderia desempenhar um papel mais importante para reaquecer a economia em Londrina.

Para condução das ações de marketing junto a grandes empresas nacionais e internacionais, Valter Luiz Guimarães, londrinense, executivo da holding petrolífera Ipiranga, apontou a necessidade de se ter em mãos um diagnóstico de alta qualidade, com confiabilidade empresarial, sobre a competência e vocação regional para a industrialização.

Em dezembro de 1994, após articulações dos empresários com a Prefeitura, foi contratada a empresa Andersen Consulting para elaborar o Plano de Desenvolvimento Industrial de Londrina (PDI). Junto ao comitê executivo, durante o ano de 1995, atuei em várias reuniões, debates e seminários, discutindo questões de planejamento estratégico aplicado à cidade.

Em 1996 e 1997, como consultor contratado pelo IPT, participei da elaboração do plano "Estratégia Competitiva do Estado" da SCTDE/SP com trabalhos na área de pólos tecnológicos e desenvolvimento econômico local, levantando ampla bibliografia de referência sobre estes temas nas bibliotecas do 
IPT e da Universidade de São Paulo (USP), na Faculdade de Arquitetura e Urbanismo (FAU), na Escola Politécnica (POLI) e na Faculdade de Economia, Administração e Ciências Contábeis (FEA), além de livrarias normais e virtuais, sites de Internet, revistas e jornais. No mesmo período, ministrei palestras sobre as ADLs em seminários promovidos pela SCTDE/SP em cidades do interior paulista e participei de reuniões com lideranças regionais visando a criação de um fórum de agências de desenvolvimento local do estado de São Paulo.

Durante os trabalhos para o IPT, pude verificar a importância que a tecnologia poderia ter como fator indutor do desenvolvimento regional, o que me levou a acreditar que haveria, neste enfoque, um modelo de desenvolvimento econômico viável para ser implantado em minha cidade natal. Esta possuía características de um pólo tecnológico, algumas delas com projeção nacional como a Universidade Estadual de Londrina (UEL), o Serviço de Comunicações Telefônicas de Londrina (SERCOMTEL), o Instituto de Pesquisas Agronômicas do Paraná (IAPAR).

Incentivado por meu orientador, passei a desenvolver conceitos e teorias que fossem aplicáveis às condições regionais de desenvolvimento da "capital" do Norte do Paraná, buscando conduzir as pesquisas à identificação de um modelo de desenvolvimento econômico local fundamentado em indústrias de base tecnológica.

Isto me levou a estudar as condições encontradas na Emilia-Romagna, com a qual Londrina possui contato permanente, graças ao Programa ParanáEuropa existente na cidade, cujo escritório tem levado lideranças locais em visitas a esta região da Itália, conhecida internacionalmente pela economia fundamentada em uma rede de pequenas e médias empresas, a maioria delas dedicada a produtos de alta tecnologia.

As investigações se estenderam ao Japão, país que tem recebido um grande número de "dekasseguis" oriundos de Londrina, que após trabalharem em fábricas de todos setores, inclusive de alta tecnologia, voltam para a cidade com recursos para investir na região. Porém, por falta de opções, acabam se restringindo em investimentos imobiliários, urbanos e rurais. Transferência de tecnologia e processos produtivos inovadores poderiam ser assimiláveis pela cultura regional, pois estes trabalhadores, servindo de facilitadores, seriam 
potenciais empreendedores. O modelo japonês de desenvolvimento regional baseado na implantação do Programa das Tecnópolises, regiões cuja estruturação produtiva é fundamentada na inovação tecnológica.

A identificação de cadeias produtivas em segmentos industriais na área de alimento e confecções "clusters" pelo PDI de Londrina, fizeram-me conduzir pesquisas às aglomerações industriais, buscando um modelo de desenvolvimento industrial assemelhado ao processo de organização espontânea, até aqui identificado em Londrina, encontrando no Instituto de Pesquisas Econômicas Aplicadas (IPEA) excelentes levantamentos sobre regiões e cidades médias industrializadas brasileiras.

Nos anos de 1997 e 1998, a criação da Agência de Desenvolvimento Econômico de Ourinhos (ADEO), através de contrato com a Prefeitura Municipal local, foi uma excelente oportunidade de aplicação dos conceitos e teorias abordados em meus estudos. Atuei na ADEO como diretor técnico, sendo responsável pela formulação de seu plano estratégico, quando convivi com dificuldades culturais e institucionais para motivar a inovação gerencial e tecnológica, não apenas nas micro e pequenas empresas locais, como também no setor público. Assim, mesmo com apoio de importantes instituições, como o Serviço Brasileiro de Apoio às Micros e Pequenas Empresas (SEBRAE) e a Universidade Estadual de São Paulo (UNESP), não se conseguiu evitar o fracasso do principal projeto da ADEO: a incubadora empresarial.

O trabalho em Ourinhos permitiu uma aproximação maior com Londrina. Graças à proximidade entre as duas cidades, pude acompanhar de perto os esforços para a formatação de um pólo tecnológico na região do Norte do Paraná. Em 1998, ao final do trabalho na ADEO, fui contratado pela Prefeitura da cidade paranaense para a criação de uma agência de desenvolvimento regional, visando a implantação da Região Metropolitana de Londrina.

Até o final de 1999, o convívio com a comunidade londrinense foi intenso, tendo participado de duas jornadas tecnológicas promovidas pela Associação de Desenvolvimento Tecnológico (ADETEC). Em 1998, como representante da Secretaria de Planejamento Municipal e, em 1999, com palestra sobre a agência de desenvolvimento. 
Encerro agora esta tese concluindo, após levantamentos bibliográficos e documentais, observações pessoais da minha experiência profissional, estudos e análises, que não há possibilidade da construção de um modelo de desenvolvimento econômico que não seja original. Ou seja: se há um modelo, ele é único e cultural, servindo apenas para aquela sociedade que o originou. O que é um paradoxo.

A predominância de um modelo de desenvolvimento, como se assiste hoje, é fruto de uma forte articulação institucional, amplo poder organizacional e homogeneização de valores culturais localizados que, entre outros fatores, como o tecnológico, garante sua expansão ao mercado global. A globalização é o inverno que se aproxima e não há como evitá-lo, mas a simples assimilação deste seu modelo não garante a competitividade de regiões brasileiras.

Não há como se enfrentar o problema de exclusão das economias periféricas sem transformar, a priori, a mentalidade dos agentes responsáveis pela governança das localidades e, também, de seus cidadãos. Deve-se cuidar do uso da evolução tecnológica para estimular as economias regionais, mas há de se empreender um amplo processo cognitivo coletivo para permitir a capacidade endógena de desenvolvimento.

Desenvolvimento econômico, mais que simples questão tecnológica, é um problema cultural.

São Paulo, junho de 2000 


\section{Apresentação}

Formular uma proposição para contribuir com processos de desenvolvimento local a serem institucionalizados por organizações governamentais e/ou não-governamentais nas comunidades através de ações destinadas a estimular a conexão entre economia regional e mundial, foi o objetivo do estudo.

Os modelos econômicos baseados em localidades, concebidos e estruturados através da percepção dos indivíduos enquanto seres intelectuais e capazes de contribuir com sua cultura e sua criatividade para o crescimento econômico local, necessitam de um arcabouço conceitual que permita desencadear este processo com sustentabilidade, o que justifica esta pesquisa voltada para a introdução de processo cognitivo coletivo nas ações endógenas de planejamento.

Este preocupação se deu a partir da observação de que:

O meio técnico-científico-informacional, mostrando-se cada vez com maior complexidade, conduz e permeia todas as atividades humanas, em uma cadeia sucessiva de transformações sociais e econômicas que se materializam no espaço territorial das comunidades;

O conhecimento, sendo recurso deste meio, validaria a utilização e funcionamento do espaço local como locus da produtividade global, garantindo para as regiões o encontro entre as possibilidades latentes e as oportunidades criadas pela Nova Economia, e permitiria uma reação aos efeitos perversos que a globalização poderia estar trazendo para o desenvolvimento local.

Procurou-se, então, compreender:

Primeiro, o processo de desenvolvimento econômico local, extraindose aspectos teóricos e relatadas experiências internacionais e brasileiras através de ações estratégicas endógenas locais e regionais que visavam potencializar a capacidade produtiva das comunidades, normalmente aplicadas por agências de desenvolvimento;

Segundo, a tendência de industrializações descentralizadas, expontâneas, frutos de um processo histórico ou induzidas por instituições criadas por comunidades ou pelos governos centrais, especialmente para conectar as 
economias locais com a emergente economia global, através de qualificação tecnológica da base industrial existente e de atração de empreendimentos de base tecnológica;

Terceiro, o impacto que as transformações decorrentes da globalização acarreta nas localidades, com a complexidade que o fenômeno econômico-social impõe, fruto de condições criadas pelo circuito aberto da nova economia mundial.

A compreensão destes acontecimentos possibilitou deduzir que:

A economia local jamais deverá estar estanque para ser competitiva, pois muda seu cenário permanentemente e, hoje, tão rápido quanto os fluxos de informação que atravessam os continentes permeando as regiões;

As conquistas da civilização tecnológica cria barreiras na comunicação entre as sociedades, excluindo comunidades incapazes de compreender a complexidade das relações em mutação, o que causa ruído no desenvolvimento sustentável global;

O abismo do conhecimento é o desafio na estruturação econômica de localidades e regiões;

A destruição criativa imposta pela nova economia mundializada exige uma postura inédita nas comunidades: um processo cognitivo permanente;

Aprender para não morrer, este é novo paradigma determinado pela globalização nas localidades na era do conhecimento.

Adquirir conhecimento significa estimular criatividade e desembocar na inovação, que é fator de vitalidade e sobrevivência das organizações da nova economia e das comunidades dinâmicas do mundo globalizado.

Há urgência de uma mudança radical na mentalidade coletiva. Como a que determinou a importância da tecnologia na Revolução Industrial durante o processo de transformação da sociedade agrária na sociedade industrial. Agora com a metamorfose desta na sociedade digital a relevância é a cognição.

Peter Drucker (2000) considera que: "Aquilo que chamamos Revolução da Informação é, na realidade, uma revolução do conhecimento. A rotinização dos processos não foi possibilitada por máquinas. O computador, na verdade, é apenas o gatilho que a desencadeou. O software é a reorganização do 
trabalho tradicional, baseado em séculos de experiência, por meio da aplicação do conhecimento e, especialmente, da análise lógica e sistemática. A chave não é eletrônica, mas sim a ciência cognitiva".

Estas constatações demostraram:

Primeiro, a necessidade de se estabelecer um modelo de política para desenvolvimento econômico local dentro de uma estratégia endógena construída a partir de uma percepção da realidade regional;

Segundo, que a tecnologia se tornou indutora de atividades econômicas, porém, para que a elas dê sustentabilidade, não deve ser vista como fim mas como meio para proporcionar integração do sistema de desenvolvimento local à economia global com a abrangência e complexidade que a sociedade contemporânea exige.

E considerando-se que:

Concretizando-se nas regiões, onde se dá o encontro entre possibilidades e oportunidades, a chamada "Nova Economia", na qual ciência, tecnologia e informação são a base técnica da vida social, faz do conhecimento um recurso essencial para validar a utilização do espaço regional como locus da produtividade global;

A intensa complexidade de informações, permeando todas as atividades humanas sob impacto da cadeia sucessiva de transformações, materializa-se no espaço territorial das comunidades locais, as quais devem ser capacitadas para a condução de um modelo coerente com sua tradição e cultura, base que são para a criatividade e inovação, elementos dominantes na era do conhecimento;

O dimensionamento do patrimônio regional natural, cultural e tecnológico, é uma exigência para inserção de cadeias produtivas regionais no novo modo produtivo e deve ser avaliado em um quadro que preserve os espaços locais de produção.

Pode-se concluir que:

O entendimento do entrelaçamento do microcosmo da localidade com a dimensão mundial é vital para um modelo de desenvolvimento; 
A sustentabilidade deste modelo apenas pode ser obtida através da capacidade da sociedade de planejar e conduzir sua própria experiência local.

E, afinal, chega-se à proposição da tese:

Que esta capacitação, normalmente função do desenvolvimento institucional decorrente de um processo histórico, desencadeie- se a partir de um processo cognitivo coletivo viabilizando que o conhecimento, em que se encontram elementos que possibilitam a compreensão de relações complexas e abstratas, como são as da "Nova Economia", estabeleça as formas de organização e julgamento das idéias e conceitos necessários para a construção de um modelo original assimilável pela região de sua aplicação e, aperfeiçoando características culturais da população, contribua para o desenvolvimento sustentável global com criatividade e inovação.

Espera-se que com isto:

Constituam-se processos de civilidade nas comunidades brasileiras, capacitando-as para as inúmeras tarefas coletivas que os desafios da era do conhecimento, com complexidade, atendendo a necessidade da instituição de uma mentalidade inovadora coletiva; e, assim

As centenas de anos de história da prática cívica que foram necessárias para a modelagem do desenvolvimento de nações e localidades por suas sociedades colaborativas não sejam, assim, indispensáveis para desencadear em um país sem esta tradição, como o Brasil, processos que resultem em modelos de desenvolvimento econômico originais, pois estes seriam elaborados com criatividade e inovação pelas que poderiam, então, serem chamadas de cidades cognitivas.

Para se chegar a esta conclusão, a tese foi desenvolvida em 5 partes:

A primeira, abordando a inserção da tecnologia no processo da civilização humana faz a introdução do objeto da tese sob a perspectiva da transformação do conhecimento em recurso endógeno de desenvolvimento;

A segunda oferece um panorama sobre aspectos conceituais e teóricos do desenvolvimento econômico local, como o significado de "local" e desenvolvimento endógeno, apontando questões emergentes como agências de 
desenvolvimento local, empreendedorismo cívico e planejamento estratégico para a competitividade local. Ainda descreve experiências nacionais e internacionais em agências de desenvolvimento, aprofundando-se na criação da agência de desenvolvimento econômico de Ourinhos, cuja criação contou com a participação do autor desta tese, e nas agências de desenvolvimento propostas pelo plano "Estratégia Competitiva do Estado", formulado pelo Instituto de Pesquisas Tecnológicas - IPT - para a Secretaria da Ciência, Tecnologia e Desenvolvimento Econômico do Estado de São Paulo.

A terceira trata do desenvolvimento industrial descentralizado, descrevendo aglomerações industriais brasileiras em cidades fora dos eixos industriais tradicionais e a experiência italiana que ocorre na Emília-Romagna, cujo sucesso decorre, entre outros fatores, do desenvolvimento institucional histórico que criou uma dinâmica comunidade cívica na região. Esta seção destaca também o surgimento de pólos tecnológicos que seguem o padrão bem-sucedido do Silicon Valley nos EUA, detalhando o modelo de Sophia Antipolis na França. Como evolução do conceito de desenvolvimento regional baseado em industrialização voltada para alta tecnologia, é analisado o recente fenômeno das Tecnópolises, descrevendo a abrangente experiência japonesa. Esta seção é encerrada com a descrição do planejamento estratégico de industrialização de Londrina, onde estão sendo integrados o Plano de Desenvolvimento Industrial PDI -, elaborado pela empresa Andersen Consulting e o projeto Londrina Tecnópolis, desenvolvido pela ADETEC, uma organização não-governamental local.

A quarta traz a discussão da globalização para o cenário do desenvolvimento econômico local através da abordagem de algumas visões de estudiosos e pesquisadores internacionais, como Domenico de Masi, Anthony Giddens e Manoel Castells, e do brasileiro Milton Santos, os quais, colocando questões que afetam diretamente a problemática da economia regional, permitem criar um imaginário para a idealização da conexão entre a economia regional e a mundial. É destacada a complexidade das idéias abstratas que envolvem o modelo de desenvolvimento econômico global. 
A quinta mostra a conclusão com a fundamentação e a proposição para o problema do desenvolvimento local na era do conhecimento: a cidade cognitiva. 


\section{SUMÁRIO}

\section{Introdução, 1}

\section{Desenvolvimento Econômico Local, 12}

\section{Introdução, 13}

2. Aspectos do Desenvolvimento Econômico Local, 18

2.1 Conceito de Local, 18

2.2 Teoria do Desenvolvimento Econômico Local, 20

2.3 Desenvolvimento Endógeno, 22

2.4 Ativos Locais para o Desenvolvimento, 25

2.5 Política do Desenvolvimento Econômico Local, 31

2.5.1 Governança, 31

2.5.2 Papel do Setor Público, 33

2.5.3 O Estado Empreendedor, 35

2.5.4 A Comunidade Empreendedora, 45

2.5.5 Parcerias Público-Privadas, 47

2.6 Implantação do Programa de Desenvolvimento Local, 55

2.6.1 Planejamento Estratégico, 57

2.6.2 Missão, 61

2.6.3 Ações Estratégicas, 62

2.7 Atores do Desenvolvimento Local, 69

2.7.1 O Empreendedor Cívico, 71

\section{Agências de Desenvolvimento Econômico Local, 75}

3.1 Tipos de Agência de Desenvolvimento Local, 76

3.2 Estrutura da Agência de Desenvolvimento Local, 77

\section{Experiências de Agências de Desenvolvimento, 79}

4.1 Agências de Desenvolvimento Regional da Espanha, 79

4.2 Associação Européia de Agências de Desenvolvimento - EURADA, 82

4.2.1 Agência de Desenvolvimento como Observatório, 83

4.2.2 Classificação das Agências da EURADA, 84

4.2.3 Premissas para o Sucesso de uma Agência de Desenvolvimento, 86

4.2.4 Organização de uma Agência da EURADA, 87

4.3 Experiência Brasileira das ADLs em São Paulo, 90

4.3.1 Missão e Objetivos de uma ADL, 71

4.3.2 A ADL como uma ONG, 91

4.3.3 Beneficiários de uma ADL, 91

4.3.4 Constituição de uma ADL, 92

4.3.5 ADL Intermunicipal, 93

4.3.6 Atividades de uma ADL, 94

4.3.7 Fatores Críticos para o Sucesso da ADL, 97

4.3.8 Etapas para Implantação de uma ADL, 97

4.3.9 Parceiros Potenciais para uma ADL, 100

4.3.10 Avaliação da Implantação do Programa de ADLs, 102

4.4 Agência de Desenvolvimento Econômico de Ourinhos, 105

4.4.1 Histórico, 105

4.4.2 Oficina para Desenvolvimento Local de Ourinhos, 106

4.4.2.1 Ourinhos e a Globalização, 107

4.4.2.2 Problemas para Desenvolvimento de Ourinhos, 109

4.4.2.3 Equacionamento de Problemas de Ourinhos, 111

4.4.2.4 Pontos Fracos e Pontos Fortes de Ourinhos, 115

4.4.2.5 Marketing Público de Ourinhos, 118

4.4.3 Criação da Agência de Desenvolvimento Econômico de Ourinhos, 119

4.4.4 Missão da ADEO no Desenvolvimento de Ourinhos, 121

4.4.5 Ações Estratégicas da ADEO, 122

4.4.6 Implantação da ADEO, 124

4.4.7 Planejamento Estratégico do Desenvolvimento Local de Ourinhos, 125

4.4.8 Parcerias da ADEO, 135 
4.4.9 Resultados das Ações da ADEO, 135

4.4.10 Situação Atual da ADEO, 141

4.4.11 Avaliação do Desempenho da ADEO, 142

\section{Desenvolvimento Industrial Descentralizado, 146}

\section{Introdução, 147}

\section{Experiência Italiana, 148}

2.1 Origem do Desenvolvimento Descentralizado na Itália, 148

2.2 Desenvolvimento Industrial na Terza Itália, 157

2.3 A Competência Industrial de Módena, 159

\section{Industrialização Descentralizada no Brasil, 165}

3.1 Tipologia de Aglomeração Industrial, 167

3.2 Algumas Experiências no Brasil, 169

3.2.1 Americana, 169

3.2.2 Blumenau, 170

3.2.3 Campinas, 171

3.2.4 Colatina, 173

3.2.5 Criciúma, 174

3.2.6 Florianópolis, 176

3.2.7 Franca, 177

3.2.8 Santa Cruz do Sul, 178

3.2.9 Santa Rita do Sapucaí, 179

3.2.10 São Carlos, 180

3.2.11 Vale dos Sinos, 181

3.2.12 Votuporanga, 183

\section{Os Pólos Tecnológicos, 184}

4.1 Conceito, 184

4.2 Histórico, 185

4.3 O Modelo de Sophia Antipolis, 186

4.3.1 Introdução, 186

4.3.2 Políticas, objetivos e instrumentos, 187

4.3.3 Infra-estrutura e Organização, 187

4.3.4 Conclusão, 190

4.4 Experiência Brasileira, 192

4.4.1 Histórico, 192

4.4.2 Metas de um Pólo Tecnológico, 193

4.4.3 Requisitos Mínimos para Implantação, 193

4.4.4 Formatações Viáveis, 194

4.4.5 Atividades Básicas do Pólo Tecnológico, 194

4.4.6 Pólos com Estruturação Formal, 196

4.4.7 Gestão de Pólo Tecnológico, 197

4.4.8 Avaliação dos Serviços e Facilidades Oferecidos pelo Pólos, 197

\section{As Tecnópolises, 202}

5.1 Projetos de Tecnópolis no Mundo, 203

5.2 Programa de Tecnópolis no Japão, 206

5.2.1 Tecnópolis e Desenvolvimento Regional no Japão, 207

5.2.2 Concepção do Programa, 209

5.2.3 Implantação do Programa, 212

5.2.4 Avaliação do Programa nas Regiões, 219

5.2.4.1 Myagi, 220

5.2.4.2 Shinanogawa, 222

5.2.4.3 Oita, 225

5.2.4.4 Kumamoto, 229

5.2.5 Conclusão sobre o Programa Japonês, 232

\section{Desenvolvimento Industrial em Londrina, 239}

6.1 Histórico do Desenvolvimento Local, 239

6.2 Desenvolvimento Industrial, 244 
6.3 A Comunidade Empreendedora, 247

6.4 Plano de Desenvolvimento Industrial de Londrina, 249

6.4.1 Concepção, 249

6.4.2 Diagnóstico, 250

6.4.2.1 Setores Atuais, 250

6.4.2.2 Novos Setores, 253

6.4.2.3 Setores para Competitividade de Londrina, 259

6.4.3 Modelo de Desenvolvimento Industrial de Londrina, 260

6.4.4 Fatores Críticos para o Sucesso do PDI, 264

6.4.5 Situação Atual do PDI, 265

6.5 Projeto Londrina Tecnópolis, 266

6.5.1 Histórico, 266

6.5.2 Justificativa do Projeto Londrina Tecnópolis, 268

6.5.3 Etapas do Projeto, 269

6.5.4 Competências Tecnológicas de Londrina, 269

6.5.5 Empresas com Potencial Tecnológico de Londrina, 271

6.5.6 Mapeamento das Competências Tecnológicas, 272

6.5.7 Situação Atual do Projeto Londrina Tecnópolis, 273

6.6 O PDI e o Projeto Londrina Tecnópolis, 274

IV. Impacto da Globalização no Desenvolvimento Local, 282

1. Introdução, 283

2. Sociedade de Risco, 285

2.1 A Modernização Reflexiva, 285

2.2 O Conceito de Risco Fabricado, 285

3. Catástrofe Urbana, 290

4. Sociedade em Rede, 292

5. Limites do Estado, 296

6. Espaço e Tempo, 299

7. Desenvolvimento sem Trabalho, 302

\section{Conclusão - A Cidade Cognitiva: Proposição} para o Desenvolvimento Local na Era do Conhecimento, 304

1. O Problema: Desenvolvimento Local na Era do Conhecimento, 305

2. A Proposição: A Cidade Cognitiva, 325

2.1 Fundamentação, 325

2.2 Proposição, 326

VI. Notas, 331

VII. Bibliografia, 343 


\section{Lista de Quadros, Tabelas e Figuras}

Quadro 1: Idéias para Teoria de Desenvolvimento Econômico Local, 22

Quadro 2: Importância de Fatores Regionais na Logística Industrial, 28

Quadro 3: Importância de Atributos Regionais na Logística Industrial de Empresas de Alta Tecnologia, 29

Quadro 4: Fatores Influentes na Escolha de Regiões por Empresas de Alta Tecnologia, 30

Quadro 5: Mecanização da Cana na Região de Ourinhos, 112

Quadro 6: Saída dos Terminais de Petróleo de Ourinhos, 113

Quadro 7: Não Emprego na Região de Ourinhos - Cenário Tradicional, 114

Quadro 8: Não Emprego na Região de Ourinhos - Cenário Inovador, 115

Quadro 9: Estruturação Formal de Pólos Tecnológicos, 196

Quadro 10: Oferecimento e Utilização de Serviços/Facilidades dos Pólos, 198

Quadro 11: Avaliação pelas Empresas Associadas da Atuação dos Pólos, 199

Quadro 12: Avaliação pelas Empresas Universidades da Atuação dos Pólos, 200

Quadro 13: Estruturas para Pesquisa das Tecnópolis no Japão, 219

Quadro 14: Atributos para a Competitividade da Indústria de Confecção em Londrina, 252

Quadro 15: Análise da Atratividade dos Diferentes Setores Industriais para a Comunidade de Londrina, 255

Quadro 16: Atratividade de Setores Industriais para a Comunidade de Londrina, 256

Quadro 17: Análise de Adequação da Estrutura Urbana da Cidade de Londrina, 258

Quadro 18: Enfoques da Primeira e da Segunda Modernidade, 287

Tabela 1: Participação dos Setores no PIB Industrial de Londrina, 246

Tabela 2: Participação dos Setores Industriais na Geração de Empregos, 246

Figura 1: Ações Estratégicas para o Modelo de Desenvolvimento Industrial, 249

Figura 2: Atratividade Industrial vs. Adequação da Estrutura Urbana, 260 
I. Introdução 
"Tomou, pois, Deus, o homem e o colocou no jardim
do Éden para o cultivar e o guardar. E lhe deu esta
ordem: de toda árvore do jardim comerás
livremente, mas da árvore do conhecimento do bem
e do mal não comerás; porque no dia em que dela
comeres, certamente morrerás.

Gêneses, versículos 15,16 e $17^{1}$.

Sabe-se que o casal original ao experimentar o fruto da árvore do conhecimento, seduzido pelo poder do entendimento do bem e do mal, perdeu a confortável e equilibrada tranqüilidade ilibada da vida no Jardim do Éden, deixando para seus filhos e descendentes o atraente, porém pesado fardo da liberdade a ser carregado pelo caminho, ainda sinuoso, da autodeterminação no planeta. Assim nascia o novo homem, na morte do bem-estar eterno, surgindo este ser que desafiaria sua própria existência: o homo sapiens.

Antes que uma simples advertência divina à ansiedade humana, ponderando entre o bem e o mal derivados da manipulação do conhecimento, uma provocação à capacidade de gestão da infinita avalanche de informações que se faria necessária para o domínio de uma existência equilibrada na Terra, planeta vivo, em permanente mutação, ao qual se somaria a também evolução transformadora do processo civilizatório do ser humano.

Neste universo etéreo de textos sagrados, deuses e crenças buscam-se explicações, as quais, como brinquedos inteligentes, se encaixam a novas montagens e desmontagens, e nunca deixam de oferecer novas possibilidades no jogo da civilização que se renova a cada instante.

Renovação e esperança, uma "destruição criativa", como conta a lenda de Prometeu ${ }^{3}$ : 
"Zeus tinha muitos planos para a moldagem da criação. Ele não demonstrava interesse pela raça humana mortal em seu exuberante mundo, Zeus pretendia que os mortais vivessem como seres primitivos até morrer, dizendo que o conhecimento e as dádivas divinas apenas trariam miséria aos homens e insistiu para que Prometeu, que havia se condoído da situação dos humanos, não interferisse em seus planos para eles.

Mas, apesar do aviso de Zeus, Prometeu, com pena dos homens primitivos, deu aos mortais todo tipo de presentes, como: a alvenaria, a carpintaria, os números, o alfabeto, a carroça, a sela, o navio e a vela. Ele também ensinou os mortais a se orientar pelas estrelas, a manipular drogas, a astrologia, a mineração e todas as artes.

Para viabilizar suas intenções, Prometeu roubou de Zeus o fogo, que foi entregue aos mortais em suas escuras cavernas. O fogo divino provocou, então, uma corrente de inventividade, produtividade e, principalmente, respeito dos outros deuses do Olimpo com relação ao rápido desenvolvimento dos mortais. Antes, jamais havia existido cultura, arte e aprendizado nas terras ao redor do Olimpo. Quando Zeus percebeu a trapaça de Prometeu ele ficou furioso e ordenou que ele fosse acorrentado no alto de uma montanha e lá tivesse seu figado eternamente devorado por uma águia.

A raiva de Zeus não terminou com a vingança contra Prometeu. Fingindo dar mais um presente aos mortais, ele moldou uma odiosa criatura na figura de uma atraente jovem garota e a chamou Pandora, de cuja constituição todos os deuses do Olimpo participaram. Seu corpo foi feito por Hepheistos que também lhe sua voz. Athena lhe concedeu habilidade e inventividade. Afrodite colocou nela uma aura de encantamento em volta de sua cabeça e Hermes mesquinharia e perspicácia em seu cérebro. Ela estava pronta para o mundo. E, irresistivel como era, logo foi aceita pelos mortais como mais um presente do Olimpo. A maléfica missão do ser divino foi bem sucedida. Assim, quando a caixa que ela trazia foi aberta, maldade e desespero tomaram conta do mundo dos mortais. Desastres e doenças se espalharam por todos os cantos. Porém, depois que Pandora havia esvaziado sua caixa, ela percebeu que ainda havia algo dentro dela: a Esperança. O inacreditável, surpreendente último presente que Zeus havia reservado para a raça humana e que poderia, afinal, transformar sua vida amaldiçoada em uma benção".

Civilização é risco. Há de se desafiar, conquistar e dominar, entretanto sem perder a esperança, vista aqui como a possibilidade de resolver as questões 
I. Introdução

com o domínio do conhecimento sobre o risco da praticabilidade de exploração das propriedades físicas, químicas e biológicas do mundo natural.

Resta aos mortais compreender o que talvez seja a única imposição: a sustentabilidade de sua civilização deve estar intrinsecamente ligada à esperança, a qual, sob todas as incertezas, irá assegurar a continuidade do processo de desenvolvimento, que, por sua vez, não poderá ter sua capacidade de expansão definitivamente interrompida pelas perversas conseqüências que ele possa ter trazido.

É, assim, fortalecido pela compreensão e domínio das forças da natureza e da manipulação dos recursos naturais, que o mesmo processo, sustentado pela aplicação deste conhecimento, vem tomando conta do mundo desde o início da civilização, transformando-a e dirigindo-a no sentido de configurá-la como uma benesse e um legado de geração em geração.

Embora muitas vezes as transformações necessárias sejam postergadas em nome da estabilidade social e econômica ${ }^{4}$ de uma determinada época, ela se impõe pela evolução da técnica, que pode ser vista como resultado de três estágios de desenvolvimento: a técnica do acaso, a técnica do artesão e a técnica do técnico ${ }^{5}$.

Neste ponto chega-se ao que podemos reconhecer como tecnologia, o que seria o tecnicismo da técnica, entendida como resultado de uma matriz em que se assegura um lugar para a técnica e a compreensão de sua ciência, através do conhecimento.

Imbuída do espírito dos criadores ${ }^{6}$ da nova ciência que acompanhou o processo evolucionário do homem como parte do núcleo central do desenvolvimento de sua sociedade, a técnica transformou-se em sua variável fundamental: a tecnologia.

É a tecnologia que vem definindo a direção de implantação de uma sucessão transformadora, fruto do conhecimento cumulativo dos homens sobre a natureza e suas leis físico-químicas, determinando a continuidade do processo de desenvolvimento que a civilização vem experimentando, sem interrupção significativa. 
I. Introdução

Às técnicas, a princípio resultados apenas de conjuntos compostos de gestos repetitivos que se tornavam eficazes, haviam sido adicionadas alterações que resultaram em melhorias das ferramentas, que traziam em sua origem um lento e paciente esforço da sociedade produtiva sobre o mundo exterior.

A partir da aplicação de metodologias científicas, e graças ao entendimento da técnica produtiva como uma ciência das forças produtivas ${ }^{7}$, estas transformações tornaram-se elas mesmas tecnológicas, direcionadas por objetivos econômicos e ganharam autonomia, condicionada aos resultados obtidos em novas descobertas científicas.

Entretanto, embora ao processo de evolução tecnológica esteja constantemente sendo acrescentada uma nova e intrigante possibilidade de radical transformação, uma referência permanece definitiva, estabelecendo visões que passaram a ser consideradas sempre que se adentra ao labirinto de paradigmas em que se transforma o binômio tecnologia e desenvolvimento: a Revolução Industrial.

Ela marcou o enfraquecimento da economia agrária e artesanal, e ao incluir a adesão sistemática da pesquisa cientifica à produção industrial para um ganho que seria incorporado à rotina produtiva, garantindo à tecnologia um lugar de destaque no crescimento da economia dos séculos vindouros.

Afinal, era o desenvolvimento tecnológico da emergente economia industrial que estava permitindo os crescentes diferenciais competitivos. Assim, ao agregar maior valor ao produto industrial e criar um ciclo econômico altamente rentável para os investidores, a tecnologia se tornou importante investimento para o sucesso dos novos empreendimentos industriais.

Visando obter uma efeméride precisa, os historiadores chegaram a uma certa concordância quanto ao estabelecimento de uma data-referência do início da Revolução Industrial: 1769. Neste ano, James Watt, um escocês de Greennock, descobriu como corrigir uma significativa perda de energia térmica resultando em um aperfeiçoamento da máquina a vapor.

Esta melhoria tornou possível a utilização econômica deste equipamento, sendo feito seu uso pioneiro no bombeamento de águas em minas 
I. Introdução

de carvão, substituindo um custoso processo realizado até então manualmente através de baldes.

Obtida dentro da Universidade de Glasgow, a conquista provocou uma grande transformação na nascente economia industrial e serviu como um concreto estímulo à participação dos cientistas ligados às Academias de Ciências e Universidades no novo cenário econômico que se descortinava com a ampliação do mercado internacional e a necessidade de racionalização dos recursos naturais disponíveis na Europa.

Uma avalanche de novas idéias rapidamente foram aplicadas, a princípio, na Inglaterra e, em seguida, em outros países europeus que já estavam em uma fase embrionária dentro da nova economia industrial.

"As inovações tecnológicas do século XVIII, de tão abundantes, chegam a desafiar a tentativa de uma compilação. Mas podem ser resumidas em três principais: 1) o aparecimento de máquinas modernas - rápidas, regulares e precisas - que substituíram o trabalho do homem antes realizado a mão. Em outras palavras, um mecanismo que, acionado, passa a executar, com suas ferramentas e suas peças, as mesmas operações que antes eram executadas por ferramentas semelhantes movidas pela mão do homem; 2) a utilização do vapor para acionar a máquina, isto é, como fonte de energia, que substitui as demais até então conhecidas: energia muscular, eólica e hidráulica; 3) a melhoria marcante na obtenção e trabalho de novas matérias-primas, em particular os minerais, que deram impulso à metalurgia e à indústria química" 8 .

Com esta estruturação, fundamentada no conhecimento científico transformado em aplicações industriais, pode-se afirmar que a sociedade humana iniciou seu processo de desenvolvimento industrial, caracterizando-o como uma estrutura econômica baseada na aplicação de conceitos de acumulação capitalista no qual se buscava o progresso técnico continuado para se obter uma eficiência maior na mobilização do capital para o lucro.

Isto estabeleceu uma hierarquização do modo produtivo, provocando o surgimento de uma burguesia proprietária dos bens de produção que se estabelecia no domínio dos sistemas produtivos industriais, organizando-os e viabilizando-os através de corpos técnicos contratados que se encarregavam da 
I. Introdução

gestão do sistema produtivo constituído pelas máquinas e pelos operários que com elas interagiam.

A gestão industrial entretanto restringia-se unicamente ao que acontecia dentro dos galpões. Obter o máximo lucro com sistemas industriais organizados era a meta dos investidores. Não havia qualquer preocupação com o que estava ocorrendo fora do ambiente da fábrica. Isto acabou fazendo surgir os primeiros problemas ambientais em larga escala provocados pelo homem.

A fumaça das chaminés que se elevaram em Londres, configurando sua paisagem como a grande metrópole do início da nova economia, estavam deixando de ser um desejável símbolo do status econômico de uma grande nação. Logo, tais símbolos do dinamismo econômico advindo com o progresso da Revolução Industrial, que refletiam a intensa atividade econômica industrial inglesa, transformariam a paisagem bucólica da era vitoriana de maneira radical.

Gases e fumaça se difundiam na atmosfera, até então, intocável. Resíduos, refugos dos materiais aplicados na industrialização, entupiam rios e os canais comprometendo o escoamento das águas pluviais. Uma mal cheirosa e insalubre combinação que comprometia a vida dos fleumáticos britânicos e tornava o trabalho nas indústrias em risco de vida para os operários.

Inadequada para receber os resíduos da produção industrial, com uma precária urbanização de vielas e ruas estreitas que dificultavam a dispersão dos poluentes, a mais influente cidade do mundo ocidental do século XVIII foi a primeira a perceber os efeitos indesejáveis da industrialização.

Mas o sucesso da acumulação de riqueza pela sociedade capitalista com esta forma de produção de bens, embora a atividade industrial mostrasse problemas, continuou a induzir novos investimentos para a obtenção de procedimentos técnicos inovadores, desenvolvidos sob amparo das descobertas da ciência que passou a contar com generosos recursos para a pesquisa aplicada.

Esta estratégia dos investidores da época logo se tornou uma regra, advindo os primeiros resultados do desenvolvimento tecnológico em prol do crescimento qualitativo e quantitativo da produção industrial organizada. Assim o que antes era obra do acaso tornou-se um processo disciplinado com a aplicação de uma pesquisa racional visando aplicações práticas na indústria. 
I. Introdução

O termo Revolução Industrial passou a ser empregado para nomear este processo, ganhando um claro significado econômico e representando uma transformação rápida, fundamental e qualitativa da sociedade urbana ocidental.

É interessante observar que a substituição do trabalho humano por máquinas não era cogitada e esta situação ainda era reflexo da estrutura funcional herdada pelas antigas sociedades, onde havia uma fartura de mão-de-obra que atendia perfeitamente as necessidades de produção de bens.

Mesmo civilizações altamente criativas como a da Grécia, a qual viveu períodos de avanços demonstrados na sua arquitetura e nos planos urbanos de cidades, deteve-se apenas em pensar e estabelecer padrões para o pensamento racional ocidental, e não realizou nada expressivo com relação às aplicações da teoria mecânica desenvolvida por seus pensadores.

Talvez reflexo da exploração intensiva da mão-de-obra escrava e descartável, observa-se em textos de Heródoto ${ }^{9}$ que a palavra "arrastar"10 surge sempre quando descreve as construções da época, demonstrando que grande parte do trabalho das grandiosas construções de sua época consistia em arrastar pedras, pode-se constatar assim uma indicação de como os povos da Antigüidade eram extremamente pobres de meios técnicos, especialmente nas atividades produtivas em que o esforço humano era mais exigido.

A falta de interesse em qualquer novidade que incorporasse os conhecimentos já dimensionados da mecânica, tema em que os gregos de então avançaram significativamente na teoria, que pudesse alterar o sistema produtivo era justificado como um cuidado para não abalar a ordem social da sociedade vigente $^{11}$.

O resultado desta postura no uso de mão-de-obra intensiva foi a impossibilidade de criação de condições de acumulação na melhoria da produção redundando em nenhuma evolução tecnológica nos padrões produtivos que envolvessem trabalhos de escravos daquela época.

Esta situação ainda perduraria por muitos períodos da história da civilização ocidental, até que a otimização dos recursos humanos também se tornasse uma necessidade premente para garantir a continuidade do processo de ampliação da escala produtiva competitiva. 
I. Introdução

Isto viria ocorrer no século XVIII com o aquecimento das atividades econômicas nas colônias européias e a conseqüente demanda de mão-de-obra para ocupar os postos de trabalho nas terras colonizadas. Este fato explicaria, em parte, a motivação para a racionalização dos recursos humanos como uma das características do desenvolvimento tecnológico que caracterizou a Revolução Industrial.

Entretanto, se a tecnologia retira dos homens os mais pesados encargos físicos, antes indispensáveis para conquistar o espaço e dominar os recursos em redor de si, lança a sociedade no árido terreno da discórdia sobre as conseqüências desta conquista, impondo uma reflexão complexa sobre o custo e o benefício da aplicação das novas técnicas nas estruturas produtivas.

Percebe-se que se a técnica é o instrumento de transformação no mundo, a economia é a base racional desta transformação. $\mathrm{O}$ mundo físico tem sua mais perfeita tradução nas técnicas que surgem e é a economia que melhor o compreende, definindo como ele funciona.

Portanto a tecnologia também é um processo social no qual a técnica, um aparato técnico da indústria, do transporte ou da comunicação, não passa de um fator parcial. Não se trata da influência ou do efeito da tecnologia sobre os indivíduos, pois eles mesmos são uma parte integrante e um fator de tecnologia. E, não apenas como indivíduos que inventaram ou mantêm a maquinaria, mas também como grupos sociais que direcionam sua aplicação e utilização. A tecnologia, como modo de produção, como a totalidade dos instrumentos, dispositivos e invenções que caracteriza a era da máquina é assim, ao mesmo tempo, uma forma de organizar e perpetuar (ou modificar) as relações sociais, uma manifestação do pensamento e dos padrões de comportamento dominantes, um instrumento de controle e dominação. A técnica por si só pode promover tanto o autoritarismo quanto a liberdade, a escassez ou a abundância, o aumento ou a abolição do trabalho árduo ${ }^{12}$.

A tecnologia embute apenas uma competência técnica conquistada pela civilização tecnológica sob a qual tem sido construída há milhares de anos. Ora se acelera e se expande a todos os cantos do planeta, e, por certo, irá dominar de forma irreversível os próximos passos da civilização. 
I. Introdução

As conseqüências e efeitos das conquistas técnicas da humanidade em sua luta para o domínio das forças da natureza e o aproveitamento econômico dos recursos naturais devem ser uma preocupação permanente da sociedade organizada.

O dimensionamento abrangente dos riscos da interferência tecnológica no patrimônio natural, cultural e sócio-econômico é uma exigência vital para a inserção nos modos produtivos locais. As possibilidades, mesmo que remotas, de desestruturação de cadeias produtivas regionais devem ser avaliadas em um quadro onde estejam preservados os espaços locais de produção.

Ciência, tecnologia e informação são a base técnica da vida social atual, fazendo parte dos afazeres cotidianos dos lugares, sejam eles rurais ou urbanos $^{13}$. Portanto, apenas o conhecimento contido no meio técnico-científicoinformacional pode validar a utilização e funcionamento do espaço local como locus da produtividade global, garantindo para as regiões o encontro entre as possibilidades latentes e as oportunidades criadas pela "Nova Economia"14.

Unicamente através da capacidade de uma sociedade de conduzir sua própria experiência local pode se obter um modelo de desenvolvimento, portanto está aí a importância do entendimento do entrelaçamento do microcosmo de uma localidade com a dimensão mundial.

Este estudo releva a conexão entre conhecimento e desenvolvimento local, oferecendo uma contribuição para a compreensão de fatos que se sucedem com a globalização, processo que, mostrando-se cada vez com maior complexidade, conduz e permeia todas as atividades humanas, as quais por sua vez se renovam e buscam vencer desafios em uma cadeia sucessiva de transformações que se materializam no espaço territorial das comunidades locais. 


\section{Desenvolvimento Econômico Local}

1. Introdução, 13

2. Aspectos do Desenvolvimento Econômico Local, 18

2.1 Conceito de Local, 18

2.2 Teoria do Desenvolvimento Econômico Local, 20

2.5 Política do Desenvolvimento Econômico Local, 31

2.6 Implantação do Programa de Desenvolvimento Local, 55

2.7 Atores do Desenvolvimento Local, 69

\section{Agências de Desenvolvimento Econômico Local, 75}

3.1 Tipos de Agência de Desenvolvimento Local, 76 3.2 Estrutura da Agência de Desenvolvimento Local, 77

4. Experiências de Agências de Desenvolvimento, 79

4.1 Agências de Desenvolvimento Regional da Espanha, 79 4.2 Associação Européia de Agências de Desenvolvimento - EURADA, 82

4.3 Experiência Brasileira das ADLs em São Paulo, 90 4.4 Agência de Desenvolvimento Econômico de Ourinhos, 105 


\section{Introdução}

Desenvolvimento, entendido como um conceito, é um processo de aperfeiçoamento em relação a um conjunto de valores ou como uma atitude comparativa com respeito a tais valores, os valores sendo condições e/ou situações desejáveis pela sociedade ${ }^{1}$.

Esta definição poderia ser aplicada de uma forma abrangente como um enfoque avaliatório da condição humana, tanto individual quanto coletivamente.

Porém o termo desenvolvimento isoladamente não reflete de forma suficiente todos os campos possíveis da evolução do ser humano e de sua sociedade. Pois se em certos momentos há necessidade de dar uma ênfase maior no aspecto econômico da palavra, em outros há necessidade de focar o léxico no sentido tecnológico, em outros no cultural e assim por diante.

No princípio de desenvolvimento, certas premissas devem ser aceitas para que o termo realmente represente toda a expressão da capacidade de evolução da humanidade. Isto talvez seja possível se for levado em consideração que desenvolvimento deve refletir o progresso da sociedade em suas múltiplas dimensões e não apenas na dimensão econômica.

Também devem ser consideradas variáveis políticas, tecnológicas, sociais, ambientais e de qualidade de vida da população. Sendo algumas delas pluridimensionais, como qualidade de vida que deve englobar, entre outros índices, acesso a educação, opções culturais, condições de atendimento médico, previdência social e lazer da população. Assim não se aplica mais simplesmente índices isolados ${ }^{2}$ como renda per capita para indicar o grau de desenvolvimento de uma sociedade, pois o complexo sentido do conceito deve abranger toda a expressão do termo humanidade.

A complexidade da evolução social humana exige que, mesmo onde o termo desenvolvimento era tradicionalmente aplicado como no progresso de uma nação ou região no âmbito exclusivamente econômico, refletindo sua capacidade de criar riquezas através da mobilização de seus recursos humanos, financeiros, físicos e naturais através da geração de produtos e serviços, sofra uma ampla revisão. 
II. Desenvolvimento Econômico Local

Há muito vem se considerando que um certo grau de desenvolvimento econômico é atingido quando a base produtiva de um país ou região atinge uma expressão significativa de crescimento das atividades industriais e comerciais. Mas de que forma deve ser avaliado seu real desenvolvimento, expurgando índices meramente quantitativos e enfocando uma análise qualitativa do desenvolvimento, onde o crescimento econômico de uma sociedade estaria garantindo uma contínua melhoria de bem estar coletivo?

As inter-relações complexas alimentam um polêmica crescente sobre o papel do desenvolvimento sócio-econômico como o centro dos esforços da sociedade. Seus defensores têm justificado esta posição como uma óbvia estratégia para se alcançar o desenvolvimento como um todo. Para eles, a partir do crescimento econômico outros processos de desenvolvimentos seriam desencadeados, tais como: o político, o ambiental, o cultural, o tecnológico e todos outros que envolvem a dimensão evolucionista humana ${ }^{3}$. Seus críticos atacam a idéia de que isto seja possível, não há uma identificação tácita entre crescimento econômico e desenvolvimento. Também, como se tem visto, o crescimento econômico refletido nas atividades industriais pode levar a um mau desenvolvimento, quebrando o paradigma do progresso ${ }^{4}$.

Há uma busca permanente por postulados que respondam a configurações sócio-econonômicas de uma possível sociedade planetária que divida os mesmos princípios. Assim, por muitos anos acreditou-se no Mito do Desenvolvimento, o qual, como critica Furtado, congregando um conjunto de hipóteses unificadas, vinha sendo aceito sem discussões mais profundas, como uma fórmula capaz de universalizar o nível de consumo dos países industrializados beneficiando as nações periféricas.

De fato a dinâmica econômica, garantida pelo progresso tecnológico centralizado nos países industrializados, ao permitir um crescimento exponencial no consumo global de bens manufaturados, cada vez mais, se torna dependente dos recursos não renováveis disponíveis fora das nações produtoras.

O sistema produtivo industrial mundial, até agora, ateve-se a explorar estes recursos, através de sua capacidade econômica reprodutora, visando obter deles o máximo rendimento dos investimentos e não se comprometendo, ou se 
II. Desenvolvimento Econômico Local

assim fizesse, minimamente, em salvaguardar os recursos não reprodutíveis, pois, afinal, seria este o papel regulador dos governos nacionais.

Se por um lado os dirigentes industriais justificavam sua atitude, por muitos considerada predatória, como uma posição na defesa da economia de mercado, os economistas se restringiam a observação de que qualquer processo industrial apenas seria possível com a exploração do mundo físico.

"Alguns economistas tem se referido ao fato de que o homem não tem capacidade para criar ou destruir matéria ou energia - verdade que decorre da Primeira Lei da Termodinâmica. Contudo nenhum dele parece haver-se colocado a seguinte questão: em que então consiste um processo econômico? (...) Consideremos o processo econômico como um todo e observemo-lo estritamente do ponto de vista físico. Vê-se de imediato que se trata de um processo parcial, circunscrito por uma fronteira através do qual matéria e energia são intercambiadas com o resto do universo material. A resposta à questão em que consiste este processo é simples: ele nem produz nem consome matéria-energia; limita-se a absorver e a rejeitar matéria-energia de forma contínua. (...) Do ponto de vista da termodinâmica, a matéria-energia entra no processo econômico num estado de baixa entropia e sai dele num estado de alta entropia",5.

Entende-se que as condições futuras estariam intrinsecamente condicionadas às decisões que já haviam sido tomadas no passado, e novas situações seriam fundamentadas exclusivamente na capacidade da civilização de manipular o sistema produtivo preexistente.

Cria-se uma interdependência entre futuro e passado, onde a base material deve ser explorada com a preocupação de uma produção qualitativa que possa garantir uma baixa entropia ao final do processo.

Se até pouco, às conseqüências desta visão pouca atenção fora dada, os efeitos do processo industrial descontrolado que logo começaram a ser sentidos nas grandes metrópoles mundiais foram considerado como deseconomias de aglomeração. Níveis de poluição com índices de criminalidade mostrariam a amplitude de variáveis a serem consideradas na concentração industrial desmedida. A linearidade do crescimento econômico, uma promessa do modelo industrial tradicional, mostrava-se, então, inviável. 
II. Desenvolvimento Econômico Local

Somava-se a esta quebra no paradigma do progresso através do desenvolvimento industrial cumulativo, o surgimento, nos anos 70 , da crise no tradicional modo de produção fordista, aplicado em grandes empresas industriais, concentradas espacialmente em algumas poucas áreas urbanas, atuantes em setores como siderurgia, química, automobilística, têxtil e de plásticos, que veio provocar uma revisão do modelo organizacional até então aplicado em todos os segmentos industriais.

As mudanças ocorridas implementavam-se por meio de inovações tecnológicas, levando a modificações profundas na abordagem de fatores fundamentais para organização da produção industrial, como a produtividade e a logística. Isto determinava no planejamento das atividades industriais um entrelaçamento matricial com variáveis que deveria refletir melhor os atributos do novo modelo como: dinamicidade, complexidade e incerteza ${ }^{6}$.

A preocupação seria agora com um sistema produtivo em que as interrelações deveriam refletir a multiplicidade de respostas exigidas pelo novo modelo, e estas aplicadas pelos agentes intervenientes em cada cenário regional de forma pontual, através de micro, pequenas e médias empresas ou na criação de "clusters"7 industriais.

Com este enfoque, mediante a otimização de potencialidades locais específicas, condicionadas as condições reguladoras determinadas pela política nacional e internacional, os grandes conglomerados industriais foram estimulados a reformular suas políticas de investimento levando-os a estratégias que absorvessem o impacto das reformulações exigidas pelos novos modos operacionais onde a flexibilidade, tanto no aspecto do modo produtivo quanto na logística, seria o postulado básico para manter a competitividade e sobreviver no mercado.

Ocorre, então, uma ruptura com o modelo clássico de organização industrial centralizada em áreas urbanas de alta densidade, com a descentralização produtiva abrindo novas perspectivas de desenvolvimento para as regiões periféricas, até então praticamente ${ }^{8}$ marginalizadas do processo de desenvolvimento industrial. 
II. Desenvolvimento Econômico Local

O desafio para a sociedade global é operar esta transformação do desenvolvimento industrial na atmosfera das localidades, sem que essas percam as oportunidades para seus crescimentos econômicos e sem que aquela perca a esperança de um desenvolvimento qualificado, equalitário e equilibrado. 
II. Desenvolvimento Econômico Local

\section{Aspectos do Desenvolvimento Econômico Local}

Com as mudanças estruturais verificadas no modelo produtivo industrial, a abordagem do desenvolvimento econômico fundamentado em localidades representou uma possibilidade efetiva para atividades dirigidas ao desenvolvimento econômico local, graças às perspectivas que a mobilidade dos investimentos nos setores produtivos trouxeram às economias regionais.

O local ganhou um status estratégico nas economias das nações, alçando uma importância vital no tecido econômico, devido às oportunidades decorrentes da reestruturação do modo produtivo industrial e relocação das infraestruturas produtivas determinada pela descentralização das plantas industriais flexíveis.

Mas, afinal, qual é o significado do termo local, e até onde ele poderia ser aplicado sem perder a essência de sua acepção no contexto das teorias econômicas?

\subsection{Conceito de Local}

Sengenberger (1993), ao apontar a emergência da economia local, na forma de uma rede de locais para os grandes conglomerados, onde seria essencial tanto a base industrial de pequenas empresas fornecedoras quanto a institucional das sociedades locais, discorre sobre o sentido do local como definição de uma região em oposição ao termo nacional ou internacional. Ele vai mais além, dizendo que não há possibilidade de entende-lo precisamente, pois, um país como a Espanha ou França, pode ser visto como local quando abordado no contexto do mercado comum europeu. Em sua abordagem como foco do desenvolvimento econômico regional, o vocábulo "local" deveria ser entendido como pertinente a uma determinada área, espacial ou administrativa, compreendendo um bairro, uma vizinhança, um município ou um conjunto destes.

O termo local intercambiado com regional é usado por Blakely (1994) para se referir a uma área geográfica composta por um grupo de autoridades governamentais locais e/ou regionais que dividem uma base econômica comum e 
II. Desenvolvimento Econômico Local

são suficientemente próximas para atuarem juntas permitindo que os moradores da área dividam entre si empregos, recreação e compras.

Martin (1996) propõe que o território "local" seja visto como uma configuração de um espaço pluridimensional para a convivência e o emprego, com identidade social e histórica e como uma comunidade humana para a promoção do desenvolvimento e de uma vida melhor.

Mas o que seriam estas pluridimensões do espaço local?

Santos (1994) considera que, em oposição à dimensão mundial que é o mercado com suas organizações e instituições supranacionais, como as universidades mundiais, igrejas dissolventes, cujo resultado é a fragmentação, promove-se o surgimento da dimensão fragmentada que ocorre na tribo - união dos homens por suas semelhanças - e no lugar - união dos homens pela cooperação na diferença. Visto assim, lugar tanto pode ser o espaço geográfico chamado Ngoro Karabad como Los Angeles.

Nesta visão de Santos pode-se definir o lugar como a extensão do acontecimento homogêneo ou do acontecimento solidário e que se caracteriza por dois gêneros de constituições: uma é a própria configuração territorial, outra é a norma, a organização, os regimes de regulação. Desta forma, o lugar e a região não são mais o fruto de uma solidariedade orgânica, mas de uma solidariedade regulada ou organizacional.

Acredita Santos que a base da transformação do mapa mundial pode estar no movimento de transformação que ocorre no local onde o espaço acolhe o novo, mas guarda o vigor de sua particular herança material e cultural. Com suas características intrínsecas o local espera, tranqüilo, mas, vigilante, a ocasião e a possibilidade de reagir. Assim, fundamenta-se a ação reativa no espaço compartilhado pelo cotidiano: o local. Aonde não importa o tamanho nem a distância, meras contingências impostas pela organização territorial. Aliás, ali a única escala é o tempo.

Privilegiando a natureza transformadora do termo local, Santos afirma: "Por meio do lugar e do cotidiano, o tempo e o espaço, que contêm a variedade das coisas e ações, também incluem a multiplicidade infinita das perspectivas". 
II. Desenvolvimento Econômico Local

O território existe com uma personalidade própria. É o local, com suas dotações naturais e humanas, as suas instituições, a sua atmosfera particular ${ }^{1}$.

Pode-se entender, como forma operacional, também o sentido de "local" "como um entorno eco-sócio-territorial (município, região) onde, aproveitando-se as vantagens competitivas (vocação econômica, projetos potencialmente estruturantes, capital social, etc.), busca-se a partir do econômico construir as múltiplas dimensões do desenvolvimento integrado (social, político, ambiental, cultural, tecnológico e institucional)"2.

Como se vê, o termo "local" quando devidamente aplicado em desenvolvimento não possui uma única especificação nem um único nível, ele se compõe de um complexo sistema unificado identificando em determinada área, instituições e atores, os quais dividem ou acumulam responsabilidades no mesmo espaço geográfico.

\subsection{Teoria do Desenvolvimento Econômico Local}

Desenvolvimento econômico local não possui propriamente uma teoria $^{3}$ para embasar sua aplicação mas, sim, uma série de percepções e conceitos extraídos das experiências desencadeadas em várias regiões do mundo. Os fundamentos e conceitos que justificam sua aplicação, vêm das práticas adotadas, que confirmam premissas, registrando resultados positivos, baseados em indicadores ${ }^{4}$ como: empregos industriais, valores industriais agregados, empregos no comércio, vendas do comércio, empregos em serviços e receita de serviços.

"Quanto a uma Teoria do Desenvolvimento Econômico Local ainda é cedo demais para isto", afirma Blakely. Ele se propôs a apenas esboçar o que deveria ser uma teoria sintética para desenvolvimento econômico local através de uma síntese e reformulação de algumas idéias existentes nas teorias econômicas tradicionais. Servindo para a reflexão e a ação no contexto do desenvolvimento econômico local, o pesquisador faz considerações sobre alguns fundamentos de teoria econômica como:

1. Emprego - no modelo neoclássico baixos salários e custos menores são suficientes para criar empregos. Em desenvolvimento econômico local a comunidade deve aperfeiçoar seus recursos 
II. Desenvolvimento Econômico Local

humanos e utilizar/maximizar a base de recursos naturais e institucionais para criar oportunidades de emprego;

2. Base de Desenvolvimento - os modelos de base de desenvolvimento repousam em um enfoque setorial para desenvolvimento econômico não importando onde ele se dá. Em desenvolvimento econômico local a premissa é que a direção do desenvolvimento econômico é uma escolha consciente da comunidade que irá estruturar a base de desenvolvimento da localidade;

3. Valor da Localização - a visão tradicional é que as facilidades de transporte e o mercado determinam a viabilidade econômica de uma comunidade para o desenvolvimento. $\mathrm{O}$ modelo em desenvolvimento econômico local trabalha com novos fatores locacionais como: ambiente social e natural, facilidades para recreação e lazer, instituições sociais, políticas, educacionais e outros de natureza regional que estimulam a economia local através de um clima convidativo e favorável aos negócios;

4. Recursos do Conhecimento - a economia tradicional baseada em produtos seriados ${ }^{5}$ não exigia grandes recursos de pesquisa quanto a do "conhecimento intensivo", isto porque a informação na economia moderna se tornou ela mesmo um produto. Os recursos intelectuais de uma região são a mão-de-obra essencial na Pesquisa \& Desenvolvimento para a inovação industrial, fator fundamental para a maior parte das indústrias.

Resumiu Blakely, esta proposição, em um quadro: 
II. Desenvolvimento Econômico Local

\begin{tabular}{|l|l|l|}
\hline \multicolumn{2}{|c|}{ Quadro 1 } \\
\hline \multicolumn{2}{|c|}{ Idéias para Teoria de Desenvolvimento Econômico Local } \\
\hline Componente & Conceito Antigo & Novo Conceito \\
\hline Emprego & $\begin{array}{l}\text { Mais firmas = mais } \\
\text { emprego }\end{array}$ & $\begin{array}{l}\text { Firmas que trazem } \\
\text { empregos de qualidade de } \\
\text { acordo com o perfil da } \\
\text { população local }\end{array}$ \\
\hline Base de Desenvolvimento & $\begin{array}{l}\text { Construindo setores } \\
\text { econômicos }\end{array}$ & $\begin{array}{l}\text { Construindo novas } \\
\text { instituições econômicas }\end{array}$ \\
\hline Valor da Localização & $\begin{array}{l}\text { Vantagem comparativa } \\
\text { baseada em valores } \\
\text { físicos }\end{array}$ & $\begin{array}{l}\text { Vantagem comparativa } \\
\text { baseada em ambiente de } \\
\text { qualidade }\end{array}$ \\
\hline Recurso do Conhecimento & $\begin{array}{l}\text { Força de trabalho } \\
\text { disponível }\end{array}$ & $\begin{array}{l}\text { Conhecimento como } \\
\text { propulsor econômico }\end{array}$ \\
\hline
\end{tabular}

Fonte: Blakely (1994)

Concluiu Blakely que "este novo sistema conceitual é ainda emergente para servir como parâmetro para desenvolvimento econômico local. Ele não desfruta de status para tanto. O princípio básico deste sistema sugere que desenvolvimento econômico local é um processo que enfatiza o uso pleno dos recursos humanos e naturais para gerar emprego e criar riqueza em uma determinada localidade".

\subsection{Desenvolvimento Endógeno}

Entendido como um processo, a característica central do desenvolvimento econômico baseado localmente está na ênfase de política do desenvolvimento endógeno, no qual utiliza-se o potencial local de recursos humanos, institucionais e físicos para se atingir as metas desejadas e estabelecidas no âmbito do planejamento.

Uma definição do conceito de desenvolvimento endógeno poderia ser a que estabelece que este tipo de desenvolvimento é iniciado e organizado de dentro para fora das localidades, conferindo mobilização aos atores locais para extrair o máximo através da otimização dos recursos de capital, de trabalho e de instituições locais tanto quanto de infra-estruturas físicas de uma determinada área, em vez de esperar ou tentar atrair empresas e investimentos externos para impulsionar o crescimento econômico local e gerar empregos ${ }^{6}$. 
II. Desenvolvimento Econômico Local

A expressão "crescimento endógeno", cunhada por economistas nos anos 80 , procurou enfatizar a importância do sistema econômico nacional no desenvolvimento econômico de uma determinada região, minimizando o poder de forças impostas ao país de "fora para dentro", em oposição ao conceito do crescimento neoclássico tradicional.

Quando aplicado ao panorama regional de desenvolvimento, surgiu a perspectiva de identificar as possíveis razões para explicar porque certas regiões crescem segundo ritmos e estilos diferentes, sem obedecer a mudanças tecnológicas exógenas, ou a outros fatores produtivos, como a estruturação do trabalho.

Com base em análise empíricas, estudiosos ${ }^{7}$ concluíram que fatores, até então considerados exógenos nos modelos econômicos tradicionais, haviam passado a condição de endógenos e explicavam o crescimento regional diferenciado entre regiões de um mesmo país e sistema econômico. Desta maneira, capital humano, conhecimento, informação, pesquisa e desenvolvimento, instituições passaram a ser considerados como endógenos, explicando-se no próprio modelo de desenvolvimento regional que criavam e alimentavam.

O eixo da estratégia de desenvolvimento endógeno é a chamada sociedade organizada, onde, as iniciativas de desenvolvimento local fundamentam-se na utilização eficaz de recursos endógenos (capital social, vantagens locacionais, educação, capacitação) que dependam menos do respaldo político-administrativo por parte das instâncias da administração pública central. Estas, como trajetória do desenvolvimento tradicional ainda continuam direcionadas para dar suporte ao padrão "fordista" de produção baseado em parques industriais, economias de aglomeração, consumo de massa e gestão hierarquizada do trabalho, que acabam por condicionar o desenvolvimento regional às estratégias dos organizações nacionais e multinacionais detentoras do capital produtivo ou financeiro.

O desenvolvimento endógeno resgata a política no âmbito local, restabelecendo o conceito de governança, em que é possível para as comunidades reconhecer as suas capacidades de autodeterminação para circuitos regionais de obtenção de excedentes econômicos, como é o caso da pequena produção rural, microempresas urbanas, o setor informal e as pequenas e médias empresas em 
II. Desenvolvimento Econômico Local

geral que produzem preferencialmente para os mercados locais, sem deixar de interagir com as economias regionais.

Pode-se pensar no desenvolvimento endógeno, como uma forma eficaz de mobilizar recursos locais para se recriar um entorno institucional, político e cultural que fomente atividades produtivas e de geração de empregos em nível local, aproveitando as vantagens competitivas da integração dos mercados e dos circuitos regionais.

Lipietz (1994) afirma que há no desenvolvimento endógeno um rompimento radical com o estruturalismo global e também com teorias espaciais onde etapas de desenvolvimento urbano se sucedem, em estágios classificados como pré-industrial (primário), industrial (secundário) e pós-industrial (terciário ou quaternário). Segundo ele, a relação entre o global e o local quebra a hierarquia dos lugares centrais, onde há o pressuposto de um espaço homogêneo. As regiões não são homogêneas, portanto pode-se creditar a esta condição a capacidade de sucesso de uma economia flexível, onde o crescimento das atividades econômicas deverá depender essencialmente das dinâmicas regionais.

Há de se cuidar, segundo Haddad (s/d), de diferenciar os termos crescimento econômico e desenvolvimento econômico, segundo ele:

O primeiro reflete a condição de uma certa região, sob um determinado ambiente político e econômico, de elevar seus níveis de produção, de renda e emprego de forma a superar a capacidade de absorção destes níveis pela população regional, acumulando reservas potenciais para comercialização externa e investimento.

O segundo depende da habilidade local de estruturar sua organização institucional e social, de forma a obter autonomia para a tomada de decisões obtendo competência para reter e reinvestir o excedente econômico gerado pelo processo de crescimento econômico regional.

Haddad (s/d) procura, ainda, distinguir as vantagens competitivas dinâmicas específicas de cada região daquelas que ela considera espúrias "que não se sustentam a longo prazo, por estarem fundamentadas em incentivos fiscais e financeiros recorrentes (que podem desaparecer a partir das exigências dominantes da estabilização econômica, ou se tornarem ubíquos através da guerra 
II. Desenvolvimento Econômico Local

fiscal entre Estados e Municípios), no uso predatório dos recursos naturais do ecossistema (que podem se restringir ou por limitações físicas ou por legislação ambiental), na sobreexploração da força de trabalho (que pode encontrar resistências políticas ou legais com o avanço da redemocratização), ou na informalidade e na clandestinidade de suas operações (que podem chocar-se com a modernização dos sistemas tributários e previdenciário)”.

Vê-se que a competência regional para o desenvolvimento econômico local deve ser sustentada pela sua capacidade intrínseca de promover as vantagens locais para uso dos recursos humanos e materiais, sem degradar a sociedade, o meio ambiente e a qualidade de vida, e sem comprometer a estrutura organizacional e política que administra o espaço territorial.

\subsection{Ativos Locais para o Desenvolvimento}

Como foi apontado, as premissas básicas para o desenvolvimento econômico local: a formação de capital, físico e humano, com progresso tecnológico; a adequação de postura social e institucional da localidade; e sua capacidade de articulação podem ser considerados como os ativos locais para o desenvolvimento local. Seriam estes ativos os recursos intrínsecos locais resultados da participação efetiva da comunidade no processo de desenvolvimento da localidade.

Esta visão tem sido compartilhada pelas empresas que vêm na qualidade e capacidade do desenvolvimento econômico de uma localidade também a possibilidade de criar condições favoráveis ao sucesso de seus negócios.

Em levantamentos realizados na Inglaterra, Bennet (1988) constatou que as empresas têm maior chance de prosperar quando:

a) localizam-se em áreas florescentes, onde as pessoas desejem morar, trabalhar e investir de bom grado, em que o ambiente e as estruturas sejam seguros e desfrutáveis;

b) as economias regionais emergentes se constituem em mercados significativos para a empresa; 
II. Desenvolvimento Econômico Local

c) não há risco de degradação ambiental que possa provocar depreciação imobiliária e deterioração de vizinhança;

d) há investimento a fundo perdido em equipamentos comunitários;

e) existe participação da empresa em negócios regionais, criando sinergia para as empresas locais e abrindo novos mercados locais;

f) ocorre um recuperação da economia local com efeito multiplicador em atividades secundárias, como, por exemplo, o setor de transportes de cargas;

g) contrata-se mão-de-obra local e dá-se treinamento e formação profissional, criando-se um adequado clima de convivência trabalhista;

h) participa-se do mundo de negócios local, estimula-se a vida comunitária, através de criação de escolas e preservação ambiental, contribuindo para a manutenção de boas relações com a região, amenizando as tensões sociais, decorrentes de mudanças estruturais econômicas, facilitando as relações de trabalho dentro do ambiente da empresa e desenvolvendo a fidelidade do empregado com a empresa.

Está evidente, então, que o interesse das empresas no desenvolvimento econômico local, antes que um simples posicionamento de marketing institucional tem a preocupação de manter sua competitividade no mercado. Além disso, esta posição, tem uma certa coerência com o que talvez seja o principal papel da responsabilidade social empresarial: manter o sistema produtivo em operação e garantir, assim, a atividade econômica direta e indireta nas localidades.

Percebeu-se que a crença generalizada de que a queda ou redução de barreiras regulatórias entre as nações e o avanço na tecnologia de transportes iria beneficiar regiões até então desfavorecidas não abalava a importância da questão locacional nos processos decisórios de novos empreendimento.

Mesmo considerando esta perspectiva otimista para as localidades, devem ser considerados, como vantagens competitivas para estes locais, outros 
II. Desenvolvimento Econômico Local

fatores locacionais que são vitais para a decisão de investimentos industriais como: "presença de trabalhadores qualificados em permanente processo de renovação de conhecimentos; um núcleo de consumidores com nível de exigências e de preferências à frente das necessidades de consumidores de outras localidades; uma massa crítica de fornecedores locais de componentes e de serviços terciários e quaternários que contribuam significativamente para a melhoria da qualidade dos produtos e da eficiência dos processos de produção"8.

Ainda no planejamento da logística industrial, com o avanço das ciências e da tecnologia de informações, um outro aspecto relevante é o fluxo de comunicações de cuja agilidade irá depender a dinâmica empresarial. Hoje, a infra-estrutura de telecomunicações está ligada diretamente à capacidade da empresa de acessar dados sobre produtos e clientes com destreza assegurando a sua competitividade no mercado em que atua.

Manzagol (1980), ao formular propostas para uma estratégia no processo decisório logístico, propôs duas classes de fatores: os visíveis e os invisíveis. Os visíveis seriam aqueles que tratam da mercadoria diretamente, como os insumos, e os invisíveis aqueles que viabilizam indiretamente, a produção, como o capital e a informação. Estes fatores formam uma rede de fluxos centrada nos pontos de apoio constituídos pelos aparelhos de produção e administração.

Deve-se observar que "esta definição é restrita na medida em que não abrange todo o impacto da indústria sobre as áreas que ela prospecta para seu abastecimento em bens e serviços e para o escoamento de seus produtos, e que organiza para as necessidades de sua força de trabalho", como uma capacidade parcial de decisão, enfocando a logística no âmbito do ciclo produtivo da indústria no momento da análise.

Para corrigir esta distorção, parte-se de uma análise centrada no ciclo de vida do produto, como Manzagol apontou. Nesta abordagem é possível verificar a importância de fatores diversos de acordo com o grau de maturação do ciclo produtivo, pois todo produto conhece um ciclo produtivo vital e em cada uma de suas fases (lançamento, crescimento e maturidade) as necessidades são distintas e as relações da indústria com a região variam de acordo com a posição no ciclo, como pode-se observar no quadro seguinte. 


\begin{tabular}{|l|c|c|c|}
\hline \multicolumn{4}{|c|}{ Quadro 2} \\
\hline \multicolumn{3}{|c|}{ Importância de Fatores Regionais na Logística Industrial } \\
\hline Fatores Regionais & Novo & Em crescimento & Maduro \\
\cline { 2 - 4 } & Média & Forte & Fraca \\
\hline Gerenciamento & Forte & Média & Fraca \\
\hline Tecnologia & Forte & Média & Fraca \\
\hline Economias Externas & Fraca & Forte & Forte \\
\hline Capital & Fraca & Média & Forte \\
\hline $\begin{array}{l}\text { Mão-de-obra Não } \\
\text { Qualificada }\end{array}$ & & & \\
\hline
\end{tabular}

Fonte: Manzagol (1980)

Neste quadro, Manzagol chama a atenção por ter utilizado a inversão de posição estratégica quanto a ocupação da mão-de-obra não qualificada, priorizada em detrimento da qualificada, normalmente foco das atenções dos estrategistas industriais. Deve-se notar que ele também diferencia economias externas de capital, o primeiro fator evidencia a necessidade de investimento em desenvolvimento de produto enquanto o segundo destaca a importância de recursos para a produção, o que é necessário para os investimentos operacionais em máquinas, equipamentos e qualificação da mão-de-obra.

Premus (1984) reconhece que a questão logística do ponto de vista de empresas de alta tecnologia depende do meio regional favorável para a incubação visando desenvolvimento de seus projetos e, assim, elas preferem locais com capacidade de inovação tecnológica.

É possível, segundo Premus, a atração de empresas tecnológicas para cidades longe dos grandes centros urbanos e/ou fora dos eixos industriais, sendo esta uma questão superável pelas condições favoráveis ao desenvolvimento de produtos de alta tecnologia.

Ele confirmou esta hipótese através dos resultados de sua pesquisa em companhias de alta tecnologia, onde os dirigentes responderam às perguntas de forma qualitativa, indicando para cada um dos fatores o grau de significância ${ }^{10}$ na decisão locacional. 
II. Desenvolvimento Econômico Local

\begin{tabular}{|c|c|}
\hline \multicolumn{2}{|c|}{ Quadro 3} \\
\hline \multirow{2}{*}{\multicolumn{2}{|c|}{$\begin{array}{l}\text { Importância de Atributos Regionais na Logística Industrial de Empresas de } \\
\text { Alta Tecnologia }\end{array}$}} \\
\hline & \\
\hline Atributos Regionais & Significância \\
\hline Viabilidade de Mão-de-Obra Qualificada & $89,3 \%$ \\
\hline Custos da Mão-de-Obra & $72,2 \%$ \\
\hline Tributação Fiscal Local & $67,2 \%$ \\
\hline Instituições Acadêmicas & $58,7 \%$ \\
\hline Custo de Vida & $58,5 \%$ \\
\hline Transporte & $58,4 \%$ \\
\hline Acesso ao Mercado & $58,1 \%$ \\
\hline Prática Regulatória Local & $49,0 \%$ \\
\hline Custos e Viabilidade de Energia & $41,4 \%$ \\
\hline Vida Cultural & $36,8 \%$ \\
\hline Clima & $35,8 \%$ \\
\hline Acesso a Recursos Materiais & $27,6 \%$ \\
\hline
\end{tabular}

Fonte: Premus (1984)

Verifica-se, no quadro acima, que o mais importante atributo no nível regional ou local é aquele que representa a viabilidade da oferta de mão-de-obra qualificada como cientistas, engenheiros e tecnológos. Isto se deve à importância que ela tem para os departamentos de Pesquisa \& Desenvolvimento, sendo vital na sobrevivência das empresas que têm alta tecnologia como objetivo produtivo, o pessoal de qualificação máxima.

Detalhando melhor a pesquisa, o pesquisador verificou alguns fatores relevantes na visão dos executivos quando escolhiam definitivamente as regiões em que iriam localizar seus empreendimento de alta tecnologia:

\begin{tabular}{|l|l|}
\hline \multicolumn{2}{|c|}{ Quadro 4 } \\
\hline \multicolumn{2}{|c|}{ Fatores Influentes na Escolha de Regiões } \\
por Empresas de Alta Tecnologia \\
\hline Fatores & Significância \\
\hline
\end{tabular}


II. Desenvolvimento Econômico Local

\begin{tabular}{|l|c|}
\hline Viabilidade de Mão-de-Obra: & $96,1 \%$ \\
Qualificada & $88,1 \%$ \\
Não Qualificada & $52,4 \%$ \\
Técnica & $96,1 \%$ \\
Profissional & $87,3 \%$ \\
\hline Tributação de impostos estadual e/ou local & $85,5 \%$ \\
\hline Atitude da comunidade com relação a negócios & $81,9 \%$ \\
\hline Custo de imóveis e construções & $78,8 \%$ \\
\hline Transporte de qualidade para os trabalhadores & $76,1 \%$ \\
\hline Área ampla para futuras expansões & $75,4 \%$ \\
\hline Proximidade com boas escolas & $70,8 \%$ \\
\hline Proximidade para lazer e cultura & $61,1 \%$ \\
\hline Facilidades de transporte para materiais/produtos & $56,9 \%$ \\
\hline Proximidade ao mercado consumidor & $46,8 \%$ \\
\hline Disponibilidade de fornecimento de energia & $45,6 \%$ \\
\hline Proximidade aos recursos materiais e fornecedores & $35,7 \%$ \\
\hline Fornecimento de água & $35,3 \%$ \\
\hline Adequada infra-estrutura para tratamento de resíduos & $26,4 \%$ \\
\hline
\end{tabular}

Fonte: Premus (1984)

O resultado da pesquisa de Premus é muito interessante, pois, além de destacar o que é importante para as companhias de alta tecnologia, ele também aponta na direção do que não é importante para este tipo de empresa: se por um lado os executivos destas companhias de ponta dão ênfase aos aspectos econômicos, sociais e institucionais da região alvo da localização de suas plantas industriais, eles não dão muita importância aos fatores verdes como energia, clima, água, disposição de resíduos e recursos materiais.

Pode-se concluir desta pesquisa, que os atributos invisíveis da comunidade, de acordo com o termo sugerido por Manzagol, são altamente relevantes pois, deles depende o conhecimento e seu desenvolvimento que irá desembocar na criatividade, o que é determinante na locação dos empreendimentos de alta tecnologia para os quais a inovação é um fator de vitalidade e sobrevivência.

Ressalta-se, então, o papel do setor político, pois se um dia chegou-se a pensar no fim do planejamento do espaço público, evidencia-se sua importância na administração otimizada do recurso territorial. "Um bom ambiente, como diriam os economistas, é um bem rentavelmente elástico: à medida que o povo e as sociedades em geral enriquecem exigem proporcionalmente mais e mais do ambiente onde vivem"11. O território, com todas suas características intrínsecas, 
II. Desenvolvimento Econômico Local

materiais e imateriais, servindo como espaço econômico das atividades produtivas, deixa então de ser um mero suporte físico e torna-se um agente ativo do desenvolvimento.

\subsection{Política do Desenvolvimento Econômico Local}

\subsubsection{Governança}

Emergem, na configuração do desenvolvimento local, diz Lipietz, algumas questões chaves para regular o uso do espaço regional pelas atividades econômicas que abandonam o modelo de desenvolvimento excessivamente organizado, cujos fundamentos encontravam-se baseados no modo de produção do fordismo e de sua planificação racionalizada:

A primeira é que a materialização das atividades no espaço, a paisagem econômica no sentido próprio da palavra, é a primeira das formas de regulação;

A segunda é que esta materialização provém espontaneamente de iniciativas concorrentes dos próprios agentes destas atividades;

A terceira é que o Estado abandona sua função estruturante na produção, na reprodução social e no espaço.

A conseqüência principal, oriunda de uma quebra da hierarquia política e da reorganização industrial em rede ${ }^{12}$, é uma desintegração vertical da regulação. Em se tratando de regiões urbanas, "a atenção vai focalizar sobre as formas de regulação intermediárias entre a materialidade da aglomeração urbana e o governo, a legislação e a ação do Estado. Eleva-se, então, um conceito oriundo da língua inglesa: governance. Trata-se de todas as formas de regulação que não são nem os mercantis nem do Estado. Para parafrasear a definição de Gramsci (o Estado $=$ sociedade civil + sociedade política $)$, a governança é a sociedade civil menos o mercado. Mas, temos de acrescentar à sociedade política local, os notáveis, as municipalidades"13.

Segundo Lipietz, isto sugere um retorno triunfal da política. E para confirmar este fato, cita considerações de Mick Dunford sobre a dimensão política do desenvolvimento local: "independentemente de qualquer discussão sobre a 
II. Desenvolvimento Econômico Local

forma, a natureza, a dimensão ética ou social dos modos de governança, o simples fatos de que as redes funcionam a la governança, tanto ou mais que sob leis de mercado, é suficiente para refutar as pretensões neo liberais".

A adoção de uma política de desenvolvimento local também irá depender de uma articulação inter-regional onde o papel político do governo é fundamental. Verifica-se, desta forma, que ainda está longe a tão falada obsolescência do Estado. De fato isto se mostra uma falácia, como apontou Hélio Zilberstajn $^{14}$. Ele diz que há uma certa desregulamentação de mercados, de alguns segmentos do sistema financeiro, programas importantes de privatização, etc. Mas, a participação do Estado na economia, que já vinha crescendo expressivamente e de forma mais ou menos contínua ao longo do século $\mathrm{XX}$, continuou a aumentar no período mais recente, a despeito da preponderância ideológica do pensamento "neo liberal".

\subsubsection{Papel do Setor Público}

Distingui-se a importância de uma dinâmica governança na política de desenvolvimento local, pois será ela que irá definir o modelo de desenvolvimento, que emerge do bloco sócio-econômico territorial, determinando o tipo e o funcionamento da rede industrial e o perfil da mão-de-obra que irá demandar. Há de se cuidar da política de desenvolvimento regional, pois uma governança pouco dinâmica, dependente de uma política central de proteção sistemática dos interesses locais podem sufocar a capacidade produtiva local, aponta Lipietz.

Berman \& Martin (1992) trazem à discussão um original enfoque: o papel da inovação no setor público para a condução do processo de desenvolvimento econômico local.

Eles analisaram levantamentos ${ }^{15}$ realizados nos EUA pela Corporation for Enterprise Development (CED) que considerou as seguintes medidas para avaliar a capacitação dos governos locais frente a complexidade da economia globalizada: 
II. Desenvolvimento Econômico Local

a. condução de atividades de desenvolvimento econômico, coletando e analisando dados, desenvolvendo e revendo políticas e coordenando esforços;

b. oferta consistente de serviços públicos e investimentos, obtida através de sistema eficiente de taxação de impostos;

c. regulação financeira formulada dentro dos limites do sistema financeiro do estado, garantindo aos investidores privados proteção contra o risco e outras situações adversas, necessárias para mobilizar o capital;

d. ambiente favorável ao desenvolvimento tecnológico e empresarial através de projetos que ligam os centros de pesquisa e universidades às empresas, programas para transferência tecnológica e facilidades para o desenvolvimento de pequenas empresas;

e. fundos de investimentos para manutenção e construção de infraestrutura;

f. fundos de investimento para qualificação de recursos humanos, como por exemplo: educação pública em todos os níveis e programas de treinamento de trabalhadores; e

g. projetos de ajuda a comunidades carentes através de programas de desenvolvimento econômico comunitário e outras iniciativas.

Os pesquisadores, a partir do extenso rol de indicadores, reorganizaram-no em duas categorias de variáveis:

a. aquelas que refletiam condições culturais, sociais e econômicas; e

b. aquelas que refletiam condições políticas, tais como: participação, condições de sistemas partidários e grupos de interesse, e capacidade e liderança governamental.

O primeiro conjunto, chamado de variáveis ambientais, e o segundo conjunto, chamado de variáveis políticas, determinam a capacidade de inovação governamental, considerada como um produto dos dois tipos de variável, observando-se que as variáveis ambientais afetam direta e indiretamente a 
II. Desenvolvimento Econômico Local

capacidade de inovação por causa da sua relação com as variáveis políticas. Significa dizer que as ações políticas inovadoras irão depender da capacitação governamental de gerenciar as condições locais para inovação.

Berman \& Martin (1992) relevam a importância das condições locais culturais, econômicas e sociais para a efetiva capacidade de inovação governamental em absorver os novos paradigmas para o desenvolvimento econômico. Avalizando suas conclusões, citam Osborne ${ }^{16}$ que afirma: "O papel principal do governo é nutrir os elementos que viabilizam a inovação, tornando-a possível: vibrante infra-estrutura intelectual; força de trabalho educada e qualificada; atraente qualidade de vida; ambiente de negócios; oferta de capital de risco; mercado receptivo para novos produtos e processos; compromisso com a modernização industrial; cultura para a industrialização com flexibilidade e cooperação; e sistema social que apoia a inovação e a diversidade".

\subsubsection{O Estado Empreendedor}

Abordando a questão estrutural política, Benington \& Geddes (1992) notaram que por trás da evolução no enfoque do desenvolvimento econômico local notado entre as primeiras experiências realizadas nos anos 70 e 80 e as em curso nos anos 90, estavam as alterações nos modos de produção fordista para pós-fordista e a integração estratégica empresarial provocada pelo crescente processo de adoção mundial do modelo político neo liberal.

Eles identificaram uma revisão de posições das tradicionais agências governamentais de desenvolvimento européias criadas no pós-guerra por conta das mudanças de paradigma na nova economia globalizada, confrontando-as com um novo conjunto de desafios que colocavam as localidades em um cenário inteiramente desconhecido.

Além disso, apontaram Benington \& Geddes que iniciativas de cunho

privado e essencialmente empresarial foram introduzidas no âmbito da administração pública, primeiramente nos países de onde surgiu a teoria econômica neo liberal, como os EUA e Inglaterra, e depois pelos países da Comunidade Européia e nos demais países do Reino Unido da Grã-Bretanha.

Uma das conseqüências desta onda neo liberal foi uma série de privatizações dos serviços públicos no mundo, consubstanciando ações de 
II. Desenvolvimento Econômico Local

reorganização das atividades econômicas, trazendo uma uniformidade de idéias sobre os objetivos políticos gerais no campo econômico mundial.

Segundo Clarke \& Gaile (1992) as novas estratégias políticas locais se destacam das políticas tradicionais por serem desenvolvidas para minimizar riscos para investimentos de recursos privados e públicos externos, tendo orientações voltadas às economias de mercado.

Duas características distinguem estas estratégias baseadas em conceitos de mercado dos enfoques mais tradicionais:

1. o foco de investidores privados em processos que agregam valor e,

2. o papel de risco do setor público nos investimentos.

As políticas públicas locais passaram a ser centradas em novos enfoques estimulando o desenvolvimento de empreendimentos nas comunidades mais do que subsidiando decisões locacionais de empresas ou estratégias de geração de emprego nas regiões, destacam Clarke \& Gaile.

Nos níveis locais, regionais e nacionais, ações para desenvolvimento ocorrem através de agentes que representam interesses coletivos da comunidade ou setoriais ou de grupos particulares que agem e intervêm diretamente no espaço regional, introduzindo um relacionamento entre os atores locais no qual os múltiplos objetivos se associam para intervenções coletivas não-governamentais abrangendo bens públicos e privados ${ }^{17}$.

Dessa maneira, surgem diferentes possibilidades de atuação para o novo papel empreendedor do setor público como agente facilitador na promoção do desenvolvimento econômico regional e local.

Embora tenha se observado uma identificação de propósitos, “as políticas locais de desenvolvimento devem escolher a ênfase que deverá ser dada aos seus projetos de desenvolvimento econômico local. Assim, a comunidade local pode optar entre:

1. um enfoque proativo e preventivo para a indústria e para a economia local, ou um tradicional papel reativo, no qual, principalmente, as estruturas e instituições públicas corrigem 
II. Desenvolvimento Econômico Local distorções sociais provocadas pelas mudanças no perfil industrial e econômico local;

2. um compromisso de prioridades e recursos para o desenvolvimento de empresas existentes, aperfeiçoamento da qualidade de produção e capacidade tecnológica locais, ou um foco mais tradicional para atrair novas empresas e investimentos externos;

3. um envolvimento direto com assistência para as empresas locais e projetos para a geração de empregos, o qual deverá ser feito com a combinação de finanças, orientações e acompanhamento, ou um mais tradicional relacionamento direto ou indireto na forma de apoio, tanto em infra-estrutura social quanto física;

4. um comprometimento decisivo do setor público em atuar como um importante empregador, proprietário de terras, investidor, empreendedor, comprador e fornecedor de produtos e serviços e interferir na economia local, ou um estratégia que conscientemente subordina o setor público a um papel funcional das iniciativas empresariais;

5. objetivos econômicos locais ligados a criar empregos e compartilhar preocupações, ou objetivos voltados para o crescimento econômico e modernização"18.

Por trás destas opções estão, na verdade, tendências políticas, verificadas principalmente nas décadas de 70 e 80 , quando as primeiras iniciativas de desenvolvimento econômico local partiram de partidos de esquerda que estavam preocupados em promover um novo papel para o setor público diante do crescimento ideológico neo liberal, principalmente nos países europeus que enfrentavam um processo de desaceleração econômica determinado pela desativação das indústrias de setores como o siderúrgico e o têxtil, tradicionais grandes empregadores ${ }^{19}$.

Observaram, ainda, Clarke \& Gaile que alguns estrategistas governamentais erraram ao apostar em setores que perdiam a atratividade, seja pela baixa capacidade de crescimento tendo em vista a redução do mercado de 
II. Desenvolvimento Econômico Local

seus produtos seja pela inviabilidade econômica devido à competitividade internacional acirrada, o que acabaria por provocar uma descontinuidade produtiva.

Eles constataram que não perceber a amplitude da reestruturação econômica sobre as microeconomias locais foi fatal para algumas localidades que assistiram ao fechamentos de instalações industriais sem possibilidade de interferir nas decisões macroeconômicas dos grandes grupos de investimento.

As comunidades, sensíveis às transformações econômicas globais que estavam se refletindo em suas vizinhanças, notaram os pesquisadores, passaram a ver nas instituições públicas as guardiãs dos interesses coletivos frente às mudanças trazidas com a globalização. Então qual seria o papel que o setor público deveria desempenhar para não frustar as expectativas da comunidade?

Percebe-se que a nova realidade no modo de produção, reconhecido como pós-fordista, onde a produção industrial em massa cede lugar a um novo modelo de produção flexível e especializada, decreta a introdução de novos paradigmas que estão redefinindo a função do setor público como promotor do desenvolvimento econômico local.

Evidencia-se que a aceleração do desenvolvimento de novas tecnologias veio permitir uma ampla gama de possibilidades para pequenos núcleos industriais com produtos cada vez mais customizados para mercados segmentados, permitindo que as grandes empresas pudessem desconcentrar suas produções em unidades produtivas menores ou terceirizar a fabricação de seus produtos para pequenas empresas locais.

Mas até que ponto uma comunidade tem seus recursos humanos capazes de participar do processo produtivo mais especializado? Vê-se aí a importância de ser estruturado um eficiente programa de treinamento e qualificação, papel que pode ser desempenhado por um organização do setor público, ainda que na função de facilitadora das atividades educacionais.

A ampliação do uso da tecnologia da informação para a produção em série viabiliza a relocação de grandes empresas que passaram a atuar em forma de uma rede, não necessariamente localizada no mesmo país ou região. $\mathrm{O}$ modo econômico de uma empresa, desta forma, integrava-se a um tecido internacional 
II. Desenvolvimento Econômico Local

baseado em pequenas e médias empresas localizadas em diferentes regiões do planeta, fortalecendo a economia regional como um importante fator do crescimento das atividades econômicas globais.

Neste aspecto é fundamental a difusão de modernos sistemas gerenciais entre as pequenas e médias empresas locais, as quais devem interagir com as grandes que aplicam conceitos como just-in-time na organização industrial, uma infra-estrutura adequada para a operação da pequenas e médias empresas neste e em outros sistemas de produção pode ser uma iniciativa direta ou indiretamente administrada pelo setor público.

Enquanto as empresas estão na busca dos melhores locais para relocar suas produções industriais, as comunidades procuram entender e intervir neste processo de transformação de forma que suas bases produtivas locais correspondam às necessidades das indústrias. $\mathrm{O}$ papel do setor público é fundamental para que a estrutura produtiva local responda positivamente aos estímulos da "Nova Economia", especialmente nas questões de integração e cooperação que quando estimuladas possibilitam a articulação e complementaridade necessárias para integrar a cadeia produtiva de um produto industrial serial nas localidades.

Benington \& Geddes (1992) concluíram que "os governos locais devem ser considerados chave no estímulo à inovação tecnológica e na promoção institucional dos distritos industriais locais, tanto quanto na qualificação e treinamento da mão-de-obra local, além da provisão de terrenos e infra-estrutura", mas esta visão talvez ainda seja resquício de um tempo em que governos eram centralizadores o que pode impedir um envolvimento dos investidores locais, uma possibilidade que não deve ser fechada, embora tenha-se visto uma certa relutância em aplicar dinheiro em atividades tradicionalmente de retornos lentos como o mercado imobiliário, ainda mais competindo com o efervescente mercado de capital de risco oferecido pelas ações das empresas de alta tecnologia e da Internet.

De forma geral o setor público, que tem o papel chave de promover e estimular as novas formas de trabalho e produção e não permitir a marginalização de pessoas e empresas, mas, fazê-las capazes de se integrar ao mercado e aos novos processos produtivos, não vem conseguindo desempenhar a contento por 
II. Desenvolvimento Econômico Local

causa de uma visão, muitas vezes estritamente neo liberal, imposta pelo setor privado que costumeiramente busca uma produção industrial competitiva de forma predatória, desmobilizando postos de serviço e desarticulando a cooperação na base industrial existente nas regiões ${ }^{20}$.

Coelho \& Fontes (1994) refletindo sobre o papel dos governos locais no Brasil, perceberam, no início da década de 90, que "têm crescido as iniciativas de ações de combate à fome e à miséria através de políticas de geração de trabalho e renda, estimulando principalmente os municípios a apoiarem ou promoverem fóruns de desenvolvimento econômico, balcões de negócios, feiras de oportunidades, cursos de capacitação para pequenos empreendedores, fundos de apoio e outras iniciativas. Estas ações das prefeituras significam implementar um desenvolvimento humano, sustentável a longo prazo, gerando aumento de oportunidades de emprego para os grandes setores da população atualmente excluídos do mercado de trabalho, nos quais os municípios se constituem em sujeitos ou atores nesta grande tarefa".

Isso não é surpreendente, tendo em vista o fato de o desemprego se expressar mais visivelmente no nível local. São os municípios a primeira instância governamental a enfrentar as conseqüências da pobreza e da miséria: a degradação das condições de moradia, de saneamento, do meio ambiente, etc.

Tradicionalmente, os municípios e o setor público em geral têm sido uma importante fonte de empregos diretos. Agora, como se viu até aqui, há várias razões para o Estado mudar do que seria um "Estado empregador" para um "Estado empreendedor" com um perfil de "Estado gerente", abandonando a relação paternalista e clientelista com a sociedade, cuja expressão máxima é o emprego de baixa produtividade no setor público. Assim a concepção do setor público como uma fonte de empregos além de mostrar-se obsoleta, o torna inoperante e ineficiente. A eficácia do processo de desenvolvimento local é um fator vital para a confiabilidade de uma governança territorial e a visão de eficiência do setor público é peça fundamental na estruturação do desenvolvimento econômico da comunidade.

Refletindo um compromisso crescente com o privatismo, em que se destaca o crescente papel do setor privado em funções tradicionalmente ocupadas 
II. Desenvolvimento Econômico Local

pelo setor público, as políticas de desenvolvimento local repousam em "hipóteses como:

a. os governos locais devem encontrar maneiras de estimular a expansão do capital privado porque o capital privado tem o papel vital na inovação econômica urbana e desenvolvimento, incluindo a geração de emprego;

b. o melhor caminho para o governo local estimular a expansão das atividades privadas no meio urbano é formar parcerias com o setor público e usar os limitados fundos públicos para alavancar investimentos privados;

c. esforços para o desenvolvimento econômico podem e devem ter como objetivo os grupos desfavorecidos e comunidades marginalizadas;

d. recursos públicos precisam ser dirigidos para projetos que não seriam viáveis sem subsídios públicos;

e. governos locais devem concentrar esforços para desenvolvimento econômico naqueles setores que estão na vanguarda da alta tecnologia e serviços especializados pós-industriais;

f. para serem eficazes, governos locais precisam dirigir desenvolvimento econômico mais como um assunto técnico do que político;

g. programas de desenvolvimento econômico local são opções de baixo custo para os governos locais porque eles podem contar com recursos privados;

h. comunidades podem captar benefícios do investimento em desenvolvimento econômico; e

i. todos na comunidade dividirão os benefícios do desenvolvimento econômico local e os custos não estarão concentrados em nenhum segmento da população"21. 
II. Desenvolvimento Econômico Local

Barnekov \& Rich (1989) ao reverem na prática estas suposições da política de desenvolvimento econômico local, constataram que algumas delas vinham sendo encaradas com certo ceticismo, devido a considerações como:

a. programas de desenvolvimento econômico local, ao designar fundos públicos para alavancar investimentos privados freqüentemente, vêem os empreendedores privados utilizarem estes recursos para desenvolvimento de seus próprios objetivos, além de exigir dos governos locais constantes subsídios para a implementação dos projetos financiados;

b. enquanto os governos locais assumem de forma irredutível o papel de principal investidor de risco, as empresas estão livres para se mudar e relocar suas infra-estruturas produtivas para onde houver maior oferta de fundos de risco públicos;

c. agências públicas e empreendedores privados, visando conseguir recursos externos federais ou estaduais, forjam associações apenas para facilitar a captação de recursos subsidiados;

d. programas de desenvolvimento econômico voltados para as comunidades e grupos desfavorecidos são limitados por barreiras políticas;

e. programas de desenvolvimento econômico local concentrados em setores de alta tecnologia e serviços especializados pós-industriais não têm ainda comprovado um padrão consistente de eficácia como uma estratégia eficaz de geração de desenvolvimento local;

f. programas de desenvolvimento econômico local retiram as ações dos governos do debate público, reduzindo os ganhos políticos das administrações municipais e a representatividade dos governantes locais;

g. programas de desenvolvimento econômico local escondem os custos indiretos de governo local para pressionar os governos federais e estaduais na liberação de fundos para projetos de desenvolvimento, estes recursos acabam saindo de outros projetos ou investimentos públicos, como serviços e infra-estrutura; 
II. Desenvolvimento Econômico Local

h. estratégias para desenvolvimento econômico local desviam atenção e recursos do governo que estariam sendo aplicados diretamente na solução de problemas sociais;

i. comunidades nem sempre capturam os benefícios de programas de desenvolvimento econômico local porque seus resultados principais, que são os empregos e os investimentos, atravessam os limites municipais;

j. desenvolvimento econômico local não reflete os interesses da cidade como um todo e nem provê benefícios para a cidade como um todo.

Dizem os pesquisadores que a capacidade do governo municipal realizar um programa de desenvolvimento econômico baseado localmente é limitada e a visão essencialmente privativista não garante seu sucesso, mesmo com um forte compromisso com o setor privado: "o que o mercado poderia fazer bem, as localidades fazem bem e o que o mercado fez mal, ou neglicenciou, as localidades têm sido ineficientes para superar" ${ }^{22}$.

As estratégias de desenvolvimento local com estes enfoques abrangentes e complexos, ao mesmo tempo que dão às localidades capacidade de se estruturarem em suas bases produtivas, exigem das lideranças regionais uma maior capacidade de análise para que a continuidade dos projetos não sofra com eventuais erros de avaliação.

Como notaram Clarke \& Gaile, é indispensável que os instrumentos de planejamento estejam revestidos de cultura para projetos de riscos e que os planos de ação contemplem diversidades em:

- Meta, estimulando novos empreendimentos mais do que protegendo os tradicionais;

- Foco, utilizando a autoridade governamental para estruturar as oportunidades de mercado mais do que para influenciar as funções do mercado; 
II. Desenvolvimento Econômico Local

- Critério, usando critérios do mercado, como maximização das taxa de retorno, mais do que critérios políticos em estabelecer prioridades para alocação de investimentos de fundos públicos;

- Finança, alavancando recursos públicos e privados mais do que privilegiando um deles;

- Papéis, contando com parcerias público-privado efetivas em tarefas para implementar projetos de desenvolvimento econômico mais do que meramente burocráticas;

- Gerenciamento, administrando os projetos através de agências não-governamentais mais do que através de agências públicas;

- Processo de Decisão, envolvendo decisões negociadas caso-a-caso mais do que em burocráticos e padronizados processos;

- Conexões, estabelecendo relações concretas mais do que simplesmente relações contratuais baseada em direitos e obrigações.

Clarke \& Gaile, ao mesmo tempo que viram crescer o papel empreendedor dos governos locais nos EUA, notaram que as lideranças comunitárias ainda precisam lutar para superar a antiga visão paternalista que predomina dentro e fora das administrações municipais e que compromete a capacidade institucional e organizacional do setor público no gerenciamento estratégico da comunidade.

Elas perceberam que há uma certa relutância do setor público em adotar políticas com estratégias com perfil de desenvolvimento local pois estas não dão visibilidade à comunidade dos investimentos necessários e seus benefícios são sentidos apenas a médio e longo prazo ao contrário de tradicionais políticas de desenvolvimento como isenção fiscal e doação de terrenos.

Porém esta posição não reflete a visão de novos segmentos de negócios, mas sim daqueles setores econômicos e industriais mais tradicionais. Os novos empreendimentos sentem necessidade maior de apoio em planos de marketing e facilidades para expansão de mercado, e apoiam estratégias de risco para desenvolvimento de seus negócios. 
II. Desenvolvimento Econômico Local

\subsubsection{A Comunidade Empreendedora}

Sobre a questão do enfoque empresarial da comunidade no processo de desenvolvimento local, Kotler, Haider \& Rein acreditam ser fundamental que ele seja dinâmico e ativo. Eles indicam qualidades essenciais para se caracterizar uma localidade como empreendedora:

- Economia aberta e fluente, com poucos obstáculos para novos negócios;

- Estrutura social dinâmica, onde pessoas de fora são bem-vindas;

- Negócios competitivos, sem empregador predominante;

- Acesso a investimentos de risco, com bancos competitivos;

- Mão-de-obra especializada e profissional, contando com apoio para qualificação;

- Governo com apoio a pequenos e novos negócios;

- Inovação através de grande universidade e centro de pesquisa empresarial;

- Mídia com atenção para os empreendedores e para novos negócios;

- Empregos com base em estímulo a novos e pequenos negócios;

- Amenidades através de boa qualidade de vida com cultura e recreação.

Kotler, Haider \& Rein acreditam que a evolução das sociedades público-privadas na execução de projetos de interesse da coletividade, surgidas nas décadas de 1960 e 1970, veio influenciar a visão estratégica de governo, exigindo dos governantes locais uma performance empreendedora nas políticas de desenvolvimento econômico, incluindo as seguintes características:

- Finanças com impostos moderados; títulos públicos bem conduzidos;

- Dirigentes políticos pensadores; visionários; vendedores;

- Serviços de alta qualidade; inovadores; competitivos; 
II. Desenvolvimento Econômico Local

- Cultura de participação ampla dos cidadãos; aberta;

- Estilos profissionais; voltados para resultados;

- Burocracia com perfil empreendedor; novas maneiras de realizar;

- Gastos em investimentos; desempenho; resultados;

- Cidadãos vistos como consumidores e acionistas;

- Planejamento com previsão para vários anos; estratégico;

- Receptividade; bons ouvintes; negociadores; responsabilidades.

Antes que pelo governo, a transformação da localidade em um lugar atraente para negócios e estimulante para as atividades econômicas passa por uma ampla transformação da mentalidade dos agentes políticos e privados do desenvolvimento local. A comunidade empreendedora ao mesmo tempo que exige um novo modelo de administração mais ativo no campo econômico e um esforço de eficiência nas tarefas burocráticas coloca a comunidade empresarial em uma nova dimensão produtiva, onde a eficácia de sua operação no território está ligada a cooperação efetiva com os agentes locais de desenvolvimento.

\subsubsection{Parcerias Público-Privadas}

No processo de mudança da sociedade como um todo em direção a um "governo empreendedor", onde a prosperidade é atingida com crescimento e revitalização econômica do território, resultados de parcerias entre o setor público e privado e fundamentado no apoio da sociedade civil, acredita-se que deve prevalecer estratégias políticas para o desenvolvimento econômico local com a criação de ligações transparentes e eficientes entre as empresas e o governo.

Estrategicamente, o desenvolvimento econômico local é baseado na união de forças e recursos, públicos e privados, em novos arranjos e parcerias onde a sociedade busca com o setor privado estimular negócios em determinadas áreas, tendo-se como objetivo criar novos empregos e oportunidades econômicas.

Blakely sugere um real comprometimento entre os setores público e privado para que o processo de desenvolvimento local funcione, isto significa que ambos setores deverão ir muito além do simples relacionamento onde o setor público apenas oferece cooperação para que o setor privado atinja suas metas 
II. Desenvolvimento Econômico Local

através de infra-estrutura para facilitar sua atividades econômicas. Também não quer dizer que o setor público deva conduzir reuniões entre políticos e empresários para discutir questões setoriais. Ele afirma que embora estas funções das instituições públicas sejam importantes, e mesmo fundamentais para o bom relacionamento entre os dois setores, elas não devem ser consideradas de fato parcerias.

Analisando os casos bem-sucedidos das parcerias entre setores privados e públicos, pode-se dizer que "elas devem seguir as seguintes recomendações:

1. uma cultura cívica positiva que encoraje a participação do cidadão, que deve ser vista como um trabalho voluntário de longo prazo de interesse da comunidade. Os objetivos do desenvolvimento do projeto devem ser compartilhados pela comunidade. Instituições cívicas que ajudam a criar empregos e estimular a base econômica podem formar parcerias concretas, enquanto que instituições governamentais ou privadas setoriais, sem um claro papel no desenvolvimento local, não podem encontrar um campo comum onde possam formalizar uma parceria.

2. uma realística visão da comunidade, aceita por todos, baseada nas forças e fraquezas da área tanto quanto na concepção comum do potencial local. Esta é a mais importante para a formação de parcerias. Sem o comum entendimento do que a comunidade é e do que ela pode vir a ser é impossível construir uma melhor comunidade. Mais ainda, sem uma visão realística do potencial local, a comunidade jamais conseguirá atingir suas metas.

3. uma organização cívica efetiva que pode combinar o próprio interesse de seus membros com o interesse mais amplo da comunidade. Interesses próprios são sem dúvida o que incita a maioria das ações. Se os interesses das lideranças cívicas, individuais e coletivos, podem encaminhar através de alguma estrutura que possibilite a compreensão do que seja o interesse comum de toda a comunidade, então o processo de desenvolvimento pode ser beneficiado e funcionar melhor. 
II. Desenvolvimento Econômico Local

4. uma rede de grupos chaves e indivíduos que encoraje a comunicação entre as lideranças e facilite a mediação das diferenças existentes entre os diferentes interesses. Esta rede constrói respeito e confiança na comunidade. Ela permite tratar de negócios, trabalho e governo para extrair divergências tanto no setor privado quanto no setor público, dirigindo assim os focos da discussão para corrigir problemas de relacionamento entre os participantes do processo de desenvolvimento.

5. uma habilidade para conduzir empreitadas cívicas, que contemple o encorajamento de empreendedores sociais e o fortalecimento de seus ânimos. Nada é mais prejudicial para a noção de desenvolvimento econômico do que a comunidade não valorizar o trabalho voluntário de seus cidadãos. Um empreitada cívica, a qual pode demandar poucas, mas ativas e motivadas pessoas, em ações firmes para induzir uma área na criação de empregos e atividades econômicas, é uma tarefa de risco, que pode não dar certo. Se estas pessoas não são recompensadas e reconhecidas, o processo de desenvolvimento irá parar e a comunidade sofrerá uma perda difícil de ser recuperada.

6. continuidade política que deve ser capaz de se adaptar às circunstâncias em transformação, para que seja possível reduzir a incerteza para os negócios e para as pessoas que querem assumir riscos econômicos. Muito freqüentemente, o governo, na ausência de consistentes metas, persiste em políticas fragmentadas no processo de desenvolvimento. Há algumas maneiras de se evitar isto. Primeiro, a comunidade deveria trabalhar em um conjunto de políticas de desenvolvimento que funcionasse como uma estrutura para suas ações no campo do desenvolvimento. Por exemplo, a comunidade talvez pudesse adotar políticas que promovessem o desenvolvimento com a utilização de mão-de-obra intensiva. Mas, subseqüentemente, o efeito desta estratégia deveria ser avaliado dentro da estrutura proposta no conjunto de políticas de desenvolvimento. Segundo, governo local e empreendimento 
II. Desenvolvimento Econômico Local

privado, juntos com sindicatos e grupos comunitários, devem tentar determinar que tipo de comunidade eles realmente querem e construir infra-estruturas físicas e sociais de acordo com o tipo idealizado.

Estas seis recomendações formam a base para qualquer estrutura organizacional que a comunidade resolvesse adotar. Essencialmente, parcerias pública-privada são pontes de confiança baseadas em objetivos similares, porém plenos de diferenças nos papéis que cada um dos parceiros deve representar. Alcançar a cooperação entre os setores públicos e privados é o primeiro passo em direção a projetos concretos e os projetos que irão prosseguir facilmente se a estrutura estiver lá para facilitar os relacionamentos entre os parceiros"23.

Abordando a questão de parcerias público-privadas como um campo crescente das políticas de desenvolvimento econômico, Bennet \& Krebs destacam a importância de se estimular preferencialmente o desenvolvimento de "baixo para cima" nas iniciativas governamentais mais do que aquele implantado de "cima para baixo". Eles comentam a estratégia aplicada por vários programas do Comunidade Européia - CE - que buscam este enfoque através de parcerias locais como uma maneira de melhorar a eficácia das iniciativas desenvolvimentistas. Encorajar o potencial local tem sido uma maneira da CE agir para eliminar as disparidades regionais e facilitar os ajustes para implantar o Mercado Comum Europeu.

Eles analisaram a estrutura organizacional e parcerias na distribuição das tarefas para implantação dos programas propostos pela $\mathrm{CE}$ de acordo com o agente responsável pela atividade e com a economia regional. As cinco mais importantes atividades dos agentes de acordo com o tipo da área foram os seguintes:

\section{1. Áreas menos desenvolvidas}

a. Governo Central/Nacional

- Doações

- Empréstimos

- Garantias financeiras

- Apoio para cooperativas 
- Treinamento

b. Governo Local/Regional

- Provisão de áreas

- Promoção local

- Promoção internacional

- Workshops de treinamento

- Provisão de informações

c. Agências de Desenvolvimento

- Aconselhamento geral

- Orientação inicial

- Guia financeiro

- Promoção local

- Gerenciamento dos locais de trabalho

d. Câmara de Comércio

- Promoção internacional

- Promoção nacional

- Promoção local

- Workshops de treinamento

- Diretório de negócios

2. Áreas agro-industriais

a. Governo Central/Nacional

- Doações

- Empréstimos

- Aconselhamento geral

- Provisão de terras

- Isenção de impostos

b. Governo Local/Regional

- Provisão de áreas

- Provisão de informações 
- Orientação geral

- Workshops de treinamento

- Guia financeiro

c. Agências de Desenvolvimento

- Promoção nacional

- Promoção internacional

- Diretório de negócios

- Orientação geral

- Gerenciamento dos locais de trabalho

d. Câmara de Comércio

- Diretório de negócios

- Orientação geral

- Guia financeiro

- Registro de premissas

- Orientação inicial

3. Áreas em declínio industrial

a. Governo Central/Nacional

- Doações

- Empréstimos

- Orientação geral

- Promoção internacional

- Parque tecnológico

b. Governo Local/Regional

- Provisão de áreas

- Provisão de premissas

- Workshops de treinamento

- Aconselhamento geral

- Promoção nacional

c. Agências de Desenvolvimento 
- Aconselhamento geral

- Orientação inicial

- Guia financeiro

- Promoção local

- Workshops de treinamento

d. Câmara de Comércio

- Diretório de negócios

- Aconselhamento geral

- Promoção internacional

- Promoção local

- Orientação inicial

\section{4. Áreas desenvolvidas}

a. Governo Central/Nacional

- Doações

- Orientação geral

- Orientação inicial

- Promoção internacional

- Isenção de impostos

b. Governo Local/Regional

- Provisão de áreas

- Workshops de treinamento

- Orientação inicial

- Aconselhamento geral

- Promoção nacional

c. Agências de Desenvolvimento

- Orientação inicial

- Promoção internacional

- Promoção nacional

- Aconselhamento geral

- Provisão de premissas 
d. Câmara de Comércio

- Aconselhamento geral

- Orientação inicial

- Guia financeiro

- Promoção internacional

A atuação dos quatro agentes criou uma complexa inter-relação organizacional estruturada em múltiplas parcerias de acordo com a etapa do projeto em execução. E, apesar do entrelaçamento de papéis, o que dificultou a análise em uma dimensão simples e direta, Bennet \& Krebs puderam constatar:

1. nas áreas menos desenvolvidas o setor público tem o mais importante papel, com o setor privado se isolando e não participando integralmente dos projetos em parceria com o setor público;

2. nas áreas agro-industriais o setor público é tão importante agente quanto nas áreas menos desenvolvidas, mas nestas áreas são freqüentes as parcerias com o setor privado;

3. nas áreas em declínio industrial o setor público é o agente mais ativo, mas nestas áreas além das parcerias público-privadas são encontrados alguns projetos privados independentes;

4. nas áreas desenvolvidas os projetos denotam a predominância de iniciativas do setor público com uma pequena participação do setor privado de forma independente ou em parcerias, com exceção em projetos de financiamento onde predomina o setor privado, estimulado por taxas de juros.

Classificando as estratégias de desenvolvimento econômico local, Burnier aponta duas classes de políticas de desenvolvimento:

a. política de desenvolvimento incentivado - tradicional enfoque governamental de oferecimento de incentivos em formas de financiamentos e eliminação/redução de impostos para atração e locação de indústrias e estímulo a novos investimentos na região; 
II. Desenvolvimento Econômico Local

b. política de desenvolvimento estratégico - baseado em metodologia, aplicando conceitos empresariais clássicos como planejamento estratégico, posicionamento no mercado e busca de competitividade $^{24}$ regional, não apenas para atração e a locação das indústrias, como também para encorajar a capacidade empreendedora regional e estimular as atividades econômicas locais.

Burnier percebeu, ainda, a aplicação conjunta das duas políticas, embora sujeitas a restrições de fatores estruturais ${ }^{25}$ como: "ações estratégicas formatadas com parcerias público-privadas, como veículo preferencial visando aquisição de objetivos comuns de desenvolvimento, descentralização de responsabilidades, exclusão do planejamento econômico governamental, geração de empregos baseada em recursos de capital em vez de recursos humanos, e pragmatismo".

\subsection{Implantação do Programa de Desenvolvimento Local}

O processo de desenvolvimento local exige, para sua implementação, o estabelecimento de um conjunto de instrumentos baseados em alguns conceitos chaves que caracterizam as variáveis da localidade e determinam a direção da estratégia a ser seguida.

A combinação de características regionais e circunstanciais que afetam o local irá estabelecer um guia que fundamenta as tomadas de decisão que dirigem o plano de desenvolvimento específico da comunidade foco das ações do plano. Blakely aponta algumas delas:

- Zona de ação - estabelecimento da área geográfica foco do plano;

- Instituições - criação ou orientação de instituições e organizações públicas e privadas locais participantes do plano;

- Negócios Locais - caracterização de empresas e empreendimentos existentes na localidade objeto de estudo e ação do plano;

- Recursos Públicos - identificação de recursos financeiros financiadores da elaboração e implantação do plano; 
II. Desenvolvimento Econômico Local

- Base de Empregos - identificação dos recursos humanos locais para performance do plano.

Ele propõe uma divisão do planejamento e gerenciamento de desenvolvimento econômico local em fases e tarefas:

Fase I - Coleta e análise dos dados

- Determinação da base econômica

- Avaliação da estrutura atual de empregos

- Avaliação das necessidades de emprego

- Exame das oportunidades e restrições ao desenvolvimento econômico

- Exame da capacidade institucional

Fase II - Seleção da estratégia para o desenvolvimento local

- Estabelecimento de critérios e objetivos

- Determinação dos possíveis cursos de ação

- Desenvolvimento da estratégia escolhida

Fase III - Seleção dos projetos de desenvolvimento local

- Identificação dos projetos possíveis

- Avaliação da viabilidade do projeto

- Comunidade/Comercial/Locacional/Implementação

Fase IV - Elaboração dos planos de ação

- Pré-avaliação dos resultados do projeto

- Alimentação das entradas do projeto

- Estabelecimento das alternativas financeiras

- Identificação das estruturas do projeto

Fase V - Especificação dos detalhes do projeto

- Condução de estudos detalhados da praticabilidade

- Preparação do plano de trabalho

- Programa de desenvolvimento, monitoramento e avaliação 
II. Desenvolvimento Econômico Local

Fase VI - Preparação e implementação do plano global de desenvolvimento

- Preparação da agenda de implementação do plano de projeto

- Desenvolvimento de um programa global de desenvolvimento

- Determinação e marketing dos recursos da comunidade

- Negociação das necessidades financeiras

\subsubsection{Planejamento Estratégico}

A inserção das parcerias com o setor privado no desenvolvimento local reforçou o peso da visão empresarial nas iniciativas locais e trouxe conceitos da teoria do planejamento estratégico para implantação de programas de desenvolvimento econômico local, com muitas comunidades em todo o mundo adotando esta metodologia para desenvolvimento de suas economias locais.

Blakely vê de forma positiva a introdução desta metodologia pelo seu enfoque baseado em previsões do futuro da comunidade em um ambiente econômico onde se inserem as necessidades locais. Ele minimiza a origem militar do termo estratégico dizendo que este tipo de planejamento contém as exigências suficientes para sua aplicação em desenvolvimento econômico local por contar com "a utilização de todas as forças de uma localidade, as quais são inseridas em uma abrangente meta de longo prazo, para assegurar sua implantação".

Portanto, pode-se considerar como positiva a adaptação às nuanças das comunidades interessadas no desenvolvimento econômico local do que era uma prática comum nas corporações empresariais. Assim, muitas comunidades vêm usando planejamento estratégico há alguns anos, reconhecendo as agências governamentais ${ }^{26}$ e não-governamentais em todo o mundo este processo como uma eficiente maneira de avaliar custo e benefícios no ambiente econômico, além de construir um instrumento para monitoramento de projetos, facilitando o sucesso dos empreendimentos.

Seu mérito vem do fato que identifica de forma sistemática as vantagens e desvantagens de uma área, determina oportunidades para seu crescimento, fornece um senso de direção para programas locais de forma que o crescimento possa ser alcançado e provê um cenário para a avaliação e 
II. Desenvolvimento Econômico Local

modificação do programa de desenvolvimento econômico, a partir de uma análise de estratégias locais viáveis para a promoção de desenvolvimento econômico ${ }^{27}$.

$\mathrm{Na}$ aplicação desta metodologia, há necessidade de acompanhar a permanente evolução mundializada das atividades econômicas que causa mudanças nas economias locais, provocando o surgimento de novas visões para o gerenciamento dos valores da comunidade ${ }^{28}$, ligados ao modo de produção industrial.

Com este objetivo, Doeringer \& Terkla (1990) mostram uma classificação de empresas através da determinação da estratégia na performance de produção:

1. inovação;

2. produção em massa;

3. produção customizada (personalizada);

4. produção híbrida.

As empresas com características de inovação e produção em massa seguem o tradicional modelo de ciclo-de-produto. O sucesso ou fracasso de empresas inovadoras dependem da expansão do mercado para o produto e é relativamente insensível à competição de custos, dizem Doeringer \& Terkla. Como estas empresas de ciclo-de-produto evoluem do início da inovação para a maturação como produtores em massa, elas se tornam crescentemente vulneráveis à competição de custos e suas estratégias locacionais se tornam sensíveis a estruturas de custos locais.

Em oposição, produtores de produtos personalizados e empresas híbridas que combinam personalização com produção em massa acreditam em estratégias de especialização dos produtos. Eles tendem a operar em nichos de produto onde a competição é mais sensível à qualidade e velocidade de entrega do que a preço. Estes produtores especializados são altamente dependentes de fatores econômicos invisíveis viáveis para eles na região - qualidade da força de trabalho, ambiente empresarial-trabalhista, e relações de cooperação com empresas locais, perceberam Doeringer \& Terkla. 
II. Desenvolvimento Econômico Local

Neste contexto, dizem os pesquisadores, a performance da economia local depende do mix das estratégias das diferentes empresas presentes na comunidade, mais do que um mix de velhas e novas empresas, na verdade este desempenho depende mais ainda das relações destas estratégias de produção com os fatores invisíveis da comunidade. Viram eles, então, a importância de centrar os esforços de desenvolvimento em empresas, não em indústrias, usando os incentivos de fatores invisíveis locais como base para construir a economia local. Desta forma, releva-se a vocação das pequenas e médias localidades para o desenvolvimento local que vem da capacidade endógena de absorver companhias de alta tecnologia que não precisam estar locadas próximas aos mercados, como as de baixa tecnologia ${ }^{29}$.

Ottansmeyer, Humphey \& Erikson (1987) não acreditam que seja possível o desenvolvimento econômico local sem que haja uma confluência de estratégias entre o setor público e o setor privado.

De um lado, dizem eles, empresas encaram continuamente ações estratégicas referentes a decisões de investimentos e de produção. Tais decisões, freqüentemente são baseadas em novas tecnologias de processo e produto, devendo envolver o início de um novo empreendimento, a expansão ou redução de uma planta, a abertura de uma filial, a relocação de uma estrutura produtiva em outro local ou o fechamento de uma unidade. As empresas envolvem neste tipo de decisão costumeiramente consultores, agências governamentais e instituições de apoio setorial. Um conjunto de informações como oferta de mão-de-obra, perfil dos trabalhadores, salários, infra-estrutura, taxação de impostos, e outros dados pertinentes às decisões são levantados diretamente com representantes das áreas selecionadas.

Por outro lado, continuam eles, comunidades locais estão engajadas em um sistemático esforço para melhorar seus ambientes econômicos. Vários incentivos econômicos são freqüentemente usados para ajudar os negócios a se expandirem ou manterem suas atividades na região. Aquisições de terrenos, descontos em impostos e taxas ou subsídios são ações implementadas em todos os níveis governamentais. Fornecimento de infra-estrutura, emissões de concessão e intervenções políticas podem afetar as decisões de investimentos das empresas e 
II. Desenvolvimento Econômico Local

são estratégias usualmente utilizadas pelos estrategistas do setor público para influenciar as escolhas estratégicas do setor privado.

Este variado conjunto de condições, incentivos e ofertas de serviços, segundo Ottansmeyer, Humphey \& Erikson, deve constituir-se na estratégia de desenvolvimento de uma área. Ela pode estar formalmente disposta em um plano, onde as fraquezas e forças regionais formam o "produto" a ser oferecido e o "mercado" a ser conquistado. Quando isto acontece, uma conexão entre as expectativas empresariais e comunitárias, obtém-se uma estratégia concreta, que deve ser conduzida através de um processo de planejamento no qual a comunidade deve ter o principal papel.

Kotler, Haider \& Rein (1995) abordam a questão da evolução histórica do planejamento estratégico de marketing aplicado no contexto das comunidades americanas, dividindo em três gerações de desenvolvimento econômico:

A primeira fase foi aquela em que a estratégia era correr atrás de fábricas. Sua origem é a década de 30, quando os estados do sul dos EUA, através de esforços agressivos, buscaram atrair as fábricas e investimentos oriundos do norte dos EUA oferecendo "ambientes comerciais melhores" com vantagens de um custo de produção menor, através de mão-de-obra e terras baratas, impostos baixos e financiamento público.

A segunda etapa, nas décadas de 80 e 90, mostra as localidades aplicando estratégias baseadas no conceito de marketing-alvo. Neste caso, em vez de tentar atingir uma única meta, a de atrair indústrias, os esforços se dirigiam para múltiplos objetivos. A preocupação não seria apenas atrair empresas, mas também reter e estimular as que já estavam locadas na região. $\mathrm{O}$ turismo seria visto como uma atividade econômica de alto valor multiplicador. Os negócios com o exterior, facilitados com a globalização, deveriam ser encarados mais como oportunidades para a expansão do mercado para os produtos locais do que ameaça a economia regional. Os investimentos estrangeiros tornavam concretas as possibilidades de parcerias internacionais para estimular as atividades econômicas locais. 
II. Desenvolvimento Econômico Local

Kotler, Haider \& Rein perceberam que "à medida que a economia americana foi mudando e a concorrência aumentando, as localidades deixaram para trás aquela abordagem descuidada e arriscada do tudo-ou-nada e partiram para estratégias mais refinadas, baseadas no estudo da concorrência e do posicionamento do mercado".

$\mathrm{Na}$ terceira etapa de planejamento estratégico, desta vez baseado na criação de produto e conceito de nicho, iniciada durante a década de 90, os locais procuram se definir como lugares especiais que oferecem vantagens competitivas específicas para atender determinadas indústrias-alvo.

Estas etapas, embora independentes, não são necessariamente excludentes, refletem, apenas, as mudanças na economia global, onde se inserem o crescimento, o desenvolvimento e sofisticação da competição entre as localidades em busca da garantia de sua própria sobrevivência.

Constatando a função instrumental do planejamento estratégico, Kotler, Haider \& Rein afirmam que "nesse processo dinâmico, o marketing de localidades surgiu como um processo de integração promissor que ligava as vantagens competitivas de um local aos objetivos gerais do desenvolvimento econômico".

\subsubsection{Missão}

A implementação do planejamento estratégico local de desenvolvimento é um processo de interação entre o conjunto de metas e as ações engendradas para atingi-las e é em essência gerenciamento, onde a atuação requerida é bem mais complexa do que uma simples execução de instruções administrativas empresariais. Assim, o planejamento irá trabalhar com um plano de ações, baseado em metas e recursos disponíveis, havendo necessidade de determinar a missão do planejamento que deve estabelecer a racionalidade para o conjunto de ações a serem adotadas.

"Missão é o que caracteriza, identifica e justifica a existência de uma instituição. Ela pode ser dividida em quatro partes interrelacionadas: finalidade, estratégia, comportamento e valores. Finalidade explica porque uma organização existe: para quais benefícios todos os esforços estão sendo realizados. Estratégia considera a natureza do objeto da organização, o posicionamento desejado frente a 
II. Desenvolvimento Econômico Local

outras instituições e a fonte da vantagem competitiva. Padrões de comportamento, normas e regras para atuação da organização. Valores são as crenças e princípios morais que estão por trás dos padrões de comportamento, sendo as crenças normalmente formuladas no seio da organização pela tradição administrativa, pelos fundadores ou pela equipe administrativa" ${ }^{\prime 3}$.

O elemento estratégia da missão indica o que é importante para o futuro da instituição, enquanto os valores indicam o que é importante na cultura da organização. A missão fica bem definida quando há uma perfeita sintonia entre os dois elementos, e amalgamada pelo propósito comum entre estratégia e valores fornece à organização segurança para atingir suas metas.

É a missão uma proposta de encaminhamento das ações pelas quais uma instituição deve se responsabilizar, sendo uma agência de desenvolvimento local a organização que pode gerenciar este processo, responsabilizando- se pelas ações no contexto territorial de sua atuação, como estará exposto mais adiante nesta tese, no próximo capítulo.

\subsubsection{Ações Estratégicas}

O grupo de trabalho de planejamento estratégico do seminário Metropolis'93 Montreal $^{31}$ apresentou algumas recomendações para aplicação deste tipo de planejamento nas ações do setor público, concluindo que a aplicação do planejamento estratégico em cidades e regiões envolve um conjunto de orientações e instrumentos de implementação mais complexo do que o tradicional planejamento usando a ferramenta de controle do uso do solo, e que, por isso, os técnicos envolvidos devem estar familiarizados com custos e benefícios dos projetos e participar ativamente não apenas da formulação como também da implementação das ações que eles requerem.

O grupo recomendou que o processo obedecesse às seguinte etapas:

1. Reconhecimento preliminar e definição das tarefas de acordo com a orientação geral onde a atividade de planejamento se insere;

2. Coleta de dados, análise, pesquisa e diagnóstico;

3. Formulação de metas e objetivos, e seleção das variáveis essenciais; 
II. Desenvolvimento Econômico Local

4. Desenho dos cursos de ação e alternativas;

5. Avaliação e seleção da estratégia preferida;

6. Desenho da estratégia preferida, propósitos principais e programa de trabalho;

7. Implementação e estrutura de funcionamento;

8. Monitoramento e revisão.

Estas tarefas fazem parte de um processo cíclico e, assim, o trabalho em cada estágio irá fundamentar o próximo, sucessivamente até a implementação. A simplificação do processo é necessária para iniciar os trabalhos, talvez, com o processo em andamento, um determinado estágio possa necessitar de uma maior complexidade, abrindo esta etapa para outras tarefas.

Há, em planejamento estratégico, algumas ferramentas básicas como a matriz SWOT (Strengths, Weakness, Opportunities e Threats) criada com o propósito principal de ajudar uma organização a encontrar o melhor ajuste entre seu perfil operacional e o meio em que atua, ou seja, formular a estratégia mais adequada para o desempenho empresarial. Ela pode ser aplicada para o planejamento de localidades, observando-se algumas adaptações em seus conceitos.

A matriz SWOT no contexto urbano envolve:

- análise externa, na qual pontos-chave de ameaças e oportunidades são destacados do meio externo; e

- análise interna, a qual identifica as fraquezas e forças relativas a cada tema estratégico.

Estas perspectivas são importantes porque ambos fatores, externos e internos, irão afetar a capacidade de uma localidade atingir as metas propostas no plano, e devem ser cuidadosamente elaboradas para determinar as ações estratégicas e garantir o sucesso do objetivo de planejamento.

Quanto às ações, Reese (1993) constatou a diversidade nas adotadas em cidades americanas para implantar programas de desenvolvimento econômico 
II. Desenvolvimento Econômico Local

local. Ela as dividiu em categorias, classificando os instrumentos e atividades. São elas:

\section{Atividades de Marketing}

- Inventário de terrenos viáveis

- Brochuras

- Vídeos

- Prospectos para visitantes

- Atração de novas empresas

- Exposições

- Desenvolvimento de mercado para exportação

- Promoção de áreas

- Planejamento de eventos

- Planejamento e implantação de plano de marketing

\section{Instrumentos Financeiros}

- Descontos em impostos e taxas

- Pagamentos facilitados de impostos e taxas

- Garantias de empréstimos

- Empréstimos subsidiados

- Empréstimos diretos aos negócios privados

- Parceria em projetos

- Comodatos com opção de venda de áreas

- Contribuição financeira em projetos

- Doação de terrenos

- Emissão de ações

- Treinamento e retreinamento de mão-de-obra

- Serviços de gerenciamento de empreendimento

3. Atividades de gerenciamento urbano

- Melhoria da coleta e tratamento de esgoto

- Melhoria do sistema de tratamento de água

- Facilidades para loteamentos de grandes áreas

- Desapropriação de áreas 
- Aquisição de áreas

- Relocação de empresas

- Reativação de áreas urbanizadas e sem uso

- Venda de áreas para empreendedores imobiliários

- Leasing de áreas para empreendedores imobiliários

- Doação de áreas para empreendedores imobiliários

- Transferências de direitos de desenvolvimento

- Gerenciamento de propriedades

- Gerenciamento de propriedades industriais

- Reabilitação de construções desativadas

- Assistência técnica para gerenciamento imobiliário

\section{Instrumentos governamentais}

- Desburocratização para emissão de licenças para projetos

- Melhoria do sistema de inspeção e aprovação de edificações

- Ombudsman para resolução de problemas

- Modificação de zoneamento

- Relaxamento de regulações ambientais

- Melhoria e expansão de estacionamento

- Melhoria das vias de circulação de veículos e do trânsito

- Melhoria da segurança pública

- Melhoria da coleta e tratamento do lixo

- Melhoria de facilidades para o tráfego de pedestres

- Melhoria e expansão das áreas de lazer

- Melhoria do visual da cidade

- Incentivos à preservação da história local

- Adoção de regulação aos lugares históricos

- Adoção de regulação para sinalização visual

- Adoção de regulação para fachadas

- Adoção de programas e regulação anti-lixo

Reese considera que as categorias que englobam atividades voltadas para marketing, incentivos financeiros e disponibilização de áreas, deveriam adotar técnicas diferenciadas para objetivos específicos de demanda e oferta 
II. Desenvolvimento Econômico Local

urbana. Os incentivos pelo lado da oferta urbana seriam direcionados a reduzir os custos para as atividades empresariais em uma localização específica e assim atrair mais investimentos. Os incentivos pelo lado da demanda urbana seriam direcionados para encorajar e estimular novos empreendimentos e desta forma tenderiam a ser mais de natureza empresarial. Estas atividades deveriam ser diretamente voltadas para estimular a demanda para produtos da região e promover a participação de empreendedores locais. As lideranças da comunidade precisam ter certeza de qual tipo de desenvolvimento a localidade tem em mente quando iniciam seus trabalhos para não dispersarem esforços nas atividades que não irão atender as expectativas da população.

Azevedo (1995) identificou três ações-chave em um conjunto de diversificadas estratégias de políticas locais para criação de um ambiente favorável a melhoria da eficácia das empresas:

1. iniciativas voltadas à criação e à expansão de empresas - as vantagens decorrentes da proximidade geográfica atraem novas empresas e contribuem para o desenvolvimento daquelas já existentes; essas vantagens entretanto não levam somente a uma redução dos custos de produção, mas a inovações nas áreas da produção e de mercado. No âmbito do aparelho produtivo, a reestruturação dos sistemas produtivos locais e regionais está se realizando não só através de mudanças nos processos produtivos (mudanças na organização das empresas em função da introdução de novas tecnologias) como também mediante a fabricação de novos bens e/ou diferenciação da produção, o que significa, em termos de comercialização, a possibilidade de ocupação de novos mercados;

2. fomento da mudança tecnológica - trata-se de organizar territorialmente as mudanças tecnológicas, de tal modo que as empresas possam introduzir, de forma eficaz e rápida, novas tecnologias, ajustando-se às condições do sistema produtivo e as empresas locais; em alguns casos é possível aproveitar o potencial tecnológico existente na região, porém o mais freqüente é a importação de know-how empresarial proveniente de outras áreas, 
II. Desenvolvimento Econômico Local

o que supõe a introdução de inovações tecnológicas pela imitação ou adaptação de tecnologias externas;

3. formação técnica e qualificação do trabalhador - realização de programas de requalificação de mão-de-obra, o que pode implicar reordenação de escolas ou mesmo criação de escolas técnicas adaptadas às exigências dos novos processos de produção.

Para idealizar ações estratégicas para o desenvolvimento local, indagaram-se Kotler, Haider \& Rein como as localidades deveriam reagir aos desafios-chave que estão enfrentando, provocados pelo impacto que a grande transformação da economia mundial está causando ao mundo, como:

1. Aceleração do ritmo de mudanças no ambiente da economia, da política e da tecnologia;

2. Processos normais de evolução e decadência urbana;

3. Crescimento do número de concorrentes na disputa dos recursos externos;

4. Dependência crescente de recursos próprios para atração de investimentos.

Kotler, Haider \& Rein apontam ações básicas para o desenvolvimento de um local, o qual pode ser considerado como um modelo para conduzir o desenvolvimento de localidades no século XXI. Segundo eles, as respostas aos desafios-chave da internacionalização da economia seriam:

1. As localidades precisam definir uma visão estratégica para enfrentar estes desafios;

2. As localidades precisam definir um processo de planejamento de marketing para enfrentar estes desafios;

3. As localidades têm de adotar uma perspectiva de mercado legítima em relação aos seus produtos e clientes;

4. As localidades precisam estabelecer qualidade em seus programas e serviços para competir com outras; 
II. Desenvolvimento Econômico Local

5. As localidades precisam de habilidade para transmitir e divulgar eficientemente suas vantagens competitivas;

6. As localidades precisam diversificar sua base econômica e criar mecanismos para se adaptar flexivelmente às novas condições;

7. As localidades precisam desenvolver e alimentar características empreendedoras;

8. As localidades precisam contar mais com o setor privado para executar sua tarefas;

9. Cada local precisa elaborar o seu próprio processo de mudança, como resultado das diferenças culturais, políticas e processos de lideranças;

10. As localidades precisam criar alguns mecanismos organizacionais e de procedimento que sustentem o seu desenvolvimento e mantenha, uma vez iniciada, a força adquirida.

A implantação deste conjunto de ações prescinde de uma colaboração mútua para empresas e governo trabalharem juntas e que irá se traduzir em benefícios moldados por culturas, tradições e instituições que estão obrigando lideranças empresariais e políticas a repensarem seus projetos e propostas.

E, segundo Kotler, Haider \& Rein, "se a tendência no sentido de acabar com as fronteiras entre os países acelerar-se, como achamos que vai ocorrer, as regiões e localidades econômicas transcenderão as fronteiras políticas. Numa economia sem fronteiras, elas surgirão como os novos atores no palco mundial".

A capacitação dos recursos coletivos e individuais da comunidade, apontam os pesquisadores, irá viabilizar a criação de instrumentos e oportunidade para enfrentar as forças poderosas, externas e internas, que agem nas localidades. Pensam eles que as reações à nova ordem econômica devem surgir de baixo para cima, elevando a importância das regiões ao mesmo nível que das nações no desafio competitivo global .

\subsection{Atores do Desenvolvimento Local}


II. Desenvolvimento Econômico Local

A materialização das políticas e estratégias da comunidade têm sido realizada por grupos de lideranças comunitárias que vêm atuando através de comissões, conselhos, autarquias municipais e, mais recentemente, agências de desenvolvimento local que coordenam os papéis e as atividades das lideranças locais no processo de desenvolvimento da localidade.

É fundamental que os atores locais de desenvolvimento da comunidade estejam participando não apenas das atividades do formato de planejamento, mas também, com o mesmo empenho, da consecução dos objetivos do plano, sendo essencial para "a definição e aplicação dessas políticas e estratégias:

Primeiro, os empresários que desempenham o papel de animadores ou de mediadores do ajuste produtivo. Reunidos em associações locais, eles definem e se responsabilizam pela gestão dos recursos do ambiente que são considerados úteis às empresas. Essas associações buscam, em última análise, promover a colaboração entre empresas, de modo a modernizá-las e a melhorar sua competitividade;

Segundo, os administradores públicos locais, aos quais cabe identificar demandas das empresas, assim como incentivar a mobilização de recursos científicos e tecnológicos locais;

Terceiro, as instituições locais (universidades e institutos de pesquisa), que por sua vez, através de iniciativas de mudanças tecnológicas e de formação de mão-de-obra, reforçam e complementam os ajustes produtivos das forças de mercado. Neste aspecto, elas são responsáveis pelo treinamento da mão-de-obra (condição indispensável para que se eleve a produtividade do sistema), cuja qualificação deve adaptar-se às novas condições de produção",32.

Extraindo-os da experiência espanhola que desde 1986, através do Instituto Nacional de Empleo com a colaboração de administrações municipais, vem promovendo a criação de agências de desenvolvimento local, Martin (1996) aponta os atores para a criação de um plano de desenvolvimento local. São eles:

a. atores ligados à tomada de decisão (políticas e institucionais);

b. atores ligados às técnicas (profissionais e especialistas); 
II. Desenvolvimento Econômico Local

c. atores ligados a ações sobre o espaço local (a população e todos os demais agentes locais do desenvolvimento).

Destaca ainda o pesquisador espanhol que o êxito das iniciativas planejadas para o desenvolvimento local depende da participação efetiva dos atores que devem protagonizar seus papéis.

As funções ideais dos agentes seriam:

a. função de integração (buscar a lógica do território, suas necessidades e potencialidades; apoiar as articulações entre o setorial e o global, entre o econômico, o social e o cultural);

b. função de mediação (ponto de apoio para os diversos atores para a concepção e realização de um projeto; favorecer as condições para a tomada de decisão; garantir o fluxo permanente de informação e a conexão entre os atores; capacidade de negociação; desenvolver atitudes de negociação);

c. função de inovação e mobilização (escutar e descobrir as necessidades profundas da população e traduzi-las em um projeto de desenvolvimento viável e aceitável por todos; mobilização dos recursos locais e humanos, promover as iniciativas da comunidade; garantir a participação nos projetos).

A eficácia do planejamento, complementa Martin, será obtida com a complementaridade e interdependência destas três funções, que deverá materializar-se em:

a. análises territoriais que expressem a problemática global das zonas produtivas;

b. projetos de desenvolvimento elaborados com base em uma realidade e não em cenários genéricos;

c. animação social que conduza à participação;

d. comunicação que promova projetos de desenvolvimento e, por último; 
II. Desenvolvimento Econômico Local

e. gestão dos planos de desenvolvimento com capacidade de análise, acompanhamento e controle dos resultados.

\subsubsection{O Empreendedor Cívico}

Henton, Melville \& Walesh (1997), inspirando-se nas observações de Peter Drucker ${ }^{33}$ sobre a emergência do terceiro setor na sociedade do conhecimento com atividades específicas, além das do setor público e do setor privado, identificam o surgimento de um ator fundamental nas comunidades que aderem à "Nova Economia": o empreendedor cívico.

Os pesquisadores vêem nas localidades empreendedoras, onde se estabelecem forte ligações entre a comunidade e a economia, três características básicas:

1. "Clusters" especializados engajados - concentração de empresas que criam prosperidade em regiões através de exportação e estão engajadas em suas comunidades para atender mútuas necessidades;

2. Competências comunitárias conectadas - os bens e processos que criam as fundações para "clusters" competitivos e sustentam a alta qualidade de vida;

3. Empreendedores cívicos que ligam economia e comunidade lideranças que conectam "clusters" econômicos e competências da comunidade para promover vitalidade econômica e a qualidade de vida da comunidade.

Os atributos essenciais do empreendedor cívico, segundo Henton, Melville \& Walesh, são:

1. Visão de oportunidades na "Nova Economia";

2. Personalidade empreendedora;

3. Liderança cooperativa para conectar a economia à comunidade;

4. Motivação para demorados e incertos retornos de longo prazo;

5. Disposição para trabalho em equipe e para complementar papéis. 
II. Desenvolvimento Econômico Local

"Embora os empreendedores cívicos possam vir de qualquer área ou setor, nós observamos que toda equipe de empreendedores cívicos inclui em seu núcleo lideranças que vieram do setor privado. Esses líderes vêem seus futuros empresariais conectados às suas comunidades" afirmam Henton, Melville \& Walesh.

Os pesquisadores caracterizam, ainda, os papéis a serem desempenhados pelo empreendedor cívico na construção de uma nova economia na comunidade:

1. Motivador - no início, o primeiro papel do empreendedor cívico é criar um senso de urgência para mudanças na comunidade para enfrentar o desafio da globalização de maneira que os participantes compartilhem uma missão;

2. Conectador - ainda na iniciação, o segundo papel do empreendedor cívico é estabelecer a conexão eficiente os participantes de forma a oferecer credibilidade à rede de trabalho, tornando-a viável;

3. Professor - iniciado o trabalho, com o comprometimento e conexão da comunidade, o papel seguinte do empreendedor cívico é criar nos participantes um entendimento comum das questões estratégicas, ajudando a construir um fórum permanente de discussões sobre o futuro da comunidade;

4. Condutor - ainda na incubação, proteger e enriquecer o processo é papel do empreendedor cívico, mantendo as regras e disciplina para condução das iniciativas, e ajudando a encontrar as pessoas certas para as funções exigidas no trabalho em equipe;

5. Integrador - quando, na implantação do projeto, o empreendedor cívico deve atuar como um investidor de capital de risco, mas com a cabeça de cidadão, monitorando as alterações de comportamento dos dirigentes e forjando compromissos sérios destes com as mudanças, contando para isto com um time de primeira classe para apoio de sua atuação; 
II. Desenvolvimento Econômico Local

6. Maestro - também na implementação, o papel de maestro assegura ao empreendedor cívico a direção no caminho estipulado e que a meta será atingida, evitando a fragmentação, duplicação ou rigidez no enfoque dos trabalhos, garantindo o foco inicial e os objetivos propostos;

7. Mentor - no aperfeiçoamento e renovação, o empreendedor cívico tem o papel de mentor para estimular o surgimento de futuros empreendedores cívicos que irão se responsabilizar pela permanência do processo na comunidade, garantindo $o$ funcionamento futuro das estruturas e plataformas organizacionais criadas para iniciar, incubar e implementar o projeto;

8. Agitador - ainda contribuindo para o aperfeiçoamento e renovação do processo, o empreendedor cívico atua assumindo o papel de empurrar a comunidade na direção escolhida, ele é um incansável batalhador, acreditando sempre que há um caminho para superar as dificuldades e levar a comunidade a um futuro melhor.

Henton, Melville \& Walesh vêem o papel do empreendedor cívico como vital para ligar a economia da comunidade na nova rede de trabalho global. Dirigentes e executivos empresariais, funcionários públicos, consultores em desenvolvimento público ou privado, dirigentes e executivos de organizações governamentais, cidadãos comuns, profissionais da mídia, todos podem desempenhar este papel.

A exigência básica para isto é o desejo de construir uma conexão e uma integração eficazes entre a região e a economia global, moldando a localidade para um relacionamento internacionalizado onde uma cultura de compartilhamento de visão, trabalho, decisões e ações seja a força motriz do desenvolvimento econômico da comunidade. 
II. Desenvolvimento Econômico Local

\section{Agências de Desenvolvimento Econômico Local}

A materialização das políticas e estratégias idealizadas pelos atores do processo de desenvolvimento econômico da comunidade tem sido realizada através de comissões, conselhos, autarquias municipais e, mais recentemente, por meio de agências de desenvolvimento local que para eles servem como espaço de reflexão, coordenação e ações no processo de desenvolvimento da localidade.

O surgimento das agências de desenvolvimento local é conseqüência de alterações no "tradicional padrão centralizado de formular e operar políticas públicas - marcado pela verticalidade na relação Estado-Sociedade, pela generalidade espacial e segmentação setorial - dando lugar a um padrão descentralizado, caracterizado pela horizontalidade dessa relação, pela interação dos agentes/atores sociais envolvidos e pela seletividade espacial, integração e territorialidade das políticas públicas" ${ }^{\text {. }}$.

Em uma agência de desenvolvimento local a perspectiva de condução de um processo de desenvolvimento regional sob o amparo de um planejamento apoiado pela lógica de uma coordenação externa central cede lugar a um plano de gestão das iniciativas locais.

Esta gestão voltada para a consecução de projetos é, neste tipo de agência, fundamentada sob a visão territorial onde novos conceitos, como o de desenvolvimento endógeno, norteiam a difusão do crescimento econômico e a geração de empregos a partir do gerenciamento dos potenciais intrínsecos regionais estabelecidos em projetos estratégicos.

Segundo Macedo (1998), “apesar da variedade de suas atividades, de seus âmbitos de atuação e de suas formas institucionais, as AD's são, em geral, organismos que vêm sendo criados sob o amparo do Setor Público (União, Estados ou Municípios) para a promoção do desenvolvimento de uma zona territorial determinada (estado, região ou localidade), embora não sejam necessariamente de propriedade exclusivamente estatal. Situam-se, em geral, no meso plano entre o público e o privado (nível público, mas não estatal) e são criadas de maneira concertada entre os agentes sociais envolvidos e, mesmo quando exclusivamente estatais, possuem elevada autonomia de ação. Quase sempre na perspectiva de um regionalismo aberto, as AD's atuam fortemente no 
II. Desenvolvimento Econômico Local

âmbito da integração interna e externa da região onde concretiza suas atividades, via definição de estratégias de desenvolvimento endógeno e de acesso a mercados e de atração de capitais extra-regionais".

Criticando a ineficácia da administração pública para gerenciar as políticas de desenvolvimento econômico e observando que "os recursos gerenciais e interpretativos mais adequados se encontram no setor privado, porém as empresas dispõe de uma cobertura territorial limitada, pouco tempo e poucos recursos para compreender e enfrentar questões de responsabilidade social", Bennet (1993) acredita ser útil o modelo de agências de desenvolvimento não apenas por representar uma forma de apoio eficaz, mas também por permitir incorporar características essenciais do mundo de negócios.

\subsection{Tipos de Agência de Desenvolvimento Local}

Blakely aponta a influência das circunstâncias locais na estrutura institucional viável para gerenciar o desenvolvimento econômico local e destaca duas características fundamentais que a organização responsável pela gestão do processo deve ter:

1. Autoridade - o poder legitimado pela confiança nela depositada pelo governo local, comunidade, sindicatos, empresas e outras instituições e grupos;

2. Recursos - humanos, financeiros e técnicos, aceso a informação e outros recursos necessários para desenvolver projetos e programas.

Segundo ele, podem existir três tipos de organização de desenvolvimento local:

O primeiro e mais tradicionalmente adotado é a agência ligada diretamente a administração municipal. Ela funciona geralmente em lugares onde o governo assume o papel principal de agente de desenvolvimento, sendo mais comum em cidades de porte maior. Nas cidades menores a dificuldade existe por exigir um formato de uma secretaria ou departamento municipal o que implica em altos custos para contratar uma equipe relativamente grande, formada por técnicos e executivos, além de diretores e funcionários burocráticos. O funcionamento 
II. Desenvolvimento Econômico Local

deste tipo de agência carrega uma grande quantidade de burocracia, o que afasta empresários acostumados ao dinamismo de tomadas de decisões ágeis, o que não é possível na agência estatal.

O segundo é um modelo baseado em uma agência privada independente. O papel coordenador geralmente fica com a associação comercial local e cuida de projetos setoriais específicos de interesse da comunidade empresarial da região, como, por exemplo, turismo e comércio. Algumas localidades menores adotam esta estrutura para iniciativas de desenvolvimento local por agregarem com mais facilidades os empresários aos projetos de interesse coletivo. Há uma restrição à participação do setor público porque os investimentos estão normalmente ligados a riscos financeiros que os recursos públicos não podem correr. Desta forma, a participação do governo local fica restrita a cessão de terrenos e concessão de incentivos fiscais aos projetos deste tipo de agência privada.

O terceiro funciona como uma agência de desenvolvimento econômico local e congrega os interesses gerais de todos os segmentos da comunidade. A participação tanto do setor público quanto do privado, apesar de haver instâncias onde um ou outro fique ou prejudicado ou beneficiado, possibilita que se reunam todos os recursos potenciais da comunidade para o crescimento das atividades econômicas na região. Se o setor público e o privado tiverem partes iguais na corporação com uma divisão de deveres e obrigações esta abordagem institucional pode ser um excelente veículo e deveria gozar de forte apoio das organizações público e privadas voltadas para o desenvolvimento econômico.

\subsection{Estrutura da Agência de Desenvolvimento Local}

Blakely diz que a estrutura de uma agência de desenvolvimento local pode ser muito sofisticada ou relativamente simples. Ele indica para estas agências de desenvolvimento econômico estruturas moderadamente complexas, desde que a característica mais importante desta forma institucional possa desempenhar todas as tarefas que o governo local lhe delega enquanto age como organismo privado. Entre as atividades essenciais, o pesquisador dá como exemplo: 
II. Desenvolvimento Econômico Local

- administrar fundos de desenvolvimento contando tanto como recursos de fontes públicas quanto privadas;

- gerenciar propriedades públicas industriais ou comerciais para o governo;

- operar serviços em ação conjunta pública-privada;

- entrar em contato e conseguir empréstimos para vários projetos de desenvolvimento da comunidade;

- empreender atividades de marketing e promoção da localidade;

- fornecer serviços voltados aos empresários;

- funcionar como centro de assistência a pequenos negócios;

- fornecer assistência técnica e de marketing para firmas locais;

- dar apoio a esforços do governo para atrair indústria e comércio.

Acredita Blakely que a agência de desenvolvimento local, constituída com a participação do setor público em parceria com o setor privado, é a estrutura mais flexível que uma comunidade pode contar para adquirir competitividade regional, desde que aja um comprometimento concreto dos atores locais no processo de desenvolvimento da localidade. 


\section{Experiências de Agências de Desenvolvimento}

Vê-se, então, que projetos de desenvolvimento econômico local relevantes, como exposto até aqui neste estudo, podem ser implementados pela inovadora ferramenta de planejamento e gerenciamento conceituada como agência de desenvolvimento.

A seguir estão colocadas algumas das muitas experiências aplicadas já há algum tempo em países que podem ser considerados como pioneiros na gestão econômica territorial das localidades e suas potencialidades endógenas.

\subsection{Agências de Desenvolvimento Regional da Espanha}

Ao abordarem o tema política industrial e desenvolvimento regional, Santos, Amador \& Hernández (1995) apontam o papel e a importância fundamental que teve na política de promoção industrial da Espanha a figura da Agência de Desenvolvimento Regional - ADR.

A orientação básica de uma ADR espanhola é o estímulo à formação do potencial de capital endógeno da região para criar condições adequadas para o desenvolvimento, isto norteia todas as funções e atuações de uma Agência de Desenvolvimento Regional.

$\mathrm{Na}$ Espanha, as ADRs são instrumentos de intervenção pública na promoção industrial e, apesar de terem, predominantemente capital público, funcionam com autonomia sob os regulamentos do direito privado, participando de sua direção organizações empresariais, como Câmara do Comércio e Associações Industriais e Comerciais.

Cada uma das ADRs, como ferramenta de política econômica na Espanha, tem seus objetivos, instrumentos e modelo de organizacional. O objetivo básico, criar condições de desenvolvimento em sua região, tem como campo central de atuação o apoio à inovação e ao desenvolvimento tecnológico.

Uma ADR na Espanha visa potencializar a capacidade de inovação da região mediante duas linhas de atuação: a modernização da estrutura produtiva e a diversificação territorial e setorial do tecido industrial. 
II. Desenvolvimento Econômico Local

A consolidação do ambiente favorável a esta potencialização, segundo Santos, Amador \& Hernández, seria obtida com "ações inter-relacionadas como: corte horizontal na recepção, tratamento e difusão de informações; desenvolvimento tecnológico; desenho de novos produtos; pesquisa e acesso a novos mercados".

Os pesquisadores acreditam que estas ações têm potenciais de crescimento entre as pequenas e médias empresas, sendo elas, na verdade, o objeto dos serviços a serem prestados pelas ADRs. Para eles, a Agência deve elaborar uma organização descentralizada, tanto funcional quanto territorial, considerando a variável espacial como uma das mais importantes em sua concepção.

Santos, Amador \& Hernández consideram básico o conceito de proximidade e acessibilidade ao serviço ofertado quando se tem por objetivo a promoção da pequena e média empresa. Segundo eles, há necessidade de se partir da estrutura existente considerando os pontos fracos (financiamentos, inovação e comercialização) para aproveitar a capacidade interna de cada espaço regional e dinamizar o que existe por meio de ajustes estruturais locais.

Os instrumentos utilizados pela ADR espanhola, apontam os autores da pesquisa, são:

\section{Incentivos Financeiros}

- Subvenções para fins variados - desde cobrir parte do investimento até financiar a formação técnica da mão-de-obra ou a descentralização da atividade produtiva;

- Empréstimos e créditos com juros preferenciais para aumento de capital fixo das empresas;

- Avais e garantias para facilitar o acesso a fontes externas de financiamento;

- Participações em capital;

- Capital de risco.

\section{Incentivos Não-Financeiros}


II. Desenvolvimento Econômico Local

- Provisão de infra-estruturas físicas (adequação do espaço territorial para as atividades econômicas);

- Prestação de informação (acesso a mercado, novas tecnologias, fundos, etc.; intermediação e aproximação entre empresas; assessoria a gestão empresarial; pesquisa e fomento a introdução de novas tecnologias; formação e qualificação de mão-de-obra técnica; promoção e marketing no nível local e global);

- Instrumentos de Nova Configuração (estruturas operacionais responsáveis pela coordenação e implantação de todos os incentivos da política industrial descrita), seriam eles:

- Institutos Tecnológicos - devem ser situados em áreas com um denso tecido de pequenas e médias empresas do mesmo setor;

- Parques Tecnológicos - devem receber empresas em setoreschave de tecnologia de ponta e atuar como centros de difusão;

- Centros de Inovação - incubadoras industriais, onde as novas empresas recebem tutela e transferência de tecnologia;

Notando que estes instrumentos têm um caráter universal no mundo industrial desenvolvido, Santos, Amador \& Hernández notaram a singularidade destes instrumentos na sua organização e no funcionamento, quando devem atuar em rede. Para tornar suas funções eficazes, recomendam eles:

a. A interação entre os componentes ou instrumentos para uma atuação coordenada que esteja sob orientação de uma mesma ADR;

b. A descentralização tanto territorial como setorial dos diferentes instrumentos facilitando o acesso das pequenas e médias empresas em todo a Espanha;

c. A retroalimentação através da participação dos agentes econômicos nos diferentes instrumentos que permita um aperfeiçoamentos das ferramentas aplicadas. 
II. Desenvolvimento Econômico Local

Santos, Amador \& Hernández concluem afirmando: “O critério básico orientador da política desempenhada pelas ADRs é o mercado e as transformações que ele introduz na organização do sistema econômico. O mercado marca a pauta e as diretrizes a que devem se adequar todo tipo de indústria para manter sua competitividade. Esta realidade mutante faz com que a política industrial também o deva ser".

\subsection{Associação Européia de Agências de Desenvolvimento -}

\section{EURADA}

Vítor Soares, vice-presidente da Associação Européia de Agências de Desenvolvimento - EURADA, órgão da Comunidade Européia que congrega 143 estruturas regionais de desenvolvimento econômico em todos os países da Europa, identifica uma dificuldade tradicional nas várias regiões européias: a cooperação interinstitucional, resultado da não diferenciação clara entre o nível políticoinstitucional e o nível técnico-institucional. Diz ele:

"O nível político-institucional é de fato o plano em cada instituição, seja ela nacional, local ou regional, tem de exercer a legitimidade social que lhe é conferida no contexto dos seus objetivos globais e específicos, não esquecendo o estabelecimento, quando possível e desejável, de acordos interinstitucionais do mesmo nível de ação ou de níveis complementares.

O nível técnico-institucional, no contexto das relações interinstitucionais do território, é determinante para a implementação dos processos de parceria no nível local e regional, identificando projetos concretos que pela sua natureza ou fins, potencializem o desenvolvimento integrador de uma dada zona geográfica”.

É deste aspecto que surgiram na última década nos países da União Européia, e hoje também nos países da Europa Não-Comunitária, bem como na América do Norte, as chamadas Agências de Desenvolvimento.

Para que estas se materializem numa organização própria e independente, as autoridades locais e regionais devem estar fortemente ligadas com outros atores, sociais e econômicos, de modo a possibilitar pesquisas, projetos de serviços e informação orientados para objetivos estratégicos sociais e 
II. Desenvolvimento Econômico Local

econômicos, que podem tornar um dado território pró-ativo, em relação ao governo central, e competitivo face a outras regiões nacionais e internacionais ${ }^{1}$.

\subsubsection{Agência de Desenvolvimento como Observatório}

Segundo Soares, uma agência de desenvolvimento local deve estar na posição de vigilante sobre a economia, sobre a vida social e cultural de uma região, estando inserida sob todos os aspectos na comunidade, e exercer um papel de observatório, onde necessita:

- uma compreensão profunda dos problemas e potenciais de uma dada área geográfica;

- uma forte habilidade de trabalhar com - significa não trabalhar para - as estruturas econômicas, políticas, culturais e sociais já existentes na região;

- uma padrão de intervenção realmente concreto e operacional, de modo que seu trabalho possa ser reconhecido como útil e importante econômica e socialmente, pelo estímulo à criação de novos empregos, de novas oportunidades e novas soluções.

Para isto, uma agência de desenvolvimento local tem de otimizar requisitos fundamentais, como:

- ser aceita e entendida pelas estruturas políticas;

- traduzir todos seus objetivos em projetos e atividades concretas;

- coordenar esforços com outras organizações regionais já existentes;

- mobilizar os recursos financeiros, públicos e/ou privados, necessários à sua estrutura básica e necessários à implementação de novos projetos;

- ter autonomia e independência necessárias para tomar suas próprias decisões no contexto interinstitucional;

- ter um empenho e capacidade do pessoal técnico para obter resultados concretos. 
II. Desenvolvimento Econômico Local

\subsubsection{Classificação das Agências da EURADA}

Pode-se estabelecer, de acordo com Soares, uma classificação para distinguir os diferentes tipos de agências de desenvolvimento regional da EURADA, dividindo-as por origem e por atividade.

Por origem elas podem ser reconhecidas como:

- Agências fundadas por governos centrais;

- Agências existentes dentro de autoridades locais e regionais;

- Agências fundadas pelas autoridades locais e regionais;

- Agências independentes fundadas por parcerias público-privadas.

A análise de Soares aponta vantagens e desvantagens em todos os tipos de agências:

1. no caso de agências criadas pelo governo central, se por um lado contam com recursos financeiros, elas não dão ênfase a processos pois, trabalham com produtos e buscam resultados a curto prazo, descuidando das metas de longo prazo.

2. as agências incorporadas em estruturas governamentais dirigidas por autoridades regionais ou locais demonstram um bom conhecimento das realidades regionais. Mas, dependentes de uma hierarquia política não conseguem agilidade devido aos trâmites burocráticos o que as torna lentas para operacionalizar projetos de desenvolvimento econômico, que possuem uma forte dinâmica de mercado.

3. as agências criadas por iniciativas governamentais locais, possuindo independência para ações concretas, podem tomar decisões mais rápidas e por estarem mais próximas dos corpos dos executivos regionais são, entre as estruturas públicas, as que melhor oferecem condições de sucesso.

4. as agências sustentadas por parcerias público-privadas, entretanto, são as que possuem melhor habilidade para combinar pontos de vista e de interesse dos setores público e privado. Esta avaliação é válida tanto para a adoção de metodologias que irão dar suporte ao desenvolvimento de projetos, quanto no estabelecimento de objetivos e metas. 
II. Desenvolvimento Econômico Local

A visão de uma coordenação entre a capacidade institucional do setor público com as aptidões operacionais do setor privado, pode ser um modelo alternativo real para implementar e promover modelos de desenvolvimento econômico, regional e local. Esta idéia se reforça devido às tendências econômicas, sociais e políticas que têm em estruturas como estas perspectivas de melhor atuação e distribuição do crescimento das atividades econômicas globais.

Quanto às atividades, elas podem ser classificadas como:

- Agências estratégicas;

- Agências operacionais globais;

- Agências operacionais setoriais.

As estratégicas, conforme a visão de Soares, trabalham basicamente com a obtenção, tratamento e difusão de informação sustentada em bases de dados sociais e econômicos, oferecendo estudos de pesquisas setoriais e globais em todos aspectos, promoção integrada regional para o mercado nacional e internacional, apoio e suporte a pequenas e médias empresas, estimulando o potencial endógeno de desenvolvimento regional.

As operacionais globais têm como objetivo o estabelecimento, a promoção e a divulgação dos projetos de desenvolvimento intersetorial. Elas agem, muitas vezes ou em parceria ou, mesmo, dentro de agências estratégicas, em projetos específicos de intervenção para a reestruturação de redes econômicas, envolvendo as pequenas e médias empresas e o setor público, habitualmente no papel de animadora do processo de aproximação entre os setores.

As setoriais são estabelecidas com o objetivo de promover determinado setor existente na região, englobando focos tão distintos quanto emprego e cultura, por exemplo. Ou comércio varejista e artesanato. Elas promovem projetos específicos para atender um setor ou um conjunto de setores tendo como meta as atividades econômicas ou sociais em uma determinada área. 
II. Desenvolvimento Econômico Local

\subsubsection{Premissas para o Sucesso de uma Agência de}

\section{Desenvolvimento}

Da experiência de Soares na EURADA, a criação, implementação e operação bem-sucedida de uma agência de desenvolvimento local e/ou regional observaram as seguintes premissas ${ }^{2}$ :

a. o local não é o oposto do regional, são duas áreas de complementaridade funcional, embora com especifidades próprias;

b. as agências de desenvolvimento devem ser entendidas como empresas de desenvolvimento, no sentido da descoberta de áreas de intervenção potencializadoras de qualidade econômica interdisciplinar;

c. as parcerias a serem estimuladas devem ser evolutivas - quer territorialmente, quer no que diz respeito aos parceiros, flexíveis onde se tenha ao final um projeto estruturado, nos seus aspectos jurídicos, econômicos e organizacionais, e com análise da sua viabilidade econômica e funcional no contexto da validação interinstitucional a que se propõe.

A criação de uma agência de desenvolvimento local e/ou regional, considera Soares, é uma atitude que implica grandes mudanças, tanto no nível das relações interinstitucionais regionais, pelo posicionamento que a nova estrutura toma, como no nível técnico pelas inovações introduzidas. Porém, deve-se cuidar para que isto não implique em substituição ou sobreposição das competências regionais já instaladas e em funcionamento.

Entretanto, uma agência de desenvolvimento, eminentemente um empreendimento baseado em planos estratégicos, é apenas ente retórico até que incorpore as atividades para as quais foi idealizada. E, mesmo após suas funções estarem implantadas, exige-se dela uma permanente reformulação organizacional para enfrentar as mudanças de percurso, uma situação previsível quando se trabalha com ações estratégicas, as quais estão em constante avaliação.

Diz, ainda, Vítor Soares: 
II. Desenvolvimento Econômico Local

"Estes conceitos não devem ser meramente filosóficos ou teóricos, mas $\operatorname{sim}$ verdadeiros conceitos metodológicos e operativos. Sem uma clara definição de um plano de atividades a curto e médio prazo, o futuro da agência será, sem dúvida, um ponto de interrogação.

Não é suficiente estar de acordo sobre a idéia ou sobre os objetivos principais, todos devem estar conscientes das metas concretas que a nova estrutura pretende atingir".

\subsubsection{Organização de uma Agência da EURADA}

$\mathrm{Na}$ Eurada, Soares constatou que existem variações quanto a uma estrutura operacional de uma agência de desenvolvimento local. Mas, de forma geral, um papel fundamental é atribuído ao diretor geral, o executivo da agência. Ele se responsabiliza pelas metas operativas aprovadas pela administração, uma espécie de conselho superior. Neste conselho superior figuram representantes da sociedade abrangida pela agência, tais como: políticos representantes dos municípios e região; lideranças políticas, comunitárias e privadas; representantes de empresas, sindicatos, bancos, universidades, institutos, setores das atividades produtivas; etc. Este conselho tem, entre outras responsabilidades legais, a função de aprovar os planos estratégicos e o orçamento da agência, e acompanhar o andamento das etapas dos projetos aprovados. Segundo ele, as agências européias estão normalmente estruturadas nos seguintes corpos legais:

- Assembléia Geral;

- Presidente e Vice-Presidente;

- Administração;

- Conselho Fiscal;

- Diretor Geral.

A Assembléia Geral reúne periodicamente os sócios e/ou acionistas fundadores da agência para a eleição do Presidente e seu Vice, e também para indicação dos membros da Administração e do Conselho Fiscal, que podem ou não serem nomes escolhidos entre os sócios e/ou acionistas fundadores. O Diretor Geral, normalmente indicado pelo Presidente eleito, passa necessariamente pela aprovação da Assembléia Geral ou da Administração. 
II. Desenvolvimento Econômico Local

A estrutura das agências européias conta ainda com os Comitês ou Grupos de Trabalho que são constituídos especialmente para tratar de assuntos pontuais e funcionam com órgãos consultivos formados por especialistas das áreas destes assuntos.

Soares acredita que a atuação do Diretor Geral é vital para a agência de desenvolvimento local, pois, estas contam normalmente com pequenas estruturas técnicas em seu início, e para isto o Diretor Geral, evitando-se ser um cargo de confiança, deve ter um excelente perfil profissional, contando com as seguintes características:

a. prestígio técnico e de gestão na região e em relação às instituições;

b. conhecimentos profundos sobre os fatores sociais, econômicos e culturais da região;

c. bons conhecimentos sobre os fatores nacionais e internacionais;

d. bons conhecimento sobre o estilo de funcionamento de instituições e empresas da região, a chamada "cultura de empresa e organização";

e. modo de pensar interdisciplinar, com capacidade de integrar vários dados de diferentes campos de trabalho, numa abordagem comum;

f. uma enorme capacidade de liderança, sem perder a perspectiva determinante de constituição de espírito de equipe dentro do pessoal técnico;

g. uma excelente capacidade para promover projetos, procurar parceiros, identificando objetivos e possibilidades comuns;

h. um bom conhecimento sobre as fontes de informação e de financiamento que possam ser usadas como facilitadoras de atividades da agência;

i. prática de utilização de perfis e características de outras pessoas, de modo a compor uma equipe complementar, como base para alcançar um objetivo comum - o sucesso da agência, é o sucesso da região; 
II. Desenvolvimento Econômico Local

j. total confiança e responsabilidade por parte do Conselho de Administração na escolha da equipe técnica e administrativa.

A capacidade técnica e administrativa do Diretor Geral, assegura Soares, vai lhe dar confiança para montar uma equipe de trabalho altamente qualificada que deve possuir as seguintes características:

a. capacidade de execução de pequenos projetos de desenvolvimento, individualmente e em grupo, com resultados sociais e econômicos, que irão funcionar como efeito demonstrativo e catalisador de modelos de desenvolvimento sistêmicos;

b. capacidade de assumir uma atitude não-burocrática em relação à realidade organizacional da agência, trabalhando por objetivos e avaliando o impacto dos seus resultados;

c. construir um corpo conceptual básico, comum a toda equipe, e promover neste a mesma noção operativa dos objetivos de trabalho;

d. implementar a necessidade de formação contínua, de inovação permanente e de um rigor real;

e. encontrar a noção de marketing de equipe, de modo a que, e como conseqüência, a agência tenha credibilidade no seio das entidades e organizações com as quais se relaciona.

Soares salienta, ainda, que não há um enfoque disciplinar único para o corpo técnico da agência, pois as atividades são voltadas para projetos que exigem um enfoque multidisciplinar, desta maneira, assim é encontrada uma grande variedade de qualificações acadêmicas nas equipes técnicas das agências da EURADA.

\subsection{Experiência Brasileira das ADLs em São Paulo}

Em Junho de 1997, o Governo do Estado de São Paulo, através de sua Secretaria de Ciência, Tecnologia e Desenvolvimento Econômico - SCTDE -, apresentou o Manual para Implantação das Agências de Desenvolvimento 
II. Desenvolvimento Econômico Local

Econômico Local - ADLs - que, junto com outras propostas, visando aumentar a competência de desenvolvimento econômico das regiões do estado de São Paulo, fazia parte do plano "Estratégia Competitiva do Estado", elaborado com assessoria da Divisão de Economia e Engenharia de Sistemas - DEES - do Instituto de Pesquisas Tecnológicas - IPT.

\subsubsection{Missão e Objetivos de uma ADL}

Segundo o Manual, a implantação de uma Agência de Desenvolvimento Econômico Local (ADL) deveria ter como missão a promoção do desenvolvimento econômico de um determinado município. E, para isto, a ADL teria como objetivos:

- manter e estimular os atuais empreendimentos econômicos do município;

- atrair novos investimentos para o município

Desta forma caberia à ADL: "coordenar os agentes locais, estimular parcerias, fornecer informações e servir como interlocutor único do município com as entidades públicas e privadas de fomento para viabilizar a adoção de medidas práticas que promovessem o desenvolvimento econômico local".

\subsubsection{A ADL como uma ONG}

Uma Organização Não-Governamental (ONG), com o amparo do governo municipal e com o apoio técnico, político e financeiro da iniciativa privada local e outras entidades da sociedade civil (Universidades, Escolas Técnicas, Associações Comerciais e Industriais, etc.), seria o formato ideal para a ADL.

Segundo consultores e pesquisadores do IPT, esta organização deveria ser caracterizada como uma entidade civil, sem fins lucrativos e de utilidade pública, onde pudessem se associar pessoas físicas e jurídicas. Sua autosustentação deveria ser garantida através de contribuições regulares de seus associados, receitas provenientes de prestação de serviços (p.ex., através da organização de eventos, seminários, publicações, etc.), de convênios com entidades de fomento (p.ex., Banco Mundial, BNDES, SEBRAE, SCTDE, etc.) e doações realizadas por pessoas físicas ou jurídicas. 


\subsubsection{Beneficiários de uma $\mathrm{ADL}$}

O Manual via nesta estrutura a possibilidade de beneficiar:

a. governo municipal, por dispor de um instrumento para coordenar parcerias entre os agentes locais e as entidades de fomento, visando a adoção de medidas práticas que promovam o desenvolvimento econômico local;

b. as empresas já instaladas, por contar com um canal para encaminhamento de idéias, demandas e projetos específicos junto ao setor público e órgãos de fomento;

c. potenciais investidores, por ter acesso facilitado às informações e aos diversos agentes locais através de um interlocutor único (a ADL).

d. as instituições de ensino, por facilitar a integração de seus pesquisadores e alunos no processo de desenvolvimento da comunidade;

e. as organizações de fomento, por identificarem com mais facilidade as demandas específicas de cada região e obterem suporte para a realização de projetos bem fundamentados;

f. governo do estado, por contar com um instrumento de desenvolvimento econômico descentralizado, nos diversos municípios do estado; e

g. a comunidade local como um todo, por contar com um espaço para a reflexão de suas potencialidades, articulação de parcerias e por participar de ações concretas que visam melhorar a sua qualidade de vida.

\subsubsection{Constituição de uma ADL}

Entre as estrutura possíveis para criar a ADL, a mais indicada para a promoção do desenvolvimento local seria uma agência municipal de constituição mista, com a presença dos setores privado e público. Ela teria como principal vantagem a possibilidade de desempenhar tarefas delegadas pelos governos locais com um nível de agilidade equivalente ao das entidades privadas. 
II. Desenvolvimento Econômico Local

Para seu sucesso, indicava o IPT que a ADL deveria desfrutar do apoio técnico, político e financeiro de ambos os setores, público e privado. A composição de ADL mais eficiente seria aquela em que houvesse uma participação equilibrada entre estes setores, sem predominância de qualquer um de seus associados no processo de tomada de decisões. Suas ações deveriam se fundamentar sempre num contínuo processo de interação, consulta e busca do consenso entre as partes que compõem a ADL. Assim, uma ADL deveria contar com:

Setor público - contribuindo e implementando melhorias nas áreas de infra-estrutura, desburocratização, uso e ocupação do solo, tributos, financiamento, zoneamento, fornecimento de licenças e outros incentivos.

Setor Privado - contribuindo nas áreas de planejamento estratégico, marketing, informações, habilidades especializadas e demais fatores envolvidos na avaliação e expansão dos negócios.

"Conhecimento" - contribuindo com programas de modernização gerencial e tecnológica e dando apoio ao estabelecimento de novos empreendimentos ou à ampliação dos já existentes.

\subsubsection{ADL Intermunicipal}

Os pesquisadores da DEES do IPT viam, ainda, a possibilidade da Agência de Desenvolvimento Econômico Local ter uma atuação intermunicipal. Desta maneira, embora, a ADL devesse ser um organismo com atuação voltado basicamente para as atividades sócio-econômicas de um município específico, considerava o Manual do Plano Estratégia Competitiva do Estado que, se individualmente cada município de uma mesma sub-região se apresentasse incapacitado de constituir sua própria $\mathrm{ADL}$, uma configuração de $\mathrm{ADL}$ poderia envolver uma estrutura consorciada de prefeituras e representantes empresariais desta sub-região como um todo.

$\mathrm{Na}$ ADL intermunicipal, uma estrutura consorciada teria responsabilidade pela articulação dos interesses representativos do conjunto de prefeituras e dos setores produtivos dos municípios associados. A diferença é que suas ações se estenderiam sobre o conjunto dos municípios associados. 


\subsubsection{Atividades de uma ADL}

Para atingir seus objetivos, o plano da SCTDE/SP previa uma série de atividades em áreas como a de planejamento, promoção de eventos, serviços às empresas, formação de recursos humanos, etc. que deveriam fazer parte da atuação da ADL. Por exemplo:

\section{a. Planejamento e marketing municipal}

- auxiliar a prefeitura municipal na elaboração e execução de um PDM, Plano de Desenvolvimento Municipal ${ }^{3}$, bem como em suas atualizações periódicas;

- identificar tendências e levantar as potencialidades e as vocações da região que possam ser exploradas para a promoção do desenvolvimento econômico local, dando preferência às atividades de maior valor agregado e em processo de expansão;

- realizar estudos sobre as oportunidades de exportação, visando promover e direcionar a internacionalização das empresas locais;

- realizar estudos sobre a viabilidade da criação de fundos de capital de risco para investimentos locais em negócios com alto poder de expansão;

- preparar e editar monografia sobre a cidade e sua região, destacando os aspectos positivos do município e seus desafios;

- elaborar um plano de marketing municipal com promoção nos níveis regional, estadual, nacional e internacional das oportunidades de negócios da região, valendo-se de recursos da mídia tradicional e dos novos meios de comunicação eletrônicos;

- organizar missões, feiras e rodadas de negócios para promoção do município e suas atividades produtivas.

\section{b. Serviços às empresas do município}

- elaborar um banco de dados municipais, centralizando as informações relevantes para o desenvolvimento que estejam dispersas nos diversos órgãos da administração local, 
II. Desenvolvimento Econômico Local consolidando dados locais sobre infra-estrutura sócio-econômica, disponibilidade de linhas de financiamento, incentivos fiscais, rede de parceiros potenciais, oportunidades de negócios, serviços de C\&T, serviços disponíveis às pequenas e médias empresas, etc.;

- informatizar e disponibilizar o banco de dados municipais à sociedade, visando o atendimento da demanda por informações do local, para tornar mais transparente as oportunidades de negócios que existem no município e para agilizar os processos de decisões, tanto no âmbito público quanto no privado;

- apoiar as empresas já instaladas na região, auxiliando-as nas resoluções de problemas de natureza mercadológica, administrativa, econômico-financeira, tecnológica, ambiental ou político-institucional, de forma a aumentar sua competitividade;

- dar assistência aos empresários interessados em investir na região, em questões como locação de projetos, obtenção de recursos, facilidades energéticas, de comunicação, de transportes, ambientais e tecnológicas;

- receber e acompanhar investidores em visita ao município, com roteiros de visita e agenda previamente preparados;

- estimular a criação de pequenas e médias empresas, através de parcerias com o SEBRAE;

- fomentar a criação de Empresas de Participação Comunitária EPC -, incentivando o desenvolvimento de uma cultura empreendedora na comunidade local;

- participar da instalação de Incubadoras de Empresas;

- estimular a implantação de Condomínios Industriais e de Serviços - CIS - ;

- realizar pesquisa para levantar a demanda e a oferta de imóveis que possam ser transformados em CIS; 
II. Desenvolvimento Econômico Local

- apoiar a criação de centros de serviços laboratoriais e centros de Pesquisa e Desenvolvimento $(\mathrm{P} \& \mathrm{D})$ especializados, vinculados às principais atividades econômicas locais.

\section{c. Recursos humanos do município}

- adotar programas de qualificação e aperfeiçoamento da mão-deobra em todos os níveis;

- promover cursos de aperfeiçoamento da capacitação empresarial local, em parceria com o SEBRAE;

- participar de projetos de estímulo à geração de emprego, em parceria com o Ministério do Trabalho, a Secretaria Estadual do Trabalho e Emprego e sindicatos de trabalhadores (p. ex., Banco do Povo, etc.).

\section{d. Outras atividades}

- estimular o aprimoramento das parcerias já existentes e a realização de novas parcerias entre os agentes locais e instituições de fomento ao desenvolvimento;

- participar de projetos de integração social e de proteção ao meio ambiente, visando elevar o nível de qualidade de vida da comunidade local;

- identificar outras demandas de serviços que possam ser oferecidos pela própria ADL ou que esta possa contratar junto a terceiros;

- promover integração com os demais conselhos estaduais de atuação no âmbito municipal (por exemplo: de emprego, agricultura, da criança e do adolescente, etc.);

- manter contato permanente com órgãos estaduais, federais e internacionais de apoio ao desenvolvimento (por exemplo: Banco Mundial, BNDES, FIESP, SEBRAE, etc.). 
II. Desenvolvimento Econômico Local

\subsubsection{Fatores Críticos para o Sucesso da ADL}

O Manual da SCTDE/SP indicava também alguns fatores críticos para que uma ADL fosse bem-sucedida em suas ações, recomendando que a organização tivesse:

- autonomia e flexiblidade;

- poderes e responsabilidades significativos delegados por seus associados;

- estrutura enxuta e qualificada (staff de no máximo 3 pessoas), recorrendo à terceirização quando necessário;

- aporte adequado de recursos físicos e financeiros, para cobrir despesas de manutenção e operação das atividades da ADL;

- comprometimento do setor público e da iniciativa privada local, com recursos técnicos e financeiros e ativa participação nos grupos de trabalho;

- constante busca de consenso entre os agentes envolvidos; e

- um número de associados não muito extensivo, para facilitar o consenso.

\subsubsection{Etapas para Implantação de uma ADL}

O Manual elaborado pelo IPT para a SCTDE/SP estabeleceu, ainda, as etapas fundamentais para implantação de uma ADL:

\section{Etapa 1 - Definição do agente promotor da ADL}

No processo de implantação da ADL seria fundamental o papel da prefeitura municipal. Ela deveria indicar um responsável direto, o agente promotor da ADL, que teria como atribuições: identificar, estimular e facilitar a participação organizada dos principais agentes econômicos locais no processo de implantação da ADL. O agente promotor poderia ser o próprio prefeito ou alguém indicado por ele e, para ser bem-sucedido na promoção da ADL, deveria apresentar as seguintes características desejáveis: amplo conhecimento das instituições e personalidades locais; boa desenvoltura entre os diversos grupos locais; e grande poder de articulação. 
II. Desenvolvimento Econômico Local

Etapa 2 - Articulação dos agentes locais em torno de uma pauta de discussões

Entre os agentes econômicos locais relevantes para o desenvolvimento que deveriam ser contatados pelo agente promotor da ADL estariam as lideranças empresariais, acadêmicas e políticas da região. Após a identificação daqueles agentes relevantes, caberia ao agente promotor articulá-los em torno de uma pauta de discussões a ser levantada, com questões de caráter estrutural, consideradas de forma consensual como questões que precisariam ser prioritariamente resolvidas para promover o desenvolvimento do município (p.ex., melhoria na qualidade da mão-de-obra, no sistema de transportes, na dotação de "equipamentos urbanos", reestruturação da ocupação do solo urbano, etc.). A busca do consenso na elaboração desta pauta deveria favorecer a formação de um clima propício à cooperação.

\section{Etapa 3 - Criação do comitê pró-ADL}

Uma vez definida a pauta de discussões, sob a coordenação do agente promotor, deveria a Prefeitura constituir um comitê executivo pró-ADL com a participação daquelas lideranças políticas, acadêmicas e empresariais consultadas que tivessem demonstrado interesse em participar da formação da ADL. Em essência, o comitê executivo pró-ADL se constituiria na base dos sócios fundadores da ADL.

\section{Etapa 4 - Elaboração do estatuto social da ADL}

Com o auxílio de um advogado ou contador, caberia ao comitê próADL redigir um Estatuto Social levando em consideração as condições específicas da região, dos sócios fundadores e dos objetivos que se pretendessem atribuir à ADL. Neste estatuto deveriam constar definições quanto aos objetivos da ADL, natureza, sede, foro, finalidades, patrimônio, contribuições, responsabilidades dos associados, estrutura organizacional desejada, etc.

\section{Etapa 5 - Constituição da ADL como entidade civil}

Para formalizar a constituição da ADL, deveria ser realizada uma Assembléia Geral de inauguração, com a presença dos sócios fundadores, para 
II. Desenvolvimento Econômico Local

aprovar o Estatuto Social da mesma. Em seguida deveriam ser providenciados alguns registros obrigatórios, tais como:

- registro do Estatuto Social na Junta Comercial;

- requerimento de registro na Receita Federal (CGC);

- alvará de funcionamento da prefeitura;

- registro no INSS; e

- impressão de notas físcais de serviços.

Etapa 6 - Definição da diretoria e da estrutura departamental inicial da ADL

Também em Assembléia Geral, os sócios fundadores deveriam eleger um número específico de representantes para compor o Conselho Superior da ADL. Uma das atribuições iniciais do Conselho Superior seria eleger a Diretoria Executiva da ADL.

A diretoria, por sua vez, deveria submeter àquele conselho uma proposta de Regimento Interno, especificando nele a estrutura departamental inicial da ADL.

Para se definir a estrutura departamental ou os grupos de trabalho da ADL, dever-se-ia ter como parâmetros:

- conjunto de temas relevantes sugeridos pela pauta de discussões; e

- a definição dos recursos técnicos e financeiros disponibilizados pelos sócios fundadores.

\section{Etapa 7 - Preparação para o início das operações}

Após a definição da diretoria, esta deveria realizar três conjunto de atividades, de forma simultânea, para que a ADL pudesse dar início à suas operações:

- Montagem das condições operacionais iniciais da ADL: contratação do staff e montagem da infra-estrutura operacional inicial (escritório, secretária, boy, aparelhos de comunicação, etc.); 
II. Desenvolvimento Econômico Local

- Reconhecimento da ADL como entidade de utilidade pública: processos simultâneos e independentes de reconhecimento da ADL como entidade de utilidade pública nos três níveis de governo: municipal, estadual e federal;

- Elaboração de um Plano de Desenvolvimento Municipal (PDM): o PDM, que deveria ser elaborado com a participação ativa dos sócios fundadores, em grupos temáticos de trabalho, ampliando e aprofundando as discussões em torno dos temas básicos levantados na pauta de discussões inicial. A elaboração do PDM e suas atualizações periódicas deveriam servir de base para orientar as ações da ADL no longo prazo e, caso se mostre necessário, para remodelar sua estrutura de operações.

\subsubsection{Parceiros Potenciais para a ADL}

Os técnicos e consultores do IPT sugeriram alguns parceiros potenciais para a operação de uma ADL:

a) SCTDE (Secretaria de Ciência, Tecnologia e Desenvolvimento Econômico): financia parcialmente serviços técnicos especializados de apoio ao desenvolvimento regional, dentro do Programa de Apoio ao Desenvolvimento dos Municípios (PRODEM). Entre os serviços cobertos pelo PRODEM estariam: assessoria para elaboração de Planos de Desenvolvimento Municipal, realização de diagnósticos e estudos de caráter sócioeconômico e ambiental, estudos de viabilidade econômica de projetos (de condomínios industriais, incubadoras, etc.), apoio à implantação de ADL, etc.;

b) Estatais (CESP, CPFL, ELETROPAULO, CETESB, SABESP, FEPASA, etc.): contribuindo através de uma desburocratização dos procedimentos no atendimento de infra-estrutura para empreendimentos como os de Condomínios Industriais e de Serviços, além disso realizariam levantamentos dos imóveis próprios e terrenos que se encontrassem ociosos, cujo uso poderia ser reconvertido para a implantação de Condomínios Industriais; 
II. Desenvolvimento Econômico Local

c) CEPAM (Centro de Estudos e Pesquisas de Administração Municipal), que poderia prestar serviços como: diagnósticos econômico-financeiros, diagnósticos das receitas municipais, das despesas municipais; organização de cadastros técnicos, físicoterritoriais, cadastros de informações rurais, de informações sócioeconômicas, de equipamentos e serviços urbanos; assistência técnica aos municípios nas áreas jurídica, de modernização administrativa, formação de recursos humanos, políticas de desenvolvimento urbano, rural e ambiental; inserção de homepage de divulgação do município na Internet; etc.;

d) SEBRAE (Serviço de Apoio às Micro e Pequenas Empresas): que disponibilizaria assessoria na abertura de pequenas empresas, na implantação de Empresas de Participação Comunitária (EPC), em incubadoras de empresas, Condomínios Industriais e de Serviços (CIS), cursos de formação e treinamento de pequenos empresários, auxílio no levantamento de dados e identificação do potencial e oportunidades de desenvolvimento nos municípios;

e) FIESP (Federação das Indústrias do Estado de São Paulo): que poderia promover a articulação de contatos com os diversos sindicatos patronais do estado de São Paulo, auxiliar na organização de feiras e missões ao exterior, etc.;

f) FINEP (Financiadora de Estudos e Projetos): ofereceria fundos e programas voltados para pesquisa (básica e aplicada), desenvolvimento experimental e infra-estrutura de P\&D (Pesquisa e Desenvolvimento);

g) Banco do Brasil: poderia disponibilizar linhas de financiamento para projetos de investimento e capital de giro associado a empreendimentos de micro e pequenas empresas, visando a geração de emprego e renda e a manutenção desses empreendimentos no município; 
II. Desenvolvimento Econômico Local

h) SENAI (Serviço Nacional de Aprendizagem Industrial): poderia oferecer cursos de capacitação, aperfeiçoamento e requalificação da mão-de-obra local.

\subsubsection{Avaliação da Implantação do Programa de ADLs}

Para implantação do Plano "Estratégia Competitiva do Estado" a SCTDE/SP promoveu seminários regionais em algumas regiões administrativas do estado de São Paulo visando despertar nas lideranças políticas e empresariais dos municípios paulistas a iniciativa para criação das ADLs. Além da apresentação dos instrumentos elaborados pelo IPT aos participantes dos seminários através de palestras que contavam com apoio do SEBRAE/SP, ainda houve a distribuição do manual editado e impresso pela Imprensa Oficial do Estado de São Paulo.

Entretanto os esforços da equipe da SCTDE/SP e dos técnicos e consultores do IPT não foram suficientes para uma adesão significativa das comunidades do interior de São Paulo. Assim, desde o lançamento do plano, ocorrido em outubro de 1996 até dezembro de 1997, apenas os municípios ${ }^{4}$ de Ourinhos, Santa Cruz do Rio Pardo, Agudos, Caçapava, Mogi Mirim, Itapiratiba, Suzano, Piracicaba, Jacareí, Registro, Águas de Lindóia e Limeira haviam demonstrado algum interesse em estruturar suas ADLs de acordo com as preconizações do plano da SCTDE/SP desenvolvido com assessoria do IPT.

Apesar da ineficácia dos seminários promovidos pelo governo do estado de São Paulo nas regiões paulistas, os eventos serviram para iniciar uma discussão entre aqueles municípios que haviam aderido ao plano visando aperfeiçoar os instrumentos apresentados. Neste sentido, no âmbito da SCTDE/SP, foi criado um comitê pró-forum das ADLs que deveria se encarregar de propor uma estratégia que ampliasse a ressonância da criação das agências de desenvolvimento local em uma escala maior do que aquela até então obtida.

Algumas iniciativas foram concretizadas, ainda pela SCTDE/SP, visando estimular a adesão de mais municípios ao plano. A mais importante foi o Programa de Desenvolvimento Regional (PRODEM) que deveria contar com recursos para a elaboração de diagnósticos locais e regionais, para fundamentar a 
II. Desenvolvimento Econômico Local

elaboração de planos de desenvolvimento municipal, um dos instrumentos previstos no Manual do plano.

A estrutura interna da SCTDE/SP, porém, não agilizou dentro de prazos exeqüíveis os processos de solicitação de recursos, que deveriam ser repassados ao IPT, para apoiar as iniciativas locais. Desta forma, enfraquecidas pela própria atuação do órgão estadual que havia estimulado as suas criações, as ADLs acabariam sendo desestimuladas a prosseguirem com seus projetos de desenvolvimento local.

Pode-se afirmar que com a descontinuidade da política de desenvolvimento econômico aplicada pela SCTDE/SP, o plano "Estratégia Competitiva do Estado" acabou por naufragar, desacreditado totalmente pelas lideranças locais.

As últimas informações levantadas junto à assessores da secretaria e técnicos do IPT constataram o abandono do PRODEM. Este programa que, se efetivado, seria um estímulo à formação de agências de desenvolvimento local, sofreu seu declínio por absoluta falta de recursos destinados pelo governo estadual.

Descarregar toda a culpa do insucesso do plano "Estratégia Competitiva do Estado" em cima de uma incompetência da SCTDE/SP ou do desinteresse do governo estadual de São Paulo seria uma injustiça além de um simplismo analítico.

Não se deve esquecer a insuficiência de articulação das lideranças políticas regionais empresariais para alavancá-lo financeiramente junto a outras fontes do governo federal e SEBRAE/SP, potencial parceiro para as ADLs tendo em vista seu programa, similar ao PRODEM, intitulado PRODER.

Também se denotou nas regiões e municípios a incapacidade para gerenciar o tráfego de múltiplas informações que permearia uma estrutura ambiciosa, porém necessária para implementar um programa abrangente de desenvolvimento local no estado mais desenvolvido do território brasileiro.

Em São Paulo, as ADLs, como concebidas pelos técnicos e consultores do IPT, seriam os instrumentos ideais para gerir a disponibilidade das variadas ferramentas de desenvolvimento possíveis e, assim, deveriam ter a 
II. Desenvolvimento Econômico Local

atenção dos poderes públicos executivos, legislativos e também das organizações empresariais na consolidação de suas atuações nas regiões e localidades.

A capacitação das instituições locais ${ }^{5}$ é fundamental no jogo político sem partidarismo e é pelo caminho da comunidade qualificada que podem surgir soluções para superar o desafio para empreender diretrizes como as pretendidas pelo governo paulista atual e estabelecidas por seu programa de governo ${ }^{6}$ :

- desconcentrar e descentralizar decisões, ações, responsabilidades e recursos; e

- mudar o papel do Estado de executor para coordenador ou articulador dos processos de parcerias.

A complexidade de ações estratégicas que estas metas requerem, ao mesmo tempo que foge a compreensão dos indivíduos comuns, exige de todos os cidadãos uma adesão e participação com a perfeita consciência da importância do seu papel neste processo. Evidencia-se, então, a agência de desenvolvimento local como agente viável na reflexão deste papel da comunidade e como ferramenta de ações que estão ao alcance dos cidadãos de uma localidade.

\subsection{Agência de Desenvolvimento Econômico de Ourinhos}

Trazendo o foco da discussão para uma questão pontual na experiência brasileira, este trabalho relata a seguir a experiência do autor na criação de uma agência de desenvolvimento econômico local na cidade de Ourinhos.

\subsubsection{Histórico}

Situada no sudoeste do estado de São Paulo, na divisa com o Paraná, a cidade de Ourinhos surgiu de uma vila de trabalhadores que em 1905 faziam o desmatamento das terras onde seriam assentados os trilhos da estrada de ferro Sorocabana, tornando-se ponto de parada obrigatório dos trens que serviam à região sudoeste do Estado.

Seu grande surto de desenvolvimento ocorreu a partir de 1922, com a construção da estrada de ferro que liga o Estado de São Paulo ao Paraná, tornando 
Ourinhos pólo econômico fundamental para o desenvolvimento do Norte do Paraná.

Como importante entroncamento rodo-ferroviário de cargas e, por sua localização estratégica, Ourinhos tem grande potencial para integrar toda a região sudoeste de São Paulo ao crescimento das atividades econômicas decorrentes do Mercosul, beneficiando as atividades econômicas regionais, além de revitalizar o município.

Esta perspectiva de retomada do desenvolvimento econômico local foi a grande motivadora para a criação da Agência de Desenvolvimento Econômico de Ourinhos - ADEO.

O passo inicial foi dado pelo empresário Ricardo Xavier Simões, sócio-diretor da empresa Delfim Verde - Empreendimentos Imobiliários S.A. que, através de sua empresa, logo depois das eleições municipais de 1996, patrocinou uma oficina de trabalho para discutir o desenvolvimento econômico do município, cujo fraco desempenho vinha prejudicando seus negócios imobiliários na cidade.

Esta oficina, coordenada por Ângela Fontes do Núcleo de Economia Local - DES - do Instituto Brasileiro de Administração Municipal - IBAM -, ocorreu entre os dias 30 de novembro e 05 de dezembro de 1996, e contou com a participação do prefeito eleito para a nova gestão municipal, que teria início a partir de $1^{\circ}$ de janeiro de 1997.

Além do prefeito de Ourinhos, desta Oficina de Trabalho participaram empresários locais, todos os secretários municipais e assessores, superintendentes de serviços municipais e consultores independentes, entre eles o autor desta tese.

\subsubsection{Oficina para Desenvolvimento Local de Ourinhos}

A Oficina de Trabalho, estruturada em quatro módulos, tinha como conteúdo programático:

- Primeiro, abordar as relações que se estabelecem entre: reestruturação econômica, planejamento estratégico, desenvolvimento econômico local e desenvolvimento urbano, cumprindo o papel de discutir, de forma prática e objetiva, as 
II. Desenvolvimento Econômico Local questões teóricas básicas consideradas como fundamentais para as discussões estabelecidas nos módulos seguintes;

- Segundo, trabalhar a necessidade de se ter um perfil econômico municipal atualizado, que disponibilize informações confiáveis, permitindo, além da aquisição de conhecimentos que ultrapassam a noção cotidiana da economia local, a formulação de estratégias de ação;

- Terceiro, discutir os aspectos tributários favoráveis ao desenvolvimento econômico local e suas interações com os instrumentos de fomento econômico e legislação diferenciada para micro e pequena empresas;

- Quarto, e último módulo, trabalhar as questões relacionadas com a formação da imagem municipal, através da discussão do marketing municipal, e as possibilidades de geração de emprego, trabalho e renda no nível local.

Segundo o relatório do IBAM, foram utilizadas técnicas de moderação, visualização e planejamento participativo durante as atividades. $\mathrm{O}$ instrumento didático principal utilizado foi o Guia de Desenvolvimento Econômico Local, publicação do próprio Instituto que, repassado aos participantes, serviu de base para a formulação de diretrizes para um programa de ação governamental, na área de geração de emprego, trabalho e renda, levando em consideração o conjunto dos atores sociais relevantes no cenário municipal de Ourinhos.

\subsubsection{Ourinhos e a Globalização}

O primeiro módulo da Oficina teve como objetivo básico reforçar os conceitos sobre as relações entre o micro e o macro, inserindo as questões locais no atual contexto de globalização da economia mundial.

Com este propósito, foi dado início aos trabalhos da Oficina com os participantes colocando suas percepções do impacto da globalização na vida da comunidade de Ourinhos, expondo as seguintes idéias:

- Aumento da mão-de-obra não qualificada 
- Mais recursos naturais para o lazer

- mundo está muito mais rápido que Ourinhos

- Encurta distâncias

- Obriga a repensar a cidade

- Cria novas oportunidades

- A globalização já traz implícita a urgência de mudanças, adiar decisões é perder

- Cria necessidade de atualizar as estruturas da cidade

- Falta de mão-de-obra qualificada - tradição, cultura e identidade

- Positivo. Acesso rápido ao conhecimento e oportunidades

- Demonstra necessidade imperiosa de correr atrás do prejuízo

- Ajuda na melhoria dos processos produtivos e na qualidade dos produtos/serviços

- Globalização afeta a cidade na medida em que falta sintonia com o processo

- Falta de preparo tecnológico para enfrentar a maior concorrência a nível mundial

- A percepção da solução globalizada faz o competidor mais forte

- A descontinuidade administrativa fragmenta as ações modernizadoras

- Com a globalização teremos que buscar mais tecnologia, mais qualidade para continuarmos competitivos

- Necessidade de definição da vocação do município

- Aspecto tributário - localização favorável ao estabelecimento de empresas, tendo como conseqüência mais empregos

- Exige uma qualificação do seu pólo ceramista - qualidade do produto 
II. Desenvolvimento Econômico Local

- Permite uma vantagem comparativa de sua qualidade de vida

- Resgata o seu posicionamento logístico para o desenvolvimento dos fluxos econômicos

- Possibilita intercâmbio e fortalece posicionamentos

\subsubsection{Problemas para Desenvolvimento de Ourinhos}

Dando prosseguimento ao primeiro módulo, a tarefa seguinte da Oficina foi discutir questões relacionadas com desenvolvimento econômico de Ourinhos, como: fatores locacionais, potencialidades locais, ameaças ao crescimento econômico, vantagens e desvantagens da cidade, etc.. Junto aos participantes, foi realizado um levantamento dos problemas vivenciados pelo Município no enfrentamento do desafio de assumir o desenvolvimento econômico de seu território.

Nesta etapa da Oficina, para obter este panorama da comunidade local, estabeleceu-se que cada participante escolheria três dos principais problemas que considerasse mais importantes no município, isto é, que dificultava o seu desenvolvimento econômico.

Alguns dos problemas de Ourinhos registrados pelos participantes foram:

- Falta de água (distribuição)

- Limpeza urbana deficiente

- Falta de tratamento de esgoto

- Falta de destinação do lixo

- Trânsito sem planejamento

- Acessos à cidade desprovidos de atratividade

- Transporte coletivo insatisfatório

- Falta de recursos humanos qualificados

- Poucos cursos superiores

- Baixo nível de escolaridade 
- Atendimento básico à saúde (programa) deficiente

- Atendimento hospitalar precário

- Saúde com atendimento insatisfatório

- Falta de planejamento estratégico

- Administração não modernizada

- Dificuldade de obtenção de recursos - financeiro, pessoal, organizacional e político

- Queda de arrecadação

- Mecanização da lavoura de cana

- Saída dos terminais de combustíveis

- Fechamento de cerâmicas

- Envelhecimento das atividades econômicas

- Pouca consciência sobre as vantagens naturais da cidade

- Falta de emprego

- Falta de postos de serviços

- Diminuição da geração de emprego

- Baixo nível de orgulho pela cidade

- Falta de identidade cultural

- Dificuldade na implantação de boas idéias (ceticismo)

- Indefinição da vocação econômica

- Falta de amor-próprio

- Falta de motivação à participação comunitária

- Falta de integração entre Prefeitura e Associações

\subsubsection{Equacionamento de Problemas de Ourinhos}

$\mathrm{Na}$ tarefa seguinte foi solicitado aos participantes que formassem três grupos e que cada um priorizasse um dos problemas apontados. 
II. Desenvolvimento Econômico Local

Inicialmente houve necessidade de relacionar os possíveis atores envolvidos, definindo a posição e importância de cada ator na busca de uma solução. 
II. Desenvolvimento Econômico Local

\section{Problema 1 - Mecanização da Cana}

O grupo 1 escolheu o problema da mecanização da cana, formando um quadro do atores envolvidos e os recursos possíveis de serem alocados:

\begin{tabular}{|l|l|}
\hline \multicolumn{2}{|c|}{ Quadro 5 } \\
\hline \multicolumn{2}{|c|}{ Mecanização da Cana na Região de Ourinhos } \\
\hline Atores & Recursos \\
\hline Usina São Luiz & Financeiro Político Infra-estrutura \\
\hline Associação de Plantadores & Político \\
\hline Sindicato dos Trabalhadores & Político \\
\hline P.M. Ourinhos/Secretaria Ação Social & Programa de Geração de Emprego \\
\hline Associação Comercial & Requalificação \\
\hline Escritórios de RH & Sondagem Cadastro de Profissionais \\
& Relocação \\
\hline
\end{tabular}

Fonte: Fontes (1997). 
II. Desenvolvimento Econômico Local

Problema 2 - Saídas dos Terminais de Petróleo

O grupo 2 compôs um quadro do possíveis atores e recursos alocáveis:

\begin{tabular}{|c|c|}
\hline \multicolumn{2}{|c|}{ Quadro 6 } \\
\hline \multicolumn{2}{|c|}{ Saída dos Terminais de Petróleo de Ourinhos } \\
\hline Atores & Recursos \\
\hline Prefeitura Municipal de Ourinhos & Político \\
\hline Secretaria de Finanças da P. M. Ourinhos & Logística \\
\hline $\mathrm{ACIO}$ & Articulação/Mobilização \\
\hline Sindicato dos Condutores Autônomos & Mobilização \\
\hline Sindicato dos Frentistas & Mobilização \\
\hline Sindicato dos Comerciários & Mobilização \\
\hline Bancos & Mobilização \\
\hline Rede Federal & Logística/Mobilização \\
\hline Fepasa & Logística/Mobilização \\
\hline Ministério das Minas e Energia & Informação \\
\hline Dersa & Informação/Logística \\
\hline Ministério da Fazenda & Estratégia \\
\hline Governo do Estado de São Paulo & Político \\
\hline Companhias de Petróleo & Informação/Logística \\
\hline Ministério da Indústria e Comércio & Estratégia \\
\hline
\end{tabular}

Fonte: Fontes (1997). 


\section{Problema 3 - Não Emprego}

O grupo 3 estruturou o problema do "não emprego", compreendido como a ausência de oferta para a incorporação dos jovens que são obrigados a largar os estudos e entrar no mercado de trabalho, formando um quadro do atores envolvidos e os recursos possíveis de serem alocados nesta questão:

\begin{tabular}{|l|l|}
\hline \multicolumn{2}{|c|}{ Quadro 7 } \\
\hline \multicolumn{2}{|c|}{ Não Emprego na Região de Ourinhos - Cenário Tradicional } \\
\hline Atores Tradicionais & \multicolumn{2}{|c|}{ Recursos Tradicionais } \\
\hline SPE de Ourinhos & Terra/Projetos \\
\hline Sindicato dos Ferroviários & Apoio/Recursos \\
\hline Fundo Nakasone & Humanos/Conhecimento \\
\hline Empresa Atlântico Sul (ex-RFFSA) & $\begin{array}{l}\text { Apoio/Recursos } \\
\text { Humanos/Conhecimento }\end{array}$ \\
\hline Prefeitura Municipal Ourinhos & R\$, Interesse, Apoio \\
\hline Dersa & Apoio, Terra, Planejamento, R\$ \\
\hline ADTP & Projeto/Apoio Institucional \\
\hline
\end{tabular}

Fonte: Fontes (1997). 


\begin{tabular}{|l|l|}
\hline \multicolumn{2}{|c|}{ Quadro 8 } \\
\hline \multicolumn{2}{|c|}{ Não Emprego na Região de Ourinhos - Cenário Inovador } \\
\hline Atores Inovadores & Recursos Inovadores \\
\hline Prefeitura Municipal de Ourinhos & R\$, Institucional Político \\
\hline Associação Comercial de Ourinhos & Divulgação/ Apoio \\
\hline Secretaria Municipal de Educação & Coordenação/Desenvolvimento \\
da Criança
\end{tabular}

Fonte: Fontes (1997).

\subsubsection{Pontos Fracos e Pontos Fortes de Ourinhos}

O próximo passo da Oficina foi executado com os participantes definindo as operações necessárias para o encaminhar resoluções dos problemas priorizados por cada um dos grupos, apontando os caminhos que deveriam ser percorridos quando da situação real na comunidade.

No segundo módulo da Oficina desenvolvida pelo IBAM, os participantes seriam levados a perceber o "fio lógico" do método aplicado no trabalho e suas possibilidades de uso na comunidade de Ourinhos. 
II. Desenvolvimento Econômico Local

Os enfoques foram o planejamento municipal tradicional e o planejamento estratégico e a importância de se obter o perfil econômico do Município para que este perfil possa servir de instrumento para a comunidade enfrentar os desafios do processo de desenvolvimento no novo cenário macroeconômico, dada a necessidade de se ter informações confiáveis para o processo de tomada de decisão de investimentos e ações, tanto no setor público quanto no privado.

Com este objetivo, aos participantes, agora organizados em dois grupos foi proposto que respondessem algumas perguntas chaves, procurando analisar aspectos relacionados com a infra-estrutura e serviços, com a demografia e com o tecido econômico local.

O resultado do levantamento permitiu a identificação de pontos fortes e fracos do Município:

\section{Pontos Fracos}

- Proximidade com outros centros mais potencializados

- Predominância da monocultura

- Possibilidade de queda da arrecadação

- Enfraquecimento do comércio local

- Prolongamento da Castelo Branco

- Baixo nível de escolaridade

- Poucos cursos de formação de mão-de-obra

- Mão-de-obra não especializada

- Poucos cursos de formação tecnológica

- Falta de curso superior

- Dificuldade de obtenção de recursos e formatação de projetos

- Falta de "Identidade"

- Falta de marketing da cidade

- Marketing da qualidade do serviço fraco 
- Falta de lazer

- Questões ambientais

- Falta de representação política

- Ausência de políticos mais influentes

- Distanciamento Político do poder central

- Falta de conhecimento das oportunidades

- Pessimismo dos investidores

- Distância da capital

\section{Pontos Fortes}

- Posição geográfica (proximidade c/ Paraná)

- Pólo demográfico excelente

- Posição geográfica estratégica

- Localização geográfica boa

- Localização geográfica e malha viária favorável

- Prestação de serviços especializados

- Área urbana relativamente estruturada

- Infra-estrutura básica

- Infra-estrutura adequada

- Infra-estruturas econômicas e sociais adequadas

- Os problemas são de fácil solução

- Vontade política do "novo" setor público em buscar investimentos

- Setor de transporte preparado e pronto para a expansão

- Navegabilidade do rio Paranapanema

- Entroncamento rodo-ferroviário

- Mais cursos superiores 
- Setor de educação tecnológica em expansão

- Fartura de recursos naturais

\subsubsection{Marketing Público de Ourinhos}

A última tarefa, ligada ao quarto módulo ${ }^{7}$, passada aos participantes foi que discutissem qual a imagem com que Ourinhos poderia se ver fortalecida e que slogan cada grupo proporia para refletir essa imagem. Para isto, os grupos fizeram uso de toda a discussão realizada até o momento na Oficina, e concluíram que as idéias para o desenvolvimento econômico local de Ourinhos estariam bem situadas através do seguinte slogan:

\section{OURINHOS - O PORTAL DO MERCOSUL}

O relatório da Oficina chama atenção para o fato de que "os dois grupos chegaram ao mesmo slogan sem que tivesse havido comunicação entre eles, mostrando que o fato relacionado com a localização geográfica de Ourinhos mobiliza fortemente seus habitantes, que compreendem sua imagem colada às rodovias, ferrovias e hidrovias que a cercam".

O IBAM julgou necessário que a comunidade local encontrasse meios de Ourinhos não ser apenas passagem de mercadorias e viajantes, mas dinamizar a economia local a partir das condições dadas pelas suas características endógenas além de explorar as possibilidades existentes decorrentes de sua vantagem locacional.

A conclusão foi que seria muito importante realizar um trabalho de reconhecimento do Município e suas potencialidades, com base nas possibilidades de desdobramentos dos resultados obtidos na Oficina, apontando como desejável a realização de um Plano Estratégico que contemple em seu processo a participação de todos atores sociais e econômicos da comunidade.

Sugeriu ainda o Instituto, o acompanhamento dessa ação por um trabalho de marketing municipal consistente, que deveria dar condições de visibilidade às vantagens de Ourinhos como um local atraente para novos empreendimentos e investimentos externos.

\subsubsection{Criação da Agência de Desenvolvimento Econômico de}

\section{Ourinhos}


Após a Oficina de Desenvolvimento Econômico Local, as lideranças empresariais, políticas e educacionais de Ourinhos dedicaram-se a encontrar uma forma de institucionalizar o planejamento estratégico de Ourinhos, conforme havia recomendado o IBAM.

Embora a idéia da criação de uma agência de desenvolvimento já viesse se esboçando desde outubro de 1996, como uma maneira de organizar a comunidade local em uma instituição que levasse adiante as iniciativas locais de desenvolvimento $^{8}$ de Ourinhos de forma independente, com a mínima interferência indispensável do setor público local, a expectativa de apoio e orientação da Secretaria da Ciência, Tecnologia e Desenvolvimento Econômico foi fundamental para definir as ações para consolidar este plano.

A criação de uma agência de desenvolvimento econômico local que vinha sendo formatada de acordo com as recomendações da Secretaria da Ciência, Tecnologia e Desenvolvimento Econômico de São Paulo, antes mesmo de serem expostas no lançamento do plano "Estratégia Competitiva do Estado" no Congresso de Novos Prefeitos e Vereadores, no início de 1997, foi decidida então e iniciou-se as articulações necessárias para criar uma ADL em Ourinhos: a Agência de Desenvolvimento Econômico de Ourinhos - ADEO -, com apoio político do prefeito eleito, Toshio Misato, e do secretário da Ciência, Tecnologia e do Desenvolvimento Econômico do Estado de São Paulo, Emerson Kapaz.

As expectativas da comunidade eram grandes com a nova instituição e na assembléia de constituição da agência, em 07 de julho de 1997, presenciada pela maioria dos empresários, comerciantes e industriais de Ourinhos, além de alguns políticos, na maior parte ligados ao prefeito eleito, foi aprovado seu estatuto social.

As lideranças locais se manifestaram com otimismo com relação à nova organização não-governamental da cidade:

“A criação da ADEO tem tudo para mudar a história do nosso desenvolvimento, inaugurando um novo modelo na região e aglutinando, para cá, pelo seu pioneirismo, as atenções das lideranças empresariais e políticas de todo o Estado de São Paulo", avaliava o prefeito Toshio Misato. 
II. Desenvolvimento Econômico Local

O secretário de Desenvolvimento Econômico de Ourinhos, Eglair Vascão, lembraria outra vantagem: “Com a ADEO o governo municipal dará a suas ações objetivos estratégicos, definidos a partir de uma parceria concreta com a sociedade civil, o que aumenta sua credibilidade".

O coordenador acadêmico da Faculdade de Tecnologia - FATEC - de Ourinhos, professor Paulo Chíxaro concluía que "a instalação de uma ADL é importante para facilitar o desenvolvimento integrado sob o enfoque de multiáreas, uma necessidade que se impõe a qualquer município que queira levar a sério seu desenvolvimento".

Já a presidente da Associação Comercial e Industrial, Lavínia Gomes de Oliveira, acreditava que a "a ADEO é um instrumento pelo qual se abrem horizontes para o processo de globalização, aumentando as oportunidades de negócios - no município e na região".

O empresário Ricardo X. Simões, o grande incentivador da criação da agência de Ourinhos, era o maior entusiasta da nova instituição. Eleito presidente da diretoria da ADEO, Simões dizia que um de seus principais objetivos era não perder o "bonde da história".

Segundo ele: "Nos próximos dez anos, o Brasil deverá passar por um grande desenvolvimento e as cidades devem estar preparadas para acompanhar este salto de qualidade".

Simões defendia, ainda, o investimento em educação para se alcançar o desenvolvimento, pois, segundo ele, a competitividade no mercado de trabalho exigiria cada vez mais do trabalhador. "É preciso levar a cultura e a informação para a população, porque daqui para a frente quem não tiver conhecimento não tem emprego", analisava ele.

Para o eleito presidente da ADEO, tudo seria uma questão de engenharia de desenvolvimento e, garantia ele, contratar, a preço de custo, um plano macroeconômico para a região de Ourinhos, seria possível através de uma parceria da ADEO com a Agência de Desenvolvimento Tietê-Paraná - ADTP.

Com este plano, pretendia Simões, entre outros objetivos macro estratégicos para o desenvolvimento econômico local, viabilizar a construção de 
II. Desenvolvimento Econômico Local

um terminal intermodal de cargas e retomar a construção de uma usina hidroelétrica do rio Paranapanema, cujas obras estão paralisadas a vários anos.

\subsubsection{Missão da ADEO no Desenvolvimento de Ourinhos}

As lideranças de Ourinhos ainda apontaram ${ }^{9}$ questões relevantes que justificariam uma atuação da ADEO:

- Crescem as oportunidades para as cidades interioranas pela saturação das metrópoles, que devem se promover;

- Não basta o setor público oferecer terrenos e facilidades fiscais, há necessidade de qualificar a mão-de-obra, oferecer qualidade de vida e infra-estrutura, além de se diferenciar pela logística;

- É necessário adquirir um conhecimento profundo da realidade do município e de suas reais potencialidades;

- É fundamental criar mecanismos para disseminar as informações do município de Ourinhos;

- É importante a gestão junto a órgãos governamentais e privados para potencializar a ampliação de escolas de ensino tecnológico na região;

- Ourinhos cresce acima da média do estado de São Paulo e é preciso buscar novas oportunidades de emprego e renda para sua população.

Para atender as expectativas locais, a ADEO nascia com uma ambiciosa missão: "promover o desenvolvimento econômico da região de Ourinhos, procurando, para tanto, harmonizar o crescimento econômico com a exploração racional de seus recursos econômicos, físicos, humanos e naturais, visando a melhoria da qualidade de vida da população, crescimento da oportunidades de negócios, aumento de renda "per capita" e pleno emprego", registrada em seu estatuto social.

\subsubsection{Ações Estratégicas da ADEO}

Conforme estabelecido em seus estatutos, visando atender seus objetivos, a ADEO deveria obedecer "a um plano de desenvolvimento econômico 
II. Desenvolvimento Econômico Local

local o qual deverá determinar ações estratégicas para se alcançar o fortalecimento das atividades econômicas regionais, bem como estimular o estabelecimento de novos investimentos estaduais, nacionais e internacionais na região de Ourinhos".

Assim, a nova instituição estaria fundamentando um adequado planejamento estratégico para seu funcionamento, baseando sua atuação nas seguintes atividades previstas em seu estatuto social:

“I - apoio às empresas já instaladas na região de Ourinhos, auxiliandoas nas resoluções de problemas específicos ou comuns, sejam de natureza administrativa, econômico-financeira, tecnológica, ambiental, políticoinstitucional ou infra-estrutural;

II - assistência aos empresários interessados em investir nesta região, em questões como locação de projetos, obtenção de recursos, facilidades energéticas, de comunicação e de transportes, ambientais e tecnológicas;

III - assistência na criação de empresas de participação comunitária, incentivando o desenvolvimento de uma cultura empreendedora na comunidade local;

IV - fomento à consolidação de infra-estrutura empresarial competitiva para a região, participando, em parceria com outras instituições, da instalação de incubadoras e condomínios para as atividades industriais, de serviços, comerciais e agro-industriais;

V - análise de viabilidade da região para a formatação de um pólo ou parque tecnológico promovendo o intercâmbio dos agentes necessários para sua estruturação;

VI - elaboração de programas para a qualificação dos recursos humanos;

VII - elaboração de projetos de infra-estrutura, especialmente na área de transportes aero-hidro-rodo-ferroviário, visando não apenas o escoamento da produção local, como também a adequada circulação de mercadorias de outras regiões do país e do continente que passam por Ourinhos e região;

VIII - promoção nos níveis regional, estadual, nacional e internacional das oportunidades de negócios na região de Ourinhos, valendo-se de recursos da 
II. Desenvolvimento Econômico Local

mídia tradicional e dos novos meios de comunicação eletrônicos, sistematizando-a através de um banco de dados municipal integrado às agências de informações de secretaria estaduais, organizações e outras instituições nacionais e internacionais de fomento ao desenvolvimento econômico, tendo por objetivo o atendimento da demanda da sociedade por informações, em particular das iniciativas locais e empresariais, visando agilizar processos de decisões, tanto no âmbito público quanto no privado;

IX - elaboração, execução, implantação e revisão de planos de desenvolvimento econômico municipais e regionais a serem propostos para a região de Ourinhos".

\subsubsection{Implantação da ADEO}

A premissa para o funcionamento da agência de Ourinhos seria a obtenção de recursos para suas atividades básicas, com os quais a ADEO teria condições para estruturar as ações previstas em seu estatuto social.

A oportunidade para iniciar seu funcionamento básico surgiu com a ativação de um protocolo de intenções firmado em agosto de 1996 entre a Prefeitura Municipal de Ourinhos, a Universidade Estadual de Campinas UNICAMP -, a Universidade Estadual Paulista - UNESP - e o Serviço de Apoio às Micro e Pequenas Empresas de São Paulo - SEBRAE/SP -, visando a promoção de micro e pequenas empresas de São Paulo.

Como estava previsto em seu estatuto, a ADEO poderia se encarregar de:

"IV - fomento à consolidação de infra-estrutura empresarial competitiva para a região, participando, em parceria com outras instituições, da instalação de incubadoras e condomínios para as atividades industriais, de serviços, comerciais e agro-industriais".

E, dessa maneira, estaria capacitada a estabelecer um convênio com o SEBRAE/SP com o propósito conjunto de promoverem a Implantação e Operacionalização da Incubadora Empresarial de Ourinhos. 
II. Desenvolvimento Econômico Local

Seria de responsabilidade de ADEO viabilizar o espaço físico para a incubadora, e obter recursos complementares aos previstos no convênio a serem repassados pelo SEBRAE/SP para desenvolver o projeto.

Com apoio financeiro da Prefeitura Municipal, foi locada uma indústria desativada no Distrito Industrial de Ourinhos, que remodelada e adaptada passou a receber micros e pequenas empresas, atuando como gestora da ocupação da incubadora.

Esta foi a maneira encontrada: os recursos do convênio possibilitaram contratar staff administrativo que ao mesmo atendia as empresas em processo de incubação e viabilizava a operação da agência, permitindo a elaboração de um plano de ações para sua implantação.

\subsubsection{Planejamento Estratégico do Desenvolvimento Local de}

\section{Ourinhos}

A atuação da Agência de Desenvolvimento Econômico de Ourinhos, como uma entidade sem fins lucrativos criada sob o amparo do governo municipal com apoio de empresários locais deveria buscar um sintonia com o plano "Estratégia Competitiva" desenvolvido pela Secretaria Estadual da Ciência, Tecnologia e Desenvolvimento Econômico, pois acreditava-se que seria uma maneira de obter recursos para a operacionalização de suas ações.

A ADEO como uma organização não-governamental, embora contasse em sua estrutura deliberativa com representante indicado pela Prefeitura Municipal, deveria ter sua atuação essencialmente apolítica, buscando, principalmente, na comunidade econômica da cidade respaldo para sua atuações, mas esta tarefa mostrava-se de difícil concretização.

Creditava-se a iniciativa como uma decisão política do prefeito eleito e portanto a administração municipal deveria buscar por conta própria os recursos necessários para implantar as ações estratégicas necessárias, embora todos concordassem com a premência de algumas delas para reativar a economia local.

De qualquer maneira, houve uma estruturação para a consecução do que seria um plano de ações estratégicas, com descrição das táticas desenvolvidas para cada uma delas e o material de apoio necessário. 
Deste plano constavam as seguintes ações estratégicas:

\section{Apoio às empresas existentes no município}

O objetivo era buscar a melhoria da competitividade e expansão das empresas locais evitando o fechamento de postos de serviços, possibilitando, ainda, a criação de mais empregos na região

Basicamente a tática empregada foi uma programação de visitas às empresas locais em uma atitude proativa, com intenção de se antecipar às necessidades dos empresários de Ourinhos de maneira que fossem evitadas situações críticas como encerramento das atividades produtivas na região.

O trabalho teve no início um bom apoio da administração municipal, com o secretário de desenvolvimento econômico atuando junto com o prefeito. Dessa maneira, foram realizadas algumas visitas que visavam formalizar os compromissos da Prefeitura Municipal com a comunidade empresarial local, através da atuação da ADEO neste segmento da comunidade local.

$\mathrm{Na}$ ocasião foi providenciado o encaminhamento de questões relativas ao empresariado, constando de um questionário específico com questões estratégicas das empresas.

Às empresas foi solicitado que fizessem uma avaliação das vantagens regionais e de suas gestões empresariais. Alguns questionários foram entregues às grandes empresas do distrito industrial, mas apenas uma das empresas contatadas forneceu respostas.

Para dar prosseguimento, a diretoria executiva da ADEO deveria participar do processo apoiando as visitas e reforçando a importância de se obter um participação integral dos empresários para apoio a um plano de ações que permitiria aumentar a competitividade das empresas no nível nacional e internacional, superando obstáculos e dificuldades tanto particulares quanto comuns.

Nesta abordagem junto aos empresários do município, um plano de marketing se faz necessário para a consolidação dos propósitos da ADEO e deveria ter apoio de assessoria de imprensa da Prefeitura Municipal de Ourinhos para envio de clipping do material já publicado na imprensa local e estadual. 
II. Desenvolvimento Econômico Local

Pretendia-se com este instrumento uma análise interna do perfil das empresas regionais para suporte de planejamento estratégico local e apoio às atividades da ADEO. Esperava-se também, com isto, um marketing institucional para adesão de associados de porte da região.

O público alvo desta ação seria os empresários locais e os produtos necessários para implementar esta ação eram: conjunto de questionários acompanhado de ofício assinado pelo prefeito, material de divulgação da ADEO como clipping de imprensa e cópia do estatuto social. Foi sugerido um reforço com telemarketing através de ação conjunta com a Associação Comercial e Prefeitura.

\section{Atração de potenciais investidores}

O objetivo desta ação seria aumentar as atividades econômicas na região com criação de novos de postos de serviços e de novas empresas que deveriam colaborar com os processos produtivos através de novos empreendimentos.

A tática a ser adotada contaria com a participação da ADEO em eventos como feiras, fóruns, seminários e simpósios sobre transportes e privatizações de serviços públicos, sendo que com isto se visava ser a ADEO caracterizada como uma agência com portfólio de oportunidades de negócios.

Deveriam ser programadas visitas aos bancos de desenvolvimentos e agências financiadoras de projetos, tanto no nível nacional quanto internacional. Câmaras de comércio, federações das indústrias e outras entidades patronais, seriam vistas como potenciais facilitadores de contatos de alto nível.

O secretário do desenvolvimento econômico atuou junto com o prefeito realizando algumas visitas e programando audiências. Porém, seria importante que a diretoria técnica da ADEO estivesse participando e apoiando as visitas com explanações sobre o resultado de análises interna e externa com relação ao planejamento estratégico de Ourinhos, o que não aconteceu.

Foi sugerida a formulação de um plano de ações que permitisse aumentar a competitividade local e requalificar a mão-de-obra da região para atrair, por meio destas vantagens comparativas, empresas de nível nacional e internacional. 
II. Desenvolvimento Econômico Local

Nesta ação, o público alvo seria: empresários, bancos de desenvolvimento, agências internacionais de desenvolvimento, câmaras de comércio, federações de indústrias.

Para atingir seus objetivos os produtos necessários seriam: portfólio com planejamento estratégico de Ourinhos, folder e vídeo sobre potencialidade regional, devendo o material estar redigido em português, inglês e espanhol.

\section{Formação de empresas de participação comunitária}

O objetivo desta ação seria incentivar uma cultura empreendedora na comunidade local através de uma Empresa de Participação Comunitária - EPC -, e através dela a criação de empresas filhas que iriam gerar empregos e receita tributária, com aumento do nível de renda da população.

A tática aplicada foi sugerida com divulgação na comunidade local e regional do processo de formação das EPCs. A diretoria executiva da ADEO deveria participar essencialmente através de apoio local para o trabalho do SEBRAE/SP, responsável por este programa, já implantado então em outras cidades paulistas e do sul do Brasil.

Foi sugerido que a diretoria da ADEO visitasse cidades onde o SEBRAE/SP está com EPCs em formação e funcionamento para se evitar erros na implantação da EPC em Ourinhos.

O público alvo da ação seria: profissionais liberais, professores universitários, comerciantes, representantes comerciais, além de alunos do curso de formação de empreendedores em realização na Escola Técnica estadual de Ourinhos.

O material básico necessário seria: folder, publicação em jornal e divulgação em rádio para comunicação local, além de palestras.

\section{Criação de incubadoras e condomínios industriais}

O objetivo destas ações seria oferecer suporte financeiro, administrativo, de comercialização e tecnológico para a criação e viabilização de micro e pequenas empresas na comunidade local, de forma tal que as atividades industriais e comerciais destes tipos de empreendimento industrial e/ou 
tecnológico fossem viáveis, reduzindo ao mínimo a possibilidade de fracasso financeiro deste tipos de empreendimentos.

Para a incubadora, a tática seria a divulgação das vantagens empresariais da incubadora na comunidade local junto a potenciais empreendedores, como, por exemplo, recém-formados da FATEC e da Escola Técnica, entidades de classe como Associações dos Advogados, Engenheiros, Médicos, Dentistas, etc..

Foi sugerido que se deveria destacar no processo de formação da incubadora os nomes das instituições SEBRAE, UNESP e UNICAMP, coresponsáveis por este programa, mostrando as experiências bem-sucedidas de incubadoras já implantadas em outras cidades.

Como parte da tática, a sugestão era que a diretoria técnica da ADEO realizasse visitas às cidades onde incubadoras estão em formação e funcionamento para se evitar erros na implantação em Ourinhos, preparando material para palestras sobre estas visitas.

Também foi colocado que o perfil tecnológico da incubadora seria desejável mas, não deveria limitar as expectativas de sucesso da incubadora. Mas o propósito de qualificação tecnológica de Ourinhos deveria ser estimulado, sendo sugerido criar no local, em prédio independente, uma mini incubadora de alta tecnologia para desenvolvimento de produtos ligados à área de informática e telecomunicações com apoio da FATEC e da Escola Técnica.

Contatos preliminares detectaram que empresas locais industriais já haviam se mostrado interessadas em participar estimulando o surgimento de fornecedores a partir de empresas incubadas, dessa forma se fazia necessário um encontro com representantes destas empresas para determinar que tipo de fornecedor se pode estimular para complementar a base industrial existente.

O público alvo seria: professores universitários, pequenos produtores artesanais, pesquisadores, alunos do curso de formação de empreendedores e industriais informais.

Para implantar a ação seriam necessários os seguintes produtos: folder, publicação em jornal e divulgação em rádio visando comunicação ao público alvo e a comunidade empresarial. 
II. Desenvolvimento Econômico Local

Para os condomínios, a tática recomendada foi buscar junto à CETESB nomes de potenciais indústrias poluentes para o condomínio industrial, dando preferência àquelas pequenas e médias empresas que não estariam suportando custos para se adequarem à legislação ambiental ou para se transferirem de localização em função das exigências ambientais.

Deveriam ser desenvolvidos contatos junto à Secretaria estadual do Meio Ambiente para que ela participasse da análise de viabilidade do projeto de condomínio industrial com controle ambiental, apresentado pela CETESB na ECO-92, realizada no Rio de Janeiro e que teria condições ambientais de implantação em Ourinhos.

O público alvo: empresas com problemas ambientais recorrentes em com dificuldades para o crescimento das atividades e também pequenas e médias empresas poluentes.

Os produtos necessários para iniciar esta ação seriam folder, publicação em jornal e vídeo empresarial.

\section{Formatação de um pólo tecnológico}

Com esta ação estaria o objetivo de uma melhoria do patamar tecnológico das indústrias da região com a transformação dos produtos industriais locais em padrão de qualidade internacional.

A tática sugerida seria a criação de novas empresas que fabricassem ou comercializassem produtos oriundos de pesquisa tecnológicas e também a atração de empresas já existentes para novas tecnologias que surgissem em função da aplicação destas pesquisas.

A diretoria técnica da ADEO orientaria esta ação, buscando subsídios em pólos já implantados em outras cidades paulistas e do Brasil. Sugeriu-se visitas às cidades onde pólos estão em funcionamento seriam muito importantes para se evitar erros na implantação em Ourinhos.

Estrategicamente, tendo em vista a existência em Ourinhos de uma possibilidade de atuação imediata, um esforço na direção da indústria cerâmica local. Foi constatado que este setor já conta com um laboratório, ainda inacabado, para controle da qualidade da produção local. 
II. Desenvolvimento Econômico Local

Foi destacada a importância da participação de alunos da Escola Técnica em pesquisas neste laboratório ou da escola, se houvesse condições para qualificá-la para esta atividade.

Foi recomendada a contratação de consultores internacionais através de associação com cidades européias de reconhecida qualificação para um intercâmbio tecnológico. Considerou-se que viabilizar este tipo de intercâmbio é vital.

Para um melhor posicionamento, foi constatada a existência, ainda, de articulações no nível nacional para maior controle da extração de argila, observando-se a tendência para que as empresas cerâmicas se adeqüem a rígidos controles de produção para não serem fechadas. A ADEO deveria desenvolver um estratégia para ganhar aliados, rompendo as dificuldades para comprometimento com um projeto setorial mais amplo, a partir de uma aproximação entre os ceramistas locais, ampliando-se no nível regional e viabilizando a formatação de um pólo tecnológico que teria a grande motivação de aliviar os industriais regionais desta preocupação com a extração que passa a ser articulada por profissionais e consultores de alto nível.

Outra linha de trabalho deveria ser desenvolvido a partir da FATEC, onde os cursos de informática poderiam evoluir para telecomunicações, um segmento de desenvolvimento tecnológico com alto valor agregado.

Recomendava-se, que, embora estes passos fossem nascentes, deveriam ser estimulados, pois um pólo tecnológico se caracteriza pelas inovações que oferecem não apenas em produtos mas também em processos, estando aí a grande possibilidade de uma interação entre FATEC e o setor ceramista.

Foi identificada a possibilidade de um contato com a Rutgers Univesity de New Jersey, nos EUA, a qual possui conceituado centro de pesquisa em cerâmica e estaria interessada em estabelecer convênio com universidades brasileiras.

O público alvo desta ação seria ceramistas e alunos da Escola Técnica e FATEC. 
II. Desenvolvimento Econômico Local

Para iniciar a ação, os produtos deveriam ser: folder sobre cerâmica de alta qualidade, cursos e palestras sobre o tema em Ourinhos com profissionais de alto nível.

A sugestão para aproximar os ceramistas locais do mercado e tecnologia do segmento foi a realização de um evento em Ourinhos: Feira Mercosul da Cerâmica.

\section{Qualificação da mão-de-obra}

O objetivo desta ação, qualificar e requalificar a mão-de-obra local, seria oferecer uma capacitação da força de trabalho para atrair empresas e estimular novos empreendimentos, além de atender as necessidades de mercado atual.

A tática sugerida foi oferecer cursos para a comunidade local em parcerias da ADEO com os sistemas SEBRAE, SENAI, SESI, SESC, além de estabelecer convênios com as faculdades locais FATEC e FIO e também com as Escolas Técnicas da região.

O público alvo desta ação é amplo, constituindo-se de toda a comunidade economicamente ativa de Ourinhos e região.

Os produtos sugeridos foram folders (cursos), chamadas em rádio, faixas, folhetos e assessoria de imprensa.

\section{Promoção de oportunidade de negócios}

O objetivo desta ação estratégica seria otimizar o aproveitamento dos potenciais logísticos e econômicos locais e regionais.

A tática seria identificar e divulgar nichos de mercado ainda não explorados na região de Ourinhos.

Seria público alvo desta ação: empresários internacionais nacionais, regionais e locais, fundos de investimento e bancos.

Os produtos necessários seria: folder (revista), vídeo, CD-ROM, disquetes (com exposição através do software PowerPoint), participação eventos e assessoria de imprensa.

\section{Formação de um banco de dados municipal}


II. Desenvolvimento Econômico Local

O objetivo desta ação seria facilitar análise de investimentos privados e públicos para Ourinhos e região através de um sistema georeferenciado de dados regionais e urbanos.

A tática inicialmente proposta era contratar consultores e empresas especializadas em Geographical Information System - GIS - tendo sido sugerida a implantação de um convênio com a Prefeitura Municipal de Ourinhos e com o CEPAM, órgão do governo estadual de São Paulo, através do qual seria desenvolvido um sistema de dados georeferenciados.

O público alvo desta iniciativa deveria ser local e externo, tais como: investidores privados e públicos, políticos, industriais e secretários municipais e cidadãos comuns.

Os produtos necessários, além do próprio sistema GIS, seriam: folder (manual), Internet (home-page), CD-ROM, disquetes (com apresentação em pelo software PowerPoint), quiosque público e assessoria de imprensa.

\section{Elaboração de projetos de infra-estrutura de transportes}

O objetivo seria facilitar investidores privados e públicos em análise de viabilidade de projetos para a região.

A tática mais adequada seria contratar consultores e empresas especializadas na área, o que seria possível através de um convênio da ADEO com Prefeitura Municipal de Ourinhos, Agência de Desenvolvimento TietêParaná, Escola Politécnica da Universidade de São Paulo e DERSA, órgão do governo estadual de São Paulo.

O público alvo desta ação seria: investidores privados e públicos, políticos, bancos, empresas privatizadas e secretários estaduais.

Os produtos necessários para a ação seriam: folder (projetos), vídeo, CD-ROM, disquetes com apresentação em PowerPoint, assessoria de imprensa e publicação em revistas técnicas.

10. Elaboração de um plano estratégico de desenvolvimento econômico municipal 
II. Desenvolvimento Econômico Local

O objetivo desta ação seria direcionar os esforços políticos e privados para o desenvolvimento econômico local e otimizar o desempenho e competitividade de Ourinhos e região através de suas vantagens específicas.

A tática a ser aplicada seria formar grupos temáticos para discussão em um fórum do desenvolvimento econômico local, onde se ouviria a comunidade em todos seus segmentos, representada, principalmente, por comitês já constituídos. A discussão deveria ser encaminhada, visando se obter um plano estratégico compartilhado pela sociedade e desenvolvido de acordo com a metodologia do plano "Estratégia Competitiva do Estado", que seria realizado em convênio com a Prefeitura Municipal de Ourinhos, Secretaria da Ciência, Tecnologia e do Desenvolvimento Econômico do Estado de São Paulo e do Instituto de Pesquisas Tecnológicas.

O público alvo, em um primeiro momento, seria a comunidade por inteiro, em especial as lideranças políticas, empresariais, educacionais e do orçamento participativo de Ourinhos, depois, com o plano estratégico de desenvolvimento econômico municipal pronto, lideranças políticas e empresariais no nível nacional e internacional.

Os produtos necessários seriam: para a primeira fase, pastas (manual), questionários, crachás, anúncio em jornal, chamadas em rádio, chamadas em TV, imprensa, folhetos e faixas de rua; para a segunda fase o próprio plano estratégico de desenvolvimento econômico municipal, devidamente editado em forma de publicação.

\subsubsection{Parcerias da ADEO}

Desde o início de suas atividades a ADEO buscou parcerias qualificadas para realizar o que seria seu planejamento estratégico, conforme exposto no item anterior, pois seria vital parcerias que pudessem alavancar recursos para o desenvolvimento de suas ações estratégicas.

Seriam, então, parceiros estratégicos da ADEO: Agência de Desenvolvimento Tietê-Paraná - ADTP -, Faculdade de Tecnologia de São Paulo - FATEC -, Centro Estadual de Educação Tecnológica de São Paulo - CEETESP -, Serviços Brasileiro de Apoio às Pequenas Empresas de São Paulo SEBRAE/SP -, Instituto de Pesquisas Tecnológicas - IPT -, Secretaria de 
Ciência, Tecnologia e Desenvolvimento Econômico do Estado de São Paulo SCTDE/SP - e a Universidade de Alberta, do Canadá.

Através destas parcerias, a ADEO procurou firmar convênios para obtenção de recursos humanos e financeiros necessários para a consecução de sua missão, pois a agência de Ourinhos não dispunha de fundos próprios ou de subvenção municipal para seus trabalhos.

\subsubsection{Resultados das Ações da ADEO}

\section{Apoio às empresas existentes no município}

Um questionário formulado pela diretoria técnica ${ }^{10}$ pela ADEO, envolvendo questões estratégicas empresariais foi encaminhado às dez maiores empresas de Ourinhos, tendo sido respondidos três.

Estes, após análise da agência, foram encaminhados à Secretaria Municipal de Desenvolvimento Econômico para apreciação pelo Prefeito.

\section{Atração de potenciais investidores}

Editados pela Secretaria Municipal de Desenvolvimento Econômico uma revista e folder sobre as potencialidades de Ourinhos, o material foi redigido em português e inglês.

O slogan "Ourinhos - Portal do Mercosul", extraído na Oficina de Desenvolvimento Local, foi adotado no material promocional da Secretaria.

\section{Formação de empresas de participação comunitária}

Não houve a formação de EPC em Ourinhos, porém a Prefeitura Municipal criou o Banco do Povo para financiar pequenos e micro empreendedores visando tirá-los da informalidade.

\section{Criação de incubadoras e condomínios industriais}

O gerenciamento em seu primeiro ano foi realizado pela FATEC Ourinhos, conforme convênio formalizado com a mantenedora CEETPS - Centro Educacional e Tecnológico "Paula Souza".

Para a escolha das empresas a serem incubadas foram realizadas reuniões de comissão formada por representantes da ADEO, da Prefeitura 
II. Desenvolvimento Econômico Local

Municipal de Ourinhos, do SEBRAE-SP, da FATEC e da UNESP, que são as entidades que constituem o Conselho de Orientação da Incubadora.

Em dezembro de 1998, a ocupação dos módulos com 10 empresas em incubação gerava cerca de 100 novos empregos diretos em Ourinhos.

A qualificação dos incubados para enfrentar o mercado também era uma das preocupações deste projeto da ADEO, para tanto foi realizado o curso Formação de Novos Empreendedores, com metodologia do SEBRAE/SP, sendo os professores da FATEC.

Quando do seu encerramento, em dezembro de 1999, a incubadora contava com apenas três empresas em incubação, e este pequeno número de participantes foi um dos motivos alegados para a Prefeitura deixar de participar do projeto.

\section{Formatação de um pólo tecnológico}

As dificuldades de articulações no nível local, com uma forte tendência das empresas cerâmicas da região serem administradas de uma forma tradicional e fortemente estruturadas familiarmente não permitiu romper as dificuldades para conseguir um comprometimento com um projeto setorial mais amplo, a partir de uma aproximação entre os ceramistas locais.

\section{Qualificação da mão-de-obra}

A ADEO considerou que, além de contar com insuficiente equipe para organização de cursos, as dificuldades para firmar parcerias com os sistemas SEBRAE, SENAI, SESI e SESC para treinamento de mão-de-obra em Ourinhos não compensavam e a diretoria preferiu que estas iniciativas continuassem a ser exclusividades destes sistemas.

\section{Promoção de oportunidade de negócios}

Esta ação estratégica é semelhante à formulada anteriormente (Atração de potenciais investidores), sendo seus resultados considerados no item 2.

\section{Formação de um banco de dados municipal}


II. Desenvolvimento Econômico Local

Os contatos com o CEPAM, órgão do governo estadual de São Paulo, através do qual também poderia ser desenvolvido um sistema de dados georeferenciados não se efetivaram pela escassez de recursos municipais necessários para implantar o sistema em Ourinhos.

Uma segunda tentativa, com o objetivo de propor a organização de um sistema de informação para os bancos de dados municipais já existentes e utilizados pelas diversas secretarias municipais, de forma que o planejamento de investimentos públicos em infra-estrutura física e social do município fosse feito com uma otimização de recursos, foi firmado um convênio com a Universidade de Alberta, do Canadá, a qual tem sido reconhecida pelos órgãos internacionais de fomento ao desenvolvimento como um centro de excelência em sistemas de informação e geoprocessamento.

A ADEO buscou, com a parceria estabelecida com a Universidade de Alberta, um aval para suas ações desenvolvimentistas em projetos de alto nível que estariam sendo formulados em uma base de dados concebida por especialistas renomados, como é o caso do coordenador do GIS de Ourinhos, Professor Dr. Sundeep Sahay desta universidade canadense.

Segue abaixo, traduzido do original em inglês, o documento apresentado pelo professor Sundeep à ADEO em sua proposta de trabalho:

Projeto GIS: Implantação de sistema de geoprocessamento na cidade de Ourinhos.

O objetivo geral do projeto é um estudo de viabilidade para implantação do GIS (Geographical Information System) o qual deverá oferecer suporte tecnológico e apoio com mapas digitalizados às decisões de natureza ambiental, social e econômica visando o desenvolvimento sustentável na cidade de Ourinhos.

O projeto tem os seguintes objetivos especificos:

Avaliar os recursos técnicos, econômicos, organizacionais e humanos para compreender como estes influenciariam a implementação da tecnologia de GIS na cidade de Ourinhos. 
II. Desenvolvimento Econômico Local

Identificar as decisões específicas de cada departamento que possam se beneficiar da tecnologia oferecida pelo GIS.

Propor configurações técnicas e organizacionais a serem estabelecidas no caso de o GIS ser implementado com resultados positivos para o município.

Fornecer uma base sistemática para preparar uma proposta de projeto detalhada que deverá ser apresentada a uma agência de auxílio internacional para que financie a implementação em larga escala do GIS em Ourinhos.

O projeto foi viabilizado graças ao apoio da Prefeitura Municipal de Ourinhos que reembolsou as passagens internacionais para o professor e para os 2 estudantes, além das demais despesas de estadia dos visitantes canadenses, os quais nada cobraram para este estudo e pesquisa solicitados e gerenciados pela ADEO.

O resultado final, entregue em setembro daquele ano, seria o trabalho "Feasibility Study for Implementing GIS Technology to Support Socio-Economic Planning at Ourinhos", obtido em Ourinhos através de pesquisas de campo com a participação de estudantes da Faculdade de Administração da Universidade de Alberta.

O estudo elaborado pela Universidade canadense foi encaminhado pela ADEO à Prefeitura Municipal de Ourinhos para sua implementação.

\section{Elaboração de projetos de infra-estrutura de transportes}

Uma estruturação de parcerias se fez necessária para viabilizar a contratação da ADTP que havia apresentado uma proposta para elaboração de um plano de desenvolvimento nos moldes de um master plan estratégico, metodologia já aplicada com sucesso pela ADTP em outras regiões do Brasil.

Entretanto, dificuldades acabaram por inviabilizar a idéia deste master plan estratégico de infra-estruturas de transporte intermodal, que seria mais bem abrangente do que o PDM.

Para o SEBRAE/SP, pensando em atuar de forma regional, o projeto da ADTP era muito sofisticado para seus propósitos o que, talvez, se justificasse 
II. Desenvolvimento Econômico Local

no caso de Ourinhos, mas para os outros municípios da região seria sofisticado demais.

Para o IPT, que estava de acordo em realizar alguns itens que estavam contidos na proposta da ADTP, a participação dependeria de ter aceita sua proposta que estava em infindáveis trâmites burocráticos na SCTDE para ser encaixada dentro dos recursos reservados ao PRODEM.

Houve uma tentativa de aproximação com a Comissão Municipal de Emprego (CME), através da Secretária do Bem-Estar Social de Ourinhos, porém o excesso de regulamentação para apresentação de projetos e as dificuldades de sua aprovação no nível estadual pelo Conselho Estadual do Emprego, ligada à Secretaria das Relações do Trabalho, por problemas políticos de disputa entre as secretarias estaduais envolvidas acabaram por inviabilizar os recursos necessários.

Foram realizadas consultas junto ao programa ProTem/PG/CNPq, gerido pelo governo federal, através da Escola de Governo da Faculdade de Economia da UNICAMP, mas em respostas por e-mail a posição era de dúvidas em relação à conveniência de se formular a consulta da ADEO junto a Escola de Governo da UNICAMP ou encaminhar o pedido através do IPT.

Desta maneira, não foi obtido resultado concreto nas articulações realizadas com os possíveis parceiros, e as demoradas negociações em nada resultaram.

10. Elaboração de um plano estratégico de desenvolvimento econômico municipal

A ADEO formulou proposta de convênio, onde o IPT realizaria o plano com recursos da SCTDE, de acordo com a metodologia do plano "Estratégia Competitiva do Estado".

De acordo com a proposta do IPT aprovada pelo Conselho Superior da ADEO, o PDM seria consubstanciado em:

- Um diagnóstico com informações sobre a economia local, principais setores, infra-estrutura, emprego, renda e potencialidades. Este documento, além de servir de base para a 
II. Desenvolvimento Econômico Local elaboração de propostas, é fundamental como fonte de informação para investidores e agências internacionais.

- Realização de um Fórum, para discussão do diagnóstico e desenvolvimento de propostas, com participação da comunidade local, dando transparência ao processo e estimulando o comprometimento de atores locais.

- Definição de uma agenda de propostas, apontando atores responsáveis, tanto ao nível local como estadual ou nacional.

- Documento síntese com conclusões e cronograma para o acompanhamento dos desdobramentos do Plano.

As articulações da primeira diretoria da ADEO, levaram a um comprometimento do SEBRAE que participaria do PDM com material de apoio como fichas de pesquisa para coleta de dados e questionários que deveriam abranger todos setores comerciais, industriais, de serviços e agropecuário, obtendo, com a metodologia própria do PRODER - Programa de Emprego e Renda, um plano de ações estratégicas para combate ao desemprego no município de Ourinhos.

Já na segunda diretoria, os parceiros do plano, após longas e infrutíferas gestões, se mostravam desinteressados, por vários motivos, desde a impossibilidade de arcar com os custos necessários para desenvolver o projeto até mudança de diretriz política, o que levou a Prefeitura e o IPT a desistirem do PDM.

\subsubsection{Situação Atual da ADEO}

Dois anos e nove meses após sua fundação, hoje em sua segunda diretoria, sob a presidência do empresário ourinhense Mauro Novelli o qual assumiu o posto do empresário Ricardo X. Simões, que passou a se dedicar exclusivamente à sua empresa, a ADEO ainda não conseguiu consolidar seu papel na comunidade local.

A sua credibilidade perante a comunidade seria possível se conseguisse vencer a resistência de segmentos da população que desde a sua fundação a viam como uma concorrente na disputa pelo espaço político e não 
II. Desenvolvimento Econômico Local

apenas como uma entidade comunitária que lutava para ir adiante com seus projetos em Ourinhos e que enfrentava dificuldades pela falta de recursos, financeiros e humano, e de apoio político.

Foi o que aconteceu com a incubadora empresarial, o projeto que dava visibilidade à agência de desenvolvimento local no cenário econômico da cidade, encerrou suas atividades no final de 1999 pelo abandono do seu parceiro principal: a Prefeitura Municipal de Ourinhos, quatro meses após o encerramento do convênio que a ADEO mantinha com o SEBRAE.

Os motivos alegados pelo prefeito em exercício ${ }^{11}$ eram dois: a baixa adesão do micro e pequenos empresários locais e as dificuldades financeiras que enfrentava a Prefeitura Municipal e que não lhe dava condições de bancar sozinha todas as despesas da incubadora, situação desde a saída do SEBRAE/SP no final da segunda etapa do convênio, em agosto de 1999.

Outro projeto, o Plano de Desenvolvimento Municipal - PDM, de forte motivação comunitária e estímulo à participação dos cidadãos locais na gestão do desenvolvimento promovido pela ADEO, também é problemático. Pois o PDM, a ser elaborado em parceria com o Instituto de Pesquisas Tecnológicas IPT de acordo com a metodologia do plano "Estratégia Competitiva do Estado", com recursos da SCTDE/SP através do Programa de Desenvolvimento Econômico Municipal - PRODEM, também tem se mostrado inviável.

As informações dão conta que após demoradas negociações entre os parceiros envolvidos, IPT e SCTDE/SP, a atual gestão da Secretaria do Estado de São Paulo vem se decidindo por cancelar o Programa criado na gestão do secretário anterior, o que interromperia o processo iniciado pela primeira diretoria da ADEO destinado a obter verba para os técnicos do IPT executarem o trabalho em Ourinhos.

Neste momento, portanto, a situação é de total desativação dos projetos ligados diretamente à agência de desenvolvimento local, estando a ADEO limitada a reuniões periódicas quando a atual diretoria se atém a reflexões sobre um possível papel para a agência dentro da estrutura institucional disponível no município de Ourinhos.

\subsubsection{Avaliação do Desempenho da ADEO}


Não se pode afirmar, entretanto, que a atuação da ADEO em Ourinhos tenha sido um fracasso total, pois ao levar à discussão da comunidade, antes mesmo de sua fundação oficial, seus problemas para o desenvolvimento econômico obrigou suas lideranças a refletir sobre o futuro da cidade e formular ações para explorar suas potencialidades para o crescimento

O processo de formatação da $\mathrm{ADEO}$, que teve seu início com a Oficina de Trabalho de Desenvolvimento Econômico, coordenada pelo IBAM e patrocinada pela empresa Delfim Verde, resultou, principalmente, em uma série de iniciativas do governo municipal destacando-se entre elas a criação da Secretaria Municipal de Desenvolvimento Econômico.

O surgimento desta pasta municipal pode ser considerada como uma inovação da administração municipal de Ourinhos e como um fator positivo do seu desenvolvimento comunitário, pois delegando as ações públicas de desenvolvimento de forma a orientar as políticas locais no cenário macroeconômico nacional e internacional, passou a dar sentido estratégico às decisões de investimento tanto do setor público quanto do privado, além de cuidar das articulações necessárias para atingir objetivos coletivos da municipalidade.

O papel otimista desempenhado pela primeira diretoria da ADEO levou a Prefeitura Municipal de Ourinhos, através de sua Secretaria de Desenvolvimento Econômico, a criar novas perspectivas para o desenvolvimento da localidade, reforçando sua atuação proativa e projetando a localidade entre instituições públicas e privadas do estado de São Paulo.

Dessa maneira, o conjunto de ações da agência de desenvolvimento local de Ourinhos criou um ambiente favorável a negócios e empreendimentos no município, envolvendo a região em uma atmosfera progressista, o que Kotler, Haider \& Rein recomendam para estimular a atratividade da cidade para investimentos externos.

A atuação da ADEO, na maioria das vezes de forma indireta, através de aconselhamentos e formulações encaminhadas à administração municipal, resultou em soluções ou minimização de alguns problemas de Ourinhos.

Para a falta de distribuição de água e de tratamento de esgoto a ADEO buscou interessados, no país e no exterior, na privatização destes serviços 
II. Desenvolvimento Econômico Local

municipais e articulou para trazer a Ourinhos uma consultoria de nível internacional para os estudos de viabilidade econômico-financeira, a qual mesmo não conseguindo levar adiante o projeto devido a resistências de ordem política, tendo em vista que o fornecimento de água na cidade é realizado a um custo muito baixo e a população não aceitaria elevação da taxa, mostrou a possibilidade aos dirigentes municipais de alavancar recursos de investidores para melhorar a infraestrutura local visando receber novos empreendimentos.

Em outro importante problema de Ourinhos, a existência de poucos cursos superiores, a atuação da ADEO, em conjunto com a Prefeitura Municipal, foi fundamental para uma bem-sucedida empreitada: a vinda da Universidade Estácio de Sá para Ourinhos, trazendo vários de seus cursos superiores. Os esforços da ADEO já vinham sendo realizados há algum tempo porém tinham sido infrutíferos ao tentar trazer a Universidade de Marília, que acabou desistindo por problemas financeiros. Mas esta outra instituição proveniente do Rio de Janeiro realizou a compra de uma área de $50.000 \mathrm{~m} 2$ e já iniciou as obras para seu campus, prevendo realizar vestibulares ainda para o segundo semestre de 2000 .

Na questão do marketing público de Ourinhos, a promoção da cidade pela ADEO teve um papel fundamental colaborando com seus projetos inovadores $^{12}$ para lhe dar uma imagem positiva e uma visão de uma cidade empreendedora, condição que Kotler, Haider \& Rein consideram essencial para a retomada do crescimento econômico.

Esta posição de comunidade inovadora viria estimular algumas iniciativas para que a população se conscientizasse de novos instrumentos que pudessem permitir sua atuação no processo de desenvolvimento local de Ourinhos.

Destacam-se entre estas ferramentas de participação comunitária: a Orçamento Participativo e o Banco do Povo, ambas aplicadas pela administração municipal nesta gestão, com as quais a agência de desenvolvimento local pode ser integrada, no futuro, para consolidar sua missão e retomar seu papel no crescimento sustentável de Ourinhos, baseada que estaria em instrumentos de participação comunitária que deverão contribuir para o desenvolvimento cívico de seus cidadãos e organizações públicas e privadas. 
II. Desenvolvimento Econômico Local

Um outro mérito relevante da atuação da ADEO em Ourinhos foi contribuir para o aperfeiçoamento do desenvolvimento institucional local, buscando de maneira inédita no cenário regional, o entrelaçamento das iniciativas privadas com a política do governo municipal e estadual.

Neste função de articulação interinstitucional, atribuição essencial de uma agência de desenvolvimento segundo Soares, mesmo esbarrando com as dificuldades inevitáveis onde o papel do empreendedor cívico ainda é de difícil compreensão e visto com desconfiança por lideranças da comunidade, que a ele atribui ambições políticas, a ADEO deu sua contribuição para a construção de parcerias em outras instituições de reconhecida competência técnica como a Agência de Desenvolvimento Tietê-Paraná - ADTP e Instituto de Pesquisas Tecnológicas - IPT, estimulando entre elas uma aproximação e colaboração dentro do objetivo comum do projeto de desenvolvimento estratégico de Ourinhos.

As conquistas alcançadas pela ADEO podem parecer pequenas se comparadas com as possibilidades em um ambiente econômico local potencial como o de Ourinhos. Entretanto, a agência de desenvolvimento local de Ourinhos, com seu papel de uma ferramenta de gestão inovadora do crescimento da comunidade, buscou aprimorar um instrumento com o qual uma localidade brasileira, com potencial empreendedorismo cívico, pode se qualificar e reivindicar um lugar no competitivo mundo globalizado.

E, lembrando as considerações de Putnam, que ao analisar a experiência desenvolvimentista comunitária da Itália moderna, buscou explicações em mil anos de sua história, talvez não seja indispensável esperar os mil anos nos quais estruturas institucionais ${ }^{13}$ vêm se aperfeiçoando, sabendo que para nossas cidades isto seria impossível, pois as terras brasileiras realmente começaram a se urbanizar nos recentes últimos cinqüenta anos, o que é muito pouco, porém não justifica a falta de ousadia das lideranças políticas e empresariais a conduzir suas economias locais e regionais. 


\section{Desenvolvimento Industrial Descentralizado}

1. Introdução, 147

\section{Experiência Italiana, 148}

2.1 Origem do Desenvolvimento Descentralizado na Itália, 148

2.2 Desenvolvimento Industrial na Terza Itália, 157

2.3 A Competência Industrial de Módena, 159

3. Industrialização Descentralizada no Brasil, 165

3.1 Tipologia de Aglomeração Industrial, 167

3.2 Algumas Experiências no Brasil, 169

4. Os Pólos Tecnológicos, 184

4.1 Conceito, 184

4.2 Histórico, 185

4.3 O Modelo de Sophia Antipolis, 186

4.4 Experiência Brasileira, 192

5. As Tecnópolises, 202

5.1 Projetos de Tecnópolis no Mundo, 203

5.2 Programa de Tecnópolis no Japão, 206

6. Desenvolvimento Industrial em Londrina, 239

6.1 Histórico do Desenvolvimento Local, 239

6.2 Desenvolvimento Industrial, 244

6.3 A Comunidade Empreendedora, 247

6.4 Plano de Desenvolvimento Industrial de Londrina, 249

6.5 Projeto Londrina Tecnópolis, 266

6.6 O PDI e o Projeto Londrina Tecnópolis, 274 


\section{Introdução}

A ocorrência de processos de desenvolvimento industrial descentralizado em diversas regiões da Europa e o êxito alcançado nestas regiões em termos de competitividade internacional, geração de empregos e crescimento da renda, despertou interesse de governos e pesquisadores em outros países para a aplicação destes modelos de industrialização localizada, como o Brasil.

Porém, ao lado da necessidade de uma indispensável política nacional de descentralização, surgiu um paradoxo em função da interferência dos governos centrais em ações eminentemente regionais e endógenas, caracterizadas como do âmbito exclusivo da política local .

“O paradoxo criado pela descentralização é que esta demanda maior atuação do governo central e uma maior sofisticação dos instrumentos de política ao nível nacional para servir como guia do processo de descentralização, ao mesmo tempo que se torna necessário romper a dependência do governo central"1.

Mas, embora seja premente uma discussão para reformulação de políticas públicas voltadas para a aplicação de novos conceitos de desenvolvimento, reformulando a imprescindível relação entre política local e nacional, há necessidade de considerar alguns pontos relevantes a partir das experiências já documentadas e amplamente discutidas, destacando-se, entre elas, as efetivadas no território italiano pela sua diversidade e originalidade, que se pode constatar a seguir. 


\section{Experiência Italiana}

\subsection{Origem do Desenvolvimento Descentralizado na Itália}

Putnam (1993), ao estudar o peculiar desenvolvimento italiano, observou no impulso industrial a relevância do contexto social, econômico, político e cultural para o sucesso das iniciativas colocadas em prática, com base constitucional, na descentralização com o estabelecimento de governos regionais pelo governo federal da Itália.

Ele percebeu, em levantamentos para aferir o desenvolvimento institucional, concentrando-se na continuidade e mudanças de políticas regionais, que as diferenças de desempenho dos governos locais tinham ligações profundas com a história de cada região a qual explicava aspectos fundamentais da democracia, do desenvolvimento econômico e da vida cívica.

O pesquisador, para ilustrar suas observações, descreve a lúgubre ante-sala do governo regional da Puglia, um afastado e modesto prédio encostado no pátio da ferrovia com seus indolentes funcionários que dedicam ao serviço público regional algumas poucas horas escondidos atrás de fileiras de escrivaninhas, onde um e outro insistente prefeito da região aguarda atendimento sem atenção dos funcionários acostumados a obedecer ordens que vêm de indicações de seus superiores. Estes, enquanto isso, envolvem-se em brigas partidárias para obter nomeações e cargos, fazendo promessas retóricas e demagógicas, difíceis de serem alcançadas, o que desmotiva a população da região em participar das iniciativas governamentais.

"O contraste com a eficiência do governo da Emilia-Romagna em Bolonha é marcante. Visitar o prédio da sede regional é como entrar numa moderna firma high-tech. Uma recepcionista diligente e cortês encaminha os visitantes à sala apropriada, onde certamente o funcionário encarregado chamará no computador os dados referentes a problemas e políticas regionais. A piazza central de Bologna é famosa por seus debates noturnos, em que se revezam constantemente diversos grupos de cidadãos e militantes políticos, e essa discussão apaixonada das questões que estão na ordem do dia vai ecoar nas salas do conselho regional. Pioneiro legislativo em muitas áreas, o governo da Emilia 
III. Desenvolvimento Industrial Descentralizado

passou das palavras à ação, e sua eficácia é atestada por dezenas de creches e parques industriais, teatros e centros de formação profissional espalhados pela região. Os cidadãos que debatem na piazza de Bolonha não deixam de criticar seu governo regional, mas estão muitíssimo mais satisfeitos do que os apúlios. Por que a nova instituição promovida pelo governo federal italiano teve bom desempenho na Emilia-Romagna e na Puglia não?”, pergunta-se Putnam.

Ele identificou estas diferenças no desempenho das, então, emergentes instituições regionais, criadas pelo governo central italiano para representar os diversos meios econômicos, sociais, culturais e políticos da Itália, a partir de um estudo comparativo da dinâmica e da ecologia do desenvolvimento institucional.

Assim, da mesa forma que um botânico estuda de forma comparativa o desenvolvimento das plantas medindo o crescimento de sementes idênticas geneticamente em terrenos diferentes, Putnam examinou a evolução dessas novas instituições, formalmente idênticas, nos diversos ambientes sociais, econômicos, culturais e políticos, que caracterizavam as regiões de cada uma delas. Seu objetivo: descobrir como as instituições representativas podem obter melhor desempenho e funcionar de modo eficaz.

O pesquisador, com isto, pretendia contribuir com evidências empíricas do que ele e demais pesquisadores de ciência política chama de "novo institucionalismo" e esclarecer dois pontos fundamentais desta teoria:

1. As instituições moldam a política, atingindo o comportamento da população, através de mudanças na identidade, no poder e na estratégia de seus atores.

2. As instituições são moldadas pela história, corporificando trajetórias históricas e momentos decisivos, prosseguindo seu caminho sob o que ocorreu antes e isto irá determinar o que vai ocorrer depois. A escolha dos indivíduos é condicionada a circunstâncias que eles não criaram, mas influenciam as condições de escolha de seus sucessores.

Putnam desenvolve o conceito de "desempenho institucional" baseando-se em um modelo simples de governança: demandas sociais ---> interação política ---> governo ---> opção de política ---> implementação; 


\section{Desenvolvimento Industrial Descentralizado}

Portanto, neste modelo, as instituições governamentais recebem subsídios do meio social e geram reações a este meio.

Embora isto pareça simples é um campo cheio de complexidades, pois para ser eficaz, o governo muitas vezes tem que ser previdente e antecipar-se às demandas que ainda não foram articuladas. O que acontece é há uma grande chance de se criar polêmicas e impasses a obstruir o processo.

Mas o desempenho institucional é vital para a vida das pessoas e determina a qualidade de vida da população sobre a qual a instituição operacionaliza suas ações e tem sido foco de discussão dos estudiosos da ciência política aplicada.

Alguns dos pesquisadores desta área, segundo Putnam, pertencem a uma primeira corrente cujo pensamento está voltado para o projeto institucional se dedicando a aspectos formais e jurídicos relacionados ao desempenho democrático, relacionando-o, muitas vezes, à concepção estrutural e processual.

Uma segunda corrente do desempenho das instituições enfatiza os fatores sócio-econômicos como os mais relevantes para a perspectiva democrática dependente que esta é do desenvolvimento social e do bem-estar econômico. Neste pensamento, destacam-se aspectos fundamentais da modernização, como saúde, educação, etc., para uma instituição democrática estável e eficaz, e se acredita que a melhoria do desempenho institucional é parte essencial do processo de modernização.

Os fatores socio-culturais têm sua importância relevada na terceira corrente do pensamento sobre desempenho institucional. Segundo Putnam, pesquisadores, recentemente, explicam as diferenças de governo entre as nações como originárias da cultura cívica dos povos, reforçando a conexão entre os costumes de uma sociedade com suas práticas cívicas.

Esta pesquisa sobre a experiência de desenvolvimento descentralizado na Itália teve como principal objetivo examinar as origens de um governo eficaz, e, abordando um total de 20 regiões da Itália, o pesquisador apresentou uma análise comparativa dos processos e decisões referentes à adoção de políticas em cada uma destas regiões, onde comparações são realizadas sobre as mudanças nas instituições e ações políticas ao longo do tempo e no espaço territorial da Itália. 
III. Desenvolvimento Industrial Descentralizado

Putnam se dedica a analisar a conexão entre a modernidade econômica e o desempenho institucional, destacando a relação entre desempenho e a natureza da vida cívica, que ele chama de "comunidade cívica". Este conceito se caracteriza por uma comunidade onde se encontram "cidadãos imbuídos de espírito cívico, relações políticas igualitárias, por uma estrutura social firmada na confiança e na colaboração".

O pesquisador busca responder à questão essencial: por que certas regiões são mais cívicas do que outras? E, no caso da Itália, objeto de seu trabalho, ele busca a resposta em períodos que remontam cerca de um milênio quando se estabeleceram em diferentes partes deste país dois regimes contrastantes e inovadores: uma poderosa monarquia no sul e um original conjunto de repúblicas comunais no Centro e no Norte. A tradição encarregou-se de sistematizar diferenças regionais com conseqüências decisivas para a qualidade de vida, tanto pública quanto empresarial, hoje existente nas regiões italianas.

Entretanto, para ele esta constatação histórica não é suficiente para explicar o fenômeno do desenvolvimento descentralizado italiano sendo necessário averiguar por que os modelos e sistemas de engajamento cívico influenciam tanto as perspectivas de um governo eficaz e responsável e por que as tradições cívicas vêm se mantendo estáveis por tempos longos.

Putnam busca fundamentar novas conclusões em uma lógica da ação coletiva e no conceito de "capital social" visando não apenas explicar o caso italiano, mas ampliar a capacidade de aplicação de sua análise.

O pesquisador partiu para seus levantamentos para estudar o desempenho institucional, tendo como meta avaliá-lo de maneira criteriosa e convincente, justifica ele seu rigor para obter condições de avaliação em situações perceptíveis facilmente, como o sucesso do novo governo regional na EmiliaRomagna e seu fracasso na Puglia. Para empreender suas análises, ele determinou 12 indicadores do desempenho institucional:

1. Estabilidade do gabinete - o governo regional, assim como o governo nacional italiano, é dirigido por um gabinete que requer apoio da maioria do legislativo, sua instabilidade, refletida em mudanças na composição, afeta a linha política de governo; 
III. Desenvolvimento Industrial Descentralizado

2. Presteza orçamentária - discussões no legislativo podem atrasar a aprovação do orçamento anual no qual estão determinadas as despesas e investimentos do setor público;

3. Serviços estatísticos e de informação - um governo mais bem informado sobre os cidadãos e seus problemas pode servi-lo de modo mais eficaz;

4. Legislação reformadora - produção legislativa em três áreas de atuação: desenvolvimento econômico, planejamento territorial e ambiental e serviços sociais. Três critérios foram utilizados: abrangência, coerência e criatividade dos legisladores para atender as necessidades e os problemas sócio-econômicos de sua região;

5. Inovação legislativa - abordando conteúdo de leis sobre: regulamentação da mineração de superfície, fomento da pesca, controle de poluição do ar e da água, classificação de hotéis, assistência médica preventiva, proteção à fauna, racionalização do comércio, proteção ao consumidor, monitoração do mercado de trabalho, promoção do serviço voluntário, ombudsmen regionais e atendimento psiquiátrico. Inovações nestas leis foram se propagando pelos governos regionais mais atrasados à medida que conselhos progressistas se encarregavam de introduzi-las em suas regiões.

6. Creches - uma bem-sucedida política dos governos regionais, aproveitando recursos vindos do governo central italiano, foi um indicador da capacidade local de administrar o recurso externo;

7. Clínicas familiares - uma medida da capacidade da região para implementar reformas de políticas na área da saúde;

8. Instrumentos de política industrial - o grau de sofisticação alcançado pelas regiões na área da política industrial é aferido pela quantidade de instrumentos que elas efetivamente utilizaram entre seis mais conhecidos: plano regional de desenvolvimento industrial, plano regional de utilização da terra, parques industriais, agências de financiamento do desenvolvimento regional, consórcios de 
III. Desenvolvimento Industrial Descentralizado desenvolvimento e comercialização industriais, e programas de capacitação no emprego;

9. Capacidade de efetuar gastos na agricultura - capacidade da região para implementar políticas aferida através de recursos que lhe foram destinados pelo governo nacional e que realmente utilizou conforme o planejado pelo conselho regional;

10. Gastos com unidade sanitária local - este indicador, baseado nos gastos per capita com saúde, reflete a mais importante incumbência delegada pelo governo central aos governos regionais que foi o suporte financeiro para gerenciar o serviço de saúde nacional, incluindo hospitais, clínicas e seguro-saúde;

11. Habitação e desenvolvimento urbano - os programas de moradia foram altamente prioritários para os governos regionais tendo em vista recursos abundantes que o governo central direcionou às regiões, subvencionando habitações e empreendimentos tanto públicos quanto privados. O indicador levanta a capacidade da região para utilizar os recursos que lhe foram destinados pelo governo nacional e que realmente a região aproveitou para o desenvolvimento urbano e moradias;

12. Sensibilidade da burocracia - avalia a sensibilidade dos governos em face das demandas do cidadão comum, para levantar este indicador a equipe de pesquisa usou de artifícios para obter informações sobre reembolso de despesas médicas, treinamento profissional e empréstimos para agricultura, medindo o tempo que os governos regionais levavam para atender as solicitações.

Esta amplitude de indicadores, observou Putnam, seria suficiente para “dar uma noção da diversidade de coisas que os governos modernos fazem para os cidadãos e pelos cidadãos”.

Entre os focos de seu estudo, destaca-se a abordagem sobre a região da Emilia-Romagna feita pelo pesquisador em todos estes indicadores, comparando seu desempenho institucional com as outras regiões enfocadas na pesquisa $^{1}$ : 


\section{Desenvolvimento Industrial Descentralizado}

"Por outro lado, a Emilia-Romagna, a região mais cívica de todas, está longe de ser uma comunidade no sentido clássico - a aldeia intimista idealizada pela memória popular. Ao contrário, a Emilia-Romagna é uma das sociedades mais modernas, dinâmicas, abastadas e tecnologicamente desenvolvidas da face da terra. E no entanto abriga uma extraordinária concentração de redes de solidariedade social e uma população dotada de um espírito público extraordinariamente desenvolvido - um verdadeiro complexo de comunidades cívicas. A Emilia-Romagna não é habitada por anjos, mas, dentro de suas fronteiras (e também nas regiões vizinhas do Centro-Norte da Itália), todo tipo de ação coletiva, inclusive o governo, é facilitado por normas e sistemas de engajamento cívico, profundamente arraigados nas tradições regionais, mas seria absurdo classificar a Emilia-Romagna como uma sociedade tradicional".

Ainda constatou Putnam, entre outros fatos, que:

Enquanto há 400 crianças por creche na Emilia-Romagna, existem 12.560 crianças por creche na Campânia;

A taxa de mortalidade infantil é de 15 para cada mil nascimentos na Calábria e na Emilia-Romagna 11;

A capacidade das regiões em utilizar os recursos para habitação e desenvolvimento urbano com qualidade das construções, mostra um índice de $67 \%$ para a Emilia-Romagna e de $32 \%$ na Sicilia e Calabria;

Das 12 leis modulares contendo inovação legislativa, apenas uma chegou a ser aprovada na Calábria, enquanto que na Emilia-Romagna todas as 12 foram aprovadas e 5 foram introduzidas;

A legislação reformadora, de pontuação máxima de 15 pontos, na Calábria e Molise tiveram fraco desempenho atingindo 3 pontos, enquanto a Emilia-Romagna teve excelente desempenho nas três abordagens atingindo a pontuação máxima 15 ;

$\mathrm{O}$ índice de comparecimento às urnas nos principais referendos entre 1874 e 1987 foi em média de 89\% na Emilia-Romagna contra 69\% na Calábria; 
III. Desenvolvimento Industrial Descentralizado

Quanto ao voto preferencial $^{2}$ que indica o grau de relações de clientelismo, a região da Emilia-Romagna manteve o percentual de 17\% nas últimas décadas, enquanto que na Calábria e na Campânia atinge 50\% dos votos;

Quanto à sensibilidade da burocracia que nas mais eficientes (EmiliaRomagna e Valle d'Aosta), duas das três solicitações obtiveram respostas completas no prazo de uma semana, a contar do primeiro contato pelo correio, e a terceira exigiu uma única chamada telefônica. Nas menos eficientes (Calábria, Campânia e Sardenha) nenhuma das cartas recebeu resposta, e duas das três solicitações levaram muitas semanas e exigiram várias chamadas telefônicas e uma visita pessoal para serem atendidas;

No indicador de serviços estatísticos e de informação, em último lugar ficaram as seis regiões que não dispunham de nenhum desses serviços: Abruzos, Calábria, Campânia, Marche, Molise, Puglia e Sicília. Em primeiro lugar ficaram cinco regiões: Emilia-Romagna, Friulli-Veneza, Giulia, Lácio, Lombardia e Toscana, com bons serviços de informação, incluindo postos de coletas de dados locais, processamento de estatísticas e análise por computadores.

Comentando os resultados, o pesquisador considera que diferenças entre as regiões italianas, vêm de há muito tempo. Desde 1901 quando a EmiliaRomagna, estava apenas dentro da média nacional em termos de industrialização, com $65 \%$ da força de trabalho no campo e somente $20 \%$ nas fábricas, a Calábria era ligeiramente mais industrializada do que a Emilia-Romagna (com 63\% de sua força de trabalho na agricultura e $26 \%$ na indústria). Mas, na verdade, a economia da Calábria era "paleo-industrial", pois a indústria era primitiva e os cidadãos mais pobres e menos instruídos, enquanto na Emilia-Romagna a agricultura era próspera. Por outro lado, a taxa de mortalidade na Emilia-Romagna na primeira década deste século era pior que a média nacional, enquanto a da Calábria era um pouco melhor que essa média, muito embora, assustadora em termos absoluto. Independente das diferenças sócio-econômicas marginais entre elas, ambas as regiões eram atrasadas.

Já no tocante à participação política e solidariedade, verificou o autor que a Emilia-Romagna tinha na virada do século, e ainda hoje, como há quase um milênio antes, a cultura mais cívica de toda a Itália. Por sua vez a Calábria tinha, e 
III. Desenvolvimento Industrial Descentralizado

ainda tem a menos cívica das culturas regionais italianas - feudal, fragmentada, alienada e isolada.

O que aconteceu, segundo o estudioso, foi que nas oito décadas subseqüentes, criou-se entre as duas regiões um hiato social e econômico de notáveis proporções e, enquanto, entre 1901 e 1977, a parcela da força de trabalho na indústria duplicou na Emilia-Romagna (de 20 para 39\%), diminuiu na Calábria (de 26 para 25\%), devendo-se observar que foi a única região onde isto ocorreu. Outra interessante conclusão foi que, graças ao progressos na medicina e na saúde pública, a mortalidade infantil diminuiu substancialmente em toda a Itália, mas a Calábria permaneceu bem atrás da Emilia-Romagna.

Além disso, nos anos 80, verificou Putnam, que a Emilia-Romagna, com uma das mais dinâmicas economias do mundo, estava em vias de se tornar a mais rica região italiana e uma das mais adiantadas da Europa, ao passo que a Calábria era a região mais pobre da Itália e uma das mais atrasadas da Europa. De 1970 a 1988, entre as 80 regiões da Comunidade Européia classificadas pelo PIB per capita, a Emilia-Romagna pulou do $45^{\circ}$ para $17^{\circ}$ lugar, o maior salto jamais registrado por uma região da Europa, enquanto a Calábria continuou estacionada no último lugar durante todo o período.

O pesquisador considera que tais correlações, sugerem uma hipótese curiosa: talvez as tradições regionais de participação cívica no último século ajudem a explicar as atuais diferenças no nível de desenvolvimento. Em outras palavras, talvez o civismo ajude a explicar a economia, e não o inverso.

Como engendrar esforços para que, afinal, a comunidade cívica garanta às localidades o desenvolvimento almejado pelos seus cidadãos? Por onde iniciar, portanto é o que perguntaria Putnam. Ele afirma que buscou colocar neste trabalho apenas um debate sobre "o complexo nexo casual entre as normas e as atitudes culturais e as estruturas sociais e os padrões de comportamento que configuram a comunidade cívica”.

O pesquisador concluiu que não há porque iniciar uma discussão tipo “o ovo ou a galinha" sobre cultura versus estrutura por que isto seria infrutífero, recomendando as considerações de Douglass North sobre o desafio da compreensão do desenvolvimento institucional: 
III. Desenvolvimento Industrial Descentralizado

"A subordinação à trajetória significa que a história realmente importa. É impossível compreender as opções de hoje (e precisá-las na modelagem do desempenho econômico) sem investigar a evolução incremental das instituições. Mas estamos apenas começando a importante tarefa de pesquisar as implicações da subordinação à trajetória (...). As restrições formais realmente importam. Para melhor responder a essas questões, precisamos saber muito mais sobre as normas derivadas da cultura e sobre como elas interagem com as normas formais. Estamos apenas começando a estudar a fundo as instituições. ${ }^{3 "}$

\subsection{Desenvolvimento Industrial na Terza Itália}

$\operatorname{Raud}^{4}$ observou que a industrialização difusa observada na Itália é uma combinação de descentralização industrial e agrupamentos industriais, devendo estas experiências serem consideradas como um projeção particular da industrialização difusa e, embora, a descentralização constitua-se uma de suas características ela, às vezes, pode ser apenas uma fase deste processo.

A industrialização difusa italiana caracteriza-se, por redes de pequenas e médias empresas concentradas em uma determinada cidade, segundo a pesquisadora, sendo cada uma especializada em um estágio do processo de produção de um mesmo tipo de bem e ligada ao mesmo mercado.

Essa descentralização do processo de produção, graças a um acordo de subcontratação entre empresas, permite uma grande flexibilidade e produtividade, onde ao lado dos mecanismos de mercado, encontram-se trocas baseadas na reciprocidade, que consistem em trocas gratuitas de bens e serviços no quadro das relações de amizade, familiares ou comunitárias.

Raud mostra que ao processo de industrialização difusa e de constituição dos chamados "distritos industriais" italianos está relacionado um processo de descentralização produtiva e crescimento das PME (pequenas e médias empresas), onde o papel do Estado foi menos importante que a origem artesanal e as características herdadas do passado, destacando-se entre estas a tradição artesanal, a pequena propriedade agrícola e as famílias extensas, que jogaram um papel decisivo no apoio e alavancagem de iniciativas empresarias de pequeno porte. 
III. Desenvolvimento Industrial Descentralizado

Segundo ela, por estas razões as iniciativas econômicas também receberam o apoio decisivo das instituições locais. Contudo existe grande variabilidade nos mecanismo internos de funcionamento dos distritos industriais, indicando ser a industrialização difusa um processo determinado na sua organização espacial e econômica pela sociedade regional que o suscitou.

As principais características intrínsecas destes distritos são sua flexibilidade, em grande parte baseada em PMEs que funcionam à base de subcontratação, capacidade de inovação, atribuída à criatividade do pessoal diretamente implicado no processo de produção e ao sistema de valores socialmente legitimado pelo orgulho pessoal em estar na vanguarda tecnológica, e sua forte articulação com a população local que faz com que o trabalho seja perpassado por uma dimensão ética de compromisso personalizado entre trabalhadores e empregadores das PME.

A industrialização difusa "não é concebida como fruto do laissez-faire nem o resultado de uma política voluntarista, mas se trata de uma construção social do mercado, de um desenvolvimento apoiado sobre e modelado pelas características sociais", considera a pesquisadora.

Esta forte interação das firmas e do mercado com o ambiente onde se insere dá-se a partir de mecanismos específicos de regulação que são formais e latentes, onde os formais são dados pelas organizações políticas locais, especialmente as agremiações de empresários e trabalhadores e o setor público.

Mas a maior importância está nos mecanismos informais de regulação, e neste sentido a reciprocidade interfirmas assume grande importância., conforme considera Raud. E que, segunda ela, estão assentados em relações de interconhecimento, de amizade, de confiança e de parentesco que têm como base as famílias extensas e em muitos casos estas relações são até mesmo mais importantes que a troca mercantil.

Raud conclui que os distritos industriais italianos também se ressentem dos problemas que afetam outras estruturas industriais como por exemplo a concorrência estrangeira sobretudo asiática aos seus produtos; as conseqüências da reestruturação e da modernização tecnológica com o agravamento do desemprego; o crescimento das pressões sindicais por melhores 
III. Desenvolvimento Industrial Descentralizado

salários e, mais recentemente, das alterações provocadas no ambiente local pela contratação crescente de trabalhadores imigrantes do Magreb e da África.

\subsection{A Competência Industrial de Módena}

Paolo Onesti, Diretor-Presidente da organização não-governamental Democenter de Módena $^{5}$, destaca a competência industrial de Módena. Esta cidade italiana, com uma população de aproximadamente 4.000.000 de habitantes, está localizada em uma das regiões mais ricas da Itália, apresentando uma renda per capita de US\$ 18.000 .

Segundo Onesti, "a industrialização de Módena tem 40 a 50 anos de história, sendo que na região as duas maiores áreas industriais são Mecânica e Eletrônica, que estão juntas, e, também Alimentos, contando basicamente com pequenas e médias empresas: $98 \%$ das indústrias têm menos de 50 trabalhadores e 69\% das empresas e indústrias têm menos de 50 trabalhadores, contribuindo para que a produção local da Emilia Romana alcance algo por volta de $28 \%$ do Produto Interno Bruto da Itália".

O Diretor-Presidente do Democenter refere-se à vantagem locacional de Módena do ponto-de-vista geográfico que contribuiu para que estas indústrias fossem bem distribuídas.

Desta maneira, carros de alta performance, como Ferrari e Maceratti, estão em Módena; maquinário mobiliário e a indústria da madeira estão na região de Rimini, além de setores como indústrias de cerâmica, têxteis, madeireiras e outras que se instalaram na região em busca de uma melhor competitividade.

Ele afirma que estas indústrias não conseguiriam subsistir por si próprias, e contam com a ajuda de universidades técnicas e de escolas secundárias de mecânica e eletrônica para desenvolver e qualificar seus produtos para o mercado global.

Quanto à localização, Onesti considera que "a posição central na Europa ajuda os negócios. Há ainda grandes investimentos em treinamento e tendência à criação de empresas. Esta tendência é muito importante, pois demonstra que as pessoas aceitam fazer investimentos de risco". 


\section{Desenvolvimento Industrial Descentralizado}

A força da indústria na região, ele credita à presença de 24.000 indústrias mecânicas e manufatureiras, que estabelecem uma forte conexão entre empresas e associações, centros de serviços e entidades de estudos e pesquisas, e também ao fato de que este sistema não deixa de lado o lado humano da produção. Sendo umas das razões desta ligação entre organizações e empresas o fato de viverem em ambiente informal e possuírem conexões fortes, pois as pessoas que delas fazem parte nasceram na mesma região, conhecem umas às outras e trocam idéias em um clima de cordialidade.

Onesti diz que teria sido impossível empreender a transformação tão grande nesta região, que até pouco tempo vivia basicamente da agricultura, sem a ajuda de associações, centros de serviços e unidades de estudos e pesquisas, e do apoio vital dado pelas autoridades locais, fortalecendo este aspecto social muito forte na região.

Ele acredita que, atualmente, está ocorrendo uma mudança no sistema econômico da Emilia Romana, que tem um alto número de empresas e forte tendência de criação de negócios: as empresas que começaram informalmente, pequenas, cresceram, e já existem há cerca de 20, 30 anos, agora contam com uma boa presença de investidores estrangeiros. Na captação de recursos externos, destaca-se a área biomédica, com perto de $60 \%$ de investimentos americanos. Onesti vê com otimismo este fato, denotando a importância de agora os pequenos empresários contarem com um mercado em expansão no nível global.

Em termos de organização, o Diretor-Presidente do Democenter, releva um elemento importante: a existência de associações de empresas no sentido vertical e horizontal, favorecendo as empresas que por serem muito pequenas não davam conta de cumprir suas obrigações com impostos e relações governamentais. Neste aspecto, estas associações exercem atualmente um papel muito importante como centros para ajudar as pequenas empresas.

Ele aponta outro ponto importantíssimo: a existência de boa infraestrutura de comunicações, pois a região está situada no meio da Europa, como já foi citado. Não devem ser esquecidos os centros de pesquisas e universidades que também exercem um papel importante. Estas características podem ser encontradas em muitos lugares, mas não com conexões tão fortes. "O que é 
III. Desenvolvimento Industrial Descentralizado

realmente diferente com relação ao país são as agências para inovação e difusão de tecnologia, animação econômica", afirma Paolo Onesti.

Pela originalidade do modo produtivo da região, ele responsabiliza um sistema extremamente complexo de relações entre as empresas e os centros de serviços, criados cada um para cuidar de um setor e que são extremamente horizontais. Todas esses centros de serviços industriais agem como uma interface entre as empresas. Mas não se deve esquecer que nesta cadeia produtiva é importante levar em consideração os fornecedores externos, pois estes são a força maior neste sistema de manufatura. Este aspecto cria a possibilidade de progresso para as empresas menores, que estão à volta. Concretizando, assim, um sistema de redes de produção.

Onesti afirma ser relevante que metade dos fornecedores na região são companhias de alta tecnologia com menos de 20 trabalhadores, os quais são extremamente especializados visando atender estas indústrias independentes. Muito interessante, ele afirma, e que vale ressaltar, é que estes trabalhadores servem não apenas a uma empresa, mas sim a várias ao mesmo tempo, o que provoca uma experiência única: as habilidades vêm de um setor e são aplicadas em outros, havendo uma difusão de conhecimentos.

Ele destaca alguns benefícios destes sistema de industrialização:

- As companhias de tecnologia impulsionam a inovação, qualificam e difundem o setor;

- Muitas destas empresas iniciam suas atividades indo diretamente ao mercado;

- A interatividade que acontece no momento cria um setor virtual em que as habilidades desenvolvidas em setores independentes circulam.

Onesti se pergunta se ele estaria vivendo em um lugar perfeito. Concluindo que, infelizmente isto não era verdade, e aponta alguns problemas do sistema industrial:

- Fatores de risco em pequenas e médias empresas, como, por exemplo, o comportamento independente e individualista; 


\section{Desenvolvimento Industrial Descentralizado}

- Dificuldades de produção e design limitado;

- Falta de tempo e recursos para arcar com processos de engenharia;

- Falta de ferramentas de mercado; e

- Dificuldades no planejamento e controle.

Por que em Módena ainda há necessidade destas ferramentas?

O Diretor-Presidente do Democenter entende que "é preciso continuar conectado com o mundo. Nos últimos cinco anos apareceram novas tecnologias que modificaram a economia e o comportamento num nível global e a Internet era importante, mas se destinava apenas para fornecedores e pessoas especializadas, hoje abriu-se para o público e portanto a informação está mais global. O mercado tornou-se muito volátil. Mas não devemos nos sentir desconfortáveis por estes motivos: estive em Detroit há pouco tempo e o presidente da General Motors colocou os mesmos problemas. Prever o futuro está ficando cada vez mais difícil. Portanto, estes problemas também são compreensíveis para as pequenas empresas. As decisões são influenciadas por um nível crescente de parâmetros. Assim, prever está ficando cada vez mais difícil. Há necessidade de ajudar as pequenas empresas. A informação básica pode ser adquirida com custos decrescentes, mas o conhecimento avançado, que é o mais importante, é bem mais difícil de se obter e bem mais caro. Não é suficiente apresentar conferências a estas empresas, é necessário usar outras ferramentas mais reais".

As idéias de Paolo Onesti estão sendo concretizadas no Democenter de Módena que tem como missão a difusão de inovações em assuntos de manufatura e organizacionais, sobretudo nos campos da automação, informática e telemática e isto tem como alvo as empresas de manufatura, sobretudo as pequenas e médias empresas, os fornecedores de serviços, administrações públicas, centros de serviços e alunos das universidades da região.

Sua organização tem quatro objetivos importantes:

- Fazer crescer a consciência tecnológica;

- Dar apoio à tecnologia, organizando os assuntos e temas de pesquisa; 
III. Desenvolvimento Industrial Descentralizado

- Apoiar uma comunicação melhor com outros assuntos institucionais e econômicos; e

- Dar apoio às empresas quanto aos recursos humanos, o que significa treinamento.

Para apoiar o trabalho do Democenter, as análises de necessidades são feitas duas vezes ao ano, através de grupos de empresas e indústrias, associações, líderes de tecnologia, universidades e grupos de pesquisas e desenvolvimento sobre tendências internacionais. Estas análises não buscam entender como é o know-how, mas sim saber onde encontrá-lo. Para o italiano, a preocupação é identificar a competência tecnológica regional.

E, assim, segundo Onesti, nos últimos três anos tem sido preocupação do Democenter estimular esta consciência tecnológica, aplicando as seguintes ferramentas:

- Demonstração de tecnologia avançada;

- Treinamento tecnológico;

- Pesquisa aplicada e serviços de laboratório;

- Consultoria tecnológica; e

- Apoio para aplicações da informação e do conhecimento tecnológicos. 


\section{Desenvolvimento Industrial Descentralizado}

\section{Industrialização Descentralizada no Brasil}

No Brasil, uma discussão da descentralização industrial está sendo conduzida pelo IPEA (Instituto de Pesquisas Econômicas Aplicadas) que vem monitorando o fenômeno, utilizando a Internet para a constituição de uma Rede de Políticas Industriais Descentralizadas.

Nesta rede virtual se realiza a divulgação das principais experiências de industrialização local, políticas industriais descentralizadas, além de pesquisas, publicações e eventos no âmbito nacional e internacional sobre o tema em questão, com a preocupação de permitir a identificação e acompanhamento de estudos e pesquisas sobre políticas e processos de industrialização localizada.

Segundo constatou o IPEA, este fenômeno recente do processo de industrialização tem sido bem recebido pelos governos centrais em vários países do mundo, pois suas políticas industriais formuladas e implementadas em seus âmbitos vinham apresentando crescentes limitações em virtude do processo de globalização, formação de blocos regionais e, principalmente, das restrições macroeconômicas relacionadas às finanças públicas federais.

No Brasil surgem algumas alternativas às políticas industriais concebidas e implementadas a partir de ações do governo federal, políticas locais e regionais, principalmente, com iniciativas voltadas para pequenas e médias empresas, algumas delas obtendo êxito até mesmo sem qualquer significativo suporte decisivo da ação proveniente do setor público.

Os bons resultado obtidos, apontados por indicadores de crescimento econômico, competitividade internacional e geração de emprego das experiências internacionais de industrialização local, provocaram o interesse de governos, pesquisadores e das comunidades no Brasil. E, assim, algumas das experiências de industrialização localizada já vêem desde os anos 80 , seguindo modelos aplicados nos distritos industriais ${ }^{1}$ europeus que estiveram mais em evidência nos anos 70 .

As experiências brasileiras têm sido razoavelmente documentadas ${ }^{2}$, com pesquisadores voltados à identificação e acompanhamento das ações políticas de industrialização local, pois, embora as políticas de industrialização descentralizadas venham despontando como alternativa concreta às políticas de desenvolvimento industrial centralmente concebidas, graças ao êxito já constatado 
III. Desenvolvimento Industrial Descentralizado

no que se refere à ganhos de competitividade e geração de emprego e renda, não existe uma política clara do governo brasileiro nesta questão.

As comunidades regionais e locais, empresariais e políticas, estão buscando formas de absorver as experiências bem-sucedidas de crescimento econômico baseado no desenvolvimento industrial local e têm procurado uma certa autonomia, característica principal de que se revestem estas experiências, em relação às políticas nacionais elaboradas e coordenadas no âmbito do governo central.

Embora o interesse no tema "Políticas Industriais Descentralizadas", refletido na multiplicação de publicações e eventos (seminários, conferências, "workshops") a respeito do tema, no Brasil e no exterior, demonstre a clara tendência de adoção deste modelo de política industrial de forma generalizada nas regiões com potencial de desenvolvimento local, este ainda não deve deslanchar, como ocorreu em outros países e deve permanecer por algum tempo principalmente no nível de discussão, quer seja pela falta de recursos do governo federal quer seja pelas dificuldades por que passam as administrações municipais, parceiras importantes neste processo.

Porém não é conveniente apenas contemplar o entendimento $\mathrm{e}$ compreensão desses processos de desenvolvimento industrial, mas iniciar etapas iniciais necessárias para a introdução do modelo descentralizado. Seriam as análises internas das localidades, visando determinar a capacidade local de receber as atividades econômicas derivadas do crescimento da atividade industrial, viáveis de serem obtidos através do fortalecimento dos potenciais aglomerados industriais setoriais regionais.

Os aglomerados industriais são caracterizados em regiões delimitadas geograficamente, constituindo-se de concentração de pequenas e médias empresas de um determinado setor ou segmento industrial. Esta concentração geográfica de pequenos e médios produtores viabiliza uma divisão do trabalho entre eles, o estabelecimento de relações de cooperação entre as empresas que irá proporcionar obter ganhos efetivos através de uma eficiência coletiva, que não seriam viáveis com a atuação isolada das empresas. 


\section{Desenvolvimento Industrial Descentralizado}

Existem, de acordo com o IPEA, diversos tipos de processos de industrialização localizada no Brasil que poderiam ser caracterizados segundo o grau de desenvolvimento das interações e articulações entre os agentes produtivos entre si e com os agentes institucionais, ou segundo a morfologia e a definição territorial da experiência.

\subsection{Tipologia de Aglomeração Industrial}

O IPEA, a partir da variedade de situações possíveis observadas nas experiências nacionais e internacionais, propôs a adoção de uma tipologia para a caracterização dos processos de aglomeração industrial especializada. É um interessante ponto de partida, embora ainda deva ser considerado "insuficiente para dar conta das diferenças existentes entre todas as peculiaridades das situações encontradas, mas eventualmente bastante para captar os seus traços essenciais" "3. Os modelos encontrados poderiam, então, serem considerados como:

1. Agrupamento Potencial - há uma concentração de atividades produtivas no local e as empresas têm alguma característica em comum, o que indica existência de tradição técnica ou produtiva, mas, não está consolidada uma organização ou interação entre os agentes daquelas atividades.

2. Agrupamento Emergente - há presença de empresas, de qualquer porte, com característica em comum o que permite $o$ desenvolvimento da interação entre seus agentes. A presença de instituições como centros de capacitação profissional e de pesquisa tecnológica, entre outras instituições setoriais ou comunitárias, facilitam a atividade, mesmo incipiente de articulação ou organização dos agentes locais.

3. Agrupamento Maduro - são encontradas no local condições ideais para a concentração de atividades com característica comum, inclusive a existência de uma base tecnológica significativa, observando-se a existência de relacionamentos dos agentes produtivos entre si e com os agentes institucionais locais. Estes fatores podem estimular a geração de externalidades positivas, 


\section{Desenvolvimento Industrial Descentralizado}

embora seja detectada a presença de conflitos de interesses e/ou desequilíbrios, o que reflete um baixo grau de coordenação.

4. Agrupamento Avançado - as características são as mesmas do agrupamento maduro, porém denota-se alto nível de coesão e de organização entre os agentes.

5. Aglomeração ou "cluster" ${ }^{\prime 4}$ - apresenta características de agrupamento maduro quanto ao grau de coesão, embora com menor organização, referindo-se porém a uma sub-região e envolvendo um número maior de localidades ou áreas urbanas, de modo contíguo e constituindo um espaço econômico pouco diferenciado em termos das atividades produtivas e fatores de produção presentes

6. Pólo Tecnológico ${ }^{5}$ - refere-se àqueles locais em que estão reunidas empresas intensivas em conhecimento, ou de base tecnológica, bem como universidades e/ou instituições de pesquisa. Apresenta características de agrupamento maduro, embora as atividades possam apresentar pouca semelhança, por exemplo em termos setoriais.

7. Redes de Subcontratação - são situações, não necessariamente um local, em que uma ou mais empresas nucleadoras formam em torno de si redes de fornecedores, e que, embora sem se constituírem em um agrupamento, contam com elevado grau de organização, com hierarquia estabelecida pela empresa-núcleo.

\subsection{Algumas Experiências no Brasil}

Compreendida a classificação proposta pelo Instituto federal, seus pesquisadores fizeram uma apresentação de algumas experiências, com objetivo de, em um estágio posterior de conhecimento, identificar políticas a serem direcionadas ao estímulo do surgimento e desenvolvimento de processos de industrialização descentralizadas em outras localidades do território brasileiro. 
III. Desenvolvimento Industrial Descentralizado

A seguir são apresentados relatos efetuados pelo IPEA sobre algumas destas experiências em regiões brasileiras.

\subsubsection{Americana}

A região de Americana é especializada na produção de tecidos, e engloba além da cidade de Americana, as cidades de Santa Bárbara D’Oeste, Nova Odessa e Sumaré, constatou o IPEA. As empresas que atuam na região podem ser consideradas como predominantemente de pequeno e médio porte. Segundo o Instituto do governo federal, o ciclo produtivo na região conta como elemento importante a participação das chamadas "facções", empresas subcontratadas de outras empresas, geralmente da própria região. Estas facções têm representado a forma de ajuste de demanda das empresas maiores, levando a uma forte assimetria e relações conflituosas entre os agentes produtores locais, dificultando a geração de sinergias e a geração de externalidades positivas. $O$ IPEA ressalta a presença de organizações educacionais, voltadas a formação de mão-de-obra qualificada, e de organizações para a promoção de feiras e eventos na região, com o objetivo de promover a indústria local.

De acordo com o IPEA, Americana pode ser caracterizada como um agrupamento maduro. Este agrupamento, com perfil de empresas do setor têxtil, conta com os seguintes agentes participantes:

- Empresas de pequeno e médio porte;

- Sindicato das Indústrias Têxteis de Americana, Santa Bárbara D’Oeste e Nova Odessa (Sinditec);

- Faculdade de Tecnologia Têxtil de Americana - Fatec;

- Escola Técnica Estadual Polivalente de Americana - Etepa;

- Serviço Nacional de Aprendizagem Industrial - SENAI.

\subsubsection{Blumenau}

O IPEA constatou que as empresas do setor têxtil e de vestuário de Blumenau, após o processo de abertura de mercado que representou queda na participação nos mercados internos e externos, começaram a se reestruturar. Assim, foram adotadas basicamente duas estratégias: a primeira delas está representada na redução de preços via demissões, transferência da estrutura 
III. Desenvolvimento Industrial Descentralizado

produtiva para outras regiões do país, e flexibilização da produção via subcontratação da atividade de costura, para as chamadas facções (empresas de pequeno porte, as vezes instaladas nas próprias residências, de municípios vizinhos que têm mão-de-obra mais barata); e a segunda estratégia das empresas está na incorporação de novas tecnologias ao processo produtivo, mas principalmente na utilização de tecidos 'tecnológicos' (de última geração) e de design moderno, procurando se inserir em outro nicho de mercado consumidor, através de estratégias de marketing, baseada na criação e/ou consolidação de marcas, e de redes de franquias, foi o que constatou o Instituto do governo federal em seus levantamentos. Estas estratégias levaram a Associação Comercial e Industrial de Blumenau em conjunto com o SENAI e a FURB a promover a criação da Fundação Blumenau Fashion, arranjo institucional voltado à capacitação tecnológica do setor, especialmente na etapa de confecção; e a criação de uma marca de identificação da região, para permitir a adoção de estratégias de maior agregação de valor também às pequenas e médias empresas.

De acordo com a classificação do IPEA, Blumenau pode ser caracterizada como uma rede de subcontratação no setor têxtil e vestuário, tendo como agentes participantes:

- Empresas do setor têxtil - vestuário;

- Associação Comercial e Industrial de Blumenau;

- Serviço Nacional de Aprendizagem Industrial - SENAI;

- Serviço de Apoio às Micro e Pequenas Empresas de Santa Catarina - SEBRAE/SC;

- Fundação Universidade Regional de Blumenau - FURB;

\subsubsection{Campinas}

\section{a. Telecomunicações e Informática}

Os setores de equipamentos para telecomunicações e informática, estão caracterizados por empresas de pequeno, médio e grande porte na cidade de Campinas, devendo-se ressaltar que as empresas de maior porte são, em geral, filiais de empresas multinacionais, segundo o IPEA. A alta infra-estrutura científico-tecnológica existente na cidade poderia significar a formação de 
III. Desenvolvimento Industrial Descentralizado

parcerias, e garantir um fluxo de conhecimentos e informações entre os agentes participantes do arranjo. No entanto, não há interação freqüente, ou regular, entre as empresas de maior porte e as universidades ou instituições de pesquisa. Os relacionamentos de caráter científico-tecnológico que se formam na região se formam através da mão-de-obra destas empresas, egressa das universidades locais, ou são spin-offs de grandes empresas instaladas na cidade desde a década de 70. Os outros relacionamentos existentes entre estas empresas e as organizações de pesquisa locais se dão 'por força' da Lei de Informática, criada após o fim da reserva de mercado destes setores. De forma semelhante, a presença de pequenos e médios produtores nestes setores poderia representar a constituição de uma rede de fornecedores para as empresas maiores (e que de fato constituíram durante o período da reserva de mercado). Mas, de acordo com observações do IPEA, as empresas multinacionais que se instalaram em Campinas depois da liberalização da economia brasileira utilizam uma estratégia de atração de seus fornecedores a nível mundial para a região, ou importam a maioria de seus insumos (global sourcing), formando pouco ou nenhum vínculo com as empresas fornecedoras da cidade. Apesar disso, considera o IPEA, que a presença destes agentes na região pode ser potencializada através de uma ação, pública e/ou privada, para a constituição de uma rede de interação entre empresas, organizações de pesquisa, e instituições locais, que resultaria na geração de externalidades positivas, e criaria um ambiente favorável ao desenvolvimento das empresas instaladas na região.

Desta maneira, Campinas pode ser caracterizada como um agrupamento emergente de empresas de telecomunicações e de informática, onde os agentes participantes são:

- Empresas de produtoras de equipamentos de telecomunicações e de informática;

- Universidade Estadual de Campinas - UNICAMP;

- Pontifícia Universidade Católica de Campinas - PUCCAMP;

- Laboratório Nacional de Luz Síncotron - LNLS;

- Centro de Tecnologia de Informática - CTI; 
III. Desenvolvimento Industrial Descentralizado

- Centro de Pesquisa e Desenvolvimento - CPqD/ Telebrás;

- Secretaria de Cooperação Internacional do Município de Campinas.

\section{b. Pólo Tecnológico}

Detectou o IPEA, ainda em Campinas, um interessante pólo tecnológico que começou a ser desenvolvido durante a década de 70, a partir da iniciativa de organizações locais, como a UNICAMP, e de autoridades locais. A idéia surgiu da observação de casos como o Silicon Valley americano, e da tentativa de se aproveitar a infra-estrutura de C\&T da região. Em 1983 foi criado o Ciatec, cujo objetivo principal é estabelecer a ligação entre as universidades e institutos de pesquisa com as empresas de alta tecnologia da região, e estimular a criação/instalação de outras empresas de tecnologia em Campinas. Iniciou-se a formação do pólo tecnológico de Campinas, que tem empresas de capital nacional e estrangeiro dos ramos de informática, microeletrônica, telecomunicações, optoeletrônica e química fina. O IPEA ressalta a presença de inúmeras empresas de software de pequeno e médio porte, ligadas inclusive ao programa de desenvolvimento de software para a exportação do governo federal - Programa Softex. Além disso, observa o Instituto do governo federal, há a presença de um organismo voltado para o estímulo à exportação - o Trade Point, e o Programa de Incubadoras Empresariais voltado às empresas de base tecnológica, que completam a estrutura institucional do pólo tecnológico.

Desta forma, de acordo com o IPEA, Campinas também pode ser caracterizada como um pólo tecnológico, tendo como agentes participantes:

- Empresas de setores de alta tecnologia;

- Universidade Estadual de Campinas - UNICAMP;

- Pontifícia Universidade Católica de Campinas - PUCCAMP;

- Instituto Agronômico de Campinas - IAC;

- Instituto de Tecnologia de Alimentos - Ital;

- Centro de Tecnologia de Informática - CTI;

- Centro de Pesquisa e Desenvolvimento - CPqD/Telebrás; 


\section{Desenvolvimento Industrial Descentralizado}

- Laboratório Nacional de Luz Síncotron - LNLS;

- Companhia de Desenvolvimento do Pólo de Alta Tecnologia de Campinas - Ciatec.

\subsubsection{Colatina}

O IPEA levantou mais de 200 empresas do setor de vestuário existentes no local filiadas ao Sindicato da Indústria de Confecções de Colatina, responsáveis por um faturamento total de aproximadamente $\mathrm{R} \$ 18$ milhões/mês, com a geração de mais de 5 mil empregos diretos. Uma das ações deste sindicato foi constituir um Centro de Pesquisa de Moda com o objetivo de motivar e viabilizar a inovação, que tem sido amplamente utilizado pelas empresas permitindo, além da redução do desperdício de matéria-prima e de produção ("peças encalhadas"), maior flexibilização da produção por parte das empresas e a inovação, especialmente em termos de produto. Houve também por parte do BANDES a abertura de uma linha de crédito para micro, pequenas e médias empresas, inclusive de setores tradicionais, com o objetivo de estimular a inovação - Programa de Apoio ao Desenvolvimento Tecnológico do Espírito Santo (PADTES), porém, segundo o IPEA, foi pouco utilizado pelas empresas tradicionais. O CETECON - Centro Tecnológico das Indústrias de Confecção do Espírito Santo - também tem sido pouco utilizado, atribuindo-se esta dificuldade à deficitária estrutura gerencial do setor, basicamente constituído de empresas pequenas e familiares de vestuário.

Colatina pode ser caracterizada como um agrupamento emergente de empresas de vestuário, segundo as classificações do IPEA, tendo como agentes participantes:

- Empresas de pequeno e médio porte produtoras de vestuário;

- Sindicato da Indústria de Confecções de Colatina;

- Centro Tecnológico das Indústrias de Confecção do Espírito Santo (CETECON);

- Banco do Estado do Espírito Santo (BANDES).

\subsubsection{Criciúma}


III. Desenvolvimento Industrial Descentralizado

Nesta cidade catarinense, o processo iniciou com a criação do Centro de Tecnologia em Cerâmica por iniciativa dos produtores locais, a partir da observação de experiências similares nos países líderes na produção de cerâmica para revestimento (Espanha e Itália). Segundo o IPEA, a qualificação do agrupamento foi planejada a partir da queda na participação no mercado interno, causada pela ascensão de empresas de outras regiões do país, localizadas por exemplo no interior de São Paulo, com matérias-primas de qualidade superior, e maior proximidade ao principal mercado consumidor do país (região sudeste). $\mathrm{O}$ objetivo primeiro do centro foi a solução de problemas no processo produtivo, com a qualidade da matéria-prima, diminuição do desperdício produtivo, atualização tecnológica, desenvolvimento de capacitação local e qualificação da mão de obra. Para a fundação do CTC, observou o IPEA, foram fundamentais as participações da Funcitec, através do aporte de recursos; da UFSC, através principalmente do Laboratório de Materiais (Labmat) do Departamento de Engenharia Mecânica, com a qualificação e capacitação para o suporte científicotecnológico; e do Sindiceram, como representante dos interesses das empresas produtoras de cerâmica de revestimento. A criação do CTC possibilitou a realização de testes e ensaios de materiais, e a certificação de qualidade das empresas a nível internacional, além da criação de uma rede de fornecedores e de usuários cerâmicos que se utilizam também da estrutura do centro. Atualmente, o projeto evoluiu para a criação de uma estrutura de ensino superior na Universidade do Extremo Sul Catarinense (Unesc) - o curso superior em tecnologia cerâmica, que tem a participação da UFSC, FIESC e Sindiceram, além dos cursos de curta duração ministrados pelo próprio CTC. O projeto de criação do CTC, de acordo com o IPEA, tornou-se bastante interessante por ter formado um elo cooperativo em toda a cadeia produtiva de cerâmica para revestimento, com a participação da universidade, e de organizações empresariais, com geração de externalidades positivas e potencialização da competitividade das empresas locais.

Um agrupamento avançado de empresas de cerâmica seria a classificação de Criciúma, conforme verificou o IPEA, tendo como agentes participantes: 


\section{Desenvolvimento Industrial Descentralizado}

- Empresas de médio e grande porte produtoras de cerâmica de revestimento;

- Centro de Tecnologia em Cerâmica-CTC;

- Universidade Federal de Santa Catarina - UFSC;

- Serviço Nacional de Aprendizagem Industrial - SENAI;

- Federação das Indústrias do Estado de Santa Catarina - FIESC;

- Sindicato das Indústrias de Cerâmica - Sindiceram;

- Fundação de Ciência e Tecnologia - Funcitec (órgão ligado à Secretaria do Estado do Desenvolvimento Econômico, Científico e Tecnológico).

\subsubsection{Florianópolis}

O IPEA considera que o pólo tecnológico de Florianópolis começou a se formar na década de 70 e foi concretizado na década de 90, através do projeto Tecnópolis, do governo do estado, que tinha como principal objetivo a articulação universidade - indústria, com fins de aproveitar a estrutura científica e tecnológica e a capacitação da região. A institucionalização do Conselho das Entidades Promotoras da Tecnópolises - Contec - com a participação de 25 organismos de apoio, muitos deles ligados ao governo do Estado, possibilitou a formação do arranjo. O IPEA constatou ainda que o objetivo do pólo é aproveitar as potencialidades das empresas de software e hardware já instaladas, aumentando a sua capacidade através da articulação entre estas, e entre estas e a universidade.

Pretende-se com o pólo também contribuir para a formação de novas empresas de software e de base tecnológica, objetivo a ser atingido a partir da formação do CELTA, a fim de se aproveitar as potencialidades da região, e aumentar a geração de externalidades positivas. De acordo com o IPEA, houve aporte de recursos para financiamento de novas empresas de pequeno e médio portes, realizado pelo sistema FIESC-SENAI e pelo governo do estado, através da criação de incentivos, especialmente para empresas da área de informática, e da formação do CTAI - Centro de Tecnologia em Automação e Informática. 
III. Desenvolvimento Industrial Descentralizado

Florianópolis é caracterizada como um pólo tecnológico, conforme a classificação realizada pelo IPEA, e tem como agentes participantes:

- Empresas de pequeno e médio portes de software e hardware;

- Universidade Federal de Santa Catarina - UFSC;

- Fundação Centros de Referência em Tecnologias Inovadoras Fundação CERTI;

- Centro Empresarial para a Laboração de Tecnologias Avançadas CELTA;

- Condomínio Industrial de Informática da Associação Catarinense de Telemática - ACATE;

- Serviço Nacional de Aprendizagem Industrial - SENAI;

- Federação das Indústrias do Estado de Santa Catarina - FIESC.

\subsubsection{Franca}

O IPEA observou que a indústria coureiro-calçadista do estado de São Paulo está localizada em três cidades: Franca, especializada em calçados masculinos; Birigüi, especializada em calçados infantis; e Jaú, especializada em calçados femininos. Franca é a maior produtora de calçados do estado, e a que possui maior infra-estrutura de serviços para a indústria, como o Centro de Tecnologia de Couro e Calçados do IPT, que está sediado na cidade. Segundo o IPEA, a estrutura industrial das três cidades é semelhante, guardadas as proporções. Sendo esta estrutura baseada, principalmente, em empresas de pequeno e médio portes, especializadas na confecção de calçados, com a presença de várias empresas prestadoras de serviços, e empresas especializadas em etapas específicas da produção, além de fornecedores de equipamentos novos e usados e de matérias-primas. O IPEA ressalta entre os prestadores de serviços e as empresas especializadas as "bancas" de pesponto e os "ateliês" de modelagem. A etapa do pesponto é terceirizada pelas empresas de confecção, que podem, então, ser mais flexíveis em sua produção de acordo com a demanda. Os escritórios de exportação, segundo o IPEA, são outra característica importante do local, já que são o meio de ligação das pequenas e médias empresas ao mercado internacional, e determinam o design e as quantidades da produção. 
III. Desenvolvimento Industrial Descentralizado

A caracterização de Franca é de um agrupamento maduro de empresas do setores de couro e calçado, conforme a classificação proposta pelo IPEA, sendo os agentes participantes:

- Empresas dos setores de couro e calçados;

- Escritórios de exportação;

- Centro de Tecnologia de Couro e Calçados (CTCC) do Instituto de Pesquisas Tecnológicas (IPT);

- Serviço Nacional de Aprendizado Industrial (SENAI).

\subsubsection{Santa Cruz do Sul}

Congregando os municípios de Santa Cruz do Sul, Venâncio Aires e Vera Cruz e suas estruturas produtivas, no Vale do Rio Pardo estão baseadas empresas de grande (a maioria de capital internacional), médio e pequeno portes, e de pequenos produtores de fumo em folha, conforme levantamentos do IPEA. Segundo o Instituto do governo federal, estes produtores de fumo tem um relacionamento peculiar com as grandes empresas (principalmente), caracterizado pela exclusividade no fornecimento do fumo em folha, com a garantia da compra de toda a produção, e pela obrigação em seguir o padrão de produção da empresa, em termos de insumos, tipos de fumo, tecnologia de produção, etc. As pequenas e médias empresas também estabelecem relações de fornecimento com as grandes empresas. Em termos dos relacionamentos com as instituições locais, as grandes empresas se envolvem no apoio a questões gerais, de interesse da comunidade local, como a recuperação do meio ambiente, por exemplo, mas não realizam nenhum tipo de pesquisa ou desenvolvimento tecnológico relativo às suas tecnologias de produto ou processo. O IPEA ressalta que a Universidade de Santa Maria, apesar de não fazer parte da região mantém relacionamentos com as grandes empresas na formação de mão de obra, e na realização de testes e certificação de produtos. Porém, apesar de forte, a associação da indústria com os produtores de fumo em folha não apresenta caráter inovativo e as grandes empresas não se mantém integradas ao ambiente local. 
III. Desenvolvimento Industrial Descentralizado

Uma rede de subcontratação agro-industrial caracteriza Santa Cruz do Sul, conforme a classificação proposta pelo IPEA, tendo como agentes participantes:

- Empresas de processamento de fumo e de fabricação de cigarros;

- Estabelecimentos agrícolas para a produção do fumo em folha;

- Associação dos Fumicultores do Brasil - Afubra;

- Sindicato das Indústrias de Fumo - Sindifumo;

- Associação Brasileira de Fumo - Abifumo;

- Sindicato dos Trabalhadores Rurais - STR's;

- Universidade de Santa Cruz do Sul (sedia o Pólo de Modernização Tecnológica do Vale do Rio Pardo);

- Universidade Federal de Santa Maria;

- Centro Tecnológico da Embrapa;

- Centro Tecnológico da Emater;

- Centro de Treinamento do SENAI (Serviço Nacional de Aprendizagem Industrial);

- Conselho Regional de Desenvolvimento do Vale do Rio Pardo.

\subsubsection{Santa Rita do Sapucaí}

O movimento de industrialização da cidade, começando na década de 1950, através da ação individual de uma cidadã que criou em Santa Rita do Sapucaí a Escola Técnica de Eletrônica (ETE): A senhora Luiza Rennó Moreira, natural da cidade que circulava nos meios políticos, inclusive a nível federal, foi quem teve a iniciativa esta idéia que foi financiada e apoiada por ela. Segundo o IPEA, ela pretendia promover o desenvolvimento e criar alternativas à cidade, até então essencialmente agrícola. A proximidade de Santa Rita à cidade de Itajubá propiciou a articulação entre a Escola Federal de Engenharia de Itajubá (EFEI) e a ETE que resultou na formação do INATEL. Tanto a Escola Técnica como o INATEL sempre mantiveram forte articulação com o setor empresarial, tanto a nível local como a nível nacional, estabelecendo parcerias com grandes empresas, 
III. Desenvolvimento Industrial Descentralizado

especialmente no setor de telecomunicações, como a Telemig (Telecomunicações de Minas Gerais), e com instituições de pesquisa, como por exemplo o Centro de Telecomunicações da Pontifícia Universidade Católica do Rio de Janeiro (PUC $\mathrm{RJ}$ ), ou o Centro de Pesquisas da Telebrás (CPqD). A articulação com as empresas da região aliada a crise de emprego da década de 80, fez com que aumentasse a geração de spin-offs das instituições de ensino e, consequentemente, a formação de pequenas e médias empresas na área de eletrônica e telecomunicações, constatou o Instituto do governo federal. A partir daí os setores educacionais e empresariais promovem, com apoio da prefeitura, a realização de feiras de produtos e tecnologia na cidade, e a planejar a criação de mini-distritos industriais voltados às empresas de eletrônica.

Santa Rita do Sapucaí pode ser caracterizada como um agrupamento maduro de empresas de telecomunicações e eletrônica, de acordo com a classificação proposta pelo IPEA, tendo como agentes participantes:

- Escola Técnica de Eletrônica "Francisco Moreira da Costa" ETE;

- Instituto Nacional de Telecomunicações - INATEL;

- Faculdade de Administração e Informática - FAI;

- Pequenas e médias empresas de eletrônica;

- Prefeitura de Santa Rita do Sapucaí.

\subsubsection{São Carlos}

De acordo o IPEA, São Carlos é um pólo tecnológico formado por empresas de base tecnológica (EBT's), que atuam nos setores de eletrônica, mecânica de precisão, novos materiais, informática e instrumentação. $\mathrm{O}$ pólo se constitui de microempresas e empresas de pequeno e médio portes que contam com algumas organizações de apoio e fomento, instituições de pesquisa e Universidades. A Fundação ParqTec ${ }^{6}$, com o objetivo de consolidar o pólo, criou duas incubadoras de empresas: o Centro Incubador de Empresas Tecnológicas CINET, com empresas nas áreas de instrumentação, mecânica de precisão, microeletrônica, robótica, automação e novos materiais; e o Centro Incubador de Empresas de Software - SOFTNET, para empresas de software, integrado ao 
III. Desenvolvimento Industrial Descentralizado

programa para desenvolvimento de softwares para exportação do governo federal - SOFTEX. Segundo o IPEA, as empresas apresentam forte interação com as Universidades locais e entre si, formando, em alguns casos, parcerias para o desenvolvimento de produtos e processo, ou formando relações clientefornecedor. Há também a presença da Associação das Empresas Nascentes uma organização para apoio e fomento das novas empresas de base tecnológica, que estimula a ligação destas com as empresas de mesmo porte da cidade, tendo como objetivo um projeto conjunto para o desenvolvimento econômico local, finaliza o Instituto do governo federal em seu levantamento.

São Carlos, conforme a classificação do IPEA, tem a caracterização de um pólo tecnológico onde os agentes participantes são:

- Fundação Parque de Alta Tecnologia de São Carlos - Fundação ParqTec;

- Centro de Desenvolvimento de Indústrias Nascentes - CEDIN;

- Associação das Empresas Nascentes;

- Universidade Federal de São Carlos - UFSCar;

- Universidade Estadual de São Paulo - Campus de São Carlos USP - São Carlos;

- Empresas de base tecnológica;

- SEBRAE - São Carlos;

\subsubsection{Vale dos Sinos}

Vale dos Sinos é uma região gaúcha que engloba as cidades de Novo Hamburgo, São Leopoldo, Sapucaia do Sul, Sapiranga, Parobé e Taquara. Segundo o IPEA, o setor coureiro-calçadista do Vale dos Sinos está baseado em empresas fabricantes de calçados de couros femininos e tem ao seu redor várias empresas que compõem a cadeia produtiva do setor, como: curtumes e empresas beneficiadoras de couro e peles; empresas fabricantes de componentes para calçados (metálicos, pano, borracha, sintético, etc.); empresas fornecedoras de máquinas e equipamentos; empresas prestadoras de serviços de transporte e exportação. 
III. Desenvolvimento Industrial Descentralizado

O levantamento do IPEA constatou que em torno desta estrutura formou-se uma estrutura organizacional com 6 associações industriais, 2 associações profissionais, 1 empresa organizadora de eventos, 4 centros tecnológicos para a prestação de serviços especializados e treinamento de mão de obra, além das escolas técnicas e escolas de nível superior existentes na região.

Porém, segundo o Instituto do governo federal, apesar da presença destas organizações e da infra-estrutura local, há dificuldades na formação de um ambiente cooperativo entre os agentes, inclusive entre as empresas produtoras de calçados e as fornecedoras de insumos e equipamentos. Outro problema observado por ocasião da pesquisa foi o processo de abertura econômico e da consolidação da China como maior exportador de calçados para o mercado norteamericano (principal mercado das empresas do Vale dos Sinos) que resultou em queda na participação das empresas no mercado interno e no mercado internacional.

O Vale dos Sinos é caracterizado pela classificação aplicada pelo IPEA como um “cluster", ou seja, uma aglomeração de empresas dos setores de couro e calçados tendo como agentes participantes:

- Empresas dos setores de couro e calçados;

- Empresas fornecedoras de máquinas e equipamentos para os setores de couro e calçados;

- Empresas prestadoras de serviços de transporte e exportação;

- Associações Industriais;

- Associações profissionais;

- Empresa organizadora de feiras e eventos;

- Centros tecnológicos;

- Escolas Técnicas e Cursos de Nível Superior.

\subsubsection{Votuporanga}

O levantamento do IPEA apontou na cidade de Votuporanga uma estrutura produtiva baseada em pequenas e médias empresas produtoras de móveis e a especialização das empresas em etapas específicas do processo de produção. $O$ 
III. Desenvolvimento Industrial Descentralizado

arranjo que se estabelece entre os produtores locais e que chama a atenção pela organização e pela participação das organizações locais ligadas à indústria, como a Associação Industrial e o Sindicado da Indústria, promoveram a institucionalização do Pólo Moveleiro de Votuporanga, observou o Instituto do governo federal. O Pólo tem como principais objetivos: o desenvolvimento de programas compartilhados de certificação de qualidade; a implantação de um centro de tecnologia para a indústria moveleira e a instalação de uma unidade do Serviço Nacional de Aprendizagem Industrial (SENAI). Segundo o IPEA, o Pólo participa, ainda, de dois programas do governo federal que têm por objetivo a promoção de investimento e transferência de tecnologia e a inserção das empresas locais no mercado internacional. Esta série de ações determina, então, forte potencial para a geração de externalidades positivas, a partir, principalmente, da cooperação que se estabelece entre os agentes participantes do processo, concluiu o IPEA.

Votuporanga tem uma caracterização de agrupamento avançado de empresas produtoras de móveis, segundo a classificação proposta pelo IPEA, tendo como agentes participantes:

- Empresas de pequeno e médio porte produtoras de móveis;

- Associação Industrial de Votuporanga - AIRVO;

- Sindicato da Indústria Mobiliária de Votuporanga - SINDIMOB. 
III. Desenvolvimento Industrial Descentralizado

\section{Os Pólos Tecnológicos}

Os levantamentos do IPEA no relato sobre a descentralização industrial no Brasil identificam como pólos tecnológicos algumas cidades, como Florianópolis, São José do Rio Preto, Campinas e São Carlos, graças ao potencial de inovação tecnológica que suas articulações institucionais potencializam.

Por sua conexão direta com a transformação do modo produtivo da "Nova Economia", este formato de industrialização localizada é abrangido de uma forma mais extensiva, buscando encontrar parâmetros que o relacionem aos processos de planejamento do desenvolvimento econômico local, objeto de estudo desta tese.

\subsection{Conceito}

Pode-se afirmar que o termo pólo tecnológico designa "regiões de potencial tecnológico intenso, como decorrência da existência de universidades, institutos de pesquisa e de empresas de tecnologia de ponta, geradas a partir desse potencial" . Mas, afinal, como seria a estratégia a ser aplicada, perante um mundo globalizado, para a criação de pólos tecnológicos ${ }^{2}$ ?

Ao longo dos anos, o conceito de pólo tecnológico vem sofrendo uma evolução, desde sua concepção, em 1949, quando a Universidade de Stanford, ao incorporar uma área ao lado de seu campus, criou um parque tecnológico para onde foram grandes empresas como a Kodak e Hewlett-Packard. Estas empresas foram os principais suportes de evolução do pólo tecnológico do Vale do Silício, uma alusão ao material usado nos chips eletrônicos, em seu início, pelas suas grandes capacidades de criar uma sinergia crescente - spin-off - entre os pesquisadores acadêmicos, que passaram se sentir estimulados a participar de projetos conjuntos concretos idealizados para estas grandes empresas.

O sucesso do projeto, promovido pela Universidade e que hoje agrega 3.000 empresas de alta tecnologia na região que vai de Palo Alto a São Francisco, encorajou iniciativas semelhantes pelo mundo todo.

Conhecidos nos EUA e Inglaterra como Science Parks, na língua inglesa eles vêm ganhando outras denominações, tais como: Research Parks, 
III. Desenvolvimento Industrial Descentralizado

Technology Centre e Innovation Centre. Também são designados como: Technopoles na França, Cidades Tecnológicas no Japão, Centros de Inovação Tecnológica na Alemanha e Pólos Tecnológicos no Brasil ${ }^{3}$.

\subsection{Histórico}

Praticamente todas as experiências de pólos tecnológicos vêm se modelando pelos mesmos padrões aplicados desde 1949 pela Universidade de Stanford, quando esta universidade lançou o Parque Tecnológico de Stanford que nos seus 660 acres, próximo ao campus, oferecia indiscutíveis vantagens básicas para projetos industriais não poluentes em sua área, um local extremamente aprazível com acesso fácil aos conhecimentos da universidade.

Graças a incrível sinergia entre o conhecimento e as necessidades do mercado, em 1980 já existiam cerca de 80 empresas de alto nível tecnológico, estimuladas pelas plantas industriais pioneiras da Kodak, Hewlett-Packard. Foram elas as principais responsáveis pelo spin-off provocado entre pesquisadores e executivos da informática que resultou nas pequenas empresas de origem acadêmica que criaram vida própria, através de um mercado que se expandia na mesma velocidade que os processadores aumentavam seu performance.

A explosão na região aconteceu nos anos 90, quando a indústria de informática obteve um vertiginoso crescimento globalizado que transformou definitivamente o Vale do Silício em um grande pólo de desenvolvimento com mais de 3.000 empresas de alta tecnologia que se espalharam na região que vai de Palo Alto à Baía de S. Francisco na Califórnia.

Analistas procuram justificar as razões desse grande sucesso tecnológico como devido a presença de grandes empresas que estimularam e continuam a estimular a sinergia com a Universidade de Stanford, mas também graças à presença de um grande número de pequenas empresas oriundas do meio acadêmico com enorme potencial de inovação. Existem ainda os indiscutíveis fatores locacionais como o sistema viário da região e a excelente qualidade de vida local. Um outro importante dado é que a administração do Parque, completamente independente da Universidade, tem seu gerenciamento cotidiano 
III. Desenvolvimento Industrial Descentralizado

com ritmo empresarial, buscando um constante envolvimento das empresas iniciais com as novas empresas que surgem.

O que ninguém coloca em dúvida é que o projeto alterou o futuro não apenas de toda uma região e do meio universitário americano, mas a forma de ver o uso da tecnologia para promover o desenvolvimento regional. O que seria aplicado em muitas regiões do planeta, e em algumas com sucesso.

\subsection{O Modelo de Sophia Antipolis}

De forma a compreender em detalhes a estruturação de um pólo tecnológico internacional, toma-se o modelo francês de Sophia Antipolis ${ }^{4}$ como referência por se tratar de uma bem-sucedida estratégia de desenvolvimento local em uma região tradicionalmente de vocação turística, aparentemente sem fatores locacionais atraentes para a logística de empreendimentos de alta tecnologia.

\subsubsection{Introdução}

O Tecnopoles de Sophia Antipolis ocupa uma superfície de 2.300 Hectares e é situada na Costa Azul, entre Cannes e Nice.

Sophia Antipolis converteu-se em um nome de projeção no mundo da alta tecnologia desde sua criação há cerca de 30 anos, como seu modelo de pólo tecnológico que apresentava três características fundamentais:

- Qualidade de vida de alto nível reconhecida internacionalmente;

- Uma excelente rede de telecomunicações;

- Uma produtividade crescente constante.

O Tecnopoles de Sophia Antipolis foi projetado com 2.300 hectares para o estabelecimento de 400 empresas e 9.000 postos de trabalho, entretanto já atingia, em 1999, 1.164 companhias, empregando 20.530 engenheiros e técnicos, além de 5.000 pesquisadores e estudantes.

\subsubsection{Políticas, objetivos e instrumentos}

A primeira idéia para conceber o Technopoles de Sophia Antipolis surgiu em um artigo publicado pelo jornal Le Monde em 1960: “Um Quartier 
III. Desenvolvimento Industrial Descentralizado

Latin no Campo: Criação de um Comitê para o Desenvolvimento Urbano e Rural".

Em 1972 esta visão se formalizou com a criação do Syndicat Mixte pour 1'Aménagement et 1'Equipement du Parc de Sophia Antipolis (SYMIVAL) órgão para unir forças de cinco municípios onde se deveria implantar o Tecnopoles, juntamente com o "conseil général" e a Câmara de Comércio de Niza, que foi o órgão encarregado de promover e implantar o pólo tecnológico.

O Colégio Internacional de Valbonne foi criado em 1976 para dar uma docência bilingüe, que foi fundamental para conseguir a atração de empresas estrangeiras à Sophia Antipolis.

Com a participação de $51 \%$ pelo Conseil Général e de $49 \%$ pela Câmara de Comércio, dirigida à promoção, comunicação, comercialização e gestão do Tecnopoles, criou-se a Société Anonime d'Economie Mixte (SAEM) em 1988.

\subsubsection{Infra-estrutura e Organização}

O espaço de 2.300 hectares, definido como a zona de desenvolvimento do parque em 1972, foi denominado Zone d'Aménagement Diféré (ZAD) e é gerenciado de forma integral pelo SYMIVAL que tem o controle do espaço urbanizado. Um proprietário particular de um terreno na ZAD não pode vender sem a concordância do SYMIVAL, organismo que tem direito de compra sobre os terrenos, sendo que os preços de compra são estabelecidos pela Administração Pública.

A SAEM delimita espaços denominados Zone d'Aménagement Concerté (ZAC), com regras urbanísticas estritas que fornece a orientação para projetos arquitetônicos de construção. É esta entidade que instala as infraestruturas viárias e de telecomunicações em cada ZAC para depois negociar a venda de terrenos. Cada uma delas possui suas próprias regras arquitetônicas, definidas através de orientações básicas respeitadas em todas as ZACs.

Uma exigência é que a superfície total de construção não ultrapasse $30 \%$ da área do terreno, com uma altura máxima de três andares. O coeficiente de ocupação do solo é de $45 \%$, incluindo edifícios, estacionamentos e vias de acesso. 
III. Desenvolvimento Industrial Descentralizado

Para a organização do Tecnopoles de Sophia Antipolis, o trabalho da SAEM possui quatro fundamentos:

- Ordenação do parque mediante a compra dos terrenos dentro da ZAD e a definição das pautas arquitetônicas de cada ZAC;

- Promoção e comercialização do parque mediante assistência a conferências, organização de missões ao exterior e o desenvolvimento dos contatos com associações empresariais internacionais;

- Comercialização dos terrenos com empresas e com promotores que desejam construir;

- Gestão e manutenção do parque, espaços verdes, vias e edifícios públicos, mediante a subcontratação destas atividades com empresas especializadas.

Sob o controle do SYMIVAL a SAEM realiza seu trabalho entregando mensalmente um informe de atividade aos membros que aprovam as ações a desenvolver. A atuação da SAEM é fundamentada em estimular a dinâmica do Tecnopoles através de investimento e na atração de empresas:

\section{Financiamento}

Sophia Antipolis investiu, até 1995, mais de US\$ 229 milhões desde sua criação. Deste total, $15 \%$ foi financiado por subvenções do Estado e do Conseil Général des Alpes-Maritimes. Os investimentos realizados pelo Conseil Général des Alpes-Maritimes foram destinados à construção de infra-estruturas viárias, estudos e outros investimentos como edifícios públicos, escolas, etc. Da atividade comercial de venda de terrenos vieram os $85 \%$ restantes.

\section{Segmentos industriais e de serviços do Tecnopoles}

Os segmentos-chave são:

- Tecnologia da informação, eletrônica, e telecomunicações avançadas;

- Ciências médicas e químicas, e química avançada;

- Biotecnologia; 
- Ciências naturais; e

- Educação universitária, treinamento, e pesquisa

\section{Formação da Mão-de-Obra}

A SAEM em colaboração com a Universidade de Niza e os institutos de pesquisa já implantados em Sophia, esforçaram-se no desenvolvimento da formação da mão-de-obra para fazer de Sophia Antipolis um centro do conhecimento líder. $\mathrm{Na}$ atualidade, 5.000 pessoas, entre estudantes e pesquisadores atuam no Tecnopoles, com previsões de 8.000 estudantes para o ano 2010 .

Para alcançar este objetivo criou-se a ZAC "Fugueret", situada à entrada do parque sobre um terreno de 30 hectares que tem permitido desde 1993 a execução de vários projetos:

- Construção de um instituto universitário de tecnologia.

- Extensão da Universidade de Niza.

- Extensão da escola de negócios CERAM.

- Extensão do campus do Euro-American Instituto, universidade franco-americana fundada pela Florida Instituto of Technology.

- Projeto de criar Sophia Institut of Technology no modelo do MIT com especialização em informática.

\subsubsection{Conclusão}

Os consultores da Andersen Consulting concluíram que "Sophia Antipolis tem se convertido em um centro inovador consolidado, desenvolvido a partir da eficiente concentração de empresas, centros de pesquisa e centros de formação relacionados com a inovação tecnológica".

Apresentaram, ainda, os técnicos da empresa internacional, as razões do sucesso do pólo francês, baseando-se em pesquisas que a SYMIVAL encomendou, a um instituto privado, sobre o grau de satisfação dos dirigentes e executivos em Sophia.

A lista dos principais motivos pelos quais as empresas resolveram instalar-se em Sophia são: 


\section{Desenvolvimento Industrial Descentralizado}

- Proximidade de um aeroporto internacional com relação direta a vários destinos do mundo;

- Infra-estruturas de telecomunicações avançadas;

- Cooperação entre as empresas através dos clubs de "fertilización";

- Maior produtividade dos profissionais;

- Disponibilidade de profissionais de alta qualificação;

- Presença de centros universitários de alto nível, mesmo com a falta de colaboração mais estreita entre a universidade e as empresas;

- Vida social e cultural do eixo Cannes-Niza que oferece uma diversidade e qualidade de atividades muito similares a Paris, se não superior;

- Vizinhança agradável com grandes espaços verdes entre as empresas;

- Oferta extensa de profissionais de saúde;

- Colégios internacionais com ensino bilingüe.

Porém, existem problemas também em Sophia Antipolis, principalmente porque a região alcançou uma fase de amadurecimento devido a seu rápido crescimento em meados dos anos oitenta, e agora alguns serviços, dos quais o Technopoles, depende estão deficientes:

- Os colégios internacionais não podem aceitar mais alunos;

- As Administrações Públicas estão em Niza, para onde se devem locomover para realizar os trâmites. A Americam Chamber of Commerce está pressionando a Câmara de Comércio de Niza para criar um interlocutor único da Administração Pública em Sophia;

- O custo de vida tem aumentado muito, especialmente, nas áreas próximas em que as empresas se encontram.

O relato da Andersen Consuting observa que a SAEM tem consciência de que para manter os dirigentes, executivos, técnicos e pesquisadores no 
III. Desenvolvimento Industrial Descentralizado

Tecnopoles deve melhorar suas infra-estruturas, pois as empresas já instaladas reagem negativamente a qualquer perda de qualidade de vida. Para monitorar o comportamento do empresários e executivos, a SAEM presta grande atenção nas observações do "Club des dirigeants", o clube que agrupa os principais dirigentes do Tecnopoles.

É importante destacar que em Sophia Antipolis não existe um desenvolvimento interno do Tecnopoles com o spin-off de empresas grandes, o que faz o Technopoles extremamente depende da chegada de empresas externas para continuar a crescer.

Os consultores da Andersen perceberam que a ausência de sinergia entre as empresas aparece como um problema gerado pelos esforços da SAEM em atrair somente empresas estrangeiras cujos centros de decisão estão nos EUA e portanto, estas empresas não têm a liberdade para fomentar oportunidades de colaboração com empresas locais. Por este motivo, a cooperação universidadeempresa está pouco desenvolvida e, por esta razão a SAEM e o Club des dirigeants têm como objetivo prioritário fomentar esta cooperação.

\subsection{Experiência Brasileira}

\subsubsection{Histórico}

Os Pólos Tecnológicos pioneiros foram criado em 1984: o de Campina Grande (Fundação Parque Tecnológico da Paraíba - ParqTec-Pb), o de Florianópolis (Fundação Centro Regional de Tecnologia em Informática-CERTI) e o de São Carlos (Fundação Parque de Alta Tecnologia de São Carlos FPATSC).

Já em 1985 veio a ser criado o de Curitiba, denominado Centro de Integração Tecnológica do Paraná - CITPAR. Em 1986 foi a vez de Campinas, com a Companhia de Desenvolvimento do Pólo de Alta Tecnologia de Campinas - CIATEC -, e também do Rio de Janeiro com o Pólo de Tecnologia do Rio de Janeiro - Riotec. Em 1988, outro Pólo foi criado no Rio de Janeiro: Pólo de Biotecnologia do Rio de Janeiro - Bio-Rio. 
III. Desenvolvimento Industrial Descentralizado

Em 1990, a idéia chegou em Fortaleza com o Parque de Desenvolvimento Tecnológico - PADETEC. No ano de 1992, a cidade paulista de São José dos Campos criou sua Fundação Pólo Tecnológico do Vale do Paraíba FPTVP.

Um dos mais recentes Pólos foi criado em 1996 na cidade de Cascavel, Paraná: Parque Tecnológico Agro-industrial do Oeste - FUNDETEC, onde se destaca a biotecnologia aplicada nas fazendas da região. Interessante, neste projeto paranaense é o pólo ser temático, o que vem ao encontro das novas tendências mundiais de centros especializados e ligados à vocação regional.

\subsubsection{Metas de um Pólo Tecnológico}

Destas experiências brasileiras, pode-se notar que, de forma geral, para consolidar o potencial de desenvolvimento tecnológico em um Pólo, a sua gestão tem sido formalizada para:

- promover a criação e consolidação de empresas de base tecnológica;

- fornecer suporte gerencial e gestão tecnológica às empresas e ao setor acadêmico;

- facilitar a interação sistemática entre empresas e instituições de ensino e pesquisa, para uso de recursos humanos, equipamentos e laboratórios;

- viabilizar o envolvimento de instituições financeiras e governamentais (federal, estadual e municipal).

\subsubsection{Requisitos Mínimos para Implantação}

Algumas das experiência na formatação dos projeto de pólos foram efetivadas sem levar em consideração o potencial regional no nível acadêmico ou de pesquisa, resultando em um esperado fracasso, pela ausência de um indispensável spin-off.

Medeiros \& Atas (1996) verificaram que se deve partir de fatores básicos para que a continuidade do Pólo Tecnológico seja viável. Constataram os pesquisadores que há necessidade de se verificar se a região possui os seguintes requisitos mínimos: 


\section{Desenvolvimento Industrial Descentralizado}

1. existência de pessoas e instituições habilitadas a viabilizar a transformação da pesquisa em inovação tecnológica;

2. empreendedores e lideranças locais que identifiquem a vocação e especialização do pólo tecnológico;

3. linhas de financiamento para projetos tecnológico;

4. orientação das vocações das comunidades científico-tecnológica e empresarial para o mercado;

5. engajamento proativo das instituições locais e governamentais no processo de inovação tecnológica.

\subsubsection{Formatações Viáveis}

Quanto às formas de gestão, Medeiros \& Atas (1996) reconheceram a existência de três formatos para os Pólos Tecnológicos:

1. Pólos de Estrutura Informal: sem gestão formalizada, empresas e instituições estabelecem projetos conjuntos;

2. Pólos de Estrutura Formal: com um órgão gestor voltado para ações estratégicas de desenvolvimento tecnológico;

3. Parque Tecnológico: empreendimento com terrenos, prédios, incubadora e facilidades para tecno-empresas.

\subsubsection{Atividades Básicas do Pólo Tecnológico}

Após estudo de viabilidade, com verificação dos requisitos mínimos, o projeto de implantação que se inicia com a configuração jurídica de um órgão gestor, segundo Medeiros \& Atas (1996), deve colocar à disposição das empresas:

- serviços administrativos: de escritório (processamento de texto, xerox), de comunicação (telex, fax, redes eletrônicas), de informação (banco de dados, livros), de promoção de eventos (encontros entre as empresas e a universidade, entre as próprias empresas);

- serviços empresariais e financeiros: elaboração de planos de negócios e para utilização de financiamentos, consultorias em marketing, produção e qualidade; 
III. Desenvolvimento Industrial Descentralizado

- serviços tecnológicos: contatos entre empresas e universidades, assessoria para transferência de tecnologia;

- serviços de treinamento: empresarial e de pessoal. 
III. Desenvolvimento Industrial Descentralizado

\subsubsection{Pólos com Estruturação Formal}

Em levantamentos realizados junto aos principais pólos tecnológicos brasileiros verificou-se que estes vêm atuando de formas diversas como se pode ver no quadro abaixo onde se tem um visão das formas possíveis encontradas na gestão dos Pólos Tecnológicos com Estruturação Formal.

\begin{tabular}{|c|c|c|}
\hline \multicolumn{3}{|c|}{ Quadro 9} \\
\hline \multicolumn{3}{|c|}{ Estruturação Formal de Pólos Tecnológicos } \\
\hline Pólo & Figura Jurídica & Gestão \\
\hline ParqTec-Pb & Fundação & IES/OF/OP \\
\hline CERTI & Fundação & IES/OF/OE/OP \\
\hline FPATSC & Fundação & IES/OF/OM/OP \\
\hline CITPAR & Sociedade Civil & IES/OE/OP \\
\hline CIATEC & S.A. & IES/OM/Outros \\
\hline Riotec & S.A. & $\mathrm{OE} / \mathrm{OM} / \mathrm{OP}$ \\
\hline Bio-Rio & Fundação & $\mathrm{IES} / \mathrm{OF} / \mathrm{OR} / \mathrm{OE} / \mathrm{OM} / \mathrm{OP}$ \\
\hline PADETEC & Sociedade Civil & $\mathrm{IES} / \mathrm{OF} / \mathrm{OR} / \mathrm{OE}$ \\
\hline FPTVP & Sociedade Civil & IES/OF/OR/OE/OM/OP \\
\hline FUNDETEC & Fundação & IES/OR/OE/OM/OP \\
\hline
\end{tabular}

Fonte: Medeiros \& Atas (1996)

Siglas: IES (Instituição de Ensino Superior), OF (Órgão Federal), OR (Órgão Regional), OE (Órgão Estadual), OM (Órgão Municipal) e OP (Órgão Patronal). 


\subsubsection{Gestão de Pólo Tecnológico}

Nas melhores e mais bem-sucedidas administrações dos Pólos Tecnológicos brasileiros, como as de São Carlos, Florianópolis e Curitiba, as gestões se ativeram em:

- atuar como facilitador da transferência de tecnologia gerada pelo pólo para o setor produtivo;

- estabelecer garantia de maturação das idéias inovadoras;

- vincular os programas das agências de fomento às iniciativas com forte mobilização do setor produtivo;

- motivar a participação das forças produtivas locais;

- atualizar-se com outras instituições correlatas;

- balizar o desenvolvimento do pólo em conjunto com a comunidade de ciência e tecnologia e órgãos de fomento, considerando as diversidades regionais e setoriais;

- disponibilizar a produção tecnológica do pólo para aplicação em entidades governamentais, estatais e autarquias;

- propor novos instrumentos financiadores;

- promover atualização permanente dos participantes;

- sistematizar o registro e transferência de tecnologia;

- identificar lacunas e oportunidades tecnológicas tanto para as empresas quanto para as instituições de ensino e pesquisa e para os profissionais envolvidos no pólo.

\subsubsection{Avaliação dos Serviços e Facilidades Oferecidos pelo Pólos}

a. Uma avaliação dos serviços oferecidos pelos Pólos comparados aos recursos realmente utilizados pelas Empresas, tendo por base 5 entidades (BioRio, ParqTec-Pb, FPATSC, CERTI e CITPAR) e 21 empresas, demonstrou que nos pólos tecnológicos de estrutura formal muitas vezes os serviços e facilidades oferecidos não atendem às necessidades demonstradas pelas empresas, como se pode ver no quadro seguinte. 
III. Desenvolvimento Industrial Descentralizado

\begin{tabular}{|c|c|c|}
\hline \multicolumn{3}{|c|}{ Quadro 10} \\
\hline \multicolumn{3}{|c|}{ Oferecimento e Utilização de Serviços/Facilidades dos Pólos } \\
\hline Serviços e Facilidades & Entidades & Empresas \\
\hline $\begin{array}{l}\text { Auxílio em proposta e identificação de } \\
\text { financiamentos }\end{array}$ & 5 & 4 \\
\hline Marketing e divulgação & 4 & 8 \\
\hline Auxílio no registro de propriedade industrial & 4 & 6 \\
\hline Assessoria jurídica & 4 & 6 \\
\hline Estudos de mercado e consultoria gerencial & 3 & 2 \\
\hline Publicações internas & 2 & 6 \\
\hline Serviços de desenho industrial & 2 & 6 \\
\hline Infra-estrutura administrativa & 5 & 10 \\
\hline Acesso a laboratórios de pesquisa & 5 & 8 \\
\hline Acesso a incentivos fiscais & 5 & 5 \\
\hline Biblioteca & 4 & 4 \\
\hline Auditório & 4 & 5 \\
\hline Busca de informações tecnológicas & 2 & 5 \\
\hline
\end{tabular}

Fonte: Anais do 1o. Seminário Nacional de Pólos e Parque Tecnológicos, Brasília, 1992.

b. Uma outra avaliação foi realizada na Fundação Parque de Alta Tecnologia de São Carlos - FPATSC, que atua em São Carlos através do oferecimento de: 
III. Desenvolvimento Industrial Descentralizado

- Empréstimo de seu endereço e de sua infra-estrutura às empresas nascentes;

- Incubação de pequenas empresas;

- Organização de cursos, seminários e palestras do interesse das empresas de alta tecnologia;

- Promoção da divulgação do Pólo e da Feira de Alta Tecnologia.

Embora tenha sido ofertada uma variedade de serviços aos empreendedores locais, Torkomian fez observações quanto à real importância destes serviços no contexto da gestão empresarial local, obtendo resultados através de uma avaliação da FPATSC pelas empresas e universidades associadas ao pólo, como se pode ver nos quadros seguintes.

\begin{tabular}{|l|c|}
\hline \multicolumn{2}{|c|}{ Quadro 11 } \\
\hline \multicolumn{2}{|c|}{ Avaliação pelas Empresas Associadas da Atuação dos Pólos } \\
\hline Atuação da Gestão do Pólo & Avaliação das Empresas \\
\hline Ajuda porque promove as empresas & $46,7 \%$ \\
\hline Ajuda porque dá confiabilidade e credibilidade & $30,0 \%$ \\
\hline Ajuda devido à infra-estrutura disponível & $10,0 \%$ \\
\hline Poderia ajudar & $06,7 \%$ \\
\hline Ajuda porque promove interação das empresas & $03,3 \%$ \\
\hline Não afeta & $03,3 \%$ \\
\hline
\end{tabular}

Fonte: Torkomian, 1992.

\begin{tabular}{|c|c|}
\hline \multicolumn{2}{|c|}{ Quadro 12 } \\
\hline \multicolumn{2}{|c|}{ Avaliação pelas Universidades da Atuação dos Pólos } \\
\hline Atuação da Gestão do Pólo & Avaliação \\
\hline
\end{tabular}


III. Desenvolvimento Industrial Descentralizado

\begin{tabular}{|l|c|}
\hline Ajuda porque promove a Universidade & $57,8 \%$ \\
\hline Não afeta & $11,1 \%$ \\
\hline Ajuda porque facilita a captação de recursos & $8,9 \%$ \\
\hline Ajuda porque melhora a imagem & $6,7 \%$ \\
\hline Ajuda porque aproxima as empresas & $4,4 \%$ \\
\hline Ajuda porque aumenta a responsabilidade & $4,4 \%$ \\
\hline Ajuda porque promove o desenvolvimento & $2,2 \%$ \\
\hline Poderia ajudar & $2,2 \%$ \\
\hline Não sabe & $2,2 \%$ \\
\hline
\end{tabular}

Fonte: Torkomian, 1992.

Com base nas experiências de implantação e na avaliação dos serviços e facilidades oferecidos pelo pólos tecnológicos, pode-se ver que a integração entre empresas e a comunidade acadêmica depende de uma atmosfera regional que favoreça a capacitação da localidade para a inovação tecnológica.

Este fenômeno entretanto não se caracteriza apenas como resultado de uma articulação entre potenciais parceiros de uma comunidade interessada em uma dinamização de sua base produtiva através da incorporação de empreendimentos de base tecnológica, há uma complexidade maior, o que faz com que um projeto que tenha por objetivo o desenvolvimento local com base em empreendimentos de base tecnológica devam considerar o território regional como espaço produtivo pleno de tecnologia.

Uma região onde a vida tem sua plenitude através da tecnologia, onde se permite à sociedade humana a igualdade de oportunidades e participação democrática no desenvolvimento de suas comunidades locais, um lugar que se poderia chamar de "Tecnópolis". 


\section{As Tecnópolises}

"Cidades e regiões em todo o planeta estão sendo profundamente modificadas em suas estruturas e condicionadas em seus crescimentos econômicos pela ação combinada de três importantes processos históricos: revolução tecnológica, formação da economia global e a emergência de uma forma informacional de produção e gerenciamento", dizem Castells \& Hall (1994). E, como resposta natural a este desafio no mundo em processo de globalização, surgem as Tecnópolises, sofisticadas áreas urbanas, envolvidas por regiões competentes para o desenvolvimento da indústria baseada em alta tecnologia.

Este peculiar processo, determinado pela sinergia entre agentes de uma região, vem gerando o material de sustentação da evolução e crescimento da "Nova Economia" e redefinindo condições e processos do desenvolvimento local de centros urbanos até então vistos apenas como pólos tecnológicos.

Podem ser especialmente criadas, ou forjadas a partir de um amálgama de caraterísticas essenciais de uma determinada região, “as Tecnópolises sepultam a imagem da economia industrial do século 19, familiar aos livros escolares: a mina de carvão e sua vizinha fundição, expelindo fumaça negra para o céu e iluminando a noite com seu tétrico clarão vermelho na visão" afirmam Castells \& Hall (1994).

Comprometidas com a questão ambiental, trazendo em seu bojo a esperança de um verdadeiro desenvolvimento sustentável ${ }^{1}$, as Tecnópolises são a imagem utópica da "Nova Economia" que apenas está começando a ser impressa em nossa consciência: arquitetura com equilíbrio, edifícios envolvidos por um ar leve e agradável em meio a impecáveis paisagens, onde pessoas trabalham felizes em ambientes puros e saudáveis, com o urbanismo e a infra-estrutura dando suporte a uma atmosfera propícia a troca de conhecimento e estimulando a criatividade.

Cenas cinematográficas como essas são divulgadas e oferecidas em muitas áreas urbanas dinâmicas do mundo globalizado. Mas, talvez, a realidade da economia informacional não seja realmente a de nos levar a estes enlevos, porque também "a construção de pelo menos um cidade tecnológica é, economicamente 
III. Desenvolvimento Industrial Descentralizado

falando, uma questão de segurança nacional" consideraram os analistas da revista Neesweek (November 9, 1998).

\subsection{Projetos de Tecnópolis no Mundo}

Além dos EUA, com centros tecnológicos como Austin e Boston e o mitológico Vale do Silício, muitos outros países ${ }^{2}$ apostam nesta nova onda desenvolvimentista a partir de cidades como pólos tecnológicos. Assim, têm-se, entre várias outras importantes iniciativas: Inglaterra, com Cambridge; Irlanda, com Dublin; Finlândia, com Helsinque; Índia, com Bangalore; França, com Sophia Antipolis; Japão, com Tsukuba; Austrália, com Adelaide e Israel, com Tel Aviv.

O projeto de implantação ou desenvolvimento de uma Tecnópolis pode seguir caminhos diversos, sendo na maior parte das experiências processos de economia urbana planejados.

Para que se consolide é essencial, como foi na região californiana do Silicon Valley, o centro mundial da inovação de alta tecnologia, que "executivos, governantes, educadores e lideranças comunitárias formem uma rede de articulações com participação de empreendedores com mentalidade cívica em colaboração com a comunidade", de acordo com constatações de pesquisas de Henton, Melville \& Walesh (1997).

Reportam-se nas Tecnópolises, parcerias em uma matriz de colaborações, no nível local e regional, alinhadas para trabalhar com as quatro forças da "Nova Economia": globalização, tecnologia da informação, mercados emergentes e reorganização da administração governamental, representada, principalmente, pela privatização de serviços públicos.

Inseridas neste contexto, as Tecnópolises também contêm importantes instituições dos tipos pública-privada (as chamadas empresas de economia mista) e as do tipo sem fins-lucrativos, tais como institutos de pesquisa, os quais são especificamente implantados nas Tecnópolises para ajudar na geração de nova informação e novo conhecimento, materiais básicos para a economia informacional. 
III. Desenvolvimento Industrial Descentralizado

É importante compreender o conceito de desenvolvimento tecnológico, a principal missão a ser empreendida para fortalecimento da Tecnópolis, como a aplicação de tecnologia, técnicas, informações, produtos e serviços que visem atender às necessidades de inovação e desenvolvimento da sociedade como um todo.

Tem-se, então, que o desenvolvimento tecnológico de uma cidade ou região, entre outros "fatores vocacionais" como: infra-estrutura, telecomunicações e mão-de-obra qualificada, é determinante na atratividade local dos agentes econômicos para novos investimentos. Sendo assim, é de interesse público, além de empresarial, alcançar uma qualificação adequada em desenvolvimento tecnológico tendo em vista os resultados econômicos regionais de interesse coletivo que podem ser obtidos.

Porém o processo de urbanização que acompanha a transformação no desenvolvimento tecnológico poderá estar criando cidades que, se por um lado oferecem oportunidades para atividade econômica global, por outro lado é atacada por sérios problemas econômicos e sociais. As sociedades em redes baseadas em informações e tecnologias de comunicação dão origem a um miríade de outros fluxos sócio-econômicos complexos.

Surgem, então, intensas interações dentro de espaços urbanos regionais que estarão coexistindo com fluxos de informação e comunicação como é o caso em Bangalore, que está apresentando uma crescente tensão. Esta cidade, na região sul da Índia, é um pólo de desenvolvimento de software amplamente reconhecido no mundo digital. Entretanto, junto com o sucesso trazido pela economia informacional, a região de Bangalore vem sendo atacada por problemas de deficiências crônicas, como pobreza crescente e desigualdade de renda, ao lado de um mercado imobiliário caótico, de acordo com levantamentos e estudos realizados por Sahay \& Madon (1999).

Mas, excluindo-se tais problemas de natureza sócio-econômica, em síntese o desenvolvimento tecnológico empreendido em uma Tecnópolis visa capacitar a economia regional tendo por objetivos:

- ampliar a base de postos de serviços qualificados, melhor remunerados; 


\section{Desenvolvimento Industrial Descentralizado}

- melhorar a competitividade pública e empresarial;

- aumentar a produtividade pública e empresarial.

Deve-se lembrar, ainda, que tais metas do desenvolvimento tecnológico dificilmente serão alcançados com ações isoladas. É essencial, para uma Tecnópolis ter clara em sua meta uma estratégia de política tecnológica para construir uma inter-relação de parcerias regionais, aproximando oferta e demanda de tecnologia, técnicas, informações, produtos e serviços.

Obtém-se essa construção na formatação pela Tecnópolis de uma gestão tecnológica compartilhada pela sociedade local e regional que conduza a criação de um complexo de atividades em um determinado espaço centralizador, sendo esta estrutura operacional seu pólo tecnológico, uma espécie de coração e mente de uma Tecnópolis.

Os efeitos sinergéticos se potencializam dessa forma e esta organicidade, refletida na consolidação dos investimentos, nos intercâmbios científicos entre especialistas e pesquisadores de diferentes áreas, na adequação dos projetos às necessidades locais e regionais, nas facilidades do acesso das empresas a profissionais e serviços oferecidos, vem facilitar as reivindicações dos indispensáveis apoios institucionais, tendo resultados otimizados pelas proximidades físicas dos agentes que devem integrar a gestão do pólo tecnológico.

Estes esforços, em cooperação e colaboração, entre empresas e centros do conhecimento, asseguram pontos focais para as idéias tecnológicas, servindo, no futuro, para atender de forma competitiva as necessidades de inovação e desenvolvimento da sociedade regional de forma ampla.

Deve-se observar que dentro desta concepção de gestão tecnológica é fundamental o papel inter-governamental pró-ativo em favor desta integração, pois a condução do processo envolve a comunidade regional em muitos aspectos políticos que extrapolam a natureza partidária de uma autoridade governamental local ou regional.

\subsection{Programa de Tecnópolis no Japão}




\section{Desenvolvimento Industrial Descentralizado}

Diferente dos outros programas que visam a implantação das Tecnópolises no mundo industrial, este programa do governo japonês, desenvolvido pelo Ministério da Indústria e do Comércio Internacional do Japão, é um plano de abrangência nacional que visa dar condições a várias regiões, algumas delas sem nenhuma vocação para o desenvolvimento de projetos de alta tecnologia.

O plano consistiu-se de múltiplas estratégias como: criar centros de pesquisas tecnológicas, públicos e privados, melhoramentos em laboratórios de universidades locais, estímulo a novas tecnologias, estabelecimento de centros tecnológicos, parcerias e financiamentos a projetos de pesquisa e desenvolvimento.

O objetivo era transferir a geração de negócios que envolvem produtos altamente tecnológicos dos centros de negócios tradicionais, como Tóquio, Nagoya e Osaka para as regiões periféricas do Japão, observaram Castells \& Hall.

Esta preocupação em desconcentrar a economia japonesa se devia à constatação de que a Grande Tóquio e Osaka vinha retendo em suas regiões todas as vantagens advindas com o crescimento da participação japonesa na economia mundial, fato que vinha ocorrendo desde a década de 50 e que tinha se acentuado com o boom econômico da década de 80 .

Castells \& Hall levantaram que 80 por cento dos laboratórios das grandes companhias tecnológicas, 70 por cento dos cientistas e 60 por cento dos pesquisadores universitários estavam concentrados na Grande Tóquio e Osaka. Além disso, esta macro área detinha 50 por cento das companhias de pesquisa e desenvolvimento, 65 por cento de todos os computadores e 61 por cento dos empregos em tecnologia de informação.

\subsubsection{Tecnópolis e Desenvolvimento Regional no Japão}

Alcançar um equilíbrio no desenvolvimento regional, através de uma igualdade nas oportunidades oferecidas pelo mundo globalizado foi o grande objetivo do programa japonês das Tecnópolises, reduzindo a predominância até então observada na capital Tóquio e sua região metropolitana. 
III. Desenvolvimento Industrial Descentralizado

A meta de atingir uma posição internacional de destaque e liderança no desenvolvimento de inovação tecnológica, portanto, não era exclusivamente a razão do esforço nacional japonês, havia por trás desse plano a busca por equilíbrio geográfico do crescimento das atividades econômicas.

O Japão já vinha, desde a década de 60, tentando minimizar os problemas decorrentes da concentração industrial na Grande Tóquio, em 1962 foram escolhidos 16 pólos de desenvolvimento, em 1969 um plano de escoamento da produção industrial foi fundamentado na melhoria da rede ferroviária japonesa e com grandes projetos industriais.

Mas foi na década de 70 que, pela primeira vez, um conjunto de ações integradas foi implementado pelo governo criando uma rede de transporte expresso, integrando ferrovias e rodovias, junto com uma rede de telecomunicações e novas cidades voltadas para a economia informacional. A estas ações ainda foram acrescentadas outras que tinham por objetivo específico melhorar as condições e qualidade de vida de regiões deterioradas do Japão.

Embora estes planos não tenham tido um êxito completo, especialmente por uma seqüência de crises governamentais japonesas e na economia internacional, eles deram suporte ao plano das Tecnópolises que viria a seguir.

Castells \& Hall identificaram como início da formulação do programa nacional de Tecnópolis no Japão o encontro entre pesquisadores japoneses com um representante da Associação Americana da Industria Eletrônica, que trouxe a idéia de inovação tecnológica como um processo viável de planejamento regional a partir da experiência bem-sucedida do Silicon Valley.

Nesta ocasião uma série de razões para justificar o plano foram identificadas, ficando os japoneses de discutir com as autoridades governamentais a possibilidade de implantação em Tóquio e região metropolitana ou em Tsukuba Science City, um pólo tecnológico de reconhecida competência.

Porém os técnicos e executivos do governo concluíram que as cidades japonesas não ofereciam condições que pudessem atender as exigências para serem consideradas Tecnópolises viáveis para desenvolvimento de produtos de alta tecnologia inovadores. Duas razões foram apontadas: a primeira que as 
III. Desenvolvimento Industrial Descentralizado indústrias tecnológicas ali encontradas eram exageradamente competitivas e imitativas e, a segunda, que seus pesquisadores eram demasiadamente acadêmicos.

Em 1980, o MITI apresentou o plano - que era em sua essência econômico, elaborado com a participação de representantes da esfera governamental, do meio acadêmico, das indústrias, dos consumidores e dos sindicatos de trabalhadores, todos compartilhando a mesma visão - sobre o que seria a Tecnópolis japonesa:

"Um local pleno de tecnologia, que efetivamente combina o setor industrial de eletrônicos, equipamentos e outros produtos de avançada tecnologia, com o setor acadêmico, tendo um ambiente favorável para produzir e viver com qualidade de vida".

Este conceito visava a promoção do desenvolvimento das regiões japonesas, criando uma nova cultura regional conduzido por um progresso industrial e acadêmico, diferente da idéia convencional de desenvolvimento regional centrado na potencialização do uso do solo através de melhoramentos da infra-estrutura urbana.

Observaram Castells \& Hall um interessante mix de idéias sobre desenvolvimento regional que foi se aperfeiçoando, misturando elementos de Silicon Valley, com a concepção de Tsusuka, resgatando idéias das cidades jardins inglesas, já anteriormente projetadas no Japão por urbanistas de Londres, a visão de centros de pesquisa universitários, centros de tecnologia, parcerias para consórcios de pesquisa e desenvolvimento, a formação de fundos para capital de risco, centros de convenções e negócios internacionais e novos condomínios residenciais.

Uma característica desta estratégia foi abandonar a idéia de desenvolvimento regional como implantação de serviços públicos, investindo o governo japonês em favor de uma infra-estrutura soft e em treinamento de pessoas, novas tecnologias, serviços de informação e comunicação, e em capital de risco.

Em um macro objetivo, conforme observado por Castells \& Hall, havia também o esforço do governo do Japão em reconduzir muitos trabalhadores 
III. Desenvolvimento Industrial Descentralizado

que haviam vindo das áreas rurais e regiões periféricas através de estímulos aos conglomerados nacionais para implantação de fábricas dentro do território japonês, o que não vinha ocorrendo, com as empresas investindo em outros países, como Taiwan e Malásia.

Desta estratégia fazia parte também investimentos federais para o desenvolvimento social destas regiões mais afastadas de Tóquio, com melhoria da educação, qualidade de vida e da produção agrícola regional, provocando uma mudança de visão sobre a vida no campo, que passou a ser atraente fazendo com que muitos japoneses voltassem a suas cidades de nascimento deixando a congestionada metrópole.

\subsubsection{Concepção do Programa}

Um conjunto de leis que determinava um cronograma básico onde ficou estabelecido que em 1984 estariam escolhidos os locais onde seriam construídas as infra-estruturas, que deveriam estar concluídas em 1990, ficando o ano de 2000 como a data limite para que todas estivessem funcionando, foi aprovado em 1983 tendo a ambiciosa meta de implantar um verdadeiro "TechnoArquipelago" no século XXI em território japonês.

A escolha dos locais onde seriam feitos os investimentos viria a apresentar uma série de exigências:

1. uma área total de no máximo $1300 \mathrm{~km} 2$, em um ou mais locais;

2. existência de empreendimento com potencial para desenvolvimento de alta tecnologia;

3. áreas industriais viáveis facilmente, bem como áreas residenciais e disponibilidade de água;

4. existência de uma cidade mãe com pelo menos 150.000 habitantes, que seria considerada a capital da Tecnópolis;

5. existência de uma universidade com educação ou pesquisas em alta tecnologia; 


\section{Desenvolvimento Industrial Descentralizado}

6. acesso a transporte de alta velocidade, para viagens rápidas para Tóquio, Nagóia ou Osaka.

É importante destacar que as Tecnópolises não seriam unicamente centros produtores de alta tecnologia, mas também locais onde haveriam pesquisas e desenvolvimento de novos produtos, os quais deveriam estar integrados aos parques industriais locais já existentes nas regiões.

$\mathrm{Na}$ verdade, segundo Castells \& Hall, o MICI não tinha uma idéia precisa de como integrar indústrias locais aos setores escolhidos como estratégicos, mas esta integração daria suporte à implantação das Tecnópolises.

Para superar esta dificuldade, foram dadas condições para que as empresas participassem de programas de pesquisas e desenvolvimento nos setores estratégicos do programa através de estímulos para a mudança de localização das industrias existentes nas congestionadas áreas metropolitanas japonesas.

Além disso, também houve incentivos para que as indústrias localizadas nas regiões escolhidas para integrarem o plano das Tecnópolises se qualificassem para estes novos setores. Dessa forma, pretendia-se que o programa encontrasse ressonância não apenas em grandes empresas, mas também entre as pequenas e médias empresas industriais locais, criando uma revolução tecnológica na base industrial japonesa.

Investimentos em pesquisa e desenvolvimento em empresas já existentes, dando ênfase em capacitação eletrônica e mecatrônica, foram privilegiados inicialmente. Após isto, técnicas inovadoras deveriam ser implantadas estimulando a criação de novas indústrias regionais.

$\mathrm{O}$ argumento era que pesquisa básica deveria ser desenvolvida nas indústrias locais, deixando para o pólo tecnológico da cidade mãe o acesso às informações científicas, acesso às administrações governamentais e coordenações empresariais e amenidades metropolitanas.

Castells \& Hall observaram um consenso no modelo a ser seguido para determinar o local de uma Tecnópolis: as localidades interessadas deveriam competir e oferecer vantagens para ser escolhida como sede do investimento, 
III. Desenvolvimento Industrial Descentralizado

sendo um fator predominante os incentivos oferecidos pela comunidade da província para programas de pesquisa e desenvolvimento.

O processo de escolha seria levado de baixo para cima, com as prefeituras oferecendo suas vantagens de forma que a escolhida viesse a participar ativamente do desenvolvimento do projeto, ficando o ministério responsável pelo apoio e assistência técnica, além de providenciar recursos financeiros através do Banco de Desenvolvimento do Japão, esta era a posição do MICI.

Segundo Castells \& Hall, a mobilização empresarial, política e comunitária das regiões foram além da esperada, participando 47 prefeituras, e destas 40 foram pré-selecionadas, provocando uma elevação do número previsto de Tecnópolis que passou da previsão de 3 cidades para 19 escolhidas. Destaca-se que após esta escolha, mais 7 foram chamadas, totalizando 26 ao final de $1990^{3}$.

Também é importante lembrar que até está data nem todas atendiam os requisitos mínimos estipulados pelas leis que criaram o programa, porém um conjunto de pressões realizadas por políticos, empresários e líderes universitários e comunitários acabou por minimizar os critérios para a escolha das cidades, o que veio criar uma certa tensão entre os técnicos do MICI e políticos japoneses.

Um outro aspecto que explica a razão desta disputa pela participação no programa de Tecnópolis seriam os altos investimentos realizados pelo governo japonês.

E, embora fosse prevista uma participação financeira efetiva das prefeituras no programa, isto não ocorreu devido à crise que vinha e ainda vem infringindo às localidades no Japão uma grande déficit orçamentário na administração das contas públicas municipais, dessa maneira os custos de onze Tecnópolises, até 1990, em infra-estrutura foram cobertos exclusivamente pelo Ministério da Construção do Japão alcançando uma média de 200 milhões de dólares americanos em cada uma delas.

\subsubsection{Implantação do Programa}

As Tecnópolises, embora significativamente diferentes entre si, tinham sempre em comum, geralmente localizadas no núcleo da região, um complexo voltado para pesquisa, como era intenção do MICI. 


\section{Desenvolvimento Industrial Descentralizado}

Muitos destes centros eram implantados através de melhorias de instalações e laboratórios já existentes nas regiões, sendo que alguns destes foram especialmente edificados para dar suporte às pesquisas científicas e tecnológicas que os empreendimentos iriam exigir para atingir as metas de inovação propostas pelo governo japonês.

Através da forma de implantação, Castells \& Hall puderam obter uma classificação em três modelos de Tecnópolis:

1. Defasada - em que o desenvolvimento industrial inovador não vinha acontecendo por uma tradicional restrição gerencial à incorporação de novas tecnologias, o que provocava uma defasagem tecnológica e que dificultaria a implantação do programa das Tecnópolises, o que poderia inviabilizar o surgimento de uma base industrial secundária, fator fundamental para um dos objetivos do programa que era a inovação;

2. Satélite - cujo parque industrial com potencial de desenvolvimento de alta tecnologia vinha provocando uma significativa atração de investidores que encontraram nos setores inovadores potencial para suas aplicações;

3. Transformada - áreas em que as indústrias tradicionais que estavam incorporando o espírito da inovação em suas operações e investiam concretamente em pesquisa e desenvolvimento, obtendo uma transformação nos processos e produtos, que acabaram por caracterizar as regiões em local de aplicação de alta tecnologia intensiva e de produtos inovadores.

De acordo com a Japan External Trade Organization - Jetro -, agência do MITI, as 38 Tecnópolises foram criadas pelo governo japonês com base na Brain Location Law, de 1988, com objetivo de promover a relocação específica de empreendimentos com potencial para contribuição no aumento do nível das indústrias locais, e na Technopolis Law, de 1983, para promoção do desenvolvimento regional através da concentração de indústrias de alta tecnologia.

A diferença entre as duas leis de incentivo à inovação tecnológica está em que a Technopolis Law é ligada às indústrias de alta tecnologia, centrada em 
III. Desenvolvimento Industrial Descentralizado

torno da industrialização, e a Brain Location Law é ligada às divisões das indústrias voltadas para a pesquisa e processamento de dados, e também aos serviços industriais que apoiam as indústrias de alta tecnologia como serviços de informação e design.

Em comum ambas as leis fomentavam indústrias com construção de fábricas, com seus galpões e escritórios; a criação de organizações para apoio ao desenvolvimento industrial; e empreendimentos residenciais.

Com estas leis ${ }^{4}$ pretendia o governo japonês estimular a concentração de indústrias de alta tecnologia em áreas previamente aprovadas para obter uma qualificação regional, através de investimentos federais e locais, que permitisse um aumento do nível tecnológico das pequenas e médias empresas locais através de um entrelaçamento entre companhias e um mix entre indústria, governo e universidade.

Dessa maneira, classificadas ${ }^{5}$ de acordo com estas duas leis, estas regiões consideradas como Tecnópolises eram as seguintes:

\section{Distrito de Hokkaido}

\begin{tabular}{|l|c|c|c|}
\hline Tecnópolis & Área $(\mathbf{k m 2})$ & População & Lei \\
\hline Asahikawa & 748 & 360.000 & Brain Location \\
\hline Do-o & 1.307 & 320.000 & Technopolis \\
\hline Hakodate & 961 & 370.000 & Technopolis \\
\hline
\end{tabular}

2. Distrito de Tohoku

\begin{tabular}{|l|c|c|c|}
\hline Tecnópolis & Área(km2) & População & Lei \\
\hline Aomori & 1.542 & 610.000 & Technopolis \\
\hline Hachinohe & 806 & 380.000 & Brain Location \\
\hline Morioka & 739 & 350.000 & Brain Location \\
\hline Kitakamigawa & 1.462 & 270.000 & Technopolis \\
\hline Miyagi & 800 & 980.000 & Technopolis \\
\hline Akita & 905 & 330.000 & Technopolis \\
\hline Yamagata & 1.280 & 510.000 & $\begin{array}{c}\text { Technopolis Brain } \\
\text { Location }\end{array}$ \\
\hline Koriyama & 1.152 & 452.250 & $\begin{array}{c}\text { Technopolis Brain } \\
\text { Location }\end{array}$ \\
\hline
\end{tabular}


3. Distrito de Kanto

\begin{tabular}{|l|c|c|c|}
\hline Tecnópolis & Área(km2) & População & Lei \\
\hline Mito-Hitachi & 790 & 760.000 & Brain Location \\
\hline Utsunomiya & 703 & 630.000 & $\begin{array}{c}\text { Technopolis Brain } \\
\text { Location }\end{array}$ \\
\hline Gumma & 783 & 1.160 .000 & Brain Location \\
\hline Shinanogawa & 1.526 & 640.000 & Technopolis \\
\hline Kofu & 890 & 450.000 & $\begin{array}{c}\text { Technopolis Brain } \\
\text { Location }\end{array}$ \\
\hline Asama & 1.038 & 350.000 & Technopolis \\
\hline Hamamatsu & 656 & 710.000 & $\begin{array}{c}\text { Technopolis Brain } \\
\text { Location }\end{array}$ \\
\hline
\end{tabular}

4. Distrito de Chubu

\begin{tabular}{|l|c|c|c|}
\hline Tecnópolis & Área(km2) & População & Lei \\
\hline Toyama & 727 & 600.000 & $\begin{array}{c}\text { Technopolis Brain } \\
\text { Location }\end{array}$ \\
\hline Ishikawa & 1.056 & 750.000 & Brain Location \\
\hline Gifu & 745 & 1.020 .000 & Brain Location \\
\hline
\end{tabular}

5. Distrito de Kinki

\begin{tabular}{|l|c|c|c|}
\hline Tecnópolis & Área(km2) & População & Lei \\
\hline Nishiharima & 1.360 & 740.000 & Technopolis \\
\hline Wakayama & 802 & 690.000 & Brain Location \\
\hline
\end{tabular}

6. Distrito de Chugoku

\begin{tabular}{|l|c|c|l|}
\hline Tecnópolis & Área(km2) & População & Designação \\
\hline Tottori & 779 & 270.000 & Brain Location \\
\hline Okayama & 1.454 & 720.000 & $\begin{array}{l}\text { Technopolis Brain } \\
\text { Location }\end{array}$ \\
\hline Hiroshima-Chuo & 681 & 390.000 & $\begin{array}{l}\text { Technopolis Brain } \\
\text { Location }\end{array}$ \\
\hline Yamagushi & 1.253 & 560.000 & $\begin{array}{l}\text { Technopolis Brain } \\
\text { Location }\end{array}$ \\
\hline
\end{tabular}


III. Desenvolvimento Industrial Descentralizado

7. Distrito de Shikoku

\begin{tabular}{|l|c|c|c|}
\hline Tecnópolis & Área(km2) & População & Lei \\
\hline Tokushima & 787 & 580.000 & Brain Location \\
\hline Kagawa & 614 & 650.000 & $\begin{array}{c}\text { Technopolis Brain } \\
\text { Location }\end{array}$ \\
\hline Ehime & 126 & 850.000 & Technopolis \\
\hline
\end{tabular}

\section{Distrito de Kyushu-Okinawa}

\begin{tabular}{|l|c|c|c|}
\hline Tecnópolis & Área(km2) & População & Lei \\
\hline Kitayushu & 670 & 1.300 .000 & Brain Location \\
\hline Kurume-Tosu & 308 & 370.000 & Technopolis \\
\hline Nagasaki & 774 & 540.000 & $\begin{array}{c}\text { Technopolis Brain } \\
\text { Location }\end{array}$ \\
\hline Kumamoto & 989 & 870.000 & Technopolis \\
\hline Oita & 2.293 & 820.000 & $\begin{array}{c}\text { Technopolis Brain } \\
\text { Location }\end{array}$ \\
\hline Miyasaki & 870 & 410.000 & $\begin{array}{c}\text { Technopolis Brain } \\
\text { Location }\end{array}$ \\
\hline Kagoshima & 1.320 & 770.000 & $\begin{array}{c}\text { Technopolis Brain } \\
\text { Location }\end{array}$ \\
\hline Okinawa & 704 & 1.050 .000 & Brain Location \\
\hline
\end{tabular}

Os segmentos industriais e campo de pesquisa nestas regiões deveriam ser os seguintes:

\section{Distrito de Hokkaido}

\begin{tabular}{|l|c|}
\hline Tecnópolis & Segmento Industrial e de Pesquisa \\
\hline Asahikawa & $\begin{array}{c}\text { Produtos que interferem no meio ambiente: construção, infra- } \\
\text { estrutura, reciclagem, hospitalar }\end{array}$ \\
\hline Do-o & Mecatrônicos, novos materiais, biotecnologia \\
\hline Hakodate & $\begin{array}{c}\text { Mecatrônicos e eletrônicos, novos materiais, biotecnologia e } \\
\text { alimentos processados }\end{array}$ \\
\hline
\end{tabular}


2. Distrito de Tohoku

\begin{tabular}{|l|c|}
\hline Tecnópolis & $\begin{array}{c}\text { Segmento Industrial e de Pesquisa } \\
\text { Aomori }\end{array}$ \\
\hline Hachinohe & $\begin{array}{c}\text { Software, design, processamento de dados, maquinaria } \\
\text { elétrica, alimentos processados }\end{array}$ \\
\hline Morioka & $\begin{array}{c}\text { Sofware, design, serviços de informação, desenho industrial, } \\
\text { agências de propaganda }\end{array}$ \\
\hline Kitakamigawa & Mecatrônicos, eletrônicos, novos materiais, biotecnologia \\
\hline Miyagi & $\begin{array}{c}\text { Maquinaria elétrica, alimento processado, meio ambiente, } \\
\text { comunicação de dados, biotecnologia }\end{array}$ \\
\hline Akita & $\begin{array}{c}\text { Mecatrônicos, eletrônicos, novos materiais, biotecnologia, } \\
\text { energia, serviços de apoio industrial }\end{array}$ \\
\hline Yamagata & $\begin{array}{c}\text { Mecatrônicos, eletrônicos, biotecnologia, moda, meio } \\
\text { ambiente, design, sofware, ciências naturais }\end{array}$ \\
\hline Koriyama & $\begin{array}{c}\text { Microeletrônicos, tecnologia dos novos materiais, } \\
\text { biotecnologia industrial, novos produtos industriais }\end{array}$ \\
\hline
\end{tabular}

\section{Distrito de Kanto}

\begin{tabular}{|l|c|}
\hline Tecnópolis & $\begin{array}{c}\text { Segmento Industrial e de Pesquisa } \\
\text { Mito-Hitachi }\end{array}$ \\
\hline Utsunomiya & $\begin{array}{c}\text { Sofware, serviços de processamento de dados, design, ciências } \\
\text { naturais, serviços de informação }\end{array}$ \\
\hline Gumma & $\begin{array}{c}\text { Mecatrônicos, eletrônicos, biotecnologia, química fina, novos } \\
\text { materiais, sofware } \\
\text { ambiente, design, informação e comunicação }\end{array}$ \\
\hline Shinanogawa meio & $\begin{array}{c}\text { Mecatrônica avançada, tecnologia laser, maquinaria de } \\
\text { precisão, embalagens, produtos do dia-a-dia }\end{array}$ \\
\hline Kofu & $\begin{array}{c}\text { Sistemas com tecnologia ótica, mecatrônica avançada, novos } \\
\text { materiais, biotecnologia, design }\end{array}$ \\
\hline Asama & Mecatrônica avançada, biotecnologia, multimídia \\
\hline Hamamatsu & Tecnologia ótica, mecatrônica avançada, software \\
\hline
\end{tabular}

\section{Distrito de Chubu}

\begin{tabular}{|l|c|}
\hline Tecnópolis & Segmento Industrial e de Pesquisa \\
\hline Toyama & $\begin{array}{c}\text { Mecatrônicos, novos materiais, biotecnologia, sofware, } \\
\text { processamento de dados, design, serviços de informação }\end{array}$ \\
\hline Ishikawa & Software, design mecânico, design, máquinas, têxteis \\
\hline Gifu & $\begin{array}{c}\text { Tecnologia para realidade virtual, sofware, informação } \\
\text { utilizando multimídia e tecnologia de comunicações }\end{array}$ \\
\hline
\end{tabular}




\section{Distrito de Kinki}

\begin{tabular}{|l|c|}
\hline Tecnópolis & Segmento Industrial e de Pesquisa \\
\hline Nishiharima & $\begin{array}{c}\text { Maquinaria para alta tecnologia (equipamentos mecatrônicos, } \\
\text { óptico-eletrônicos), médicos e farmacêuticos }\end{array}$ \\
\hline Wakayama & Produtos do dia-a-dia da vida moderna, maquinarias \\
\hline
\end{tabular}

\section{Distrito de Chugoku}

\begin{tabular}{|l|c|}
\hline Tecnópolis & Segmento Industrial e de Pesquisa \\
\hline Tottori & $\begin{array}{c}\text { Maquinaria elétrica, alimentos e outros produtos industriais } \\
\text { usando os recursos naturais locais }\end{array}$ \\
\hline Okayama & $\begin{array}{c}\text { Embalagens e usinagem, biotecnologia, sofware, design, } \\
\text { design de máquinas }\end{array}$ \\
\hline Hiroshima-Chuo & $\begin{array}{c}\text { Mecatrônicos, eletrônicos, novos materiais, biotecnologia, } \\
\text { sofware, novas fontes de energias, design de máquinas }\end{array}$ \\
\hline Yamagushi & $\begin{array}{c}\text { Novos materiais de componentes, bioindústria, química fina, } \\
\text { mecatrônicos, sofware, energia, produtos marinhos }\end{array}$ \\
\hline
\end{tabular}

\section{Distrito de Shikoku}

\begin{tabular}{|l|c|}
\hline Tecnópolis & Segmento Industrial e de Pesquisa \\
\hline Tokushima & $\begin{array}{c}\text { Produtos para redes informatizadas, habitação, meio ambiente, } \\
\text { saúde e medicina }\end{array}$ \\
\hline Kagawa & Mecatrônicos, biotecnologia, sofware, novos materiais \\
\hline Ehime & Sistemas avançados, biotecnologia, alta tecnologia urbana \\
\hline
\end{tabular}

\section{Distrito de Kyushu-Okinawa}

\begin{tabular}{|l|c|}
\hline Tecnópolis & Segmento Industrial e de Pesquisa \\
\hline Kitayushu & $\begin{array}{c}\text { Informação e multimídia, reciclagem e energia, produtos para } \\
\text { meio ambiente, saúde e medicina, aeroespaciais, embalagem }\end{array}$ \\
\hline Kurume-Tosu & $\begin{array}{c}\text { Mecatrônicos, química fina, moda, novos campos da alta } \\
\text { tecnologia em biotecnologia e novos materiais }\end{array}$ \\
\hline Nagasaki & $\begin{array}{c}\text { Maquinaria para pequenas e médias metalúrgicas, indústrias } \\
\text { ligadas ao oceano e meio ambiente, biotecnologia }\end{array}$ \\
\hline Kumamoto & $\begin{array}{c}\text { Maquinaria, biotecnologia, ferramentas eletrônicas, sistemas de } \\
\text { informação }\end{array}$ \\
\hline Oita & $\begin{array}{c}\text { Eletrônicos, mecatrônicos, biotecnologia, automóveis, medicina } \\
\text { e saufware, processamento de dados }\end{array}$ \\
\hline Miyasaki & $\begin{array}{c}\text { Biotecnologia, eletrônicos, mecatrônicos, serviços urbanos, } \\
\text { software, processamento de dados, serviços de informação }\end{array}$ \\
\hline Kagoshima & Alimentos, novos materiais, eletrônicos, multimídia, software \\
\hline Okinawa & $\begin{array}{c}\text { Software, processamento de dados, serviços de informação e } \\
\text { distribuição, produtos originários de recursos sub-tropicais }\end{array}$ \\
\hline
\end{tabular}


III. Desenvolvimento Industrial Descentralizado

No quadro ${ }^{6}$ seguinte estão características de estruturas implantadas e disponíveis para pesquisa em algumas das regiões do programa Tecnópolis em análise.

\begin{tabular}{|c|c|}
\hline & Quadro 13 \\
\hline \multicolumn{2}{|r|}{ Estruturas para Pesquisa nas Tecnópolises do Japão } \\
\hline Do-o & Parque empresarial e de pesquisa Eniwa \\
\hline Hakodate & $\begin{array}{l}\text { Centro de pesquisa marinha regional integrado, centro de } \\
\text { desenvolvimento urbano }\end{array}$ \\
\hline Aomori & $\begin{array}{l}\text { Laboratório de pesquisa tecnológica, institutos da indústria e } \\
\text { da tecnologia }\end{array}$ \\
\hline Kitakamigawa & Centro de pesquisa industrial, centro tecnológico industrial \\
\hline Akita & $\begin{array}{l}\text { Centro de material inovador, centro tecnológico local, centro } \\
\text { médico para idosos }\end{array}$ \\
\hline Myagi & Centro de pesquisa \\
\hline Yamagata & $\begin{array}{c}\text { Centro de pesquisa para criação de tecnologia, centro de } \\
\text { pesquisa em alta tecnologia }\end{array}$ \\
\hline Koriyama & Centro tecnológico industrial \\
\hline Shinanogawa & $\begin{array}{c}\text { Parque de software, centro de desenvolvimento da Tecnópolis, } \\
\text { centro de promoção do desenvolvimento da pesquisa e } \\
\text { educação }\end{array}$ \\
\hline Utsunomiya & $\begin{array}{c}\text { Laboratório de mecatrônica, institutos industriais regionais, } \\
\text { institutos de física e tecnologia }\end{array}$ \\
\hline Hamamatsu & $\begin{array}{l}\text { Centro integrado de pesquisa em foto-informação, centro de } \\
\text { eletrônica, órgãos de pesquisa de comportamento }\end{array}$ \\
\hline Toyama & $\begin{array}{c}\text { Empresa de desenvolvimento tecnológico, centro de pesquisas } \\
\text { de biotecnologia, centro de intercâmbio de tecnologia }\end{array}$ \\
\hline Nishiharima & Laboratórios ciência da vida \\
\hline Hiroshima-Chuo & $\begin{array}{l}\text { Órgãos de P \&D, centro de desenvolvimento de tecnologia, } \\
\text { centro de pesquisa em ciência dos materiais }\end{array}$ \\
\hline Kagawa & $\begin{array}{l}\text { Pesquisas e experimentos, cidades para experimentação de } \\
\text { tecnologia viva }\end{array}$ \\
\hline Ehime & Centro tecnológico, centro de informação técnica industrial \\
\hline Kurume-Tosu & $\begin{array}{l}\text { Parque de pesquisa e desenvolvimento, centro de informação } \\
\text { integrada }\end{array}$ \\
\hline
\end{tabular}

\subsubsection{Avaliação do Programa nas Regiões}

Castells \& Hall (1996) fornecem interessantes observações com base em visitas às regiões japonesas realizadas em 1990, as quais servem para uma avaliação das ações estruturantes aplicadas para implementar o projeto nestas áreas e uma avaliação do desenvolvimento regional das Tecnópolises. A seguir 


\section{Desenvolvimento Industrial Descentralizado}

são transcritas as observações dos pesquisadores sobre as quatro áreas por eles visitadas.

\subsubsection{Myagi}

Primeiro, Castells \& Hall descrevem a cidade-mãe de Sendai como um local que não possuía vocação para um projeto de alta tecnologia, conforme previa o plano do MICI. Ela era muito próxima de Tóquio, cerca de $100 \mathrm{~km}$, e seus administradores municipais, achavam que sua região já estava suficientemente explorada e já havia atingido o máximo de seu desenvolvimento. $\mathrm{Na}$ região havia 10 universidade, sendo a principal delas a Universidade de Tohoku, reconhecida como referência em pesquisas com semicondutores, além disso havia 10 escolas e colégios técnicos. Sua produção industrial era principalmente voltada para eletrônicos e mecatrônica, novos materiais, biotecnologia e sistemas de informação urbana.

Esta região é conhecida no Japão pelos belos campos e nestas áreas rurais foram construídos, pela iniciativa privada, vários parques industriais. Dois destes empreendimentos se destacam: o Parque Industrial do Distrito Parque de Izumi e o Parque Industrial e de Pesquisa de Sendai.

O de Sendai possui uma área de 500 hectares, que além de terrenos também oferece que oferece o 21 st Century Plaza, onde se centraliza toda a pesquisa da região, que tem a vantagem de oferecer atualizações constantes em alta tecnologia aplicável nos setores industriais locais, permitindo uma constante aproximação entre o meio acadêmico local e as indústrias.

Este projeto, como quase todos projetos do programada do MICI do Japão, tem previsão de se completar em 2000. Até lá, espera-se, que o programa permita o surgimento nesta área de iniciativas locais, envolvendo o meio acadêmico e empresarial, que assumam o processo de desenvolvimento tecnológico regional através de organizações não-governamentais.

Mas, até a visita de Castells \& Hall, todas as iniciativas de estruturação tecnológica tinham vindo ou do governo ou da iniciativa privada, esta com estruturas como o Centro de Treinamento Profissional Regional, que provém os trabalhadores de qualificação atualizada para atuação nas empresas de alta tecnologia, e o Centro 21st Century Plaza de Kenko, com laboratórios 


\section{Desenvolvimento Industrial Descentralizado}

incubadoras, projetado e gerenciado por uma organização não-governamental sem fins lucrativos.

O 21st Century Plaza de Kenko projetou, ainda, a construção de um pequeno centro de convenções com um auditório, já executado, e além disso, no futuro, contará com um centro de serviços para negócios, um hotel, uma feira de negócios, um parque industrial desenvolvido com base em pesquisa e uma Universidade de Ciência e Tecnologia.

Castells \& Hall acharam interessante observar que o Parque Industrial do Distrito Parque de Izumi, que fica em um local próximo ao anterior, foi iniciado em 1972, precedendo o programa em 14 anos. Dentro de sua área, que totaliza 1.030 hectares, foi criado um novo distrito sendo o projeto uma iniciativa empresarial do conglomerado Mitsubishi, através de sua subsidiária imobiliária. $\mathrm{O}$ desenho se preocupou em reservar o espaço para as atividades industriais e também para a moradia, se preocupando que os trabalhadores tivessem uma boa qualidade de vida e condições para viver próximo ao local de trabalho.

Em 1990, o setor residencial possuía 13.500 habitações, sendo 10.000 delas para famílias casais sem filhos, a população flutuante é de 50.000 pessoas. este projeto de desenvolvimento imobiliário é considerado o maior em área totalmente urbanizada do Japão. Mas, embora se tenha perseguido uma autonomia total com relação à dependência regional, hoje seus moradores têm suas atividades cotidianas, como estudos, compras e serviços dependentes de Sendai.

A área industrial estava, na visita de Castells \& Hall, cerca de 45\% ocupada com 36 companhias produzindo principalmente eletrônicos e novos materiais, entre elas se destacam Motorola, Toyota e Toshiba.

Outro destaque com relação ao projeto de ocupação diz respeito área recreacional, cerca de $15 \%$, que para os padrões japoneses é alto, sendo considerado um padrão de alta qualidade ambiental.

É importante observar que originalmente o projeto era dirigido ao mercado de terrenos industriais e para edifícios comerciais, porém com o programa do MICI das Tecnópolises o projeto foi modificado para atender as exigência do programa sendo incluídos, então, o centro de pesquisa 21 st. Century 


\section{Desenvolvimento Industrial Descentralizado}

Plaza e oferecidos terrenos para locação com aluguéis abaixo do valor de mercado para empresas de alta tecnologia.

Uma outra interessante experiência foi a do Plano Cosmos Inteligente de Tokohu, que se preocupava com o desenvolvimento tecnológico regional. Este plano era associado com o programa de Tecnópolis mas não fazia parte legalmente dele, sendo iniciado em 1987 e finalizado em 1989 através de uma parceria entre departamentos da prefeitura, da universidade e alguns setores empresariais. Seu objetivo era alcançar um pleno desenvolvimento regional que seria assegurado através de uma estrutura científica de pesquisa tecnológica sistematizada através da institucionalização da fundação de organizações de pesquisa e desenvolvimento, as quais que apesar de privadas eram financiadas por dinheiro público. Deve-se destacar que estes investimentos eram de capital de risco de origem governamental com a característica de que não teriam previsão de retorno, entretanto participariam de eventuais lucros vindos de permissão de uso de patentes. Uma outra estratégia do plano Cosmos era encorajar as atividades nas incubadoras para se apropriar das pesquisas básicas desenvolvidas e encontrar formas de aproveita-las economicamente nas indústrias existentes e nas novas que surgiam. As incubadoras eram vistas mais como organizações estruturantes da atividades industriais do que propriamente estruturas produtivas físicas.

\subsubsection{Shinanogawa}

Tendo a cidade mãe de Nagaoka como centro da região, a Tecnópolis de Shinanogawa tem uma área de 130.000 hectares e está sob jurisdição de Niigata, é modelo para o programa das Tecnópolises do MICI. Para se chegar a ela, distante uma hora e meia de Tóquio, utiliza-se o maior túnel sob terra do mundo que fica embaixo dos Alpes Japoneses por onde corre o trem bala Joetsu Shinkazen.

A Tecnópolis foi aprovada pelo MICI em 1985 e teve como base a Universidade Nacional de Tecnologia, criada em 1980, que desenvolveu um plano de desenvolvimento regional baseado em tecnologia e engenharia. Este plano partiu do princípio que o desenvolvimento de indústrias de alta tecnologia poderia ser obtido através de um aprimoramento da base industrial existente na região dando ênfase em introduzir novas tecnologias nas já existentes empresas locais. 
III. Desenvolvimento Industrial Descentralizado

A base industrial regional tradicional era baseada em metalurgia e têxteis, e se caracterizava por uma grande ociosidade. Especialmente, visando introduzir as novas tecnologias nestas indústrias, foram criados, pelo governo da jurisdição de Niigata, um Centro de Tecnologia Industrial e um Centro de Coordenação Tecnológica na Tecnópolis. O objetivo era estimular a atração de novas indústrias nas áreas de automação industrial, novos materiais, software e design, biotecnologia e moda, que assim contariam com um apoio para se integrar à base produtiva industrial existente na região, modernizando-as e trazendo novas tecnologias para os processos produtivos já existentes.

Uma estrutura chave da Tecnópolis é sua incubadora de pesquisas encarregada de dar suporte às empresas na introdução de alta tecnologia nos processos produtivos, treinar o pessoal que irá, por sua vez, treinar a mão-de-obra na utilização de alta tecnologia e que serve de canal para acesso a novas informações tecnológicas. A implantação da Incubadora teve início como o Centro de Pesquisa, em 1984, para exposição e divulgação de tecnologias locais, e dar apoio com pesquisa e desenvolvimento de produtos utilizando novos materiais e novos métodos desenvolvidos para racionalizar processos, sendo quatro as áreas escolhidas: novos materiais, computação, automação industrial e biotecnologia. Um enfoque, que viria a ser assumido pela incubadora, também era destaque na atuação do Centro de Pesquisa: treinamento nas fábricas para técnicos em desenho de moda e telecomunicação. Mas, foi em 1990, com a contratação de consultores que vieram com a tarefa de estimular novos empreendedores tecnológicos que a Incubadora realmente passou a atuar concretamente, procurando identificar potenciais projetos para investimento de capitais de risco e difundir de novas tecnologias nas tradicionais indústrias da região. A integração com o Centro de Pesquisa já vinha se dando com o uso de laboratórios compartilhados pelos pesquisadores do Instituto Nacional de Tecnologia, que a princípio estavam envolvidos apenas com pesquisa e desenvolvimento, mas agora passaram também a se dedicar a difusão de informação tecnológica entre os industriais, um papel fundamental para o sucesso do plano de implementação da Tecnópolis.

Uma outra característica dessa Tecnópolis é o elevado número de parques industriais, totalizando 29 em construção durante o ano de 1990. Esta estratégia visava dar infra-estrutura adequada e deverão ser oferecidos para as 


\section{Desenvolvimento Industrial Descentralizado}

empresas que convergem para a região a valores subsidiados. Outros fatores atraentes da região são a mão-de-obra qualificada e com custos menores do que no corredor Tokaido (Tóquio - Osaka) e o fácil acesso a Tóquio através do trem bala ou pela rodovia expressa. Houve um cuidado especial na localização dos parques industriais que foram construídos em torno de um novo e aprazível distrito, iniciado antes da designação da região como Tecnópolis. Este empreendimento porém não estava sendo ocupado com a taxa esperada, mostrando que a meta de 40.000 moradores ainda demoraria a ser atingida, sendo apenas 5.000 os moradores em 1990. Para aumentar a atração do local autoridade regionais estão estudando a possibilidade de construir um parque temático sobre tecnologia espacial em parceria com a agência espacial japonesa e investidores privados, e também implantar um Parque Nacional destacando a flora e fauna regional. Os idealizadores do plano acreditam que este tipo de investimento se justifica por incentivar o lazer, obtendo uma compensação pelas atividades produtivas stressantes e, desta maneira, estimular e facilitar a criatividade dos habitantes da Tecnópolis.

É interessante observar um ponto fundamental que diferencia a Tecnópolis de Shinanogawa: a expectativa de resultados não é de curto prazo, a previsão para resultados significantes do plano é de 10 a 20 anos, após a conclusão da infra-estrutura e seu objetivo primordial é o desenvolvimento tecnológico das empresas existentes na região, buscando-se um equilíbrio de ocupação das atividades industriais na região com a chegada das novas empresas, as quais deverão dividir igualmente os investimentos com as empresas tradicionais que já atuavam na região antes da implantação do plano do MICI do Japão.

\subsubsection{Oita}

A Tecnópolis de Oita era a mais singular entre as 26 implantadas pelo MICI japonês até 1990. Localizada na ilha de Kyushu, distante cerca de 1.000 quilômetros de Tóquio, entre montanhas e completamente isolada de outros centros urbanos, ela é acessível por um vôo que leva 2 horas a partir do aeroporto de Tóquio. Na província de Oita residem 1.200 .000 pessoas, a cidade mãe de Oita tem 400.000 habitantes, a renda per capita regional atingia, em 1990, cerca de 


\section{Desenvolvimento Industrial Descentralizado}

$83 \%$ da renda média nacional. As atividades econômicas principais regionais eram agricultura, madeira e pesca, as quais detinham $56 \%$ da força de trabalho da região.

Castells \& Hall consideraram que esta Tecnópolis fugia completamente do padrão das outras pela sua caraterística rural, sem qualquer tradição industrial, sua principal atração é seu Parque Nacional e sua reconhecida terra fértil, ideal para o desenvolvimento da agricultura. Portanto, não apresentava os requisitos mínimos exigidos para reivindicar o reconhecimento como Tecnópolis que eram: a existência de uma base industrial e acesso expresso por rodovia e ferrovia, embora já contasse com um aeroporto internacional construído para facilitar o aproveitamento turístico do Parque Nacional. Porém a região tinha um forte aliado para ser incluída no plano do MICI: Morihiko Hiramatsu, um exhomem forte do MICI do Japão e conhecido internacionalmente por promover a atração de indústria estrangeiras para o Japão e um dos idealizadores do programa de Tecnópolis, chegando a ser conhecido como Mr. Technopolis. Hiramatsu tinha fortes relações com os políticos da província pois, além de ter sido governador em 1979, também era originário de Oita, onde morava sua família, e tinha ficado famoso por ser um político contrário ás normas burocráticas. Sua luta contra os executivos do MICI contrários a idéia de uma Tecnópolis na região foi vencedora com o MICI planejando investimentos para criar um novo distrito em Oita e viabilizando a região para sediar uma Tecnópolis.

O plano de Hitamatsu tinha 4 pontos estratégicos para atrair investimentos de alta tecnologia para sua região: o ambiente local favorável para a recepção de investimentos externos na região, a alta qualidade de vida para a mãode-obra, o acesso adequado para passageiros e cargas em seu aeroporto internacional e seu comprometimento pessoal nos projetos a serem instalados na região que poderiam contar com sua colaboração, especializado que era em processos industriais ligados aos segmentos de semicondutores, adquirido em sua experiência no MICI.

O grande problema da Tecnópolis de Oita é sua dificuldade de acesso e sua distância a qualquer rodovia expressa ou ferrovia rápida, bem como a localização do aeroporto, distante da Tecnópolis o que pesa negativamente para os executivos dos conglomerados que valorizam muito seus tempos. Estes problemas 


\section{Desenvolvimento Industrial Descentralizado}

foram parcialmente resolvidos com a conclusão, em 1994, da rodovia expressa que, cortando as montanhas que a cercam, ligou Oita ao sul de Kyoshi.

A região da Tecnópolis de Oita foi dividida em quatro sub-regiões as quais possuem cada uma sua própria pequena cidade mãe. Seu mais importante parque industrial é o de Kitsuki, localizado próximo à nova via expressa que liga Oita ao aeroporto, e que sedia importantes empresas como a Toshiba, a Oita Daihen, a Ishii Tool, a Hoks e a TI. Notar que a Oita Daihen é um filial de uma empresa de Osaka e veio para a região por influência de sue diretor oriundo de Oita, sua especialidade é robótica, transformadores e equipamento de soldagem. Entretanto a razão de sua vinda de Osaka é que estava muito difícil conseguir pessoal especializado de alta qualificação em software, uma necessidade básica para desenvolvimento de produtos em robótica que foi resolvida com a contratação de 40 engenheiros da região que estavam trabalhando em Tóquio e Osaka e desejavam voltar a viver na região. Outro fator de facilidade para recrutamento deste tipo de trabalhador na região é que são poucas as empresa que empregam esta mão-de-obra o que foi um grande atrativo para esta empresa que não encontrou dificuldades para completar seu quadro de técnicos quando iniciou sua instalação em Oita. Ainda, é relevante observar que cerca de 50\% dos engenheiros contratados vinham da Universidade de Oita e desejavam permanecer na região com seus familiares. Para que isto acontecesse eles precisavam de contar com a possibilidade de vir a residir em Oita, constituindo família e contando com os baixos custos de vida da região, o que as autoridades locais vinham assegurando através de investimentos em empreendimentos imobiliários e infraestrutura, como, por exemplo a construção de melhores vias expressas que deverão cortar a região.

Mesmo não sendo a única Tecnópolis localizada em área predominantemente de atividades rurais, Oita se destaca, entre elas, pelo seu sucesso. O plano, iniciado em 1982 e reconhecido pelo MITI em 1984, já em 1990 contava com cerca de 60 companhias instaladas na região. Isto fez com que os empregos na área de tecnologia fosse de 4.000 em 1980 a 21.600 em 1990, representando todo o aumento no mercado de trabalho da província, sendo que 800 destes trabalhadores estão no segmento de software, se dedicando predominantemente a P\&D. Grandes empresas como Sony, Canon, Mtsushita, 


\section{Desenvolvimento Industrial Descentralizado}

Nihon MRC e Daihen estão operando na região, além da Toshiba, com sua subsidiária na área de chips VLSI que é a maior empregadora com 2200 funcionários tendo iniciado suas operações antes da designação da região como Tecnópolis. O total de empresas em funcionamento era de 32 em 1990, entre as novas e as reestruturadas pelo projeto. Estas empresas além de montagem de computadores, também são fabricantes de componentes como micro-ventiladores, placas-mãe, circuitos integrados e outras peças. O número total de empregados era de 4.688, mas deve-se notar que as duas maiores empresas, Kyushu Mtsushita Denhin e TI iniciaram suas operações em 1970 e 1973, respectivamente. Retirando seus funcionários deste total, o número de empregados cai para 3.508, sendo que 2.500 são pessoas da região, o que representa cerca de $0,4 \%$ do total de empregos da província, chegando a $1 \%$ se forem considerados o empregados indiretos. Além disso, a maior parte do trabalho trata-se de rotinas de linha de produção, e embora haja uma pequena instalação de P\&D da Fujitsu, fora da Tecnópolis, os dirigentes das empresas locais duvidam da capacidade técnica da Tecnópolis para $\mathrm{P} \& \mathrm{D}$.

Uma grande vantagem de Oita é o preço de terreno, cerca de 1/3(?) do valor de Tóquio. Outra grande vantagem local é mão-de-obra de qualidade fornecida pela escolas locais, um fator crítico para a produção de circuitos integrados. Um outro grande fator de atração é a atuação do Mr. Tecnópolis, governador Hiramatsu, que através de seu prestígio pessoal conseguido atrair empresas como a Sony, embora para estas empresas a localização da Tecnópolis não seja do ponto de vista logístico a ideal.

É difícil encontrar uma coerência na localização das indústrias na Tecnópolis, o que tem-se é uma grande aglomeração de indústrias de ponta aglomeradas na baía de Oita, a maioria dela vindas para a região antes da inclusão dela no programa do MITI, estimulada pela construção de um aeroporto projetado para cargas aéreas. Existe, ainda, uma grande deficiência para o escoamento da produção dos componentes de computador fabricados pelas indústrias locais, que embora contem com uma boa conexão aérea para Tóquio e Osaka, não dão preferência para este tipo de transporte, como já foi observado o principal meio para escoamento da produção local ainda é o rodoviário, no que a região é ineficiente. Além disso, empresas que utilizavam predominantemente aviões para 


\section{Desenvolvimento Industrial Descentralizado}

transportar sua produção estão abandonando este meio, como é o caso da Canon, grande usuária das companhias aéreas, que em 1990 passou a despachar apenas $10 \%$ de sua carga pelo aeroporto local.

Uma outra deficiência na região de Oita é a pequena participação do meio acadêmico regional nas pesquisas em parceria com as indústrias, que continuam a não acreditar no potencial de $\mathrm{P} \& \mathrm{D}$ das universidades locais, a meta do MITI de conectar a pesquisa universitária com as linhas de produção não está sendo atingida. Assim, se por um lado Oita destaca-se no programa do MITI pela sua performance produtiva no segmento de semicondutores, por outro lado a performance educacional, sem a almejada relação o meio industrial local e o desempenho residencial, a região não vem apresentando atrativos suficientes para atrair novos moradores, deixam a desejar.

Oita forma com Kumamoto, também localizada em Kyushu, a chamado Silicon Island do Japão, tendo ambas o mesmo perfil industrial voltado para o setor de semicondutores, entretanto ao contrário do original Silicon Valley com a maioria dos investimentos trazidos pelos capitais de risco, os investimentos atraídos para as duas Tecnópolises foram principalmente capitais investidos pelos grandes conglomerados empresariais japoneses e também diferente da experiência americana, a aproximação do setor produtivo com as universidades locais, no caso japonês, não foi bem sucedida, sendo as indústrias locais meras reprodutoras de produtos obtidos em centros de P\&D de Tóquio e Osaka.

\subsubsection{Kumamoto}

A Tecnópolis de Kumamoto tem uma área de 95.000 hectares e uma população de 739.000 pessoas distribuídas em uma região que ocupa o oeste de Kyushu, com 2 cidades, 12 distritos e 2 vilas que envolvem o aeroporto regional. A cidade mãe de Kumamoto centraliza as atividades culturais e de serviços e os institutos de pesquisa e as atividades produtivas estão de 10 a 20 quilômetros, formando um amplo corredor, por isso a região é conhecida como a TechnopolisCorredor, ao longo de uma via expressa que forma um cinturão em uma zona, ainda, predominantemente agrícola. Em 1990 a implantação da Tecnópolis estava 


\section{Desenvolvimento Industrial Descentralizado}

ganhando impulso com o início das obras de infra-estrutura, mas havia uma preocupação em preservar a bela paisagem local, onde predominam florestas, e a qualidade de vida que o meio ambiente preservado poderá oferecer, sendo uma vantagem com que esta Tecnópolis conta para atrair pesquisadores e mão-de-obra qualificada para trabalhar nas indústrias de alta tecnologia que deverão se estabelecer na região.

Embora, a designação da região como Tecnópolis tenha ocorrido em 1984, Kumamoto já se destacava como pólo de produção de circuito integrado desde 1980, com as empresas NEC e Mitsubishi, e empresas terceirizadas, produzindo na região cerca de $20 \%$ dos circuitos integrados consumidos pela indústria japonesa. São muitos os fatores que atraem as indústrias de alta tecnologia para esta Tecnópolis: a água fresca e pura que provém em abundância do subsolo da região, o ar puro local, pessoas acostumadas ao duro trabalho industrial, o apoio ativo dos governantes da província e seus excelentes centros de pesquisa e educação tecnológica. Uma outra vantagem de Kumamoto diz respeito ao fato de que o processo industrial recente dá condições para as indústria se instalarem sem fatores negativos como obsolescência de instalações industriais e sistema social exigido por mão-de-obra tradicional, além de contar com o entusiasmo dos jovens trabalhadores que vêm finalmente a oportunidade de trabalhar com um processo industrial não muito cansativo, o que cria uma grande energia favorável ao trabalho com inovação tecnológica.

A região se destaca ainda pelo número significativo de colégios e universidades com excelente nível educacional em engenharia, e, embora, muitos dos alunos graduados tenham saído da região para ir trabalhar em Tóquio e Osaka, os governantes da província têm se preocupado em atraí-los de volta, mantendo escritórios nestas cidades para dar apoio aos que desejarem voltar para a região, oferecendo vantagens, como os baixos custos de moradia, em comparação com as maiores cidades do Japão, para sua recolocação nas indústrias locais.

A Tecnópolis em seu plano de implantação prevê ênfase em quatro setores: automação, biotecnologia, eletrônicos e software, tentando atrai-los com incentivos locais como empréstimos a juros baixos, compra de terrenos a valores subsidiados, isenção de taxas municipais, empréstimos para novos empreendimentos e subsídios para implantar infra-estrutura. A política industrial 


\section{Desenvolvimento Industrial Descentralizado}

da província é não apenas atrair grandes empreendimentos, mas estimular o desenvolvimento das pequenas e médias indústrias regionais, preocupando-se que as grandes indústrias que se instalam na região utilizem os pequenos empreendedores locais não somente como mão-de-obra terceirizada, mas dando condições para que estes pequenos industriais assimilem tecnologia e conhecimento dos novos processos produtivos.

O plano visa não apenas estimular a produção, como também o desenvolvimento da pesquisa na região, facilitando-a com a construção de um parque no centro do corredor da Tecnópolis que irá oferecer, além de laboratórios, moradia, cultura, arte e informação, $O$ plano favorece o relacionamento entre as indústrias e as universidades da região, tentando evitar a deficiência observada em Oita. O melhor exemplo desta estratégia é o Tecno-Parque de Pesquisa de Kumamoto, concluído em 1991, que é o núcleo de desenvolvimento da Tecnópolis e simboliza a Tecnópolis e suas complexas funções. Envolvidos por grandes áreas verdes, nele estão o Centro da Tecnópolis de Kumamoto, Centro de Pesquisas em Eletrônica Aplicada e o Centro de Pesquisa Cooperativada da Universidade de Kumamoto. Futuramente, pretende-se oferecer no mercado imobiliários lotes para empreendimentos tecnológicos. Com o propósito de enfocar mais os processos produtivos, a província tem a pretende construir um parque em outra área da Tecnópolis.

Comparando a stressante vida nas grandes cidades do Japão, como Tóquio e Osaka com a tranqüila e saudável vida na região, foi um produzido um vídeo que é mostrado aos visitantes, em uma sofisticada e altamente tecnológica sala, assim que estes chegam para conhecer a Tecnópolis de Kumamoto. Neste projeção também são destacadas as vantagens regionais econômicas como terra barata e disponibilidade da mão-de-obra qualificada. Ainda, conhecidas belezas naturais e a tranqüilidade da vida rural, bem como fatores como cultura, vida intelectual e qualidade do ensino.

Tendo como meta criar sinergia entre empresas locais e o meio acadêmico e de pesquisa foi criado um centro (Promotion Club for Science and Technology) que estimula o relacionamento entre as três universidades locais e dois colégios técnicos com cerca de sessenta empreendimentos industrias regionais através de regulares, mas descontraídas reuniões sociais. Trata-se de um 


\section{Desenvolvimento Industrial Descentralizado}

experimento para promover uma integração entre os práticos homens de negócios com os pesquisadores universitários que traz conhecidos empresários, cientistas e pesquisadores para falarem de suas experiências bem sucedidas que são relatadas também em um jornal publicado pelo centro.

Com estratégia a Tecnópolis de Kumamoto dá prioridade a atração de novas empresas e para isto releva seus fatores mais vantajosos para isto. Assim, a qualidade da mão-de-obra e do meio ambiente local e as vantagens oferecidas para recuperar os qualificados profissionais naturais da região são os fatores principais do plano. A escassez de moradia, um fator crítico da região, vem sendo atacada por empreendimentos imobiliários em torno do Parque de Pesquisa.

Os mais importantes incentivos financeiros: relaxamento da taxação federal sobre equipamentos e territorial urbana, e oferecimento imediato de áreas para instalação de indústrias, que são oferecidas a valores menores que do mercado. Destaca-se, ainda, que as terras por serem em zona agrícola são negociáveis apenas com autorização do governo.

O maior esforço tem sido em aprimorar a capacidade tecnológica regional. Desta forma, cerca de 3500 computadores foram doados ás escolas públicas locais pela administração regional. Novas empresas locais são estimuladas a serem abertas com garantia de apoio ao desenvolvimento tecnológico através do centro de Pesquisa Eletrônica Aplicada e também crédito a juros baixo. Outra atividade do centro é o treinamento de jovens estudantes recém-formados nas escolas técnica, dando ênfase a cursos de gerenciamento tecnológico, sendo que apenas após dois anos são colocados no mercado de trabalho local.

O plano da Tecnópolis de Kumamoto é tido como responsável pelo aumento dos postos de trabalho em cerca de 30\% entre 1980 e 1990, mas, a expectativa é que atinja $130 \%$ ao final da implantação. Um grande parte do empregos vêm de firmas de software que vieram de fora. Entretanto as autoridades locais acreditam que para que o plano seja completamente bemsucedido há necessidade de se criar uma base industrial que estimule a sinergia com estas chamadas "software houses".

\subsubsection{Conclusão sobre o Programa Japonês}




\section{Desenvolvimento Industrial Descentralizado}

Segundo Castells \& Hall, para avaliar o programa das Tecnópolises japonesas, deve-se questionar, a princípio, em termos de números realistas, quantas novas fábricas foram criadas e quantos empregos elas trouxeram para as regiões. E, depois, ir um pouco mais fundo, indagar quantas delas são meros braços operacionais controlados por indústrias em outras cidades. Finalmente, então, abordar uma questão estrutural mais profunda: saber até onde o programa conseguiu criar, efetivamente, capacidades de inovação nas regiões da Tecnópolis.

Primeiramente, na questão de números. O MITI afirmava que em 1990 nas 26 áreas as taxas de investimentos industriais foram maiores do que no resto do Japão. Assim, nas primeiras 14 Tecnópolises autorizadas, a média anual durante o período 1984-7 de novos empreendimentos foi de 1,5 contra a média nacional de 1,3 empreendimentos. Mesmo assim, as fábricas locadas nas Tecnópolises foram apenas $6,4 \%$ do total de novas fábricas no país.

Em termos de descentralização da indústria de computadores, houve um certo progresso, embora elas continuassem concentradas nas maiores regiões metropolitanas japonesas (Tóquio e Osaka). Pois, as regiões das Tecnópolises tiveram um aumento no número de trabalhadores neste segmento, indo de $10 \% \mathrm{em}$ 1981 a 12,9\% em 1985, enquanto que a região metropolitana de Tóquio diminui de $61,1 \%$ para 55,8\% no mesmo período. Quanto a Osaka não houve diminuição, mas um acréscimo, indo de 16 para $18 \%$.

Outros números comprovam o sucesso do processo de descentralização induzido pelo Programa das Tecnópolises. Tóquio que detinha, em 1981, 58\% das empresas de software em sua região metropolitana passou para 32 em 1985. A diferença também é significativa na indústria de processamento de informação indo de $30 \%$ para $23 \%$ no mesmo período. A performance de Osaka se repete e mostra uma alta que foi de 16 para $24 \%$ em software e de 11 para $14 \%$ na indústria de processamento de informação. Mas, o desempenho das 14 Tecnópolises foi surpreendente: os estabelecimentos de software cresceram $425 \%$ e $34 \%$ em processamento de informação. Estes números vieram quase que inteiramente em decorrência da atuação de pequenas e médias empresas de alta tecnologia independentes, tendo em vista que houve um decréscimo do número de filiais das grandes empresas nas regiões das Tecnópolises, enquanto se constatou 


\section{Desenvolvimento Industrial Descentralizado}

um crescimento do número de empregos menor que o crescimento de novas firmas locais.

O número dos negócios realizados nas regiões também comprovavam que houve uma expansão na exportação dos produtos regionais, e se em 1981 as 14 regiões produziam 7,9\% e consumiam $8 \%$ da produção nacional, em 1985 elas produziam $9,4 \%$ e consumiam $9 \%$.

Existiam, em 1990, conclusões negativas a respeito dos resultados do programa das Tecnópolises, baseando-se em 3 índices: valor da produção de bens manufaturados, empregos industriais e população. Totalizando-se estes índices para as 26 Tecnópolises eles apresentavam em 1990, um resultado, que, embora insignificante, era positivo, porém o mesmo não acontecia quando estes índices eram aplicados em 18 das regiões. Podia-se concluir, então, que nas outras 8 Tecnópolises, os valores positivos deveriam ser revistos pois deveriam estar refletindo, principalmente, o desempenho unicamente da cidade-mãe e não da região como um todo.

$\mathrm{Na}$ verdade, a questão vai mais longe do que uma simples abordagem numérica, segundo Castells \& Hall, é necessário uma abordagem sobre o relacionamento entre as cidades metropolitanas e as regiões das Tecnópolises para verificar se estas continuavam com suas economias subordinadas a Tóquio e Osaka, um problema crucial que o programa das Tecnópolises pretendiam amenizar. E, neste ponto, existe uma visão, compartilhada entre pesquisadores americanos e japoneses e os autores do estudo, que apontaram para o programa japonês os seguintes problemas:

1. Falha em adotar a visão original - A integração das cidades satélites às facilidades educacionais e de pesquisa e desenvolvimento das cidades-mãe não foi bem sucedida, bem como a utilização das infra-estruturas para implantação de indústrias de alta tecnologia pelas empresas locais das cidades satélites. Muitas destas cidades continuam sendo simples satélites, mesmo os novos distritos que foram criadas especialmente para o plano, com suas subsistências dependentes da terra e mão-de-obra baratas. 
III. Desenvolvimento Industrial Descentralizado

2. Síndrome do braço operacional - As indústrias descentralizaram a produção entretanto seus braços operacionais permaneceram como simples produtores de partes para serem despachadas pelas indústrias de Tóquio e Osaka, ou atuando apenas como montadoras. Assim, muito pouca transferência de tecnologia tem ocorrido entre as indústrias que chegam e as fábricas locais. É por isso que as administrações regionais vêm se esforçando para criar centros de pesquisas próprios que facilitem o desenvolvimento tecnológico local. Não tem havido uma preocupação para que o desenvolvimento tecnológico não se faça apenas para atender a produção de partes do produto tecnológico nem apenas para aprimorar as montagens destes produtos, mas que ele contribua para a inovação tecnológica dos processos produtivos. Isto deve ser visto como um fator importante para o desenvolvimento de uma economia local baseada em P\&D.

3. Falha para desenvolver a ligação universidade-indústria - Ligações próximas entre indústrias locais e universidades como existem em Cambridge ou Stanford são inexistentes no Japão. Elas não acontecem por causa da forte regulamentação da atuação das universidades públicas japonesas, o que tem provocado uma falta de habilidade do meio acadêmico em desenvolver trabalhos fora do âmbito da universidade. Desta forma, embora existam relações entre as universidade locais e as indústrias regionais elas se dão pela atuação das administrações regionais que disponibilizam suas infra-estruturas para o desenvolvimento das pesquisas. $\mathrm{O}$ Programa de Tecnópolis também não conseguiu resolver o problema de escassez de profissionais de alto nível para as pesquisas que preferem permanecer nas universidades de primeira linha, que se localizam nas regiões metropolitanas e que oferecem melhores oportunidades de trabalho devido à proximidade com as matrizes das grandes indústrias.

4. Escassez de infra-estrutura leve - A atuação das administrações regionais e do governo federal ficou concentrada em resolver 
III. Desenvolvimento Industrial Descentralizado questões de infra-estrutura pesada como estradas, aeroportos, instalações para as universidades, laboratórios, centros tecnológicos e parques industriais e de pesquisa, preocupando-se muito pouco com questões como consórcios para $\mathrm{P} \& \mathrm{D}$, capitais de risco e pesquisa acadêmica dirigida para os objetivos do Programa. $\mathrm{Na}$ maior parte das regiões não foi criada uma atratividade suficiente para atrair as empresas de ponta, seja pela deficiente infra-estrutura ou pela falta de um ambiente de pesquisa realmente inovador.

5. Fracasso em deslocar P\&D - As maiores corporações industriais relutam em transferir suas unidades de pesquisa dos grandes centros urbanos para as províncias. Isto se deve, principalmente pela estratégia de logística que está ligada ao modo de produção onde as fábricas centrais se tornaram laboratórios de desenvolvimento de novos produtos, sendo as filiais braços de produção de produtos padronizados unicamente dos protótipos desenvolvidos nas matrizes.

6. Escassa integração entre indústrias - Um fator chave para o sucesso do plano seria a integração entre as grandes corporações que chegam às regiões e as indústrias locais. Entretanto isto não acontece, pois as indústrias locais são meras reprodutoras de produtos desenvolvidos pelas matrizes e com padrões pré estabelecidos nada há que se possa acrescentar. Desta forma, os centros de pesquisa e desenvolvimento, que acolheram grandes recursos de investimentos, estão ociosos deixando de atuar na transferência de tecnologia para as empresas locais uma das metas do Programa de Tecnópolis.

7. Falta de spin-off - Um fator de sucesso em Stanford, a crescente produtividade local a partir da chegada das empresas não ocorreu. Repete-se o mesmo raciocínio aplicado no item anterior: a falta de motivação pela simples adoção de produtos padronizados pelas matrizes que não cria o desejável spin-off que seria conseqüência da integração crescente entre os agentes produtivos locais e as 
III. Desenvolvimento Industrial Descentralizado cadeias produtivas geradas pelas grandes indústrias. E, mesmo as software-houses, que aumentaram significativamente nas regiões das províncias, se encontram agora em um beco sem saída para permanecerem crescendo: são fornecedoras, geralmente, de alguns grandes clientes, o que não garante a livre concorrência.

8. Falha em atrair trabalhadores-chave - A região de Tóquio concentra cerca de $60 \%$ da mão-de-obra especializada em médias e pequenas empresas do setor de tecnologia de informação, isto causou uma escassez de trabalhadores qualificados que pudessem atender o Programa de Tecnópolis.

9. Carga fiscal local - Existe um perigo potencial provocado pela competição entre as localidades na qual umas poucas sobreviverão enquanto a maioria não irá suportar os altos custos para investir nas infra-estruturas básicas onde o setor privado não tem mostrado interesse em participar, como habitação e galpões industriais. Os investidores têm preferido colocar dinheiro em investimentos com maior taxa de retorno, como os próprios setores de alta tecnologia que vêm crescendo acima de qualquer outro tipo de aplicação.

10. contínuo desafio de além-mar - $\mathrm{O}$ crescimento do valor do yen frente ao dólar tem forçado os conglomerados japoneses a abrir filiais de suas indústrias em países com menor custo, na Ásia ou Europa, para continuarem competitivos. Isto faz com que o fluxo de transferência de tecnologia de Tóquio e Osaka para as regiões periféricas do Programa seja reduzido ainda mais.

Tecendo estas considerações, Castells \& Hall, ainda concluíram:

- primeiro, o programa das Tecnópolises japonesas não havia conseguido até 1990 muito sucesso em gerar novas atividades na maioria das regiões que faziam parte deste programa. Isto ocorreu devido a uma divisão entre as regiões que estão localizadas próximas, no máximo a 300 quilômetros de Tóquio, e por isso foram bem sucedidas em atrair laboratórios e algumas fábricasmãe, e as outras regiões mais afastadas que não conseguiram isto; 
III. Desenvolvimento Industrial Descentralizado

- segundo, a estratégia de promover a construção, estruturação e operação de plantas de filiais, que têm pouca capacidade de inovação tecnológica e são altamente vulneráveis às flutuações do cenário econômico internacional e da competição no comércio exterior, não favoreceu o desenvolvimento regional nem $\mathrm{o}$ nacional, como era objetivo do programa, pois estes braços operacionais das grandes indústrias não oferecem estabilidade no desenvolvimento econômico e tecnológico regional.

De forma geral, Castells \& Hall perceberam que o programa original tinha a preocupação de estabelecer áreas e regiões onde o ambiente favorecesse a $\mathrm{P} \& \mathrm{D}$, sendo necessária uma integração entre o setor privado e o setor público, o que não ocorreu, pois unicamente o setor público até então havia investido em infra-estrutura e equipamentos para a pesquisa e desenvolvimento tecnológico. E também a participação do governo federal em estimular o programa privilegiou algumas regiões, isto acabou criando de fato uma grande Tecnópolis: Tóquio Yokohama Mega Tecnópolis, não atingindo a descentralização industrial desejada.

Porém os pesquisadores reconhecem que as iniciativas do Japão em estruturar adequadamente suas regiões periféricas no cenário tecnológico que se descortina são pioneiras e como tal são suscetíveis a erros pois avançam em territórios do conhecimento e do desenvolvimento baseado tecnologicamente, que ainda são pouco explorados e não podem ser fundamentados em experiência nacionais de vulto como a que os japoneses se propuseram a fazer, pois ainda não ocorreram com esta abrangência nacional em nenhum dos países industrializados.

Vê-se, assim, que a combinação de iniciativas locais com nacionais para manter uma liderança global tecnológica e avançar em inovação tecnológica faz do Japão o centro das atenções pela amplitude e ambiciosa perspectiva, porém a grande dificuldade será vencer a extrema rigidez estrutural de sua economia fundamentada na sólida aliança entre as empresas e o governo, o que pode dificultar o processo criativo necessário para a indução da inovação tecnológica, terreno onde a agilidade das estruturas produtivas tem papel fundamental, pois há uma imposição permanente para se adaptar às novas e constantes transformações decorrentes da competitividade global. 
III. Desenvolvimento Industrial Descentralizado

\section{Desenvolvimento Industrial em Londrina}

\subsection{Histórico do Desenvolvimento Local}

A história de Londrina, pode-se dizer, iniciou-se após o final da Primeira Guerra Mundial, conforme conta Cernev (1997). O Brasil estava diante de uma grave crise econômica e financeira e para enfrentar essa situação o então presidente Artur Bernardes pretendeu fazer uma reformulação no sistema tributário nacional, em que os pontos básicos consistiam em abolir os impostos diretos e a instituição de uma nova e eficiente sistemática de arrecadação. Solicitou, para isso, a ajuda de técnicos e financistas ingleses que chegaram ao Rio de Janeiro em 30 de dezembro de 1923.

Baseando suas pesquisas em publicações oficiais $^{1}$ da empresa colonizadora Companhia de Terras Norte do Paraná, Cernev relata os fatos que se sucederam com a vinda da Missão Montagu ao Brasil e que viriam a culminar com a fundação de Londrina.

A missão era chefiada por Lord Montagu (Edwin Montagu), exsecretário de Estado para as Índias e ex-secretário financeiro do tesouro, sendo integrada por vários assessores, dentre os quais se destacavam Sir Charles Addis, diretor do Banco da Inglaterra e presidente da Hong Kong and Shangai Banking; Sir Hartley Withers, comentarista de assuntos financeiros e ex-diretor do The Economist de Londres, e Lord Lovat (Simon Joseph Frazer), diretor da Sudan Cotton Plantations Syndicate, assessor para assuntos de agricultura e reflorestamento.

Além de viajar como assessor da Missão Montagu, Lord Lovat tinha como incumbência dos acionistas da Sudan Plantations estudar a possibilidade de vir essa poderosa companhia inglesa a aplicar seus capitais no Brasil, de forma a obter o algodão que importava em larga escala para suprir a florescente indústria têxtil da Inglaterra.

Lord Lovat adiantou-se à comitiva visitando São Paulo, Ribeirão Preto, Rio Claro e Americana, passando depois pelo Norte do Paraná, onde ficou 


\section{Desenvolvimento Industrial Descentralizado}

impressionado diante da fertilidade das terras roxas e dos resultados obtidos nas lavouras de algodão.

Em sua viagem ao Norte do Paraná, em janeiro de 1924, Lord Lovat foi acompanhado por Gastão de Mesquita Filho, engenheiro responsável pela construção da estrada de ferro que ligaria Ourinhos a Cambará, onde encontrou Willie Davids, então prefeito de Jacarézinho.

Conta Cernev, ainda, que depois de conhecer a fazenda de Antonio Barbosa Ferraz Júnior, Lord Lovat fez uma tentadora proposta para comprá-la, proposta essa que foi recusada. No entanto o interesse do ilustre visitante foi desviado para as terras situadas mais à frente, igualmente fertilíssimas e que eram oferecidas pelo Governo do Estado do Paraná a preços muito baixos, face à inexistência de estradas e, portanto, às dificuldades de acesso.

Gastão de Mesquita Filho, segundo Cernev, foi quem conseguiu convencer Lord Lovat a lançar-se nesse novo empreendimento: uma colonização bem planejada, tendo como pontos principais a fertilidade das terras e a garantia de boas vias de acesso, estando aí incluída a construção de uma estrada de ferro. O argumento mais atraente apresentado ao visitante foi a rápida valorização das terras ocorrida na região de Cambará, com a construção da ferrovia: uma valorização de mil por cento em um ano.

Encantado com as possibilidades que estavam se apresentando, Lord Lovat passou um telegrama para Arthur Hugh Miller Thomas, diretor da Sudan Plantations para que este seguisse de Cartum diretamente para Londres, onde se encontrariam para discutirem as possibilidades de aplicação de capitais ingleses no Brasil.

Em Londres os sócios da Sudan Plantations, animados com o relatório recebido, decidiram investir no Brasil, sendo então organizada a Brasil Plantations Syndicate Ltd., com um capital de 200 mil libras, e cuja presidência coube a Lord Lovat. Retornando a São Paulo, Arthur Thomas que juntamente com João Sampaio e seu sócio Antonio de Moraes Barros organizou a Companhia de Terras Norte do Paraná - CNTP, subsidiária da companhia inglesa. Seus estatutos foram registrados a 24 de setembro de 1925, com um capital inicial de 1.000 contos de réis. 
III. Desenvolvimento Industrial Descentralizado

A CTNP, com sede em São Paulo, era pessoa jurídica brasileira, sob a direção de brasileiros e seria a adquirente e vendedora das terras do Norte do Paraná, assim teve como primeiro presidente o Dr. Antônio de Moraes Barros. Como uma sociedade anônima seria controlada, acionariamente, pela Paraná Plantations, de Londres, de onde viria todo o dinheiro necessário em conta corrente.

Conta Cernev, que face aos entendimentos mantidos com o Governo do Estado do Paraná, em Londres foi tomada a decisão de ampliar a atuação da Companhia, partindo para a colonização, além da venda de terras. Quando se discutia sobre a necessidade de aumentar o capital da Brazil Plantations, por sugestão de João Sampaio, foi tomada a decisão de liquidar essa companhia, criando os mesmos acionistas em seu lugar a Paraná Plantations Syndicate, que iria cuidar da construção de estradas de ferro e de rodagem.

O interesse demonstrado pelos ingleses teve repercussão imediata: muitos possuidores de títulos de concessão vieram oferecer tais propriedades aos representantes do grupo inglês no Brasil. Arthur Thomas e João Sampaio decidiram ir a Curitiba, estabelecendo negociações diretamente com o Presidente do Estado, Dr. Caetano Munhoz da Rocha.

Depois desses entendimentos iniciais, deu-se a compra de vasta área de terras pertencentes ao Estado, sabendo-se de antemão que muitas delas estavam em mãos de "grileiros"2.

Mas a responsabilidade pela liquidação das posses ilegítimas, segundo o acordo, ficaria por conta da Companhia. Para regulariza-las, muitas das terras que haviam sido adquiridas do Estado, a preço de lei, foram pagas ainda uma ou mais vezes àqueles que apresentaram títulos de propriedade, mesmo sabendo-se de sua discutível legitimidade, pois na ocasião as terras foram consideradas como de valor muito baixo.

Depois de adquiridas as terras e decidida a questão de promover seu loteamento e venda - abandonando o projeto inicial da cultura e industrialização do algodão - uma das primeiras preocupações da CTNP foi a de proceder a um cuidadoso levantamento topográfico da região. 


\section{Desenvolvimento Industrial Descentralizado}

Começando pelas terras mais próximas, situadas na parte oriental, logo após a transposição do rio Tibagi, os lotes foram sendo demarcados e colocados à venda de forma racional. A ocupação do território se deu de maneira ordenada e estrategicamente não permitiu o aparecimento de núcleos distantes e isolados entre si.

Registrou-se no Norte do Paraná um avanço gradual e sistemático da colonização, o qual Cernev observou, era baseado no modelo aplicado nos Estados Unidos, Canadá e Austrália, onde a ocupação territorial e as atividades econômicas se concentravam em faixas do território e, na medida em que se achasse plenamente utilizada, estenderiam-se para outras regiões, caracterizandose esse sistema como de moving frontier.

Definida a atividade colonizadora, a CTNP iniciou a venda dos lotes em 1930, na região de Londrina, sendo que os primeiros lotes rurais foram vendidos a colonos japoneses, trazidos pelo infatigável agente de vendas Hikoma Udihara. Vieram depois os alemães, que se estabeleceram na proximidade do núcleo urbano, fundando a colônia do Heimtal.

Em face da boa aceitação inicial, apoiada por um eficiente trabalho de divulgação, deu-se um rápido crescimento que, em pouco tempo, oferecia condições para a criação do município em 3 de dezembro de 1934, pelo Decreto n. ${ }^{\circ}$ 2.519, do Interventor Federal Manoel Ribas e sua instalação solene se deu a 10 de dezembro de 1934, desmembrando-se do município de Jatahy.

Pelo que se pode deduzir dos depoimentos e testemunhos dos pioneiros, a preocupação da Companhia estava concentrada principalmente na colonização e aproveitamento da área rural, ficando os núcleos urbanos num segundo plano, destinados a servirem de apoio ao campo. Tal prática é corroborada pela programação dos principais núcleos urbanos.

Cernev observa que Londrina, o primeiro grande núcleo, foi planejada para abrigar uma população de apenas 30 mil habitantes, resguardada por uma área para o "cinturão verde", mais além surgiam os sítios, e só depois é que apareciam as pequenas fazendas. Finalmente, nas áreas mais afastadas, localizavam-se as grandes fazendas.

Em redor da cidade a Companhia traçou uma faixa de terras para 


\section{Desenvolvimento Industrial Descentralizado}

serem cortadas em lotes de um, dois e três alqueires, com idéias de serem abertas clareiras para hortas, granjas e pequenas culturas para abastecer a cidade futura com verduras, frutas, leite, etc. Com a passagem do tempo, o crescimento da cidade exigiu espaço $e$, pouco a pouco, a maioria destas chácaras foram loteadas e nelas surgiram subúrbios por todo o lado. Ainda com a idéia de criar maior desenvolvimento possível para o comércio, as terras até $5 \mathrm{~km}$ foram cortadas em sitios, do limite mais ou menos de 5 alqueires somente, e nos outros $20 \mathrm{~km}$ a Companhia não vendeu lotes maiores de 20 alqueires ${ }^{3}$.

Dessa maneira, pode-se perceber que Londrina é resultado de um processo de colonização com características que a tornaram distinta da forma geral com que ocorreu o povoamento e a ocupação do território nacional, conforme pode-se constatar na análise de Cernev. Segundo ele, o sucesso da colonização do Norte do Paraná baseou-se em dois pontos fundamentais:

1. realização de uma verdadeira reforma agrária sob a égide de estritos critérios capitalistas, tendo como principais características: os lotes de terras vendidos a preços de mercado e amplamente financiados; as dimensões das glebas compatíveis com a capacidade de exploração e trabalho de uma família; a receita proveniente das vendas, em grande parte, reaplicada na melhoria da infra-estrutura do empreendimento, especialmente em vias ferroviárias e rodoviárias para escoamento da produção, visando garantir a permanência dos colonos; e

2. unidade cultural baseada em acentuada presença protestante, que viria assegurar o fundamento ético e político para a colonização de iniciativa privada e seu desenvolvimento sob a luz do conceito ideológico liberal, garantindo soluções no nível local através da participação da comunidade em iniciativas empreendedoras independente do suporte financeiro do Estado.

\subsection{Desenvolvimento Industrial}

Porém, se o desenvolvimento urbano de Londrina destaca-se das cidades brasileiras de uma forma geral, quanto ao desenvolvimento industrial Londrina seguiu um processo típico das cidades do interior do Brasil: as 
III. Desenvolvimento Industrial Descentralizado atividades econômicas principais são agropecuária e comércio e, como conseqüência, o setor industrial se desenvolveu apoiado basicamente na transformação de produtos primários.

Com poucos produtos agrícolas e uma industrialização embrionária, formada inicialmente por pequenas indústrias de transformação de produtos primários e, posteriormente, da extração de minerais não metálicos, metalurgia leve e indústrias gráficas, a base econômica de Londrina nas décadas de 1950 e 1960 era fundamentada praticamente na monocultura cafeeira.

Voltadas para o mercado local ou regional, tanto na aquisição de insumos como para a colocação do produto final, as indústrias apresentavam quase sempre baixos níveis tecnológicos.

Londrina, com fatores como sua forte base agrícola da indústria, principalmente o beneficiamento do café e seus bons excedentes da agricultura, deveria ter sido levada a um processo de industrialização similar ao ocorrido em outras regiões cafeeiras. Mas, possivelmente, tendo em vista que os recursos gerados localmente foram, em grande parte, aplicados na industrialização de São Paulo, com pequenos investimentos na região originária da renda, as pretensões industriais da região londrinense ficariam em segundo plano.

Destaca o relato dos consultores da Andersen que a dificuldade para a implantação de indústrias de porte em Londrina fez com que na região se desenvolve uma boa performance no comércio comprador da grande produção agrícola onde atuariam grandes empresas nacionais e multinacionais, com sede fora da cidade. Estas remeteriam os bens adquiridos para outras regiões e para o exterior, onde no processo industrial seriam agregados os valores próprios das atividades industriais, que poderiam fazer parte da riqueza regional se as transformações aqui fossem realizadas.

Entre 1960 e 1990 foi registrado um desenvolvimento industrial envolvendo setores tradicionais como a indústria alimentar e têxtil, caracterizando-se por indústrias pequenas para utilização de matérias-primas fundamentalmente locais. Assim, o parque industrial de Londrina se desenvolveu, e embora ainda não apresentasse expressão no nível nacional, pois suas indústrias eram novas e ainda de pequeno porte na sua maioria, mas na agroindústria surgiu 
III. Desenvolvimento Industrial Descentralizado

uma maior diversificação, fazendo com que se caracterizasse um "cluster" de alimentos em maturação.

O setor têxtil e de confecções também é expressivo, fazendo com que Londrina, ao longo dos últimos anos, alcançasse uma projeção no setor da indústria têxtil. Este "cluster" tem a participação de grandes, médias e pequenas indústrias de confecção as quais vêm ganhando espaço no mercado nacional e internacional. Um fator relevante é o fato da região ser tradicional produtora de algodão, além de se concentrarem produtores rurais de bicho-da-seda e de rami, utilizados na elaboração de fios.

Concluíram os consultores da Andersen que o cenário atual da economia londrinense pode ser melhor analisado, através do auxílio do Fundo de Participação dos Municípios, que fornece a contribuição para cada setor da indústria seu Valor Adicionado Bruto - VAB no PIB da cidade.

A tabela a seguir mostra a importância dos setores Têxtil e de Confecções no PIB de Londrina, contribuindo respectivamente com 12,34\% e $17,26 \%$ do VAB, contribuições inferiores apenas as dos setores de Produtos Alimentares e da Indústria Química. 
III. Desenvolvimento Industrial Descentralizado

Tabela 1 - Participação dos Setores no PIB Industrial de Londrina

\begin{tabular}{|c|c|c|}
\hline Descrição & Número de Empresas & Participação no VAB \\
\hline Produtos Alimentares & 228 & $32,06 \%$ \\
\hline Química & 27 & $17,99 \%$ \\
\hline $\begin{array}{c}\text { Vestuário, Calcados, } \\
\text { Couro e Tecidos }\end{array}$ & 282 & $17,26 \%$ \\
\hline Têxtil & 29 & $12,34 \%$ \\
\hline $\begin{array}{c}\text { Transf. de Minerais não } \\
\text { Metálicos }\end{array}$ & 57 & $5,11 \%$ \\
\hline $\begin{array}{c}\text { Material Elétrico e de } \\
\text { Comunicações }\end{array}$ & 46 & $3,12 \%$ \\
\hline Bebidas & 11 & $1,98 \%$ \\
\hline Mecânica & 42 & $1,97 \%$ \\
\hline Papel e Papelão & 19 & $1,70 \%$ \\
\hline Mobiliário & 66 & $1,47 \%$ \\
\hline Metalúrgica & 72 & $0,98 \%$ \\
\hline Outras & 208 & $4,00 \%$ \\
\hline Total & & $100,00 \%$ \\
\hline
\end{tabular}

Fonte: Fundo de Participação dos Municípios (ICMS) - Secretaria da Fazenda do Estado do Paraná(1993). Em Andersen Consulting (1995).

Com relação ao número de empregos gerados há uma alteração de posições dos setores, conforme pode-se ver na tabela seguinte.

Tabela 2 - Participação dos Setores Industriais na Geração de Empregos

\begin{tabular}{|c|c|c|c|}
\hline Setor & Descrição & $\begin{array}{c}\text { N. }^{\text {o de }} \\
\text { Empregados }\end{array}$ & \% do Total \\
\hline 26 & Produtos Alimentares & 3501 & $16 \%$ \\
\hline 25 & Vestuário, Calcados, Couro e Tecidos & 2887 & $13 \%$ \\
\hline 24 & Têxtil & 2667 & $12 \%$ \\
\hline 13 & Material Elétrico e de Comunicações & 1765 & $8 \%$ \\
\hline 29 & Editorial e Gráfica & 1140 & $5 \%$ \\
\hline 11 & Metalúrgica & 967 & $4 \%$ \\
\hline 16 & Mobiliário & 939 & $4 \%$ \\
\hline 20 & Química & 934 & $4 \%$ \\
\hline 12 & Mecânica & 827 & $4 \%$ \\
\hline & Outros & 3120 & $14 \%$ \\
\hline & Total & 21943 & $100 \%$ \\
\hline
\end{tabular}

Fonte: RAIS 1993. Em Andersen Consulting (1995). 
III. Desenvolvimento Industrial Descentralizado

\subsection{A Comunidade Empreendedora de Londrina}

Londrina, como se viu na análise de Cernev, tem uma forte conexão com as iniciativas ligadas ao liberalismo, onde se destaca a preocupação do bemestar da comunidade como garantia do desenvolvimento regional, uma tradição trazida pela colonização inglesa e suas ações coletivas em prol de seus empreendimentos.

A busca por soluções não envolve apenas o indivíduo mas impõe a reflexão que envolve a sociedade como um todo dentro de um amplo contexto liberal, onde o território é campo de uma constante afirmação da população que com ele interage, participando de forma pró-ativa com seus recursos endógenos.

Esta atitude caracteriza Londrina como território da liberdade política, tendo seu desenvolvimento fundamentado em recursos financeiros privados, o que levou a região a não depender do Governo do Estado do Paraná de forma prioritária. Isto fez com que seus cidadãos não esperassem por soluções vindas de um paternalismo estatal, encontrando formas inovadoras de gestão dos interesses coletivos.

A participação voluntária da sociedade viabilizou para a cidade a criação de uma série de infra-estruturas autônomas que foram vitais para suas atividades produtivas e seu conseqüente crescimento econômico, destacam-se, entre as iniciativas comunitárias, os seguintes empreendimentos:

1. Empresa de Energia Elétrica;

2. Serviço de Água e Esgoto;

3. Serviço de Comunicações Telefônicas;

4. Emissora de Televisão;

5. Terminal Rodoviário. 


\section{Desenvolvimento Industrial Descentralizado}

$\mathrm{Na}$ década de 90, Londrina, após uma série de bem sucedidas iniciativas para atrair investimentos, externos e locais, especialmente na área imobiliária, começou a enfrentar uma crise de proporções significativas para suas atividades econômicas urbanas.

Novamente a comunidade precisou criar saídas para o impasse do seu desenvolvimento urbano. Empresários de um lado refletiam sobre as condições que impediam o pleno crescimento do potencial econômico de Londrina e de outro o meio acadêmico colocava em discussão tendências internacionais de valorização do conhecimento como apoio para a geração de emprego e renda, através de impulsores da "Nova Economia", como a inovação tecnológica.

Do âmbito empresarial a visão era de um estímulo à atração de novas indústrias, o que, acreditavam os empresários, seria possível através de um diagnóstico das deficiências e vantagens da região para se alcançar estes objetivos, e elaboração de um plano estratégico para a industrialização de Londrina. Esta idéia veio a se concretizar com o Plano de Desenvolvimento Industrial de Londrina - PDI, elaborado pela empresa internacional Andersen Consulting em 1995.

Da academia veio a proposta da criação em Londrina de um pólo tecnológico como uma forma da região superar gargalos para a retomada do desenvolvimento econômico local. Organizada em uma associação para o desenvolvimento tecnológico, criada em 1993, a comunidade universitária, aliada a representantes do setor público local, estadual e federal, e do setor empresarial, depois de passar por uma série de discussões, seminários, estudos e pesquisas, afinal, em 1999, foi aprovada a elaboração de um plano estratégico de desenvolvimento tecnológico da região, em uma tentativa para institucionalizar a Tecnópolis de Londrina, idéia lançada em 1998.

Inicialmente, neste estudo será abordado o Plano de Desenvolvimento Industrial de Londrina - PDI, e, a seguir, o projeto Londrina Tecnópolis, analisando-se a inserção neste projeto de considerações extraídas do primeiro, procurando avaliar a capacidade de interação entre as duas iniciativas da comunidade londrinense. 
III. Desenvolvimento Industrial Descentralizado

\subsection{Plano de Desenvolvimento Industrial de Londrina}

\subsubsection{Concepção}

A partir de uma percepção de políticos e empresários locais de que havia um ineficiente aproveitamento do potencial de desenvolvimento de Londrina, a Prefeitura do Município e a Associação Comercial se uniram e contrataram, em 1994, a empresa Andersen Consulting com o objetivo de desenvolver um projeto voltado para criar uma base industrial a altura das condições sócio-econômicas da cidade.

“O Modelo de Desenvolvimento Industrial de Londrina norteará a obtenção de uma base industrial articulada eficiente, integrada e diversificada. Trata-se de um conjunto de conceitos que abrange a determinação dos segmentos industriais que devem ser desenvolvidos preferencialmente, assim como os atributos que as indústrias deverão ter.

No âmbito deste trabalho, a viabilização desse modelo depende da formulação de uma série de ações estratégicas, que deverão conduzir a cidade da situação desfavorável em que se encontra para o efetivo desenvolvimento industrial. São três os tipos de ações estratégicas passíveis de serem adotadas, conforme o diagrama a seguir"4.

Figura 2 - Ações Estratégicas para o Modelo de Desenvolvimento Industrial

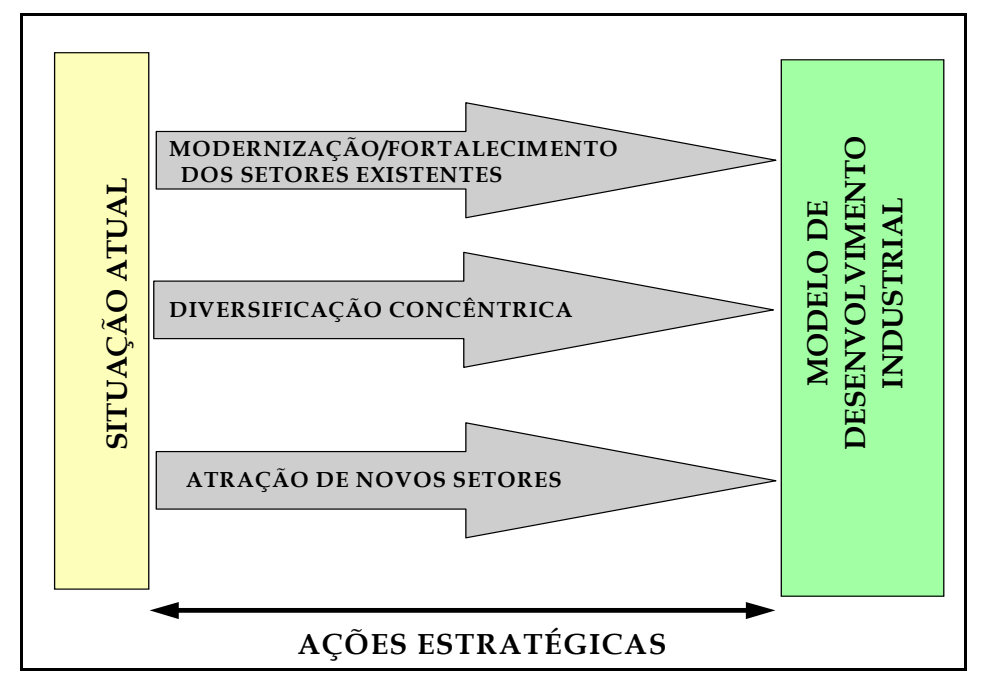

Fonte: PDI, Andersen Consulting, 1995.

Assim, o modelo de desenvolvimento industrial, na verdade, um projeto de industrialização, iria se constituir de um Plano Estratégico que 


\section{Desenvolvimento Industrial Descentralizado}

determinaria ações a partir de um diagnóstico que reconhecesse potencialidades e deficiências da cidade dentro de determinados setores industriais de interesse para desenvolvimento da economia local.

Uma avaliação da atratividade dos diferentes setores industriais considerados e do grau de adequação da estrutura urbana a cada um deles deveria permitir fundamentar um Plano de Marketing para atrair novas indústrias para a cidade, dentro do perfil determinado por este diagnóstico, e um Plano de Ações para melhorar o grau de adequação da estrutura urbana para receber certos setores de interesse.

\subsubsection{Diagnóstico}

Duas metodologias, nesta primeira etapa do Plano Estratégico, foram aplicadas para realizar o diagnóstico da cidade:

1. quando o setor enfocado já possuía significativa atuação na economia local; e

2. quando o setor era atraente, porém não existia na cidade.

\subsubsection{Setores Atuais}

O estudo detectou dois setores importante entre as indústrias existentes: o de alimentos e o têxtil e de confecções. O diagnóstico realizado para o setor têxtil e de confecções, por exemplo, se constituiu de:

- Análise Externa: com a definição do grau de atratividade das indústrias de fiação e tecelagem relacionando-as com as matérias primas utilizadas na industrialização. A abordagem é descritiva com análise de tendências globais de produção, consumo e comércio de produtos têxteis acabados.

- Análise Interna: através de uma Matriz de Competitividade da indústria local, sendo esta Matriz composta dos seguintes fatores: Estrutura de Custos, Recursos Financeiros, Qualidade do Produto, Mercado, Inovação Tecnológica, Qualificação dos Recursos Humanos, Ambientes Sócio-Trabalhistas, Pesquisa e Desenvolvimento e Gestão Empresarial. 
III. Desenvolvimento Industrial Descentralizado

A tabela a seguir mostra a aplicação desses conceitos na definição da competitividade da indústria local de confecção.

\begin{tabular}{|c|}
\hline Quadro 14 \\
\hline $\begin{array}{c}\text { Atributos para a Competitividade da Indústria } \\
\text { de Confecção em Londrina }\end{array}$ \\
\hline
\end{tabular}

\begin{tabular}{|l|c|c|c|}
\hline Fator & Importância & Peso & Indicador \\
\hline ESTRUTURA DE CUSTOS & ALTA & 3 & 2.1 \\
\hline Transporte de Matéria Prima & MÉDIA & 2 & 1.0 \\
\hline Custo de Mão-de-Obra & ALTA & 3 & 4.0 \\
\hline Custo da Matéria Prima & ALTA & 3 & 2.0 \\
\hline Utilização da Capacidade Instalada & ALTA & 3 & 1.0 \\
\hline Custos Financeiros & ALTA & 3 & 2.0 \\
\hline RECURSOS FINANCEIROS & MÉDIA & 2 & 1.5 \\
\hline Capacidade de Autofinanciamento & MÉDIA & 2 & 1.0 \\
\hline Acesso a Operações de Empréstimos & MÉDIA & 2 & 2.0 \\
\hline QUALIDADE & ALTA & 3 & 3.0 \\
\hline MERCADO & ALTA & 3 & 2.0 \\
\hline Distribuição/Comercialização & ALTA & 3 & 2.0 \\
\hline Promoção/Publicidade & ALTA & 3 & 2.0 \\
\hline Preço do Produto & 0 & 0 & 0.0 \\
\hline INOVAÇÃO TECNOLÓGICA & MÉDIA & 2 & 2.6 \\
\hline Metodologias de Produtividade/Qualidade & ALTA & 3 & 3.0 \\
\hline Inovaçáo dos Equipamentos & MÉDIA & 2 & 2.0 \\
\hline QUALIFICAÇÃO DOS REC. HUMANOS & ALTA & 3 & 2.3 \\
\hline Índice de Rotatividade & MÉDIA & 2 & 3.0 \\
\hline Qualificação da Mão-de-Obra & ALTA & 3 & 2.0 \\
\hline Treinamento & ALTA & 3 & 2.0 \\
\hline AMBIENTE SÓCIO-TRABALHISTA & MÉDIA & 2 & 4.5 \\
\hline Relacionamento com Sindicatos & MÉDIA & 2 & 4.0 \\
\hline Ocorrência de Greves & MÉDIA & 2 & 5.0 \\
\hline PESQUISA E DESENVOLVIMENTO & MÉDIA & 2 & 1.6 \\
\hline Relacionamento com Centros de Pesquisa & MÉDIA & 2 & 1.0 \\
\hline Investimentos em P\&D & MÉDIA & 2 & 1.0 \\
\hline Parceria no Desenvolvimento Tecnológico & ALTA & 3 & 2.0 \\
\hline Instituições para Compartilhar Tecnologias & MÉDIA & 2 & 2.0 \\
\hline GESTÃO EMPRESARIAL & ALTA & 3 & 3.0 \\
\hline Qualificação dos Executivos & ALTA & 3 & 3.0 \\
\hline Profissionalização da Gestão & 0 & 0 & 0.0 \\
\hline INDICADOR GLOBAL & 2.5 & & \\
\hline
\end{tabular}

Fonte: PDI, Andersen Consulting, 1995. 


\section{Desenvolvimento Industrial Descentralizado}

\subsubsection{Novos Setores}

Diferentes considerações foram realizadas para identificar setores industriais que, embora apresentassem um grande potencial de desenvolvimento dentro da conjuntura econômica esperada para os anos subseqüentes ao plano, não se encontravam em atividade na economia do município londrinense.

O diagnóstico foi estabelecido após:

- Análise da Adequação dos Setores: identificação do potencial de diversos setores industriais capazes de promover mudanças positivas na estrutura econômica da cidade.

- Análise de Atratividade dos Setores: avaliação do atrativo das diversas atividades industriais em termos de, por exemplo, valor agregado, ciclo de vida do mercado, taxa de crescimento, número de empregos gerados.

- Análise de Adequação da Estrutura Urbana: a análise da adequação da estrutura urbana sócio-econômica, cultural e física para receber determinados empreendimentos industriais caracterizados pelas suas necessidades quanto ao mercado de trabalho, acesso a clientes e fornecedores, necessidades de infraestruturas e serviços produtivos, comunicações e transportes, acesso a pesquisa e desenvolvimento, disponibilidade de recursos financeiros e papel normativo e fiscal.

\section{a. Análise da Adequação dos Setores}

A seleção dos setores com maior interesse potencial foi efetuada após análise dos seguintes critérios: capacidade de difusão de competitividade a outros setores produtivos, em função de seu caráter de indústria fornecedora de insumos, capacidade de difusão de competitividade pela sua configuração como setor fornecedor de bens de capital e presença atual das indústrias de Londrina.

Os setores escolhidos foram: Automação Industrial, Máquinas e Equipamentos, Móveis, Autopeças, Produtos Farmacêuticos, Equipamentos Médico-Hospitalares, Materiais de Construção, Eletrodomésticos e Bens 
III. Desenvolvimento Industrial Descentralizado

Eletrônicos de Consumo, Embalagens, Telecomunicações, Química, Indústrias de Reciclagem e Bebidas.

\section{b. Análise de Atratividade dos Setores}

Esta análise foi realizada com fundamentos adaptados de planejamento estratégico usualmente aplicado no setor privado, quando se verifica a oportunidade de negócio para a tomada de decisões. Determinou-se, no caso de planejamento estratégico da cidade de Londrina, quão oportuna para a comunidade seria a atração do setor industrial, ou seja, qual seria o grau de atratividade que o setor exerce sobre a cidade.

Para avaliação da atratividade dos setores, os quais foram determinados pela Análise da Adequação dos Setores, as variáveis utilizadas foram:

- Estrutura do Setor e Perspectiva de Crescimento

- Nível de Geração de Emprego

- Valor Agregado

- Possibilidade de Substituição de Importações

- Complementaridade com a Base Industrial Existente

- Dinamismo no comércio Exterior

- Prestígio para a Cidade

- Conteúdo Tecnológico

- Elemento Coadjuvante na Estrutura Sócio-Econômica da Cidade

Para analisar a atratividade para cada um dos setores foram estabelecidos quadros de avaliação em medidas qualitativas conforme o desempenho da variável para o setor enfocado, como se vê no quadro a seguir. 


\begin{tabular}{|c|c|}
\hline \multicolumn{2}{|c|}{ Quadro 15} \\
\hline \multicolumn{2}{|c|}{$\begin{array}{l}\text { Análise da Atratividade dos Diferentes Setores Industriais } \\
\text { para a Comunidade de Londrina }\end{array}$} \\
\hline Critério de Atratividade & Avaliação do Setor Industrial \\
\hline $\begin{array}{l}\text { Estrutura do Setor e Perspectiva de } \\
\text { Crescimento }\end{array}$ & $\begin{array}{l}1 \text { = em declínio, pouco dinâmico e com } \\
\text { escassas possibilidades de crescimento. } \\
5 \text { = em fase de introdução ou expansão com } \\
\text { grandes possibilidades de crescimento. }\end{array}$ \\
\hline Nível de Geração de Emprego & $\begin{array}{l}1 \text { = efeito muito reduzido na geração de } \\
\text { emprego, ou mão-de-obra pouco } \\
\text { qualificada } \\
5=\text { indústria intensiva de mão-de-obra, ou } \\
\text { mão-de-obra muito especializada }\end{array}$ \\
\hline Valor Agregado & $\begin{array}{l}1 \text { = baixo valor de transformação industrial } \\
5 \text { = alto índice de valor agregado e geração } \\
\text { de riqueza }\end{array}$ \\
\hline $\begin{array}{l}\text { Possibilidades de Substituições de } \\
\text { Importações }\end{array}$ & $\begin{array}{l}1 \text { = escasso volume de importações ou } \\
\text { reduzida capacidade de substituição de } \\
\text { importações existentes } \\
5 \text { = capacidade de substituição de um } \\
\text { grande volume de importações com a } \\
\text { produção de novas empresas } \\
\text { nacionais/locais }\end{array}$ \\
\hline $\begin{array}{l}\text { Complementaridade com a Base } \\
\text { Industrial Existente }\end{array}$ & $\begin{array}{l}1=\text { independente da atividade industrial e } \\
\text { econômica local } \\
5=\text { complementaridade total com o tecido } \\
\text { industrial e econômico atual e de sinergias }\end{array}$ \\
\hline Dinamismo no Comércio Exterior & $\begin{array}{l}1=\text { escassa presença internacional } \\
5=\text { alto dinamismo no comércio exterior }\end{array}$ \\
\hline Prestígio para a Cidade & $\begin{array}{l}1 \text { = efeito negativo para o prestígio da } \\
\text { cidade } \\
5=\text { elevado impacto na geração de prestígio }\end{array}$ \\
\hline Conteúdo Tecnológico & $\begin{array}{l}1 \text { = baixo grau de inovação tecnológica } \\
5=\text { alto grau de inovação tecnológica }\end{array}$ \\
\hline $\begin{array}{l}\text { Elemento Coadjuvante na Estrutura } \\
\text { Sócio-Econômica }\end{array}$ & $\begin{array}{l}1 \text { = reduzida relevância como impulsor } \\
5=\text { elevado grau de desenvolvimento } \\
\text { induzindo o resto da estrutura econômica } \\
\text { local }\end{array}$ \\
\hline
\end{tabular}

Fonte: PDI, Andersen Consulting, 1995.

A tabela anterior é complementada por uma outra que mostra os critérios de atratividade, os graus de importância e os conceitos para a escala de 
III. Desenvolvimento Industrial Descentralizado

avaliação aplicados para a seleção dos setores objetos de análise, discriminados na Análise de Adequação dos Setores.

Esta tabela reflete o perfil industrial desejado pela comunidade londrinense e foi fixada após reflexões com base em um consenso entre o Comitê Executivo do Projeto e a Equipe Técnica da Andersen Consulting. O quadro a seguir mostra a sua configuração da atratividade industrial:

\begin{tabular}{|c|c|}
\hline \multicolumn{2}{|l|}{ Quadro 16} \\
\hline \multicolumn{2}{|c|}{$\begin{array}{l}\text { Atratividade de Setores Industriais } \\
\text { para a Comunidade de Londrina }\end{array}$} \\
\hline Critério de Atratividade & Grau de Importância \\
\hline Estrutura do Setor e Perspectiva de Crescimento & ALTO \\
\hline Nível de Geração de Emprego & MÉDIO \\
\hline Valor Agregado & ALTO \\
\hline Possibilidades de Substituições de Importações & BAIXO \\
\hline Complementaridade com a Base Industrial Existente & MÉDIO \\
\hline Dinamismo no Comércio Exterior & MÉDIO \\
\hline Prestígio para a Cidade & BAIXO \\
\hline Conteúdo Tecnológico & MÉDIO \\
\hline Elemento Coadjuvante na Estrutura Sócio-Econômica & MÉDIO \\
\hline
\end{tabular}

Fonte: PDI, Andersen Consulting, 1995.

Com base nesta tabela e na anterior foi efetuada uma avaliação ponderada, para analisar comparativamente os diversos setor industriais enfocados estabelecendo seu nível de atratividade.

\section{c. Análise de Adequação da Estrutura Urbana da Cidade}


III. Desenvolvimento Industrial Descentralizado

As considerações sobre os requisitos urbanos exigidos são feitas após avaliação de cada um dos diferentes elementos de apoio que podem influenciar a competitividade dos setores industriais enfocados individualmente.

Os requisitos da estrutura urbana, ou elementos de apoio, que foram analisados para avaliar a capacidade da cidade de Londrina atrair novas indústrias foram os seguintes:

- Mercado de Trabalho

- Acesso a Clientes e Fornecedores

- Necessidades de Infra-Estruturas e Serviços Produtivos

- Comunicações e Transportes

- Acesso a Pesquisa e Desenvolvimento

- Disponibilidade de Recursos Financeiros

- Papel Normativo e Fiscal

O quadro seguinte resume os critérios para a Análise de Adequação da Estrutura Urbana aplicada no PDI. 


\begin{tabular}{|c|c|c|}
\hline \multicolumn{3}{|c|}{ Quadro 17} \\
\hline \multicolumn{3}{|c|}{ Análise de Adequação da Estrutura Urbana da Cidade de Londrina } \\
\hline Critério de Atratividade & Grau de Importância & Avaliação \\
\hline Mercado de Trabalho & $\begin{array}{l}\text { De } 1=\text { pouco } \\
\text { importante } \\
\text { a } 5=\text { muito importante }\end{array}$ & \begin{tabular}{|l} 
De $1=$ notável desajuste \\
entre a oferta de recursos \\
humanos da cidade e a \\
demanda da indústria. \\
a $5=$ mercado local de \\
recursos humanos que \\
satisfaça as necessidades da \\
indústria local. \\
\end{tabular} \\
\hline $\begin{array}{l}\text { Acesso a Clientes e } \\
\text { Fornecedores }\end{array}$ & $\begin{array}{l}\text { De } 1=\text { pouco } \\
\text { importante } \\
\text { a } 5=\text { muito importante }\end{array}$ & $\begin{array}{l}\text { De 1 = localização relativa } \\
\text { aos consumidores e } \\
\text { fornecedores implica em } \\
\text { notável desvantagem } \\
\text { comparativa. } \\
\text { a } 5 \text { = proximidade ideal. } \\
\text { Implica em menores custos } \\
\text { de transportes ou estrutura } \\
\text { produtiva mais flexível. } \\
\end{array}$ \\
\hline $\begin{array}{l}\text { Necessidades de Infra- } \\
\text { Estruturas e Serviços } \\
\text { Produtivos }\end{array}$ & $\begin{array}{l}\text { De } 1=\text { pouco } \\
\text { importante } \\
\text { a } 5=\text { muito importante }\end{array}$ & $\begin{array}{l}\text { De } 1=\text { notáveis } \\
\text { insuficiências. } \\
\text { a } 5=\text { muito boas infra- } \\
\text { estruturas urbanas e oferta de } \\
\text { serviços. }\end{array}$ \\
\hline $\begin{array}{l}\text { Comunicações e } \\
\text { Transportes }\end{array}$ & $\begin{array}{l}\text { De } 1=\text { pouco } \\
\text { importante } \\
\text { a } 5=\text { muito importante }\end{array}$ & $\begin{array}{l}\text { De } 1=\text { rede de comunicações } \\
\text { insuficiente. } \\
\text { a } 5=\text { boas conexões e } \\
\text { serviços de transportes. }\end{array}$ \\
\hline $\begin{array}{l}\text { Acesso a Pesquisa e } \\
\text { Desenvolvimento }\end{array}$ & $\begin{array}{l}\text { De } 1=\text { pouco } \\
\text { importante } \\
\text { a } 5=\text { muito importante }\end{array}$ & $\begin{array}{l}\text { De } 1=\text { inexiste centro de } \\
\text { pesquisa. } \\
\text { a } 5=\text { presença de centros } \\
\text { líderes em pesquisa. Cidade } \\
\text { líder em tecnologia. }\end{array}$ \\
\hline \begin{tabular}{|l|} 
Disponibilidade de \\
Recursos Financeiros
\end{tabular} & $\begin{array}{l}\text { De } 1=\text { pouco } \\
\text { importante } \\
\text { a } 5=\text { muito importante }\end{array}$ & $\begin{array}{l}\text { De } 1=\text { escasso } \\
\text { desenvolvimento do mercado } \\
\text { de serviços financeiros. } \\
\text { a } 5 \text { = centro financeiro } \\
\text { desenvolvido para as } \\
\text { necessidades do setor. }\end{array}$ \\
\hline Papel Normativo e Fiscal & $\begin{array}{l}\text { De } 1=\text { pouco } \\
\text { importante } \\
\text { a } 5=\text { muito importante }\end{array}$ & $\begin{array}{l}\text { De } 1=\text { papel normativo e } \\
\text { fiscal inadequado. } \\
\text { a } 5=\text { papel normativo e } \\
\text { fiscal potencializador para o } \\
\text { investimento industrial. }\end{array}$ \\
\hline
\end{tabular}

Fonte: PDI, Andersen Consulting, 1995. 


\section{Desenvolvimento Industrial Descentralizado}

\subsubsection{Setores para Competitividade de Londrina}

Com a classificação obtida através da avaliação da atratividade dos diferentes setores industriais considerados e do grau de adequação da estrutura urbana de Londrina a cada um deles, os resultados da análise foram representados em uma matriz de Atratividade versus Adequação da Estrutura Urbana, os pontos que representariam os setores industriais ficaram dispostos em quatro quadrantes diferentes, mostrando os posicionamentos dos setores.

Quadrante A: os setores que apresentavam alto grau de atratividade e que encontravam uma adequada estrutura urbana com os elementos de apoio necessários para sua implementação.

Quadrante B: os setores industriais com alto grau de atratividade que não estavam encontrando a adequada estrutura urbana para suas atividades na cidade.

Quadrante C: os setores que possuíam baixo nível de atratividade e inadequada estrutura urbana para sua implantação.

Quadrante D: os setores que apresentavam baixo grau de atratividade mas encontravam uma adequação da estrutura urbana para os necessários elementos de apoio para suas atividades em Londrina.

Este análise matricial deveria indicar uma estratégia a ser adotada para atração de indústrias, a qual iria fundamentar o Plano de Marketing, próximo passo do Plano de Desenvolvimento Industrial de Londrina. O planejamento de marketing seria, então, desenvolvido com uma concentração de esforços da comunidade, principalmente, para atingir os setores estabelecidos pelo Quadrante A. Os setores incluídos no Quadrante B passariam a ser objeto de uma Formulação de Adequação por parte das lideranças da cidade para que se altere o status dos elementos de apoio, tais como criação de centros de pesquisa, cursos de graduação e pós-graduação, etc. Os setores dos Quadrantes C e D seriam objeto de um objetivo secundário no Plano de Marketing.

Os resultados da estruturação desta matriz estão na figura seguinte. 
III. Desenvolvimento Industrial Descentralizado

Atratividade Industrial

versus

\section{Adequação da Estrutura Urbana}

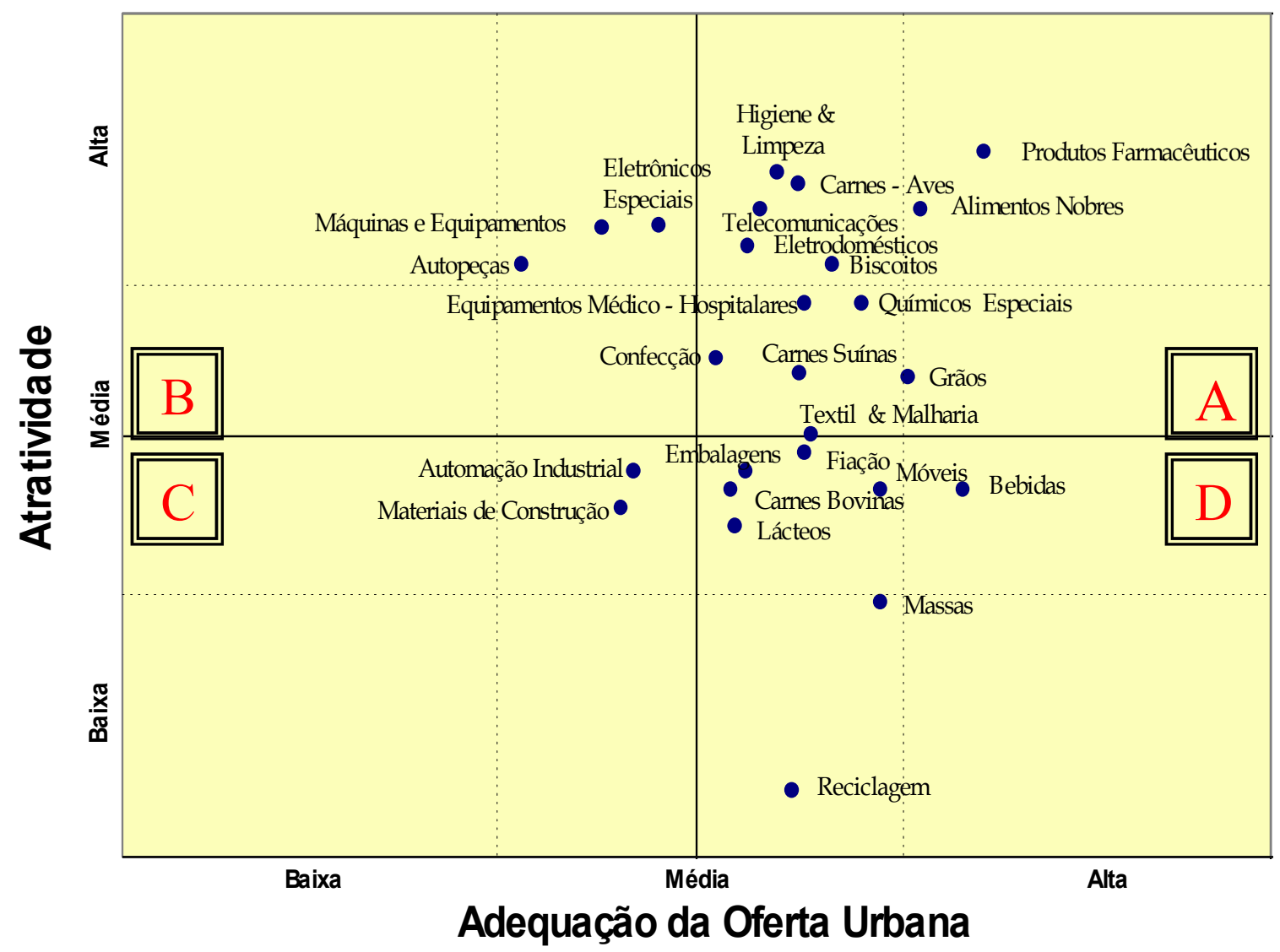

Fonte: Andersen Consulting (1995)

\subsubsection{Modelo de Desenvolvimento Industrial de Londrina}

Baseando-se na definição da matriz de competitividade de Londrina, o PDI determinou quatro premissas estratégicas que necessitariam ser consideradas para a definição do Modelo de Desenvolvimento Industrial - MDI:

1. Qual fator privilegiar? Atratividade ou Adequação da Oferta Urbana?

2. Como direcionar os esforços? Foco ou diversificação dos setores?

3. Qual o volume de investimentos almejado?

4. Qual o porte das empresas que se quer atrair? 


\section{Desenvolvimento Industrial Descentralizado}

Foram então respondidas estas questões com a participação do Comitê Executivo do PDI:

Premissa 1 - $\mathrm{O}$ fator de atratividade possui vantagens sobre o fator de oferta urbana, no sentido de oferecer maior possibilidade de perenizar as indústrias da cidade. Sendo assim, os setores Fármaco-químico, Eletroeletrônico, Alimentos e Têxtil devem ser os escolhidos, pois foram considerados como de maior atratividade para a cidade de Londrina.

Premissa 2 - Tendo em vista que o trabalho que o PDI requer conta com recursos finitos, a construção do MDI requer a definição da parcela de recursos a alocar para definir o foco e/ou diversificação.

Premissa 3 - Objetiva-se alcançar um crescimento de 2 a 4\% a.a. acima do crescimento vegetativo, que no $10^{\circ}$ ano resultaria em um incremento de $12 \%$ a $47 \%$ na renda per capita da cidade.

Premissa 4 - A atração de indústrias médias apresenta a melhor combinação entre volumes de negócios e ambiente competitivo.

Desta maneira, o MDI proposto pela Andersen Consulting considerou que os esforços da comunidade deveriam ser orientados para:

1. Buscar de 2 a $4 \%$ acima do crescimento vegetativo do PIB londrinense;

2. Priorizar empresas médias para a atração de investimentos, sendo as empresas novas dos setores fármaco-químico (produtos farmacêuticos, higiene \& limpeza e químicos especiais), alimentos (biscoitos finos, grãos e alimentos nobres) e eletro-eletrônicos (eletrodomésticos, equipamentos médico-hospitalares, telecomunicações e eletrônicos especiais);

3. Iniciar ações de fortalecimento dos setores existentes, têxtil e de alimentos, principalmente, com sugestão para atração de empresas complementares;

4. Utilizar a capacidade de intervenção para melhorar a oferta urbana de Londrina.

Entre as ações sugeridas para a melhoria na oferta urbana: 


\section{Desenvolvimento Industrial Descentralizado}

- Disponibilização de solos industriais com infra-estrutura necessária à imediata instalação de indústrias;

- Fomento à construção da Perimetral Norte;

- Desenvolvimento de programas Empresa-Escola;

- Viabilização da formação de mão-de-obra técnica em linha com as necessidades das indústrias;

- Criação de núcleos de excelência junto às universidades locais em: Têxtil, Alimentos, Química, Farmácia, Telecomunicações, Eletro-Eletrônica e Mecânica;

- Fomento à criação do Teleporto;

- Fomento à criação do Porto-Seco.

Para o fortalecimento do setores existentes algumas das ações propostas foram:

- Atração de empresas complementares;

- Desenvolvimento de programas de parcerias, visando transferência de tecnologia e injeção de recursos financeiros;

- Fomento à criação de um centro de Pesquisa de Materiais para desenvolver novos tipos de materiais como febras sintéticas e artificiais;

- Potencialização do setor primário quanto à pesquisa e utilização de novas tecnologias (IAPAR, EMBRAPA e UEL) para aumentar a produtividade e qualidade dos insumos;

- Melhoramento da comunicação entre empresas, faculdades e tecnologias.

As ações para atração de investimentos serão pró-ativas, buscando um contato maior com o investidor, devendo contar o PDI com instrumentos capazes de dar suporte a estas ações. Algumas das ações determinadas pelo plano foram:

- Apresentações "ad hoc" a empresas;

- Marketing direto;

- Publicidade em meios especializados; 
III. Desenvolvimento Industrial Descentralizado

- Kit do investidor - ferramentas para análise;

- Escritórios de representação;

- Promoção de eventos;

- Postura pró-ativa.

Os instrumentos para implementá-las sugeridos foram:

- Câmaras de Comércio;

- Hunters de companhias;

- Contratação de empresas especializadas;

- Programas de cooperação internacional;

- Parcerias com consultorias;

- Criação de uma agência de desenvolvimento.

A criação da agência de desenvolvimento deveria atuar como interlocutor único, facilitando o acesso aos distintos órgãos e outras entidades, que seriam:

- Prefeitura municipal;

- Governo estadual;

- BNDES;

- Associação comercial;

- SERCOMTEL;

- Universidades;

- SANEPAR;

- COPEL;

- ADETEC;

- Sociedade Rural.

6.4.4 Fatores Críticos para o Sucesso do PDI 
III. Desenvolvimento Industrial Descentralizado

O plano ainda apresentava recomendações para garantir a implantação em Londrina, considerados como fatores críticos para o sucesso do PDI, eram:

1. Comprometimento e suporte da comunidade;

2. Apoio público em todos os órgãos de representação;

3. Senso de urgência para o início do PDI:

- Ambiente cada vez mais competitivo;

- Grandes oportunidades aparecendo diariamente no mercado.

4. Iniciar a curto prazo as ações capazes de:

- Criar alicerces para a aplicação do plano de atração (agência);

- Buscar fontes de recursos para sustentação;

- Criar rede de contatos necessários para divulgação do PDI;

- Garantir a perenidade do PDI considerando os desafios do calendário político de 1996.

\subsubsection{Situação Atual do PDI}


III. Desenvolvimento Industrial Descentralizado

A implementação do PDI acabou ficando no âmbito da autarquia municipal Companhia de Desenvolvimento de Londrina - CODEL, embora fosse sugestão da empresa que elaborou o plano que fosse criada uma agência de desenvolvimento autônoma, sem vínculo político partidário de forma que seria garantida a perenização do PDI na comunidade. Entretanto isto se mostrou inviável diante dos recursos a serem mobilizados para implementar o plano que vieram exclusivamente do setor público, que dessa maneira passou a gerir o PDI de acordo com sua visão.

A principal ação implementada pelo comitê executivo do $\mathrm{PDI}^{5}$, organizado dentro do circuito da Prefeitura Municipal, através da CODEL, órgão responsável pela política industrial de Londrina, desde o encerramento dos trabalhos da Andersen Consulting, foi a elaboração do projeto da Cidade Industrial de Londrina, ação prevista pelo plano que visava a disponibilização de solos industriais com infra-estrutura necessária à imediata instalação de novas indústrias atraídas para o município.

As demais ações ainda se encontram em processo de implementação, dependendo de recursos que não foram até agora previstos em orçamento da Prefeitura Municipal, dentre elas a criação da agência de desenvolvimento, considerada vital para a institucionalização do PDI na comunidade local e externa. 
III. Desenvolvimento Industrial Descentralizado

\subsection{Projeto Londrina Tecnópolis}

\subsubsection{Histórico}

O projeto da Tecnópolis de Londrina começou a se delinear em junho de 1993, quando, como conseqüência de um workshop sobre tecnologia promovido pela Universidade Estadual de Londrina - UEL, surgiu o movimento "Pró-Pólo Tecnológico".

Em outubro de 1993, este grupo de professores e pesquisadores da UEL criou a ADETEC (Associação do Desenvolvimento Tecnológico de Londrina) com objetivo de coordenar as ações necessárias para implementar o Pólo Tecnológico de acordo com a idéia lançada no workshop.

Com a participação de lideranças da comunidade política, empresarial e acadêmica de Londrina, a ADETEC determinou sua missão: "Recuperar o dinamismo econômico e o progresso social de Londrina e Norte do Paraná, gerando desenvolvimento com qualidade de vida" com o objetivo estratégico primordial: consolidar Londrina como Pólo Tecnológico do Norte do Paraná.

A ADETEC passou a realizar, então, diversas ações estratégicas para consolidar sua missão, destacando-se: criação dos cursos de graduação de Engenharia Elétrica e de mestrado em Ciência da Computação na UEL; pósgraduação em Engenharia de Software e de Telecomunicações; eventos que congregam a comunidade tecnológica de Londrina, como a Jornada Tecnológica; criação de prêmios de incentivo, como o Destaque Tecnológico; fundação de empresas de participação comunitária de capital de risco para empreendimentos de alta tecnologia como a LONDRITEC S.A., além de eventos, seminários, jornadas e encontros nacionais e internacionais perseguindo a meta exposta em sua missão.

Dessa maneira a associação desenvolveu o Núcleo Norte do Paraná do Programa Nacional de Software para Exportação (SOFTEX-NPR). Apoiado pelo CNPq, com investimentos anuais de $\mathrm{R} \$ 500$ mil, para a capacitação tecnológica e empresarial do segmento de software da região. Ao longo dos últimos anos, o SOFTEX-NPR vem buscando resultados, com experiências como: 


\section{Desenvolvimento Industrial Descentralizado}

- Softwares do Núcleo com distribuição na Europa e prospeção de distribuidores internacionais, através da empresa Mastersoft, de Milão, Itália;

- Escritório na Incubadora Tecnológica de Austin, capital do Texas;

- Intercâmbio com a Incubadora Internacional de Negócios - de San Jose, na Califórnia, EUA;

- Representação comercial, com escritório em São Paulo, na Av. Faria Lima, em parceria com as empresas Identech, Kaizen e Mastersoft;

- Exportações de software locais que de U\$ 10 mil em 1998 e alcançaram atingir U\$ 400 mil em 1999;

- Certificação, através do Grupo "Rumo a ISO 9000", de cinco empresas em 99; e um segundo grupo está sendo implantado;

- Participações do Núcleo NPR em 29 eventos nos EUA (Comdex), Europa (Cebit) e Argentina, entre outros no Brasil, para prospeção de negócios;

- Traduções, com profissionais qualificados, colocando-se tradutores (inglês e espanhol) à disposição das empresas;

- Recursos do $\mathrm{CNPq}$ destinados à capacitação tecnológica e empresarial para 17 projetos das empresas do Núcleo;

- Projeto Gênesis para fomentar novas empresas de software nas universidades, atualmente são dois grupos: o Genorp na UEL (Universidade Estadual de Londrina) e o Inlomar na UEM (Universidade Estadual de Maringá);

- Redução do Imposto Sobre Serviços (ISS) de 3\% para 1\%, pela Prefeitura Municipal de Londrina para empresas engajadas no SOFTEX.

Esta série de iniciativas permitiu criar uma massa crítica, capacitando a ADETEC e seus colaboradores para proporem um ambicioso programa de atividades tecnológicas e empresariais visando dar suporte à implantação do 
III. Desenvolvimento Industrial Descentralizado

projeto Londrina Tecnópolis, lançado durante o evento da Jornada Tecnológica de 1998.

\subsubsection{Justificativa do Projeto Londrina Tecnópolis}

O termo de compromisso do projeto Londrina Tecnópolis destacava:

1. A necessidade de elevar Londrina à condição de Região Classe Mundial;

2. Que o conceito de Tecnópolis, desenvolvido e adotado em diversas cidades e regiões Classe Mundial do planeta, tem sido um instrumento eficaz de desenvolvimento econômico e social, alicerçado no desenvolvimento tecnológico, preservando e aumentando a qualidade de vida;

3. Que a estruturação de uma cidade/região como Tecnópolis gera integração, sinergia e proatividade entre os diversos agentes do desenvolvimento, substituindo a dispersão de recursos, duplicidade de iniciativas e competição predatória entre parceiros por racionalização de custos, otimização de investimentos, aumento da competitividade, tudo visando um desenvolvimento de qualidade, sustentado tecnologicamente;

4. Que a região de Londrina já dispõe de diversas estruturas e iniciativas típicas de uma Tecnópolis, mas que faltam maior sinergia e unidade de ação entre essas estruturas, o que tem gerado dissociação entre oferta e demanda de serviços tecnológicos.

\subsubsection{Etapas do Projeto}

E, portanto, diante destes fatores estruturantes e conjunturais, as entidades envolvidas no trabalho da ADETEC, resolviam lançar o projeto Londrina Tecnópolis, que deveria se constituir das seguintes etapas iniciais:

- Constituição do Fórum Londrina Tecnópolis, composto por representantes das instituições que este subscrevem e outras, da cidade e região, que venham a ser convidadas, e que terá a finalidade de deliberar sobre toda a condução do projeto; 
III. Desenvolvimento Industrial Descentralizado

- Elaboração do "mapa tecnológico" da região, um completo levantamento abrangendo setores público, privado e de pesquisa/desenvolvimento, enfocando entre outros os seguintes aspectos:

1. Competências tecnológicas existentes e a situação das mesmas em relação ao estado da arte e da técnica nos respectivos setores;

2. Análise crítica do desenvolvimento tecnológico;

3. Identificação de gargalos tecnológicos;

4. Elaboração do projeto em si, com indicações de ações para otimizar as competências existentes, racionalizar custos, superar gargalos e projetar Londrina Tecnópolis em nível internacional no âmbito do desenvolvimento tecnológico.

\subsubsection{Competências Tecnológicas de Londrina}

Fundamentando-se na existência de duas correntes de pensamento a respeito de projetos de Tecnópolises: uma que vê "Tecnópolis" como inteiramente projetada, exigindo inclusive um novo espaço para instalação das estruturas de competências tecnológicas; e a outra que parte do pressuposto de que cidades que já possuem algumas competências tecnológicas, tais como: universidades com centros de tecnologia, institutos de pesquisa, escritórios de transferência de tecnologia, densidade de massa critica com índices acima da média, empresas de base tecnológica, entre outras, podem ser planejadas para se configurar uma "Tecnópolis", a ADETEC tem dirigido o projeto para Londrina dentro da segunda corrente, na qual:

“Os cientistas são pessoas humanas, gregários por natureza como os demais indivíduos de uma sociedade, e isolar pesquisadores cientistas do convívio social, significava não um avanço científico e tecnológico, mas um retrocesso na construção do conhecimento universal"’.

Assim, partindo do pressuposto de que Londrina possuía competências tecnológicas que podem ser organizadas e aliadas às ações de um planejamento de desenvolvimento científico e tecnológico, a cidade tem a base necessária para a estruturação de uma Tecnópolis. 
III. Desenvolvimento Industrial Descentralizado

A ADETEC identificou as competências tecnológicas nas seguintes estruturas locais:

- 02 universidades (UEL e UNOPAR), sendo uma pública estadual e uma particular, nas quais existem cursos de engenharia e correlatos, em áreas de tecnologia;

- 01 instituição de nível superior (CESULON) que também oferece cursos nas áreas de tecnologia (processamento de dados $\mathrm{e}$ correlatos);

- 02 institutos de pesquisa agropecuária (EMBRAPA e IAPAR), com histórias de sucesso no desenvolvimento de pesquisas em áreas afins, com importantes contribuições para o desenvolvimento tecnológico na produção agrícola;

- 03 escolas de nível médio (SENAI, IPOLON e CASTALDI) que oferecem cursos nas áreas de automação industrial e telecomunicações;

- 01 programa de desenvolvimento de novos empreendedores na área de informática (GENORP);

- 01 incubadora de empresas que apoia também empresas de base tecnológica (INCIL);

- 01 programa de desenvolvimento tecnológico na área de software (SOFTEX 2000);

- 01 programa de difusão tecnológica ( Disqtec UEL);

- 01 Laboratório de desenvolvimento e fabricação de medicamentos (UEL);

- 04 instituições de fomento e apoio ao desenvolvimento tecnológico (ADETEC, Programa Paraná Europa - PPE, ITEDES e FAPEAGRO);

- 02 Programas de apoio ao desenvolvimento tecnológico de micros e pequenas empresas (SEBRAETEC e PATME).

\subsubsection{Empresas com Potencial Tecnológico de Londrina}




\section{Desenvolvimento Industrial Descentralizado}

Há uma potencialidade de integração entre centros de pesquisa, universidades e empresas que têm base tecnológica e unidades produtivas em Londrina.

Segundo levantamentos da ADETEC esta integração deve garantir a implantação do projeto que será consolidada pela presença de grandes empresas que desenvolvem pesquisas e possuem laboratórios próprios para desenvolvimento de produtos e ensaios de qualidade, como a Cia. Cacique de Café Solúvel, CONFEPAR, Milenia e Atlas Vilares, embora a entidade já esteja reconhecendo a dificuldade para que isto aconteça.

Também, favorecendo o spin-off do pólo tecnológico, foi constatada um boa presença de empresas de pequeno e médio porte que desenvolvem pesquisas, tendo feito lançamentos de produtos inovadores, até mesmo em nível mundial (Indrel, Entelbra, Lactron, Spyktron, Spectro, Odonto-Lógica e ldentech, dentre outras).

Ainda há a presença de empresas de médio e pequeno porte que aplicam conhecimentos científicos e tecnológicos em produtos e processos (Rondopar, Reifor, Hussmann-Fast Frio, Flidromar, Hayama, Aoyama, Jabur Processamento, Selmi, Nishi, Krys Belt Pepilon, Exactus, Comsystem, Pentamax, Usitec, Conections, MXR, MSE, Ciclos, Vittúria, Alquiminas, Gotas Verdes, IDB, Natureen e Néctar, entre outras).

Além disso é notável a presença de empresas usuárias intensivas de conhecimento científico e tecnológico e de produtos de tecnologia avançada (Sercomtel e Global Telecom) potenciais parceiras para pesquisa e desenvolvimento.

\subsubsection{Mapeamento das Competências Tecnológicas}

A proposta inicial da ADETEC considerou os pressupostos acima, julgando necessário um mapeamento das competências tecnológicas do município de Londrina, o qual deverá ser previamente discutido com representantes de instituições de ensino e pesquisa, instituições de fomento e financiamento, empresas produtoras e usuárias de produtos e serviços tecnológicos, setor público nos níveis municipal, estadual e federal. 
III. Desenvolvimento Industrial Descentralizado

Os setores inicialmente escolhidos para este mapeamento tecnológicos foram:

(a) Grupo de Eletro-eletrônica

- Eletromecânica

- Eletroquímica

- Eletrotécnica

- Eletrônica

(b) Grupo de Informática

- Telecomunicações

- Software

- Automação microprocessada

(c) Grupo de Metal-mecânica

- Refrigeração

- Hidromecânica

- Pneumática

- Usinagem

(d) Grupo de Química

- Agroquímica

- Fármaco-quimico

- Química de alimentos

- Bioquímica

- Fitoterápicos

Pretendia, ainda, a ADETEC, dentro do projeto Tecnópolis de Londrina, estruturar ações de desenvolvimento das áreas potenciais já anteriormente identificadas pelo Plano de Desenvolvimento Industrial - PDI, cujo valor agregado, esteja diretamente ligado ao emprego de conhecimentos científicos e tecnológicos. 


\section{Desenvolvimento Industrial Descentralizado}

\subsubsection{Situação Atual do Projeto Londrina Tecnópolis}

No início de 2000 a gerência do projeto foi assumida pelo pesquisador Dr. Mauro Silva Ruiz, vindo do IPT. Com sua participação, sob a coordenação da ADETEC e com colaboradores da comunidade acadêmica, empresarial e de pesquisa, o plano de ação do projeto está sendo definido:

Primeiro, a proposta do projeto foi estendida a uma região compreendida pelas cidades de Cornélio Procópio, Jataizinho, Ibiporã, Cambé, Rolândia e Arapongas e buscará um ambiente de cooperação entre as universidades e empresas da região, capaz de remover gargalos tecnológicos e gerar inovações nos produtos e serviços produzidos no Norte do Paraná.

Segundo, aos segmentos selecionados anteriormente e agora denominados químicos e eletro-infocomunicação, foi acrescentado mais o de Alimentos, tendo em vista o potencial de industrialização de produtos da região e também por causa da estrutura produtiva já existente no Norte do Paraná, com oportunidade para a criação de um "cluster".

O cronograma do projeto prevê como trabalho inicial a elaboração de um "Plano Estratégico de Desenvolvimento Tecnológico" para a região, com aprovação deste plano para meados de novembro do corrente ano pelos parceiros e patrocinadores do projeto. A entrega final está prevista para dezembro, ainda neste ano.

\subsection{O PDI e o Projeto Londrina Tecnópolis}

As duas iniciativas, embora realizadas de forma independente, apontam alternativas para o desenvolvimento local de Londrina e região e, ainda que seja necessário compreendê-las como experiências singulares, há necessidade de integrá-las em uma visão única, evitando dispersão de esforços da comunidade para atingir os propósitos das iniciativas, que em essência são os mesmos: o aumento da competitividade da região de Londrina no cenário global.

A discussão deve se dar sob o estímulo da ambição intelectual maior da proposta do meio acadêmico, inserida no âmbito da iniciativa dos empresários, analisando sua capacidade de apoio ao objetivo estratégico de industrialização em 


\section{Desenvolvimento Industrial Descentralizado}

Londrina e a viabilidade deste contar com a idéia força do plano da associação: a estruturação na região de uma rede interinstitucional baseada tecnologicamente e inserida no meio produtivo regional.

A reflexão deveria se estender em até que ponto este ideário poderia desencadear a instituição de uma “Tecnópolis", como entendida pelos pesquisadores e baseada nas experiências mundiais correntes.

Primeiro, deve-se abordar o Plano de Desenvolvimento Industrial de Londrina - PDI, desenvolvido pela empresa Andersen Consulting e em implantação pela Companhia de Desenvolvimento de Londrina - CODEL na forma de um comitê executivo inserido na estrutura administrativa desta autarquia municipal.

A tomada de decisão no âmbito governamental local coloca em risco permanente o PDI, pois torna este processo incapaz de agregar concretamente lideranças comunitárias, empresárias e acadêmicas, acabando por dificultar o desenvolvimento industrial de Londrina, com a agilidade com o qual foi recomendado.

A agência de desenvolvimento, indicada pela Andersen Consulting para gerir o programa de trabalho, teria como objetivo atender a necessidade permanente de ajustes estratégicos no PDI, o que não é possível acontecer no âmbito municipal, burocrático por natureza, no qual se insere atualmente o plano.

A competência da implantação do processo deste tipo de planejamento exige o monitoramento constante de informações que interagem com a industrialização, são fatores da competitividade local, tais como: mudanças na condições locais de negócios ou de infra-estrutura, ambientais e outros eventos ou condições não previstos, mesmo no nível globalizado que irão apontar o posicionamento da cidade e a política local de industrialização mais adequada no horizonte do cenário prospectado.

O gerenciamento eficaz é uma ferramenta do processo de avaliação e o monitoramento da performance em um programa de desenvolvimento industrial, deve ser realizado regularmente a partir do plano de trabalho ${ }^{7}$. Este é o meio pelo qual o plano estratégico é implementado e os resultados atingidos são avaliados. 


\section{Desenvolvimento Industrial Descentralizado}

Desde que a organização de desenvolvimento do plano tenha claro o senso de para onde a comunidade quer e pode ir, é possível formular tarefas e ações específicas que levarão a organização e a comunidade naquela direção, o que não se consegue com o isolamento que o PDI tem se reservado ao escolher a atmosfera pública para sua gestão, o que dificulta a participação de segmentos importantes da sociedade e a direção mais importante para ela.

A atratividade industrial foi um fator determinante na construção do modelo de desenvolvimento industrial de Londrina, a atração de empresas para a cidade desejada pela comunidade seria baseada em nove critérios, obedecendo a uma ordenação preferencial de fatores pelo seu grau de importância:

Estrutura do Setor e Perspectiva de Crescimento - Alto

Valor Agregado - Alto

Complementaridade com a Base Industrial Existente - Médio

Dinamismo no Comércio Exterior - Médio

Elemento Coadjuvante na Estrutura Sócio-Econômica - Médio

Nível de Geração de Emprego - Médio

Conteúdo Tecnológico - Médio

Possibilidades de Substituições de Importações - Baixo

Prestígio para a Cidade - Baixo

Algumas posições seriam, evidentemente, revistas. Para exemplificar:

O critério Prestígio para a Cidade, que é ligado a uma promoção positiva da comunidade no nível nacional e internacional com atração de empresa de renome, foi considerado na elaboração do PDI como de grau de importância baixo, mas se mostra hoje com alto grau de importância. Isto se deve à projeção negativa que a cidade ganhou no corrente ano com constantes denúncias de corrupção na administração municipal divulgadas pela mídia nacional, a qual vem comprometendo a imagem da comunidade e a credibilidade da região. Este quadro desfavorável poderia se reverter com um empreendimento expressivo oriundo de investimentos externos, mostrando a confiança do meio empresarial nas instituições da região e na sociedade local. 
III. Desenvolvimento Industrial Descentralizado

O critério "Conteúdo Tecnológico" é outro que mereceria uma nova avaliação diante da iniciativa local da ADETEC que não é compatível com esta classificação, pois as ações estruturantes que a associação idealiza são voltadas a uma sinergia onde a tecnologia é fator determinante da estratégia, o que não condiz com o grau de importância média registrado pelo PDI.

O critério "Complementaridade com a Base Industrial Existente", a partir das considerações do projeto Londrina Tecnópolis que pretendem potencializar a competitividade da pequenas e médias empresas de base tecnológica, mostra-se divergente em seu grau de importância avaliado como médio se for considerada a possibilidade de uma estratégia unificada de desenvolvimento industrial.

Além disso, devem ser consideradas novas condições que foram criadas desde 1995 até o momento e abordar as implicações das transformações que o PDI precisa enfrentar. Primeiro, na economia local, com a chegada das primeiras grandes empresas na Cidade Industrial de Londrina, como a DixieToga, do setor de embalagens e da Atlas-Schindler, do setor mecânico, segmento de elevadores; segundo, no cenário global, onde vem se apostando em empresas inovadoras mais do que nas do setores tradicionais.

Tendo como forte componente a base tecnológica, os empreendimentos voltados para produtos aparentemente insensíveis à competição de custos, porém com ciclos-de-vida fortemente definidos, evoluindo do início da inovação para a maturação como produtos padronizados, se tornam crescentemente vulneráveis à competição de custos. Dessa maneira, suas estratégias logísticas, sensíveis a estruturas de custos locais, trazem novas premissas, relevadas na concepção do PDI.

Além das novas premissas, outras considerações devem ser realizadas, para que se possa identificar o PDI, de fato, como um plano de desenvolvimento de e para Londrina, incorporando uma visão endógena. Neste novo contexto, a performance da economia industrial deverá se basear em estratégias para os diferentes portes da empresas presentes na comunidade, mais do que para novas empresas. 


\section{Desenvolvimento Industrial Descentralizado}

Este desempenho da competitividade industrial local depende das relações de produção com os "fatores invisíveis" da comunidade, viáveis para elas e também para as novas empresas na região: qualidade da força de trabalho, ambiente empresarial-trabalhista e relações de cooperação com empresas locais, entre outros fatores, que o PDI deve compreender e assimilar nas estratégias de industrialização. Não se devendo esquecer que as regiões são mais do que orçamentos e negócios, são locais que abrangem pessoas, cultura, herança histórica, patrimônio físico e oportunidades para as empresas que chegam e para aquelas que há muito lutam por elas.

Vê-se a importância para o PDI de centrar os esforços para o desenvolvimento industrial local de empresas da região, usando para isso incentivos de fatores invisíveis como base para construir a economia local, relevando vantagens competitivas das localidades, ao mesmo tempo que investe no aprimoramento da produtividade da empresas regionais, onde é evidente a relevância da integração do PDI com o inovador projeto Londrina Tecnópolis, cuja base territorial é o espaço regional das atividades tecnológicas.

Ao escolher o desenvolvimento tecnológico como uma âncora de seu crescimento econômico, Londrina aponta em uma direção onde a "Nova Economia" tem um papel fundamental. Verdadeiro oásis do conhecimento e da cultura $^{8}$ no Brasil, esta cidade do interior do Paraná, mostra suas garras e desafia o obscuro lugar que a globalização parece estar reservando à nação brasileira.

Mas afinal poderá esta região, com sua gente aguerrida e organizada enfrentar o poderio de um mercado informacional que atravessa fronteiras em busca do mercado mundial e alcança valores para suas ações ${ }^{9}$ superiores ao de nossas maiores empresas, sem se perder em utópicas metas?

Talvez, desde que as iniciativas locais se integrem em busca de uma meta maior do que simples objetivos de curto prazo, embasando empreendimentos onde investimentos de capital se misturem com o capital social da comunidade, representado pela sua capacidade de agregar valores ao produto industrial na região produzido, seja pelo suporte à inovação tecnológica seja pela qualidade de seus recursos endógenos que irão garantir a atmosfera ideal para o surgimento de uma verdadeira Tecnópolis. 
III. Desenvolvimento Industrial Descentralizado

É crucial abordar questões de incentivos que são viáveis apenas no âmbito da política tecnológica e sempre lembrar a relativa força das iniciativas locais e regionais para alcançar o desenvolvimento tecnológico necessário para atrair empresas internacionais de alta tecnologia, e com isso incentivar novas bem-sucedidas empresas nacionais neste $\operatorname{setor}^{10}$, é daí que vem a importância do Plano Estratégico de Desenvolvimento Tecnológico, primeira ação do projeto Londrina Tecnópolis.

Reforçando o intuito do PDI em estimular as atividades industriais com qualidade de vida, a ADETEC tenta assegurar uma moderna e efetiva, infraestrutura tecnológica, a qual capacitaria Londrina para gerar e transformar conhecimento em inovação, que hoje já não é a base exclusivamente da indústria de alta tecnologia.

No desenvolvimento industrial local, o processo de transferência e desenvolvimento de novas tecnologias, vital para a competitividade e sobrevivência das empresas, só é viável quando a sociedade e a economia, incluindo o acesso ao capital de risco, forem intrinsecamente receptivos à inovação, oferecendo uma adequada infra-estrutura tecnológica onde se configuraria a região propícia à formação de uma Tecnópolis através de:

- Um sistema educacional que encoraje a criatividade e a busca do conhecimento científico e tecnológico;

- Uma rede de laboratórios capaz de trabalhar em conjunto para desenvolver e adquirir conhecimento a partir de informação que venha de fora;

- Uma estrutura para desenvolvimento e controle de qualidade dos produtos, dentro das normas internacionais;

- Recursos técnicos, como lojas de equipamentos e maquinários de precisão e computacionais;

- Uma estrutura industrial que irá sustentar uma produtiva “ecologia industrial", na qual pequenos fornecedores potencialmente inovadores e orientados tecnologicamente servem grandes empresas que têm acesso aos recursos e ao mercado; 


\section{Desenvolvimento Industrial Descentralizado}

- Instituições e programas que liguem pesquisadores e inventores a potenciais usuários do conhecimento que eles geram, tanto quanto aos investidores;

- Um sistema legal para proteger inovações tecnológicas, tanto as locais quanto as importadas;

- Um meio ambiente político econômico que encoraje a pesquisa, desenvolvimento e investimento em inovação;

- Uma rede de energia elétrica confiável com boa freqüência e controle de amplitude;

- Uma infra-estrutura de telecomunicações, comunicações e transporte adequada.

Diante da complexidade destas recomendações ${ }^{11}$, vê-se que para criar a atmosfera ideal de uma Tecnópolis em Londrina se impõe uma mobilização de recursos materiais e intelectuais que supera o âmbito local, repercutindo nas esferas de decisão do governo federal e estadual, estando também relacionadas a uma interação com as comunidades acadêmicas e empresariais nacionais e internacionais, onde estariam recursos financeiros capazes de assumir um projeto com esta envergadura.

Para se adequar este objetivo, ao lado da necessidade de uma revisão em suas premissas, o PDI deveria atuar sob o novo cenário das cadeias produtivas nacionais e internacionais, com uma análise do potencial de industrialização para toda a região sob influência da desejada Tecnópolis de Londrina, tarefas de fôlego que devem se fundamentar em estudos locais de profundidade, tendo como modelo o trabalho de indiscutível capacidade técnica apresentado pela Andersen Consulting, que é onde está o nível de qualidade a ser imprimida nos trabalhos a serem retomados.

Portanto, infelizmente, como se pode ver, embora se deva reconhecer e louvar o empreendedorismo da comunidade londrinense, que com a ordenação de sua base tecnológica busca a transformação da base produtiva regional, resultados significativos não podem ser esperados se não houver um 
III. Desenvolvimento Industrial Descentralizado

comprometimento político, com apoio da comunidade acadêmica, no nível estadual e federal.

Concluí-se que, mesmo contando com competência para implementar as ações locais necessárias, suficientemente comprovada com organizações que se mostram capazes de operacionalizá-las, como a ADETEC, e ainda fundamentadoas em bem elaborados planos estratégicos, que é o caso do PDI, se não houver um comprometimento do setor público em todas as suas instâncias, do local ao federal, muito pouco será alcançado para que de fato se possa considerar Londrina uma Tecnópolis. 
IV. Impacto da Globalização no Desenvolvimento Local

1. Introdução, 283

2. Sociedade de Risco, 285

2.1 A Modernização Reflexiva, 285

2.2 O Conceito de Risco Fabricado, 285

3. Catástrofe Urbana, 290

4. Sociedade em Rede, 292

5. Limites do Estado, 296

6. Espaço e Tempo, 299

7. Desenvolvimento sem Trabalho, 302 


\section{Introdução}

A rápida e crescente transformação da sociedade não vem permitindo uma abordagem mais do planejamento como um produto, mas sim como um processo. Com a globalização, ou seja a mundialização da economia, o que vem acontecendo em termos de mudanças que possam refletir nas cidades? Os resultados da transformação econômica global, não permitem estabelecer planos que não sejam passíveis de alteração a curto prazo. Assim, o que interessa, em termos de decisão, pública ou privada, política e/ou econômica, é o que acontece agora em nível global que interfira no desenvolvimento econômico local.

Porém é relevante sustentar que em desenvolvimento no nível local é primordial a qualidade de vida. Percebe-se ainda a inserção de um novo significado para esta qualidade a ser oferecida aos cidadãos, onde ao lado de todo um conjunto de oferta de infra-estrutura urbana, física e social, aliado ao bemestar da comunidade, ambiciona-se a capacidade de consumo da comunidade, reflexo da sustentabilidade de uma economia local.

Há uma ameaça permanente para a comunidade urbana no nível global, que independe de sua competitividade, pois está ligada aos fatores macro econômicos da economia emergente, que é o risco de começar a sua decadência econômica, física, social e ambiental e morrer no "sistema-mundo" .

Qual a importância destas considerações, onde, afinal, o que interessa é a discussão de um novo aspecto da economia internacional ${ }^{2}$ para o planejamento das atividades urbanas e regionais? Os urbanistas se dobram perante a constatação de que sem desenvolvimento econômico não há porque estruturar cidades. Para que serve o planejamento de um sistema viário para algo que não sobreviverá as alterações econômicas? Cidades podem morrer e não se pode afirmar que apenas as cidades pequenas morrerão.

Aqui voltam a se encontrar as lideranças fundamentais do locus urbano: o empresário e o político. De um lado o perfil do executivo privado, em busca do lucro e da rentabilidade do investimento realizado por fundos próprios, de parceiros e/ou sócios, rentabilidade agora, inserida em uma nova realidade econômica, onde se depende de um mercado globalizado, mercado este composto 
por consumidores ligados a uma consciência ambiental, esta não meramente utópica, mas, realística de sobrevivência da humanidade. De outro lado o perfil do executivo público, em busca da manutenção do poder político, fundamentado em estruturas democráticas, que viabilizem as operações de livre comércio, vital para a inserção da comunidade na relações econômicas globalizadas.

Assim, em se considerando a importância da compreensão deste emergente paradigma: a globalização para o desenvolvimento urbano e regional, pretende-se agora mostrar as diferentes abordagens que vem sendo discutidas por pesquisadores e teóricos em universidades e através dos meios de comunicação, por lideranças políticas, empresariais e comunitárias. 


\section{Sociedade de Risco}

\section{1 A Modernização Reflexiva}

Segundo Ulrich Beck, sociólogo, chefe do Instituto de Sociologia da Universidade de Munique e professor titular na London School of Economics, Sociedade de Risco é a contrapartida do fato de a sociedade industrial ter se tornado obsoleta. Os riscos gerados pelo próprio desenvolvimento capitalista lançam problemas, como o desemprego estrutural e o controle do meio ambiente, que as velhas instituições têm dificuldade de absorver.

Nesse clima de incertezas, cada vez mais distantes das instituições que davam segurança à sociedade industrial, como: família, classes sociais, etc., as pessoas sofrem uma individualização forçada, tendo que tomar decisões cotidianas que implicam risco pessoal. Por outro lado, isso causa o surgimento de uma multiplicidade de opiniões sobre os mais variados assuntos, o que caracteriza a Sociedade de Risco também como uma sociedade permanentemente autocrítica.

Isto fez com que surgisse a Modernização Reflexiva que se trata de um processo contínuo, imperceptível, quase autônomo de mudança que afeta as bases da sociedade industrial. Nada mais resta ao capitalismo senão transformar a sociedade industrial, forjada por ele próprio no passado.

As pessoas tendem a dar valor às antigas certezas da sociedade industrial, enquanto a realidade não cessa de alterar esses dados. Assim, há momentos em que os indivíduos têm que decidir entre uma convicção do passado, como a idéia de direitos trabalhistas rígidos, e a realidade transformada, como a "flexibilização" do trabalho. Esse confronto bilateral entre as convicções herdadas e as novas formas sociais confere a essa modernização o caráter "reflexivo".

Em função da crise ecológica aguda, houve uma ampliação do conceito de natureza, de modo que não se pode mais partir do princípio de que os recursos naturais para a produção estejam disponíveis para sempre, sem questionamento. Na verdade trata-se do contrário: com a destruição global da natureza, desenvolve-se um novo tipo de desafio para a Segunda Modernidade, que se denomina de a Sociedade de Risco. O problema principal da Segunda 
IV. Impacto da Globalização no Desenvolvimento Local

Modernidade é que todos os países, de uma maneira ou de outra, encontram-se simultaneamente diante desse desafio.

Sendo a Segunda Modernidade a simultaneidade do risco global, e os problemas que se traduzem nessa escala como: desagregação da sociedade do trabalho, universalização do desemprego, talvez a saída esteja como Ulrich Beck propõe como idéia central para transformar esse quadro: o "trabalho civil remunerado com dinheiro civil". Este modelo de trabalho significa tentar reconhecer todos os desempenhos criativos que se destinem à comunidade local, mas que se traduz também num espaço transnacional. É um "modelo de aproximação, uma plataforma que leve os homens a reencontrar sua criatividade e a produzir o novo, na escala de sua existência individual, passo a passo, no seu pequeno círculo, forjando as respostas a esse gigantesco desafio da Segunda Modernidade".

A seguir, estão dispostos os enfoques para a sociedade global do que seriam a Primeira Modernidade e a Segunda Modernidade. 


\begin{tabular}{|c|c|c|}
\hline \multicolumn{3}{|c|}{ Quadro 18} \\
\hline \multicolumn{3}{|c|}{ Enfoques da Primeira e da Segunda Modernidade } \\
\hline Enfoque & Primeira Modernidade & Segunda Modernidade \\
\hline Trabalho & $\begin{array}{l}\text { Sociedade do trabalho e do } \\
\text { sistema estandardizado de } \\
\text { pleno emprego do Welfare } \\
\text { State clássico. } \\
\text { Trabalho regulamentar dentro } \\
\text { de uma rede previdenciária. } \\
\text { Linearidade e localidade da } \\
\text { produção. }\end{array}$ & $\begin{array}{l}\text { Capitalismo sem trabalho. } \\
\text { Trabalho flexibilizado, } \\
\text { temporário. } \\
\text { Nômades do trabalho, } \\
\text { subjetividades fantasmas sem } \\
\text { seguridade social. } \\
\text { Pluralização do trabalho, na } \\
\text { eliminação da diferença entre } \\
\text { trabalho e não trabalho. }\end{array}$ \\
\hline Política & $\begin{array}{l}\text { Estado com soberania } \\
\text { econômico-territorial e árbitro } \\
\text { das desregulagens sistêmicas } \\
\text { e do jogo entre sindicatos e } \\
\text { capital. } \\
\text { Burocratização. }\end{array}$ & $\begin{array}{l}\text { Descentralização e pluralização } \\
\text { da arena política. } \\
\text { Novos atores não-territoriais } \\
\text { como capital e conglomerados } \\
\text { financeiros e empresariais. } \\
\text { O trabalho torna-se local e o } \\
\text { capital torna-se global. } \\
\end{array}$ \\
\hline Individualização & $\begin{array}{l}\text { Identidade tecida por classes } \\
\text { sociais, partidos e ideologias. }\end{array}$ & $\begin{array}{l}\text { Individualização além das } \\
\text { classes. } \\
\text { Pluralização dos estilos de vida, } \\
\text { dos afetos e personas sexuais. } \\
\text { Internalização do medo e da } \\
\text { angústia na presença dos riscos } \\
\text { globais. }\end{array}$ \\
\hline $\begin{array}{l}\text { Crises } \\
\text { ecológicas }\end{array}$ & $\begin{array}{l}\text { Exploração ilimitada da } \\
\text { natureza. } \\
\text { Banalização do conceito de } \\
\text { natureza pelos movimentos } \\
\text { ecológicos. } \\
\text { Distribuição desigual dos } \\
\text { riscos entre países ricos e } \\
\text { pobres. }\end{array}$ & $\begin{array}{l}\text { Trabalho sustentável. } \\
\text { Universalidade do risco: a } \\
\text { Sociedade de Risco não é a } \\
\text { sociedade revolucionária, mas } \\
\text { antes uma sociedade de } \\
\text { catástrofes na qual o Estado de } \\
\text { exceção tende a se tornar a } \\
\text { normalidade. } \\
\text { Ampliação do conceito de } \\
\text { natureza humana pela ciência. }\end{array}$ \\
\hline
\end{tabular}

Fonte: Folha de São Paulo, 23 de maio de 1999. 
IV. Impacto da Globalização no Desenvolvimento Local

\subsection{O Conceito de Risco Fabricado ${ }^{2}$}

Anthony Giddens, sociólogo, que dirige a London School of Economics e é conhecido internacionalmente, associado às idéias da Terceira $\mathrm{Via}^{3}$, acredita que a imprevisibilidade do mundo globalizado é um problema estrutural, em que não há escapatória à imprevisibilidade política e econômica do mundo atual.

Uma de suas idéias é a de manufactured risks, que sugere em seu bojo uma abordagem onde deve se relevar a distinção de que o risco existente na sociedade globalizada dos riscos existentes no passado é que, agora, não temos antecedentes históricos que nos digam o que fazer diante deles. São os riscos que advêm, por exemplo, de transformações genéticas ou climáticas, mas também de mudanças na estrutura da família, do casamento totalmente novas na história da civilização humana.

Globalização, risco, tradição, família e democracia são conceitos que devem estar no foco do pensamento. Como traduzir isso para a política ou como traduzir isso para os governos é um caminho que vai além de uma alternativa entre a tradicional social democracia e o neo liberalismo. Trata-se de dar uma resposta a todas essas mudanças onde a imprevisibilidade do mundo globalizado é um problema estrutural. Portanto, não é devido a uma simples conjuntura dos dias de hoje, de agora.

Não seria correto dizer que o mundo hoje é menos previsível do que era antes. A diferença agora é que enfrentamos situações de risco que outras gerações não tiveram que enfrentar. Esses novos riscos foram construídos ou pelo impacto da ciência e tecnologia nas nossas vidas, incluindo nossos corpos, ou por profundas mudanças na estrutura da sociedade.

A imprevisibilidade integra, para o bem ou para o mal, o mundo em que vivemos. Não há escapatória. É estrutural também no sentido de que uma reversão ao passado não é concebível. Para conviver com isso temos que encontrar um novo tipo de equilíbrio entre o risco e a segurança. Se se pensar em respostas políticas para esse problema, precisa-se pensar em governos ativos tentando dar segurança para as pessoas. Isso só vai acontecer se houver uma compreensão sofisticada das novas situações de incerteza. Se essa compreensão 
não existir, vai tentar-se adaptar a elas usando maneiras antigas, mas não vai funcionar.

Pois, afinal. o impacto da globalização cria cenários de "riscos fabricados" dos quais não temos experiências anteriores que nos orientem sobre o que fazer diante deles. Isso vai desde a vida pessoal, como as estruturas do casamento e da família - que estão mudando -, até a economia global e outras incertezas associadas à invasão da ciência e tecnologia em praticamente todos os aspectos do que fazemos até hoje. E do que iremos fazer aqui para frente. 


\section{Catástrofe Urbana ${ }^{1}$}

Paul Virílio, urbanista professor da Escola Superior de Arquitetura de Paris, membro fundador do Centro Interdisciplinar de Pesquisa da Paz e de Estudos Estratégicos, na Maison des Sciences de l'Homme questiona os benefícios da sociedade da informação e se preocupa quanto aos seus efeitos políticos. "Como, afinal, a globalização afetará as cidades? Que futuro reserva o planeta para a urbi? Diz-se que no século 21 haverá de se reinventar uma nova relação do homem com a Terra. A grande questão ecológica na verdade é a cidade. Não é a poluição do ar, da fauna, da flora, porém a construção da cidade dos homens, a democracia”.

Chegamos à desintegração da unidade familiar não no sentido moral, mas sim, enquanto unidade de reprodução. A grande metrópole minou a base da espécie humana, e nós agora vemos bandos de crianças que sobrevivem roubando os adultos. A cidade deixou de ser um lugar de socialização para se tornar um lugar de dessocialização.

Para que no próximo século a vida nas cidades melhore, é preciso que a política controle a técnica, porque, segundo a visão caótica de Paulo Virílio, “estamos às vésperas de uma grande revolução, que vai agravar os efeitos da revolução industrial: a revolução informacional que significará o desemprego em massa, o fim do trabalho e da força do homem e se o poder político não for capaz de controlar o desenvolvimento técnico dos autômatos, dos sistemas de produção, do mercado, iremos em direção a uma sociedade que terá duas velocidades: uma formada por uma elite que viverá em 'bunkers' e a outra uma formada pelos miseráveis que vão atacá-la. O problema hoje é controlar o desenvolvimento técnico. Nós entramos num período de desemprego em massa, que é estrutural e não conjetural".

Vê-se um futuro inexorável que é a metropolização, processo que era próprio do Terceiro Mundo. Para viverem nele, as pessoas se precipitavam em direção à capital, ao porto. Atualmente isso está acontecendo também com a Europa. Paris vai se tornando uma nebulosa, e a verdadeira questão é a do emprego. O problema que se coloca para o urbanista é o de saber onde ele deve construir alojamentos, quando já não existe trabalho permanente e o proletariado 
se dessedentariza. Onde construir alojamentos quando as pessoas circulam permanentemente?

Para intervir nesse processo, organizar a cidade, deve-se ter uma compreensão da técnica do transporte no século 19, que se caracteriza pela oposição entre a cidade e o campo e a da transmissão no século 20, que se caracteriza pela oposição entre o centro da cidade e a periferia. No século 21 , teremos a oposição entre os sedentários (que estão em casa em qualquer lugar, no trem, na rua, com o laptop, o celular), e os nômades (os que não estão em casa em lugar nenhum; o indivíduo que vive no carro à procura de um emprego, vai de um ponto a outro colhendo o que pode, sem apartamento, sem poder se casar).

Pode-se dizer que ser um urbanista significa dizer que se trabalha com a organização do espaço. Não é ser um construtor de cidades. A organização do território e da cidade, que é a forma política maior da história, é papel do urbanismo. Sobre a questão de existir, ou não, lugares e paisagens mais propícias a uma urbanização inteligente, este é um problema voltado para a circulação das populações. O essencial é a cidade estar situada num lugar onde o fluxo de gente é importante, porque ela é um ponto de encontro de pessoas, portanto pode ser um porto, um desfiladeiro ou uma confluência de rios.

Nesta abordagem conceitual sobre a cidade, como um fluxo de pessoas, ela deve ser como uma caixa de velocidade, ela pode ser vista como o rosto escondido da riqueza de uma civilização. A velocidade é, com os transportes coletivos e a iluminação noturna, um dos elementos principais da cidade. Foi a iluminação que fez de Paris a cidade-luz. Ela viabiliza a noite. A cidade sempre foi e sempre será, um lugar onde a gente se droga com a velocidade, com o álcool e agora com a Internet. 


\section{Sociedade em Rede ${ }^{1}$}

Discutir a globalização como uma Sociedade em Rede, como diz o sociólogo espanhol Manuel Castells, catedrático de planejamento urbano e regional na Universidade da Califórnia, deriva, em sua raiz, de uma questão fundamentalizada na era da informática, onde ocorrem três fenômenos iniciados nos anos 60 e 70 :

- Tecnologia da informação, que revolucionou a produção;

- Reestruturação e flexibilização do capitalismo e do estatismo; e

- Movimentos sociais como feminismo, ecologia e movimento do liberalismo sexual.

Estas transformações determinaram o desenvolvimento de um amplo espectro de assuntos interligados que vão da evolução da informática às transformações no trabalho e nos costumes sexuais, em todos os países do mundo. Desta forma, uma rede de relações entre sociedade e tecnologia vem ocorrendo, tendo como princípio o modelo de desenvolvimento da região, na Califórnia, conhecida como Silicon Valley, que teve uma importância fundamental na formação da revolução das tecnologias da informação.

Pode se dar conta, hoje, de que tudo mudava no Silicon Valley, não como conseqüência da tecnologia, mas devido a um meio tecnológico que convertia a capacidade de investigar e gerar conhecimento em força produtiva direta. Assim se percebeu que o poder de conexão, a conectividade entre os agentes que modelaram o Vale do Silício desde seu início, permitiu a instalação de uma verdadeira rede de desenvolvimento. A partir deste conceito, Manuel Castells afirma que é o grau de conexão de uma sociedade que indica hoje o seu nível de desenvolvimento.

O fenômeno da globalização estende seus conceitos em países antes fora do núcleo das decisões. Isto permite que o Brasil, a Índia e a Espanha, entre outros países, possam ser considerados como sociedades informacionais. Estas sociedades se caracterizam pelo fato da sociedade de informação ser uma sociedade em que as fontes de poder e riqueza dependem da capacidade de geração de conhecimento e processamento de informação. E tal capacidade 
depende da geração da interação entre recursos humanos, infra-estrutura tecnológica e inovação organizacional e estrutural. Nesse sentido todas as sociedades estão conectadas globalmente em redes de informação que condicionam toda a sua dinâmica. Mas há sociedades majoritariamente conectadas e outras em que somente um pólo dinâmico pertence a essas redes globais informacionais. Esta é a diferença entre desenvolvimento e irrelevância hoje.

Para o ritmo de crescimento da sociedade informacional continuar existindo há de se responder a uma questão básica: haverá suficiente demanda para absorver a produção de informação e entretenimento que cresce exponencialmente? Parece que tudo leva a crer que jamais haverá excesso de informação. Pois há defasagem entre a capacidade cultural das pessoas e a riqueza de informação disponível no mundo.

As pesquisas das empresas de multimídia demonstram que a ampliação da oferta de informação passa por novos conteúdos - educativos, culturais e políticos. A abertura ao mundo de toda a informação universal é uma possibilidade extraordinária que está mudando nossas vidas e nosso imaginário. Desde que o sistema educativo proporcione pessoas com capacidade para buscar, escolher e desfrutar, e aí reside o grande desafio para as gerações futuras, ainda está distante o dia que este mercado estará saturado.

O fenômeno urbano apresenta esta novidade: megacidades que se estendem no espaço e formam verdadeiras nebulosas urbanas, onde se integram campo e cidade, criatividade e problemas sociais ao mesmo tempo. Elas são os centros nervosos do sistema mundial. As cidades globais não são a questão. Toda grande cidade é algo global, em proporções diferentes. E é, até mesmo, também local ao mesmo tempo. A maioria dos bairros e pessoas vive vidas locais.

Nesse sentido, Bombaim e Lagos são globais também. Bombaim é um grande centro financeiro e de software em nível mundial, conectado com Londres e com Silicon Valley. Lagos está conectada financeiramente à indústria energética e também é um centro estratégico das máfias criminosas globais. Mas Londres, Bombaim, Lagos, Silicon Valley têm áreas locais desconectadas das redes globais, ainda que em proporções diferentes. Cerca de 90\% de Lagos está desconectada da rede global. No Silicon Valley essa proporção é de $10 \%$. 
IV. Impacto da Globalização no Desenvolvimento Local

Porém a cidade global não é concreta, ela é uma rede interterritorial ${ }^{2}$ de espaços locais conectados em uma rede global de capital e informação, onde estão Wall Street, a City de Londres, Ginza de Tóquio e a avenida Paulista, entre outros.

Identifica-se, ainda, o que Castells chama de "dual city": as cidades informacionais que concentram o pior e o melhor. Tanto com populações que estão conectadas à rede global quanto, e ao mesmo tempo, com populações desconectadas. Estas podem ser consideradas como "funcionalmente desnecessárias" nesse processo. Embora haja uma tendência de aumentar ou diminuir a desigualdade sócio-econômica dentro de uma cidade informacional pelo desejo de todos se conectarem.

Sabe-se que megacidades como São Paulo sempre serão os territórios que concentram maiores problemas sociais e ambientais. Mas também reúnem as maiores possibilidades de desenvolvimento, de criatividade e de vontade política para mudar as coisas. Pois, afinal, não são elas a fonte dos problemas, mas sim as redes globais de poder e riqueza que conectam o que dá lucro e desconectam o que não tem outro valor além de existir.

Não se sabe muito do futuro, mas se sabe do presente e da última década. Assim se sabe que em todo o mundo aumentou a exclusão social, a polarização e a desigualdade social. Transformações apenas começaram no Brasil e cidades como São Paulo tendem a ampliar sua área de influência, exportando linhas de produção da indústria, mas concentrando as sedes administrativas das empresas $^{3}$. O que vem provocar uma interiorização do crescimento: a formação de novas aglomerações urbanas e a volta do crescimento da população rural, um fenômeno idêntico ao que vem ocorrendo em alguns países da Europa.

Surge mais uma questão para a Sociedade em Rede: e no futuro, será possível fazer a distinção tradicional entre população rural e urbana? Acredita-se, que o aumento da população rural pode ser reação de sobrevivência mais que resultado da difusão das telecomunicações. Mas em grande parte do que se conta como crescimento rural é a difusão em espaços que, parecendo rurais, estão conectados a redes metropolitanas. 
IV. Impacto da Globalização no Desenvolvimento Local

Para os próximos anos, talvez para o próximo século, eis o nosso maior desafio: reequilibrar a relação entre tecnologia e sociedade. Vivemos numa era de super desenvolvimento tecnológico e subdesenvolvimento social e institucional. Se não mudamos, como pessoas e como sociedade, nosso extraordinário potencial tecnológico, fonte possível de criatividade sem precedentes, pode se converter em fonte de autodestruição. 


\section{Limites do Estado ${ }^{1}$}

As tendências evolutivas que hoje atraem a atenção sob a rubrica "globalização" modificam uma constelação histórica que se distinguiu pelo fato de o Estado, sociedade e a economia estenderem-se, de certa maneira, de forma coextensiva dentro das mesmas fronteiras nacionais. O sistema econômico internacional, no qual os Estados traçam as fronteiras entre a economia interna e as relações de comércio exterior, transforma-se, na esteira da globalização dos mercados, numa economia transnacional.

São relevantes, em primeiro lugar, a aceleração dos movimentos universais de capital e a avaliação imperativa das posições nacionais por meio dos mercados financeiros ligados globalmente em rede. Esses fatos explicam por que os atores estatais, hoje, não constituem mais os nós que emprestaram à rede global de relações de troca a estrutura de relações interestatais ou internacionais. Hoje, são antes os Estados que se acham incorporados aos mercados e não a economia política às fronteiras estatais.

O ímpeto de romper fronteiras não caracteriza, sem dúvida, apenas a economia. Ao abordar um tema de amplo espectro como, por exemplo, “Transformações Globais" deve-se considerar que ela contém, ao lado de questões sobre o comércio mundial, mercados financeiros e corporações multinacionais (com cadeias produtivas de alcance global), política interna mundial, correntes migratórias, questões novas como mídias e redes de comunicação, além das formas híbridas de culturas.

Ocorre um "rompimento de fronteiras" da economia, da sociedade e da cultura, num processo de ampla progressão, afetando as condições de existência do sistema estatal europeu, que desde o século XVII foi erigido sobre bases territoriais e que, como antes, eleva à cena política os atores coletivos de maior relevância. Esta constelação pós-nacional põe de lado essa engrenagem construtiva entre, de um lado, a política e o sistema jurídico, e, de outro, a circulação econômica e as tradições nacionais dentro das fronteiras do Estado territorial.

As tendências descritas sob a rubrica "globalização" não ameaçam somente no campo interno uma composição comparativamente homogênea da 
população - ou seja, o fundamento pré-político da integração dos cidadãos - por intermédio da imigração e da segmentação cultural. Ainda mais contundente é a circunstância de um Estado, cada vez mais enredado na interdependência entre economia e sociedade mundiais, perder autonomia e capacidade de ação, bem como substância democrática.

A tomada de partido pela globalização ampara-se numa ortodoxia neo liberal que, nas últimas décadas, conduziu a mudança para políticas econômicas orientadas pela oferta. Onde se recomenda a subordinação incondicional do Estado ao imperativo de uma integração social planetária por meio dos mercados e aconselhando-se um entrepreneurial state, que se afasta do projeto de acomodação da força de trabalho e, sobretudo, da proteção estatal de recursos da esfera mundana.

O Estado, agrilhoado ao sistema econômico transnacional, abandona seus cidadãos à afiançada liberdade negativa de uma competição mundial e se limita a pôr à disposição infra-estruturas que tornem atraente sua própria posição sob a perspectiva da rentabilidade que fomentem atividades empresariais.

Segundo a variante defensiva, não há mais como anular a subordinação da política ao imperativo de uma sociedade mundial integrada pelo mercado. O Estado nacional não deve cumprir somente um papel reativo em vista das condições de utilização do capital de investimento, mas também um papel ativo em todas as tentativas de qualificar os cidadãos da sociedade e capacitá-los à competição. A nova política social não é menos universalista do que a antiga. Mas ela não deve, em primeiro lugar, servir de resguardo contra os riscos padrões do trabalho, e sim dotar as pessoas com qualidades empreendedoras típicas de "realizadores", que saibam cuidar de si próprios.

A política, agora, só será capaz de "ter precedência" sobre os mercados globalizados quando lograr produzir na política interna, a longo prazo, uma sólida infra-estrutura que não seja desvinculada dos processos democráticos de legitimação. Considere-se que remediar a limitação do poder estatal na era da globalização é impossível, a globalização exige sobretudo o revigoramento das forças libertárias da sociedade civil, ou seja, a iniciativa privada e a responsabilidade dos cidadãos. 
IV. Impacto da Globalização no Desenvolvimento Local

A questão passaria a ser um problema da dinâmica global aliada a um universo de vida local. A opção primordial é ir além dos Estados nacionais, perseguir um plano supranacional e global, onde o poder destrutivo ecológico, bem como social e cultural, do capitalismo planetário estaria novamente posto sob controle. 


\section{Espaço e Tempo}

Ao abordar a questão da globalização, Milton Santos, professor de geografia humana na Universidade de São Paulo, lembra que "somente a história nos instrui sobre o significado das coisas. Mas é preciso reconstrui-la sempre reconstrui-la, para incorporar novas realidades e novas idéias ou, em outras palavras, para levarmos em conta o tempo que passa e tudo muda".

Segue, ainda, considerando que "A historia do homem sobre a Terra é a história de uma rotura progressiva entre o homem e o entorno. Este processo se acelera quando, praticamente ao mesmo tempo, o homem se descobre como indivíduo e inicia a mecanização do Planeta, armando-se de novos instrumentos para tentar dominá-lo. A natureza artificializada marca uma grande mudança na história humana da natureza. Hoje, com a tecnociência, alcançamos o estágio supremo dessa evolução".

Onde nos leva a civilização em seus inovadores rumos? "Esta evolução culmina, na fase atual, onde a economia se tornou mundializada, e todas sociedades terminaram por adotar, de forma mais ou menos total, mais ou menos explícita, um modelo técnico único que se sobrepõe à multiplicidade de recursos naturais e humanos".

"Assim é nessas condições que a mundialização do planeta unifica a natureza. Suas diversas frações são postas ao alcance dos mais diversos capitais, que as individualizam, hierarquizando segundo lógicas com escalas diversas. À uma escala mundial corresponde uma lógica mundial que nesse nível guia os investimentos, a circulação das riquezas, a distribuição das mercadorias. Entretanto cada lugar é ponto de encontro de lógicas que trabalham em diferentes escalas, reveladoras de níveis diversos, e às vezes contrastantes, na busca da eficácia e do lucro, no uso das tecnologias do capital e do trabalho. Assim se redefinem os lugares: como ponto de encontro longínquos e próximos, mundiais e locais".

Perde-se as referências, pois dentro do atual sistema da natureza, o homem se afasta em definitivo da possibilidade de relações totalizantes com o seu próprio quinhão do território. Há razões suficientes para se indagar qual a fração 
da natureza que cabe a cada indivíduo ou a cada grupo, se o exercício da vida exige de todos uma referência constante a um grande número de lugares?

"Ali mesmo, onde moro, freqüentemente não sei onde estou. Minha consciência depende de um fluxo multiforme de informações que me ultrapassam ou não me atingem, de modo que me escapam as possibilidades hoje tão numerosas e concretas de uso ou de ação. O que parece estar ao alcance de minhas mãos é concreto, mas não para mim. O que me cabe são apenas partes desconexas do todo, fatias opulentas ou migalhas. Como me identifico, assim, com o meu entorno?", indaga-se Santos.

Talvez possa se considerar, como estabeleceu Ianni (1994):

"As noções de espaço e tempo, fundamentais para todas as ciências sociais, estão sendo revolucionadas pelos desenvolvimentos científicos e tecnológicos incorporados e dinamizados pelos movimentos da sociedade global. As realidades e os imaginários lançam-se em outros horizontes, mais amplos que a província e a nação, a ilha e o arquipélago, a região e o continente, o mar e o oceano. As redes de articulações e as alianças estratégicas de empresas, corporações, conglomerados, fundações, centros e institutos de pesquisas, universidades, igrejas, partidos, sindicatos, governos, meios de comunicação impressa e eletrônica, tudo isso se constitui e desenvolve tecidos que agilizam relações, processos e estruturas, espaços e tempos, geografias e histórias. O local e o global estão distantes e próximos, diversos e mesmos. As identidades embaralham-se e multiplicam-se. As articulações e as velocidades desterritorializam-se e re-territorializam-se em outros espaços, com outros significados. O mundo se torna mais complexo e mais simples, micro e macro, épico e dramático".

\section{Complementa Santos:}

"Há hoje, um relógio mundial, fruto do progresso técnico, mas o tempo-mundo é abstrato, exceto como relação. Temos, sem dúvida, um tempo universal, tempo despótico, instrumento de medida hegemônico que comanda o tempo dos outros. Esse tempo despótico, instrumento de medida hegemônico, que comanda o tempo dos outros (...) é responsável por temporalidades hierárquicas, conflitantes, mas convergentes. Nesse sentido todos os tempos são globais, mas 
não há um tempo mundial. O espaço se globaliza, mas não é mundial como um todo, senão como metáfora. Todos os lugares são mundiais, mas não há um espaço mundial. Quem se globaliza mesmo, são as pessoas e os lugares”.

Dessa maneira há de se imaginar o indivíduo como um ser no mundo, mas pode-se pensar que há um homem total em um mundo global? Não há dúvida, entendido como sistema, o ser humano econômico é cada vez menos local e cada vez mais universal suas atividades produtivas. 


\section{Desenvolvimento sem Trabalho}

Há algumas considerações pessimistas quanto ao futuro do emprego, como a de Gorender (1997), considerando que: “o desemprego estrutural é uma epidemia econômica do final do século, vinculado à globalização e decorrente dela e tão inevitável quanto ela, assemelhando-se a AIDS, que contamina a todos sem distinção de qualquer espécie. Ricos e pobres. Desenvolvidos e subdesenvolvidos. A questão inscreve-se na ordem do dia de todos os países”.

Em mais um abordagem catastrófica, Forrester (1997) concluiu que “um desempregado, hoje, não é mais objeto de uma marginalização provisória, ocasional, que atinge apenas alguns setores; agora, ele está às voltas com uma implosão geral, com um fenômeno comparável a tempestades, ciclones e tornados", mais além o autor diz "imaginar os acontecimentos possíveis sob um regime totalitário, que não teria qualquer dificuldade para se mundializar, e que disporia de meios de eliminação de uma eficácia, uma amplitude e uma rapidez jamais imaginadas: genocídio”.

Também existem visões religiosas. Masi (1999), por exemplo, diz ser o trabalho uma maldição bíblica. Acredita ele que o trabalho, afinal, "vem há séculos se desenvolvendo em lugares indecentemente feios, onde uma pessoas deve passar muito tempo, gastando muita energia, com rituais inúteis. É conveniente lembrar que já se vai mais de um século, em 1857, quando Karl Marx escreveu: É chegado o tempo em que os homens não mais farão o que as máquinas podem fazer, concluindo que o capitalismo, tendendo de forma inexorável para a abolição do trabalho, teria desta forma provocado sua própria morte".

Investigar a decadência da sociedade capitalista talvez seja o foco ideal para contornar a situação e evitar, como prevê Kurz (1999), em um mundo de economia de mercado e democracia, onde nem a economia de mercado nem a democracia são suficientes, o surgimento dos escravos globais. Pois percebe-se que a lógica do imperialismo continua a existir, com suas táticas de exclusão e criação de uma cultura unipolar, onde os EUA prevalece como a última grande potência bélica. Embora esteja ficando cada vez mais claro que em um espaço 
econômico globalizado de cunho empresarial toda política expansionista tradicional perca o sentido.

Mas será o desemprego um sintoma de final de século? Parece tudo ser novo. O que não é verdade. $\mathrm{O}$ fenômeno vem ocorrendo desde o final dos anos 70 e a sensação é que apenas agora a revolução da microeletrônica substitui em proporções crescentes, na ampla gama de atividades rotineiras da economia industrial, a força de trabalho humana pela tecnologia informática e robotizada. $\mathrm{E}$ mesmo assim, a sociedade ainda não está preparada para enfrentar este desafio: o desenvolvimento sem trabalho.

Há de se pensar na pergunta que um dia fez Dahrendorf": "A sociedade do desenvolvimento foi também uma sociedade do trabalho. A vida dos homens era construída em torno do trabalho. A educação era orientada como preparação para o mundo do trabalho, o tempo livre como descanso para o novo trabalho. Além disso o trabalhador não era apenas considerado necessário para ganhar com o que viver, mas também como valor em si. Havia um orgulho no próprio trabalho e nas realizações no trabalho. A preguiça era severamente estigmatizada. Pode-se até mesmo dizer que a figura do homem trabalhador representou o ideal desta sociedade. Resta-nos perguntar: o que irá acontecer quando à sociedade do trabalho, o próprio trabalho irá faltar?”. 


\section{Conclusão - A Cidade Cognitiva: Proposição para o Desenvolvimento Local na Era do Conhecimento}

1. O Problema: Desenvolvimento Local na Era do Conhecimento, 305

2. A Proposição: A Cidade Cognitiva, 325

2.1 Fundamentação, 325

2.2 Proposição, 326 


\section{O Problema: Desenvolvimento Local na Era do}

\section{Conhecimento}

Os conglomerados industriais ao reformularem suas políticas de investimento para novos modos operacionais, onde prevalece a flexibilidade, tanto no aspecto do modo produtivo quanto na logística, abrem novas perspectivas em regiões periféricas ao processo de desenvolvimento industrial.

A reformulação destas políticas empresariais oferece às localidades um status estratégico nas economias das nações, graças à reformulação do modo produtivo industrial e relocação das infra-estruturas produtivas determinadas pela descentralização das plantas industriais flexíveis.

Vê-se o lugar como configuração territorial e, agora, como organização com regimes de regulação. A região não é mais o fruto de uma solidariedade orgânica, mas de uma solidariedade regulada e organizacional.

Organizado de dentro para fora das localidades, o desenvolvimento endógeno confere mobilização para otimizar os recursos de capital, de trabalho e institucional tanto quanto de infra-estruturas físicas e provoca o rompimento com o estruturalismo global e teorias espaciais onde etapas de desenvolvimento se sucederiam em estágios classificados como pré-industrial, industrial e pósindustrial.

A hierarquia dos lugares centrais, do pressuposto do espaço homogêneo, se quebra, pois regiões não serem homogêneas é condição para o sucesso de uma economia flexível, dependente das dinâmicas regionais.

Atributos "invísiveis" da comunidade são determinantes na locação dos empreendimentos, por exemplo, de alta tecnologia para os quais a inovação é um fator de vitalidade e sobrevivência.

O território, com todas suas características intrínsecas, materiais e imateriais, servindo como espaço econômico das atividades produtivas, deixa de ser um mero suporte espacial e torna-se um agente ativo do desenvolvimento. 
Emergem novas formas de regulação do espaço econômico urbano onde predominam normas estabelecidas mais pela sociedade civil do que pelo mercado ou pelo Estado.

O retorno da dimensão política local no desenvolvimento econômico é constatado no fato de que redes produtivas funcionam sob governança e colaboração mais que sob leis de mercado.

A governança na política de desenvolvimento local define o modelo de desenvolvimento materializado pelo bloco sócio-econômico territorial que determina a rede industrial e mão-de-obra que a dinâmica regional irá demandar.

As condições locais culturais, econômicas e sociais estabelecem a capacidade de inovação da governança em absorver os novos paradigmas para o desenvolvimento econômico.

A governança nutre elementos que viabilizam a inovação, tornando-a possível, como: infra-estrutura intelectual; força de trabalho qualificada; qualidade de vida; ambiente de negócios; capital de risco; mercado receptivo para novos produtos e processos; compromisso com a modernização industrial; cultura para a industrialização com flexibilidade e cooperação; e sistema social onde flui a inovação fundamentada na diversidade.

Diversificados pequenos núcleos industriais se encarregam de produtos cada vez mais customizados para mercados segmentados, permitindo que empresas maiores desconcentrem suas produções em unidades produtivas menores.

As grandes empresas ao atuarem com apoio e em forma de rede, não necessariamente localizada no mesmo país ou região, integram-se a um tecido internacional baseado em pequenas e médias empresas em diferentes regiões do planeta, fortalecendo as economias regionais, desde que capazes de reagir positivamente a esta reestruturação.

Para a estrutura produtiva local responder a estes estímulos, questões como integração e cooperação que possibilitam a articulação e complementaridade para integrar a cadeia produtiva de um produto industrial serial nas localidades, precisam ser entendidas pelas comunidades que devem 
intervir neste processo de transformação de forma que suas bases produtivas locais correspondam às necessidades dos ciclos de produção.

Crenças políticas sem compromisso social, como o neo liberalismo, ao buscarem a produção industrial competitiva de forma predadora, desarticulam a cooperação na base industrial existente nas regiões e extraem o elemento colaborativo, fator fundamental de uma real vantagem competitiva regional.

Sabe-se que o crescimento econômico, principal foco da política neo liberal, não garante processos de desenvolvimento político, ambiental, cultural, tecnológico e todos outros que envolvem a dimensão evolucionista humana, pois inter-relações progressivas destes processos limitam a capacidade motriz única do desenvolvimento econômico na complexa sociedade contemporânea.

A absorção consciente desta complexidade em uma estratégia competitiva e colaborativa, ao mesmo tempo que oferece às localidades condições de se estruturarem em suas bases produtivas, qualifica lideranças regionais a uma maior capacidade de análise, portanto a visão da economia deve ser ampliada com enfoques abrangentes.

As lideranças comunitárias precisam lutar para superar uma antiga visão paternalista, que predomina dentro e fora das administrações municipais sobre o gerenciamento estratégico da comunidade, impedindo que a capacidade institucional e organizacional do setor público comprometa o desenvolvimento econômico local.

A relutância do setor público em adotar políticas de desenvolvimento local por estas não darem visibilidade à comunidade de seus benefícios, sentidos a médio e longo prazo, deve ser combatida pela comunidade empreendedora.

Há em uma localidade empreendedora: economia aberta e fluente, sem obstáculos para novos negócios; estrutura social dinâmica, onde pessoas de fora são bem-vindas; predominância de negócios competitivos, sem grandes empregadores; finanças que contam com bancos competitivos e acesso a investimentos de risco; mão-de-obra especializada e profissional, com gosto para iniciativas inovadoras; governo com apoio a pequenos e novos negócios; inovação ofertada através de universidade e centro de pesquisa empresarial; mídia 
local que dá atenção para os empreendedores e para negócios inovadores; geração de empregos tendo como base o estímulo a novos e pequenos negócios; e uma atmosfera local repleta de amenidades como boa qualidade de vida, cultura, educação e lazer.

Nestas localidades, exige-se de seu governante também uma performance empreendedora na política de desenvolvimento econômico local, com características como: finanças transparentes; orçamento voltado para investimentos; escalões administrativos e executivos pensadores e visionários, com estilo profissional voltado para resultados; serviços públicos inovadores, competitivos e de alta qualidade; cultura de participação dos cidadãos, vistos como consumidores e acionistas do programa de desenvolvimento.

Isto faz com que se imponha uma ampla transformação de mentalidade que deve ocorrer não apenas nos políticos, mas também nos dirigentes privados, pois a comunidade empreendedora, ao mesmo tempo que exige um novo modelo de administração pública mais ativo no campo econômico, coloca a comunidade empresarial em uma nova dimensão produtiva, onde a eficácia de sua operação no território está ligada a cooperação efetiva com os agentes locais de desenvolvimento.

Ocorre uma minimização da origem militar do termo estratégico, pois este tipo de planejamento identifica de forma eficiente e sistemática as vantagens e desvantagens de uma área, e ao determinar oportunidades para seu desenvolvimento, fornece um senso de direção para programas locais, provendo um cenário para a avaliação e modificação do programa de desenvolvimento da localidade e sua região, e ainda permitindo a integração de atores independentes à função de planejar, a qual deixa de ser exclusividade do setor público.

Identifica-se o surgimento de um ator fundamental nas comunidades para conduzir o exercício deste processo à capacitação: o empreendedor cívico.

O inovador papel do empreendedor cívico exige o desejo de construir conexão e integração eficazes entre sua região e a economia global.

A atuação deste agente do desenvolvimento local irá moldar a localidade para relações internacionalizadas, em que uma cultura de 
compartilhamento de visão, trabalho, decisões e ações seja a força motriz do desenvolvimento econômico da comunidade, fundamentada na competitividade colaborativa.

Nesta perspectiva, a condução de processos de desenvolvimento regional sob o amparo de planejamento apoiado pela lógica de uma coordenação externa central cede lugar a planos de gestão das iniciativas locais, possível através do conceito de agência de desenvolvimento local.

A agência tem sua gestão voltada para consecução de projetos sob uma visão territorial que norteia a difusão do crescimento econômico e a geração de empregos a partir do gerenciamento de potenciais endógenos regionais.

Altera-se o padrão centralizado de formular e operar políticas, tradicionalmente marcado pela verticalidade na relação Estado-Sociedade, pela generalidade espacial e segmentação setorial, ocorrendo um padrão descentralizado, caracterizado pela horizontalidade na relação dos agentes sociais e pela seletividade espacial, integração e territorialidade de uma política regional.

Reconhece-se que recursos gerenciais e interpretativos mais adequados ao desenvolvimento econômico se encontram no setor privado, porém empresas dispõe de cobertura territorial limitada, pouco tempo e poucos recursos para compreender e enfrentar questões de responsabilidade social.

Agências de desenvolvimento representam uma forma de apoio eficaz, pois permitem incorporar características essenciais do mundo de negócios ao objetivo coletivo de desenvolvimento de uma comunidade como um todo, econômico, social e cultural.

A agência constituída com a participação do setor público em parceria com o setor privado, é a estrutura mais flexível que uma comunidade pode contar para adquirir competitividade regional, viável através da colaboração entre os agentes econômicos e sociais de sua região de atuação e na cooperação interinstitucional.

A posição de vigilante sobre a economia, sobre a vida social e cultural de uma região da agência de desenvolvimento necessita de uma compreensão profunda dos problemas e potenciais da área geográfica de sua atuação. 
Exige-se da agência uma forte habilidade de trabalhar com as estruturas econômicas, políticas, culturais e sociais já existentes na região, obedecendo a um padrão de intervenção concreto e operacional, útil e importante econômica e socialmente, pelo estímulo à criação de novos empregos, de novas oportunidades e novas soluções, o que releva seu foco para o desenvolvimento tecnológico e a inovação.

Tarefas contínuas complexas são exigidas para a implantação destas estruturas de cooperação e estratégia, onde o desenvolvimento institucional é a base do seu funcionamento descentralizado.

Insuficiente desenvolvimento institucional das comunidades e descontinuidade da política estadual foram os principais problemas para a implantação do plano de desenvolvimento econômico descentralizado "Estratégia Competitiva do Estado" elaborado pelo IPT para a SCTDE/SP.

Com táticas baseadas em seminários regionais em algumas regiões administrativas do estado de São Paulo, visando despertar interesse nas lideranças políticas e empresariais dos municípios, este plano do governo estadual paulista não obteve uma adesão significativa das comunidades do interior para criação de suas agências de desenvolvimento local: as ADLs.

A agência de Ourinhos, uma das poucas ADLs implementadas sob estímulo da SCTDE/SP, por exemplo, não obteve credibilidade perante a comunidade pela resistência de segmentos políticos e empresariais locais que a viam como uma concorrente na disputa pelo espaço político e não como uma entidade comunitária que estaria lutando para ir adiante com seus projetos e que buscava recursos, financeiros e humanos, e apoio político para o crescimento da economia da região.

A atuação da $\mathrm{ADEO}$ em Ourinhos, porém, não deve ser vista como um fracasso, pois ao levar à discussão da comunidade problemas locais para o desenvolvimento econômico obrigou suas lideranças a refletir sobre o futuro da cidade e formular ações para explorar suas potencialidades para o crescimento.

A agência de Ourinhos pode ser considerada uma iniciativa inovadora no desenvolvimento comunitário ao orientar as políticas locais no cenário 
macroeconômico nacional e internacional, dando sentido estratégico às decisões de investimento tanto do setor público quanto do privado e, ao criar uma atmosfera progressista de cidade empreendedora, a agência estimulou o surgimento de outras ferramentas de participação comunitária, como o Orçamento Participativo e o Banco do Povo, contribuindo para o desenvolvimento cívico de seus cidadãos.

As grandes falhas da ADEO foram a avaliação de sua própria capacidade de articulação interinstitucional e a fraca atuação de seus dirigentes para mobilização dos segmentos produtivos e participação do meio acadêmico, o que levou a um esvaziamento da organização como entidade capaz de viabilizar recursos em nível externo à municipalidade e agrupar esforços comuns pró desenvolvimento local.

Conectando as duas iniciativas, a da cidade de Ourinhos e a do estado de São Paulo, verifica-se a necessidade de uma efetiva política central de descentralização para estimular o fluxo de esforços locais a superar o aparente paradoxo que ocorre em função da interferência de governos centrais em ações eminentemente regionais e endógenas, caracterizadas como do âmbito exclusivo da política local e sujeitas a pressões particulares da política local.

Este paradoxo deve ser superado com planejamento descentralizado respeitando a relevância do contexto social, econômico, político e cultural regional como observado no plano colocado em prática pelo governo federal da Itália.

Concentrando-se na continuidade e mudanças de políticas regionais italianas, percebeu-se que as diferenças no desempenho dos governos locais têm ligações profundas com a história de cada região a qual explica aspectos específicos de sua vida cívica e, portanto do desenvolvimento econômico regional.

O desempenho das instituições regionais, criadas pelo governo central italiano, foram dependentes dos meios econômicos, sociais, culturais e políticos, que por sua vez dependeram da dinâmica e da ecologia do desenvolvimento institucional. 
Na Itália a industrialização tem sido um processo determinado, na sua organização espacial e econômica, pela sociedade regional que o suscitou, tratando-se de uma construção social do mercado, de um desenvolvimento apoiado e modelado pelas características culturais e históricas regionais.

A reconhecida eficiência do modo produtivo da região da EmíliaRomagna, por exemplo, é alavancada por um sistema complexo de relações entre empresas e centros de serviços horizontais que agem como interface setorial entre as empresas, e pela cadeia produtiva, em que fornecedores externos são a força maior de um sistema de manufatura que cria a possibilidade de progresso para empresas menores, geralmente familiares, que trabalham em redes de produção.

Este tipo de estruturação é observado na formação de aglomerações industriais nas regiões sul e sudoeste do Brasil onde, embora prevaleçam relações familiares de imigrantes europeus, lideranças regionais e locais, empresariais e políticas têm procurado criar alguma autonomia na política industrial local.

Notou-se em levantamentos que nas aglomerações industriais identificadas pelo IPEA os modelos são semelhantes entre si, procurando envolver instituições tradicionais de qualificação de mão-de-obra, como o SENAI, e de gerenciamento, como o SEBRAE, além de fomento, como o BNDES e de ensino, geralmente escolas técnicas e universidades da região, mas guardam particularidades regionais.

Há iniciativas com resultados positivos, entre outras, em: Blumenau, onde uma rede de empresas têxteis viabilizou a Fundação Blumenau Fashion, arranjo institucional voltado à capacitação tecnológica do setor de confecção; Criciúma, onde produtores locais criaram o Centro de Tecnologia em Cerâmica; Vitória, que estimula interação da universidade local com empresas de metalurgia através do Centro Capixaba de Desenvolvimento Metal-mecânico; Santa Rita do Sapucaí, onde Luiza Rennó Moreira através de articulações com a Escola Federal de Engenharia de Itajubá e com grandes empresas do setor de telecomunicações, obteve a geração de spin-offs das instituições de ensino locais e, consequentemente, a formação de pequenas e médias empresas na área de eletrônica e telecomunicações; São Carlos, que através da Fundação ParqTec 
criou o Centro Incubador de Empresas Tecnológicas, com empresas nas áreas de instrumentação, mecânica de precisão, microeletrônica, robótica, automação e novos materiais e Votuporanga, que com sua AIRVO, estabeleceu um pólo moveleiro na região conseguindo a inserção das empresas locais no mercado internacional.

Existem iniciativas com resultados negativos também, como o de Colatina, que, embora tenha investido na criação de seu Centro Tecnológico das Indústrias de Confecção do Espírito Santo, pouco o utiliza, podendo-se atribuir esta dificuldade à deficitária estrutura gerencial do setor, basicamente constituído de empresas pequenas e familiares de vestuário.

No Brasil, nas aglomerações consideradas pólos tecnológicos, como Campinas, São Carlos, São José dos Campos, Rio de Janeiro e Florianópolis, o necessário processo de inovação sofre dificuldades por não atingir uma sinergia crescente, o chamado spin-off, onde pesquisadores acadêmicos se sentiriam estimulados a participar de projetos concretos em grandes empresas, possivelmente pelo não comprometimento destas, geralmente multinacionais cujas matrizes situam-se em outros países.

Verificou-se que a estruturação de um pólo tecnológico internacional, como o modelo de Sophia Antipolis, uma bem-sucedida estratégia de desenvolvimento de uma região tradicionalmente de vocação turística, aparentemente sem fatores locacionais atraentes para a logística de empreendimentos de alta tecnologia, os principais fatores de sucesso no processo de inovação foram: aeroporto internacional com vários destinos; infra-estrutura de telecomunicações avançada; cooperação entre as empresas; maior produtividade dos profissionais; disponibilidade de profissionais de alta qualificação; presença de centros universitários de alto nível; vida social e cultural com diversidade e qualidade; grandes espaços verdes vizinhos às empresas; boa oferta de profissionais de saúde e de colégios internacionais com ensino bilingüe.

Problemas também existem em Sophia Antipolis, principalmente devido a seu rápido crescimento alguns serviços estão deficientes: os colégios 
internacionais não oferecem novas vagas, as administrações públicas não têm representação em Sophia e o custo de vida se tornou muito alto.

Outra dificuldade crescente no desenvolvimento interno do Tecnopoles francês deriva da inexistência de spin-off dos centros de ensino e pesquisa com as grandes empresas, o que o faz muito depende da chegada de novas empresas para continuar a crescer e absorver a formação qualificada de mão-de-obra na região.

Esta ausência de sinergia é um problema gerado, principalmente, pela atração de empresas cujos centros de decisão estão nos EUA e que não têm liberdade para fomentar oportunidades de colaboração com empresas locais, o que faz Sophia Antipolis ter alguma semelhança com os pólos tecnológicos brasileiros.

Portanto, a capacitação para a inovação tecnológica em um pólo não é fruto apenas da integração entre empresas e a comunidade acadêmica, mas depende também de uma atmosfera regional de cooperação entre empresas que favoreça a sinergia produtiva, uma vantagem competitiva identificável de forma exemplar na região da Emilia-Romagna, como se viu anteriormente.

Pode-se concluir que este fenômeno não se caracteriza apenas como resultado de uma articulação entre potenciais parceiros de uma comunidade interessada em uma dinamização de sua base produtiva através da incorporação de empreendimentos de base tecnológica, há uma complexidade maior.

Isoladamente, o pólo não consegue desencadear um processo de desenvolvimento econômico regional, pois um projeto que tenha por objetivo o desenvolvimento local fundamentado em empreendimentos de base tecnológica deve considerar o território regional como o espaço produtivo pleno de inovação.

Este paradigma traz em seu bojo a esperança de um real desenvolvimento sustentável, denominando-se tais regiões como Tecnópolis, onde ocorre o desenvolvimento do conhecimento.

Arquitetura com equilíbrio, edifícios envolvidos por um ar leve e agradável em meio a impecáveis paisagens, onde pessoas trabalham felizes em ambientes puros e saudáveis, com o urbanismo e a infra-estrutura dando suporte a 
uma atmosfera propícia à troca de conhecimento e estimulando a criatividade. Esta imagem utópica da "Nova Economia", está representada em um ícone que começa a ser impresso em nossas mentes: as Tecnópolises.

Globalização, tecnologia da informação, mercados emergentes e reorganização da administração governamental, gerando nova informação e novo conhecimento, materiais básicos para a inovação, estarão em um mesmo lugar: as Tecnópolises, graças às parcerias que formam a matriz de colaborações, no nível local e regional, alinhadas para trabalhar com as desafiadoras forças da "Nova Economia".

Mas notou-se também que interações sociais e econômicas complexas provocadas pelo impacto da economia informacional dentro de espaços urbanos regionais, coexistindo com intensos fluxos de informação e comunicação, podem provocar desequilíbrio nas comunidades.

É o caso de Bangalore, na Índia, que vem apresentando uma crescente tensão urbana provocada por deficiências crônicas, como pobreza crescente e desigualdade de renda, ao lado de um mercado imobiliário caótico, advindas da maciça imigração de regiões vizinhas com desequilíbrio sociais.

Este problema da imigração também foi detectado no Japão, com inchaço de Tóquio e sua área metropolitana, onde se concentram indústrias de alta tecnologia, o que determinou um plano de abrangência nacional que visava dar condições de desenvolvimento tecnológico a várias regiões, algumas delas, aparentemente, sem vocação para isto, para reverter o fluxo de imigração.

O equilíbrio no desenvolvimento regional através de uma igualdade nas oportunidades oferecidas pela "Nova Economia" global é o grande objetivo do programa japonês das Tecnópolises, mas atingir plenamente esta meta depende de solução para sérios problemas, como: a integração das cidades periféricas às facilidades educacionais, de pesquisa e desenvolvimento, e utilização das infraestruturas para implantação de indústrias de alta tecnologia pelas empresas locais; a síndrome do braço operacional ${ }^{1}$; fraca integração entre as universidades e as indústrias, devido à forte regulamentação da atuação das universidades públicas e escassez de profissionais de alto nível para as pesquisas que preferem permanecer 
nas universidades de primeira linha que se localizam nas regiões metropolitanas e que oferecem melhores oportunidades de trabalho devido à proximidade com as matrizes das grandes indústrias.

A principal dificuldade é a criação de spin-off nas regiões fora do eixo Tóquio-Osaka, tendo como principal causa a rigidez formal dos pesquisadores japoneses, mas também causada, como em Sophia e nos pólos brasileiros, pela limitação de autonomia das filiais para desencadear o processo de inovação.

O resultado é que a estratégia japonesa de promover a construção, estruturação e operação de plantas de filiais de seus grandes conglomerados industriais não garantiu a capacidade de inovação tecnológica às regiões e não alavancou significativamente o desenvolvimento regional de forma ampla e nacionalmente, como era objetivo do programa, pois estas plantas não ofereceram estabilidade no desenvolvimento econômico e tecnológico regional.

Estas iniciativas do Japão, em estruturar adequadamente suas regiões periféricas no cenário tecnológico que se descortina, são pioneiras e, embora suscetíveis a erros, avançam no conceito de desenvolvimento regional baseado tecnologicamente, servindo como modelagem para a questão da política de descentralização industrial pela sua abrangência territorial e continuidade política, passando por vários governos sem alteração significativa, condição essencial para a credibilidade do projeto.

A combinação de iniciativas locais com nacionais para manter seu posicionamento tecnológico global faz do Japão o centro das atenções pela amplitude e ambiciosa perspectiva, mas uma grande dificuldade será vencer a extrema rigidez estrutural de sua economia fundamentada na aliança tradicional entre as empresas e o governo federal, o que não deixa de criar uma espécie de "monopólio" da inovação, desestimulando a difusão dos empreendimentos de base tecnológica para as regiões periféricas.

No processo criativo necessário para a indução da inovação tecnológica, a agilidade das estruturas produtivas tem papel fundamental, pois há uma imposição de flexibilidade permanente para se adaptar às novas e constantes transformações decorrentes da competitividade global. 
A busca por soluções inovadoras não envolve apenas o indivíduo, mas impõe a reflexão que envolve a estrutura da comunidade como um todo dentro de um amplo contexto coletivo, onde o território é campo de uma constante afirmação da população que com ele interage, participando de forma pró-ativa com seus recursos endógenos, buscando a flexibilidade e criatividade, com base no desenvolvimento histórico e cultural da sociedade local.

Há esta conexão no posicionamento estratégico de Londrina, onde se denota o resgate das iniciativas empreendedoras do início da colonização no Norte do Paraná em meados dos anos 40, com a percepção de políticos e empresários locais de que havia um ineficiente aproveitamento do potencial de desenvolvimento de Londrina, que acabaram por contratar uma consultoria internacional para requalificar a cidade através de uma industrialização conduzida pelo senso comum da comunidade.

Ao buscar a correção do rumo de sua história, Londrina faz um correto resgate do seu empreendedorismo, caracterizado pela criação comunitária das principais empresas de serviços públicos, as quais deram suporte ao crescimento das atividades econômicas desta região desde sua fundação, dirigindo esforços da coletividade à crença que prevalece no cenário global contemporâneo: tecnologia como base para o desenvolvimento regional.

Mas, se por um lado, Londrina acertou na direção, ainda não encontrou o caminho para concretizar os anseios da comunidade, como mostra a situação atual do seu PDI, cuja implementação acabou ficando no âmbito burocrático de uma autarquia municipal em vez de uma agência de desenvolvimento autônoma, como foi sugerido pelos consultores e comunidades para garantir a perenização do processo de interferência coletiva no desenvolvimento local.

Uma tentativa de reintegração do PDI à comunidade é realizada pela organização não-governamental ADETEC, pois o "mapa tecnológico" de Londrina, idealizado pela entidade com objetivo de identificar competências tecnológicas existentes na região que permita a união do meio acadêmico às cadeias produtivas regionais, partindo do diagnóstico industrial elaborado no PDI, 
pretende recriar um ambiente de cooperação entre as universidades e empresas da região, com isto poderá estar desfazendo o marasmo ocorrido no gerenciamento do desenvolvimento industrial, que não está ocorrendo de fato no âmbito da administração municipal local.

À idéia de remover gargalos tecnológicos e gerar inovações nos produtos e serviços produzidos no Norte do Paraná, projetando a cidade como sede de uma Tecnópolis de nível internacional, deve ser acrescida a discussão da estruturação na região de uma rede inter-institucional baseada tecnologicamente e inserida no meio produtivo regional.

A agência de desenvolvimento, indicada, como se viu no PDI de Londrina elaborado pela Andersen Consulting para gerir o programa de trabalho, atenderia a necessidade permanente de ajustes estratégicos no PDI, o que não é possível acontecer no âmbito municipal, burocrático por natureza, no qual se insere atualmente o plano; portanto para atingir a eficiência necessária o conceito desta instituição deve ser ampliado para a região que realmente interage com a região metropolitana de Londrina, refazendo-se a abrangência do plano.

A questão é saber se é viável nesta cidade do Norte do Paraná a formação concreta de uma Tecnópolis, que implica uma sociedade e economia intrinsecamente receptivas à inovação, pois para isto se exige: um sistema educacional que encoraje a criatividade e a busca do conhecimento científico e tecnológico; uma rede de laboratórios capaz de trabalhar em conjunto para desenvolver e adquirir conhecimento a partir de informação que venha de fora; uma estrutura para o desenvolvimento e controle de qualidade dos produtos, dentro das normas internacionais; recursos técnicos, como lojas de equipamentos e maquinários de precisão e computacionais; uma estrutura industrial que irá sustentar uma produtiva "ecologia industrial", na qual pequenos fornecedores potencialmente inovadores e orientados tecnologicamente servem grandes empresas que têm acesso aos recursos e ao mercado; instituições e programas que liguem pesquisadores e inventores a potenciais usuários do conhecimento que eles geram, tanto quanto aos investidores; um sistema legal para proteger inovações tecnológicas, tanto as locais quanto as importadas; um meio ambiente político econômico que encoraje a pesquisa, desenvolvimento e investimento em 
inovação; uma rede de energia elétrica confiável com boa freqüência e controle de amplitude; uma infra-estrutura de telecomunicações, comunicações e transporte adequada; além de uma excelente qualidade de vida urbana, o que implica em facilidades sofisticadas de lazer e culturais, inclusive um teatro de nível profissional, o que pode ser difícil de se acreditar, mas a cidade ainda não possui.

Diante da complexidade destas recomendações, vê-se que, para criar a atmosfera ideal de uma Tecnópolis em Londrina, impõem-se uma mobilização de recursos materiais e intelectuais que supera o âmbito local, repercutindo nas esferas de decisão do governo federal e estadual, estando também relacionadas a uma interação com as comunidades acadêmicas e empresariais nacionais e internacionais, onde estariam recursos financeiros capazes de assumir um projeto com esta envergadura.

Concluí-se que, mesmo contando com competência para implementar as ações locais necessárias, suficientemente comprovada com organizações que se mostram capazes de operacionalizá-las, como a ADETEC, e ainda fundamentando-as em bem elaborados planos estratégicos, que é o caso do PDI, se não houver um comprometimento do setor público em todas as suas instâncias, do local ao federal, muito pouco será alcançado para que de fato se possa considerar Londrina uma Tecnópolis no competitivo cenário internacional da complexa "Nova Economia".

Esta conclusão sobre a experiência da cidade do Paraná, serve para outras que devem enfrentar o incrível número de variáveis que se manifestam com a economia globalizada que cresce na mesma proporção em que se expande para além dos territórios nacionais e dos pólos tecnológicos regionais que criaram a base para seu desenvolvimento na escala global, o que provoca uma interdependência no processo de globalização das localidades.

Serão necessárias reflexões de como se deve compreender o sistema econômico como parte de um sistema mundial social com limitações de ordem estrutural, com grupos, membros e regras de convivência, buscando a coerência possível do resultado de forças conflitantes que mantém o sistema sócioeconômico equilibrado. 
Dessa maneira entendido, assemelha-se a um organismo, onde há um tempo que define o percurso da vida, ao qual se pode assistir mudar em alguns aspectos enquanto outros se mantém imutáveis em sua permanente evolução.

Penetra-se no âmago do urbanismo do fim de século, com questões urgentes como a destruição da estrutura familiar que ocasiona o surgimento de novos seres criados pela própria cidade: a cidade mãe, um lugar onde se drogam com a velocidade, com o álcool e agora com a Internet.

Conectada, a sociedade mundial pensa e trabalha ciberneticamente, tecendo uma rede física e emocional que extravasa territórios. Estar aqui ou mais adiante, lá onde se encontra alguém como nós, é uma questão de estar on-line.

A dinâmica da vida torna-se global, entretanto o universo cotidiano dos seres humanos está no locus. Portanto a grande questão é a cidade. Funde-se no local todos os desejos, todas as expectativas para nossas curtas existências enquanto seres temporais.

Tempo. Tirânico, impõe temporalidades conflitantes, convergentes. Nesse sentido todos os tempos são globais, mas não há um tempo mundial. "O espaço se globaliza, mas não é mundial como um todo, senão como metáfora. Todos os lugares são mundiais, mas não há um espaço mundial. Quem se globaliza mesmo, são as pessoas e os lugares”, diz Milton Santos (1998).

Como trabalhar com este persistente labirinto de nossa sociedade pluralística moderna e seus valores cada vez mais autônomos, onde se cria uma ampla incerteza não apenas econômica? Certo é que se vai cruzar por mares nunca dantes navegados com uma necessidade de enfoque econômico comparável à incerteza quântica do físico Max Planck.

Desenvolvimento é um processo, cujo planejamento jamais deve ser um produto entregue engessado e definitivo. Inserido neste contexto, a globalização com seus emergentes paradigmas, deve ser entendida como desafio contínuo decorrente da necessidade do homem de ir além de seus limites físicos e territoriais. Algo que vem ocorrendo desde o início da civilização, mas agora com velocidade antes nunca vista. 
Verifica-se que este processo se altera e sofre mutações operacionais constantes em função das inovações tecnológicas empurradas pela ansiedade do homem em abandonar o velho sítio em busca do rompimento com o passado, com o conquistado.

Estar em muitos lugares simultaneamente, colocando por terra o mais antigo dos temores: o tempo. Talvez seja esta a verdadeira conquista que a globalização, forjada pela civilização do século XX, deixa como legado para o próximo século.

Tempo. Velocidade. Suportes para a onda de uma competição no nível global baseada no crescimento da tecnologia de informação, viabilizando uma "Nova Economia" que emerge célere fazendo florescer comunidades que se conectam às transformações, competentes que são para compreender o processo complexo que esta conectividade exige.

A localidade propicia as ocasiões em um mundo que oferece as possibilidades e que "globaliza pessoas, seus lugares e suas regiões". Mas é na diversidade dos locus e na criatividade que suas culturas podem oferecer que está o berço do conhecimento e novas perspectivas para o futuro do desenvolvimento sustentável global.

É necessário, então, a elaboração de novos modelos para condução do desenvolvimento econômico de localidades no século XXI, compostos de atividades coletivas como:

1. definir visões estratégicas para compreender a relação localglobal;

2. criar processos de planejamento para que as comunidades possam conduzir este relacionamento;

3. adotar atitude de mercado em relação a produtos e clientes de suas regiões;

4. estabelecer qualidade em programas e serviços para competir com outras regiões; 
5. dispor de habilidade para transmitir e divulgar eficientemente suas vantagens competitivas;

6. diversificar sua base econômica e criar mecanismos para se adaptar flexivelmente às novas condições;

7. desenvolver e alimentar características empreendedoras;

8. estimular o setor privado para assumir responsabilidade social;

9. elaborar projeto próprio de transformação econômica, como resultado das diferenças culturais, políticas e processos de lideranças;

10. criar mecanismos organizacionais e executivos que sustentem a sua implantação e mantenha, uma vez iniciada, a força do entusiasmo inicial pelo projeto de desenvolvimento local.

A reflexão sobre estas ações deve estimular a criação de instrumentos para executá-las, pois as forças poderosas, externas e internas, que interagem nas localidades, elevando a importância das regiões ao mesmo nível que das nações no desafio competitivo global, impõe um urgente capacitação dos recursos coletivos e individuais da comunidade

A competitividade regional irá depender da capacidade de sua comunidade para exercitar complexas funções, como:

a. integração, buscando a lógica do território com suas necessidades e potencialidades e apoiando as articulações entre o setorial e o global, entre o econômico, o social e o cultural;

b. mediação, amparando diversos atores para a concepção e realização de um projeto; favorecendo condições para a tomada de decisão e garantindo o fluxo permanente de informação e a conexão entre os atores;

c. inovação, arquitetando as necessidades da população e traduzindoas em um projeto de desenvolvimento viável e aceitável por todos; 
V. Conclusão - A Cidade Cognitiva:

Proposição para o

Desenvolvimento Local

na Era do Conhecimento

d. mobilização, promovendo as iniciativas da comunidade e garantindo a participação nos projetos dos recursos institucionais e humanos.

Conclui-se, sinteticamente, que há necessidade do estabelecimento de processos de civilidade na comunidade para que esta esteja capacitada para enfrentar com chances de sucesso os complexos desafios da era do conhecimento.

A questão é como realizar tais projetos de desenvolvimento local cujo modelo foi criado e desenvolvido em nações e localidades em que a sociedade tem a prática cívica, onde as inúmeras tarefas coletivas dependem da participação e cooperação, como hábito que remonta, às vezes, há centenas de anos de sua história em um país sem esta tradição, como o Brasil. 


\section{A Proposição: A Cidade Cognitiva}

\subsection{Fundamentação}

A partir da percepção de que:

O meio técnico-científico-informacional, mostrando-se cada vez com maior complexidade, conduz e permeia todas as atividades humanas, em uma cadeia sucessiva de transformações sociais e econômicas que se materializam no espaço territorial das comunidades;

O conhecimento, sendo recurso deste meio, validaria a utilização e funcionamento do espaço local como locus da produtividade global, garantindo para as regiões o encontro entre as possibilidades latentes e as oportunidades criadas pela "Nova Economia", e permitiria uma reação aos efeitos perversos que a globalização poderia estar trazendo para o desenvolvimento local;

A economia local jamais deverá estar estanque para ser competitiva, pois muda seu cenário permanentemente e, hoje, tão rápido quanto os fluxos de informação que atravessam os continentes;

Conquistas da civilização tecnológica contemporânea estão criando barreiras na comunicação entre as sociedades, excluindo comunidades incapazes de apreender a complexidade das relações em mutação. Um ruído no desenvolvimento sustentável global.

O abismo do conhecimento é o desafio na estruturação de regiões e localidades;

E, considerando-se que:

Adquirir conhecimento, significa estimular criatividade e desembocar na inovação, fator de vitalidade e sobrevivência das organizações da "Nova Economia" e das comunidades dinâmicas do mundo globalizado.

Pode-se afirmar que:

Há urgência de uma mudança radical na mentalidade coletiva. Como a que determinou a importância da tecnologia na Revolução Industrial durante o 
processo de transformação da sociedade agrária na sociedade industrial, agora com a metamorfose desta na sociedade digital a relevância é a cognição.

“Aquilo que chamamos Revolução da Informação é, na realidade, uma revolução do conhecimento. A rotinização dos processos não foi possibilitada por máquinas. $\mathrm{O}$ computador, na verdade, é apenas o gatilho que a desencadeou. O software é a reorganização do trabalho tradicional, baseado em séculos de experiência, por meio da aplicação do conhecimento e, especialmente, da análise lógica e sistemática. A chave não é eletrônica, mas sim a ciência cognitiva"”.

Estabelecendo-se que:

Aprender para não morrer - é o novo paradigma determinado pela globalização nas localidades na era do conhecimento;

O desenvolvimento local não é nem será mais como era - a destruição criativa imposta pela "Nova Economia" mundializada exige uma postura inédita nas comunidades: uma permanente necessidade de aquisição e processamento de informação e conhecimento.

\subsection{Proposição}

A idéia fundamental é que na economia da informação o desafio da competitividade regional ou empresarial depende da inovação. E inovação exige criação de conhecimento.

Inovação, conhecimento e competitividade apenas são sustentáveis onde disponham de um adequado sistema nacional de inovação, fator estratégico na competitividade de regiões e de suas organizações, através de uma eficiente mobilização permanente nas empresas, no complexo educacional, nos órgãos e agências governamentais.

“A competitividade só é viável através de uma adequada política nacional para a inovação, exigindo a formulação de um plano que foge ao escopo da economia de mercado. Entretanto é possível atingir objetivos econômicos sem abandonar o cômodo arcabouço dos tradicionais planos nacionais de desenvolvimento? Talvez se possa começar com algo como buscar a 
competitividade baseada na transformação das mentalidades embutindo-a na simbiose das políticas econômicas para políticas culturais. Onde o objetivo seja a compreensão de que a competência de uma sociedade só é possível com a aquisição do conhecimento através do estímulo à criatividade. Quebra-se o monopólio dos economistas neste novo tipo de política econômica pois há necessidade de "equipes interdisciplinares onde convivam economistas, antropólogos, filósofos, sociólogos, administradores, empresários, burocratas e... artistas"

Agora, quando se está à frente com a necessidade concreta de estimular o desenvolvimento regional, pode-se acreditar que manter viva a diversidade local, biológica e cultural, oferece uma riqueza de possibilidades que pode elevar a importância da comunidade à altura da sociedade do conhecimento.

Onde o bem maior da inovação significa criatividade, a qual não se alcança apenas por meio de equipes multifuncionais, mas também por meio da diversidade cultural, destacando o papel do conhecimento no espaço regional como fator de vantagem competitiva de empreendimentos, pois cria a atmosfera adequada para a sinergia empresarial e o fortalecimento das atividades locais.

A aglomeração regional produtiva cria vantagem colaborativa empresarial. Pequenas, médias e grandes empresas podem colaborar nos mesmos projetos e mais tarde se envolverem em novos projetos formando um processo contínuo em rede. As firmas compartilham talentos e capital intelectual através de um área geográfica comum onde empreendimentos de todos os portes desenvolvem malhas de relações para se auto-ajudarem a obter velocidade, qualidade, flexibilidade e conhecimento que são fatores essenciais para a vantagem competitiva no nível global.

Vantagem competitiva adquirida através de vantagem colaborativa regional. A vantagem colaborativa que advém do fato de que conhecimento é o novo recurso material das empresas e incorporado por pessoas se torna capital intelectual que é a fonte da vantagem competitiva. 
$\mathrm{Na}$ "Nova Economia" conhecimento, habilidades e experiência incorporados em indivíduos têm maior valor do que capital e por esta razão acredita-se que ela possa ser considerada como uma economia pós-capitalista. ${ }^{3}$

E, se:

A integração tecnológica ultrapassando as fronteiras geográfica dos países, determina uma crescente descentralização de políticas nacionais de desenvolvimento;

A "Nova Economia" mundializada incorporando fatores de produtividade como flexibilidade e inovação, depende de políticas locais de desenvolvimento;

A queda da barreira espacial nas relações econômicas e sociais da humanidade revela aos seres humanos a riqueza de sua diversidade cultural e a

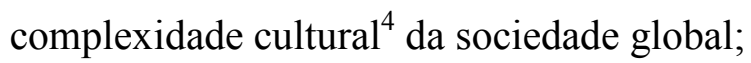

A técnica pela técnica não consegue garantir a participação dos indivíduos em uma sociedade tecnológica onde diferença não seja sinônimo de desigualdade;

A capacidade da humanidade em manipular os novos conhecimentos que brotam em permanente evolução, resultado de descobertas e pesquisas no nível global, incorporando-se no dia-a-dia das pessoas e organizações, tornar-seão realidade nas localidades;

A escala cultural humana para a aquisição de conhecimento, vital para viabilizar o processo de integração econômica mundial, não pode ser prescindida.

Deve-se considerar, então, que:

Há necessidade urgente de uma política operacionalizada com mecanismos de participação, decisão e sustentação nas comunidades que devem ser organizadas para ações locais com objetivo de estimular a conexão entre a economia regional e mundial através do fortalecimento do comportamento cívico do indivíduo enquanto ser intelectual e legitimando seu papel como cidadão do mundo.

Podendo-se concluir que: 
A importância do entendimento do entrelaçamento do microcosmo de uma localidade com a dimensão mundial é vital para um modelo de desenvolvimento; e

A sustentabilidade deste modelo é obtida através da capacidade da sociedade de conduzir sua própria experiência local.

E, afinal, chega-se à proposição da tese:

Que esta capacitação, até então função peculiar de desenvolvimentos institucionais históricos, tenha por princípio um processo cognitivo coletivo, viabilizando que o conhecimento, onde se encontram elementos que possibilitam a compreensão de relações complexas e abstratas, como são as da "Nova Economia", estabeleça as formas de organização e julgamento das idéias e conceitos necessários para a construção de um modelo original assimilável pela região de sua aplicação e, aperfeiçoando identidades culturais da população, contribua para o desenvolvimento sustentável global com criatividade e inovação.

Espera-se que com isto:

Constituam-se processos de civilidade nas comunidades brasileiras, capacitando-as para as inúmeras tarefas coletivas que os desafios da era do conhecimento, com complexidade, exigem;

Obtenha-se, através da percepção, compreensão e produção de conhecimento, aprimoramento de características culturais regionais que atenda a necessidade de condução da comunidade pelo incerto caminho da mundialização econômica por meio da instituição de uma mentalidade inovadora coletiva; e

As centenas de anos de história da prática cívica que foram necessárias para a modelagem do desenvolvimento de nações e localidades por suas sociedades colaborativas não sejam, assim, indispensáveis para desencadear em um país sem esta tradição, como o Brasil, processos que resultem em modelos de desenvolvimento econômico originais, pois estes seriam elaborados com criatividade e inovação pelas que poderiam então ser chamadas de cidades cognitivas. 


\section{Notas}

Parte I. Introdução, 332

Parte II. Desenvolvimento Econômico Local, 333

1. Introdução, 333

2. Aspectos do Desenvolvimento Econômico Local, 333

3. Agências de Desenvolvimento Econômico Local, 336

4. Experiências de Agências de Desenvolvimento, 336

Parte III. Desenvolvimento Industrial Descentralizado, 337

1. Introdução, 337

2. Experiência Italiana, 337

3. Industrialização Descentralizada no Brasil, 337

4. Os Pólos Tecnológicos, 338

5. As Tecnópolis, 339

6. Desenvolvimento Industrial em Londrina, 339

Parte IV. Impacto da Globalização no Desenvolvimento Local, 340

1. Introdução, 340

2. Sociedade de Risco, 340

3. Catástrofe Urbana, 341

4. Sociedade em Rede, 341

5. Limites do Estado, 341

6. Espaço e Tempo, 341

7. Desenvolvimento sem Trabalho, 341

Parte V. Conclusão - A Cidade Cognitiva: Proposição para o Desenvolvimento Local na Era do Conhecimento, 341

1. O Problema: Desenvolvimento Local na Era do Conhecimento, 341

2. A Proposição: A Cidade Cognitiva, 342 


\section{Parte I. Introdução}

${ }^{1}$ Texto bíblico. In Almeida, João Ferreira (tradutor), A Bíblia Sagrada, Sociedade Bíblica do Brasil, Brasília, 1992.

2 Joseph Schumpeter denominou "destruição criativa" o processo de mudança das regras do jogo no comércio ou de inovação que abalando os mercados, resultaria na mudança de preços, jogadores e regras em toda a economia, e,com isto, um rearranjo dramático determinaria um processo que aumenta vertiginosamente a produtividade segundo os novos padrões, mas pode quebrar organizações.

${ }^{3}$ Adaptado de http://www.wedband.com/prometheus.htm, janeiro, 1999.

${ }^{4}$ Os laços com a tradição sempre trouxeram problemas em processos produtivos e, especialmente nos mecânicos como o têxtil. Conta Bicalho (1987) que o tear de fitas, vindo do Oriente e aperfeiçoado no Ocidente, permitia tecer várias fitas ao mesmo tempo, com um só operário para realizar um amplo trabalho. Porém, em 1579, as autoridades de Dantzig, temerosas do desemprego em massa que a mesma poderia provocar entre as tecelãs da cidade, suprimiram o invento e estrangularam o inventor. Na Inglaterra, não chegaram a estrangular o inventor, William Lee, mas ele teve que procurar refúgio na França quando demonstrou que sua máquina de tricotar meias, desenvolvidas a partir da observação dos movimentos manuais de uma tricoteira, poderia executar o mesmo trabalho com a mesma qualidade e dez vezes mais rápida.

${ }^{5}$ Ortega y Gasset, José - Meditação da Técnica, Editora Ibero-Americano, 1963. Em Gama (1986).

6 "Todos os criadores da nova ciência se deram conta de sua consubstancialidade com a técnica. Tanto Bacon como Galileu, Gilbert quanto Descartes, Huygens quanto Hooke ou Newton” Ortega Y Gasset (1963). Em Gama (1986).

${ }^{7}$ Haudricourt, André - La technologie, Science Humaine, em La Pensée, $n^{0} 115$, junho, 1964. Em Gama (1986).

${ }^{8}$ Canêdo (1987).

${ }^{9}$ Historiador grego, viveu de 484 a 425 a.c..

${ }^{10}$ Canêdo (1987).

11 Justificativa ainda hoje lembrada por oponentes das transformações tecnológicas que se sucedem em todos campos das atividades humanas.

12 Marcuse (1999).

13 Santos (1994).

${ }^{14}$ Embora se observe que a base da economia não tenha mudado, pois o regime continua a ser capitalista, como considerou Caron (2000), há pelo menos uma característica que difere a economia atual da que até então existia: a constituição de uma rede informação pela Internet, que viabiliza a construção de uma interatividade se desenvolvendo em forma de teia de aranha, por iniciativa de seus usuários e que pela ausência de um centro constituinte democratiza o acesso ao mercado de economias periféricas, ocorrendo o estabelecimento de novas relações 
produtivas, com fatores como flexibilidade e conhecimento, estabelecendo um novo paradigma econômico que vem sendo chamado de "Nova Economia".

\section{Parte II. Desenvolvimento Econômico Local}

\section{Introdução}

${ }^{1}$ Colman \& Nixson (1981).

${ }^{2} \mathrm{Na}$ busca por um eficiente índice de desenvolvimento surgiu uma interessante proposta: o Índice de Desenvolvimento Humano (IDH) que foi projetado para corrigir alguns dos defeitos do uso da renda per capita como medida de desenvolvimento. Este índice é uma composição de longevidade (expectativa de vida), instrução (combinação entre alfabetização adulta e média de escolaridade) e padrão de vida (poder de compra, baseado no PIB real per capita ajustado para o custo de vida local) e vem sendo aplicado em programa da ONU como o PNDU.

3 Economic Development Today: A Report to the Profession - American Economic Development Council, 1984.

${ }^{4}$ Morin, Edgar - Socielogie, Fayard, 1994. Em Gama (1986).

5 Georgescu-Roegen, N. - The Entropy Law and the Economic Problem, reprodução de conferência pronunciada na Universidade de Alabama, 1970. Em Furtado (1994)

${ }^{6}$ Santos, Amador \& Hernadez (1995).

${ }^{7}$ Agrupamento de empresas que viabilizam ciclos produtivos completos em uma mesma região. Ver também nota 4 da parte III.

8 Anteriormente verificou-se uma locação de grande empresas em pequenos aglomerados urbanos, porém, especialmente no Brasil, as indústrias atuavam isoladamente, não sendo especificamente uma estratégia dos setores industriais.

\section{Aspectos do Desenvolvimento Econômico Local}

${ }^{1}$ Lipietz (1994).

${ }^{2}$ Parente, Silvana \& Zapata, Tânia - Parceria e Articulação Institucional para o Desenvolvimento Local Integrado e Sustentável em Projeto Banco do Nordeste/PNUD, Série Cadernos Técnicos N. ${ }^{\circ}$ 04, Recife,1998. Em http://www. truemet.com.br/bnbpndu.

${ }^{3}$ Bingham \& Miers (1993) levantaram cerca de 50 teorias e modelos conceituais relacionadas a abordagens do desenvolvimento econômico local e as classificaram em seis enfoques: Teorias Locacionais e Espaciais, Teorias Estratégicas, Teorias Capital-Trabalho, Teorias Sociais e Políticas, Processo e Organização, e Perspectivas Teóricas.

4 Wassmer (1994) aplicou estes indicadores para análise estatística do desenvolvimento econômico urbano por serem eles os resultados mais esperados em política de incentivo municipal onde já se parte para uma classificação em categorias de negócios industriais e não-industriais. 
5 Ao contrário da produção seriada, a flexibilidade produtiva exigida pelas chamadas "séries de um" permitem prever a necessidade crescente dos processos produtivos serem compreendidos em toda hierarquia dos recursos humanos envolvidos, o que releva a importância da troca de informação e da democratização do conhecimento como fator competitivo industrial.

${ }^{6}$ Sengenberger (1993).

${ }^{7}$ Haddad (sem data).

${ }^{8}$ Porter, M.E.A. - A Vantagem Competitiva das Nações, Campus, 1993. Em Haddad (sem data).

${ }^{9}$ Manzagol (1985).

${ }^{10}$ Premus obteve este levantamento em 1982, consultando altos executivos de empresas de alta tecnologia através da solicitação que os mesmos classificassem cada fator ou atributo como muito significante, significante, pouco significante ou não significante com respeito a escolha da localização de suas empresas. Nesta tabela o número das classificações muito significante e significante foram somadas para extrair o percentual do total dos formulários respondidos e assim se chegar a um suposto ranking dos atributos locacionais.

${ }^{11}$ Hall (1988).

12 Rede é um termo similar a aglomerado ou "cluster", aplicado por autores, como Alain Lipietz, para designar o modo de produção industrializado integrado distribuído em uma mesma região.

${ }^{13}$ Lipietz (1994).

${ }^{14}$ Em Globalização em Debate, Estudo Avançados, 11 (29), 1997.

${ }^{15}$ O objetivo da pesquisa da CED, realizada em 1987 nos 50 estados americanos, era obter um índice, consistindo de 7 categorias que sumarizavam cerca de 32 indicadores distintos que mostrariam a adaptação das administrações públicas ao novo cenário empresarial.

16 Osborne, D. - Laboratories of democracy, Harvard Business School Press, 1988 .

${ }^{17}$ Lodovici \& Bernareggi (1993).

${ }^{18}$ Bennington \& Geddes (1992).

${ }^{19}$ Idem, ibidem.

${ }^{20}$ Idem, ibidem.

${ }^{21}$ Barnekov \& Rich (1989).

${ }^{22}$ Warner, S. B. - The Private City: Philadelphia in Three Periods of Its Growth, University of Philadelphia Press, 1968. Em Barnekov \& Rich (1989).

${ }^{23}$ Blakely (1994).

${ }^{24}$ Competitividade regional neste estudo deve ser entendida também como uma competência, não exclusivamente como um fator de posicionamento para um competição entre regiões por investimentos externos. 
${ }^{25}$ Burnier considera estes fatores estruturais por serem dependentes da política econômica federal o que reduz a capacidade de intervenção dos agentes governamentais e privados locais nos projetos de desenvolvimento econômico.

${ }^{26}$ Destaca-se o programa Empowerment Zones Enterprise Communities, iniciado no governo Bill Clinton pelo governo dos EUA, que indica como ferramenta indispensável para integrar este programa adoção dos planejamento estratégico pela comunidade interessada em receber recursos federais.

${ }^{27}$ Green \& Fleischmann (1989).

${ }^{28}$ Doeringer \& Terkla (1990).

29 Fink, Ezra - The Role of Land and Facilities and Linkages Beteween Universities and High-Technology Industries - Em Goumain (1989).

${ }^{30}$ Sposito, Victor A. - Strategic Planning for Metropolis, Volume 1: A guide to strategic planning and management in the public sector, Department of Planning and Development Victoria, Melbourne, 1993.

${ }^{31}$ Idem, ibidem.

${ }^{32}$ Azevedo, Beatriz - A Dimensão Local do Desenvolvimento: Uma Aplicação ao Caso dos Países em Desenvolvimento, Indicadores Econômicos FEE, v.23, no.3, novembro de 1995.

33 "A sociedade do conhecimento é uma sociedade com três setores: o setor público, que é governo, o setor privado que é negócios e o setor social... é no e através do setor social que a sociedade moderna desenvolvida pode de novo criar responsabilidades e ganhar lideranças, pode novamente dar a indivíduos (e especialmente a pessoas com conhecimento) uma esfera na qual eles podem fazer a diferença na sociedade, uma esfera na qual eles podem re-criar a comunidade". Peter Drucker. Em Henton, Melville \& Walesh (1996)

\section{Agências de Desenvolvimento Econômico Local}

${ }^{1}$ Albuquerque, Francisco - La importancia de la produccion local y la pequeña empresa para el desarollo de America Latina, ILPES, Santiago do Chile, 1997. Em Macedo (1998).

\section{Experiências de Agências de Desenvolvimento}

${ }^{1}$ Soares, Vitor - Agências de Desenvolvimento Regional, cópia xerox, edição do autor, agosto, 1998.

${ }^{2}$ Manual do Projeto IQADE - Implementação e Qualificação de Agências de Desenvolvimento em Portugal, EURADA, sem data.

${ }^{3}$ O PDM é uma das propostas do IPT incluída no Plano Estratégia Competitiva do Estado. Além das ADL e do PDM, as outras propostas eram os Condomínios Industriais e a Agência de Informação do Estado de São Paulo.

${ }^{4}$ Estes municípios estavam presente na última reunião convocada para 12 de dezembro pela SCTDE/SP visando obter um balanço da situação da implantação das ADLs no estado de São Paulo.

${ }^{5}$ North (1996).

${ }^{6}$ Programa de Governo Mário Covas, setembro, 1994. 
${ }^{7}$ O terceiro módulo não é aqui comentado por se tratar de questões relativas a aspectos tributários afeitos a estratégias por meio de legislação diferenciada, não sendo objeto desta tese o tema.

8 O empresário Ricardo Simões já havia contatado anteriormente o arquiteto Wilson Jorge, consultor da Agência de Desenvolvimento Tietê-Paraná, para elaborar um parecer sobre o potencial de desenvolvimento de Ourinhos.

${ }^{9}$ Extraído de declarações publicadas pela imprensa local da região de Ourinhos por ocasião da fundação da ADEO.

${ }^{10} \mathrm{O}$ cargo na ocasião era ocupado pelo autor desta tese.

${ }^{11}$ Toshio Misato teve seu mandato suspenso em novembro de 1999.

12 Destaca-se o impacto do projeto da Incubadora Empresarial de Ourinhos que deu projeção a ADEO entre todos os projetos semelhantes do SEBRAE no estado de São Paulo, o que fez com que esta instituição a recomendasse como modelo às outras cidades interessadas a participarem de seu Programa de Incubadoras.

${ }^{13}$ Douglass North, prêmio Nobel de economia em 1993 que dividiu com Robert Fogel pelos estudos das relações econômicas e institucionais, considera as instituições como chaves para o desenvolvimento econômico. Ligadas às características de sua região, devem estimular organizações originais, pois é a estrutura institucional que irá prover o incentivo ao arranjo que dita o tipo de habilidade e conhecimento necessário para obter o máximo aproveitamento das transformações econômicas e históricas.

\section{Parte III. Desenvolvimento Industrial Descentalizado}

\section{Introdução}

${ }^{1}$ Hommes, Rudolf - Conflicts and dilemmas of decentralization. Em: Bruno, Michael and Boris Pleskovic (eds.) Annual World Bank Conference on Development Economics - 1995, The World Bank. 1996. Em http://www.ipea. gov.br/ ipeaat $02 . h t m l$

\section{Experiência Italiana}

1 Putnam e sua equipe trabalharam com levantamentos e dados sobre os 20 governos regionais criados pelo governo nacional da Itália. São as regiões: Valle d'Aosta, Trentino, Frulli Veneza, Piemonte, Lombardia, Venecia, EmiliaRomagna, Ligúria, Toscana, Marche, Úmbria, Lácio, Abruzos, Molise, Campânia, Basilicata, Puglia, Calábria, Sicília e Sardenha.

${ }^{2} \mathrm{O}$ voto preferencial é um dispositivo eleitoral italiano que permite ao eleitor indicar sua preferência por um nome na chapa que escolhe nas eleições majoritárias nacionais, é considerado aqui por Putnam como a inexistência de uma cultura cívica do eleitor e da comunidade, pois é reconhecidamente um indicador seguro do personalismo e do sectarismo.

${ }^{3}$ Noth, Douglass C. - Institutions, institutional change and economic peformance, Cambridge University Press, 1990.

${ }^{4}$ http://www.unicamp.br, baseado em comentários de Sérgio Schneider. 
5 Palestra na V Jornada Tecnológica de Londrina, dezembro, 1998, Londrina, Paraná.

\section{Industrialização Descentralizada no Brasil}

1 Entende-se distrito industrial, neste texto, como foi conceituado por Alfred Marshall, referindo-se ao espaço produtivo caracterizado pela especialização flexível onde ocorre um processo industrial descentralizado com a "combinação aparentemente contraditória de concorrência em cooperação", segundo Putnam.

${ }^{2}$ Destaca-se o trabalho pioneiro de José Adelino Medeiros voltado para os pólos tecnológicos brasileiros.

${ }^{3}$ Em http://www.ipea.gov.br/ ipeaat01.html

${ }^{4}$ É importante observar que esta definição do IPEA difere em algum sentido da geralmente aplicada que denota que este tipo de agrupamento produtivo, que não está apenas estabelecido em uma sub-região e pode envolver outras localidades ou áreas urbanas, de modo contíguo ou não, não é exclusivamente industrial, podendo abranger outras atividades da cadeia produtiva como transporte e design, por exemplo.

${ }^{5}$ A definição aplicada, útil na abordagem do IPEA, será aprofundada no corpo no próximo capítulo desta seção.

${ }^{6}$ A Fundação Parque de Alta Tecnologia de São Carlos - FPATSC foi instituída em 1984. Trata-se de uma fundação privada sem fins lucrativos, em que participam: CNPq, Centro de Indústrias do Estado de São Paulo e Prefeitura Municipal de São Carlos, que desempenha o papel de gestora do Pólo. O órgão deliberativo da FPATSC é seu Conselho de Curadores, composto por representantes da Prefeitura Municipal, Secretaria da Ciência, Tecnologia e Desenvolvimento Econômico do Estado de São Paulo, CNPq, CIESP, Universidade Federal de São Carlos, USP e UNESP, além de lideranças comunitárias locais. De acordo com o Prof. Sylvio Goulart Rosa Júnior, fundador e atual diretor presidente da FPATSC, o projeto mais importante da Fundação nos próximos anos deverá ser a consolidação de seu Parque Tecnológico a ser edificado em uma área de $170 \mathrm{mil} \mathrm{m2}$. Em agosto de 1999, a fase de implantação do Parque era a execução de obras de infra-estrutura, tendo sido realizado o levantamento topográfico e executado o projeto, como um distrito industrial tendo sido encaminhado este projeto ao prefeito de São Carlos para sua aprovação.

\section{Os Pólos Tecnológicos}

${ }^{1}$ Torkomian (1992).

${ }^{2}$ A palavra pólo não existe no texto da Política Industrial e de Comércio Exterior, lançada pelo Governo Federal em 26/06/90, sendo que quando aborda a questão da capacitação tecnológica da indústria, a palavra utilizada é parque, porém por razões semânticas, os autores têm adotado a designação "pólo", mais abrangente e genérica.

${ }^{3}$ A aplicação do conceito verdadeiro de pólo ainda é muito incipiente no Brasil, alguns locais denominados pólos contam na verdade com apenas alguma estrutura de incubadora. Tem-se visto algumas iniciativas federais neste contexto, como é o 
caso da intenção demonstrada pelo então ministro Sérgio Mota, de criar centros de produção de produtos de telecomunicação, aproveitando a tendência na época de uma ampla privatização do setor no Brasil registrada em entrevista ao jornal $\mathrm{O}$ Estado de São Paulo, 3 de julho de 1997.

4 Extraído de relatório apresentado pela empresa Andersen Consulting para discussão do comitê executivo do Plano de Desenvolvimento Industrial de Londrina em 1995.

\section{As Tecnópolises}

${ }^{1} \mathrm{O}$ conceito de desenvolvimento sustentável pressupõe um legado permanente de uma geração a outra com manutenção e conservação $a b$ aeterno dos recursos naturais, exigindo-se aí a necessidade de avanços científicos e tecnológicos que ampliem permanentemente a capacidade de utilização, recuperação e conservação destes recursos.

${ }^{2}$ No Brasil ainda não há uma determinação política de incentivo às Tecnópolises, o conceito está limitado às ações locais e regionais, como é o caso de São Carlos, no estado de São Paulo e Londrina e Curitiba, no estado do Paraná que contam essencialmente com as articulações e investimentos locais para desenvolvimento dos projetos.

${ }^{3}$ O programa de desenvolvimento regional das Tecnópolises agregavam, em 1998, 38 regiões, de acordo com informações obtidas no portal da Japan External Trade Organization - Jetro na Internet, http://www.jetro.go.jp, em abril de 2000.

4 Mais uma lei foi implementada em dezembro de 1998 visando apoiar o desenvolvimento regional das Tecnópolises através da facilitação à criação de novos empreendimentos no Japão.

${ }^{5}$ Quadros extraídos do site da Jetro - http://www.jetro.go.jp, em abril de 2000.

${ }^{6}$ Adaptado de Castells \& Hall (1994)

\section{Desenvolvimento Industrial em Londrina}

${ }^{1}$ Tendo em vista o objetivo ilustrativo desta tese não será discutido aspectos polêmicos da colonização do Norte do Paraná, mas é importante registrar visões divergentes como a de José Joffily (1985) que se destaca quanto à análise da estratégia desenvolvimentista aplicada pelos ingleses da Parana Plantations, à qual refere-se ele como predadora e desumana, fruto de articulações de banqueiros internacionais e favorecimentos políticos.

${ }^{2}$ Posseiros, colonos sem títulos de terras que tomam posse de áreas sem titulação em cartório.

${ }^{3}$ Extraído de depoimento gravado por Arthur Thomas, pioneiro da colonização do Norte do Paraná. Em Cernev (1997).

${ }^{4}$ Andersen Consulting (1995).

${ }^{5}$ A manutenção do comitê executivo do PDI é objeto de convênio entre a Prefeitura Municipal de Londrina e a ADETEC, que recebe os recursos públicos e 
os repassa para cobrir as despesas do comitê, incluindo salário do diretor executivo.

6 Barros, Silas Gonçalves de \& Lima, Alexandre Bannwart de Machado Programa Londrina Tecnópolis, documento de circulação interna, ADETEC, fevereiro, 1998.

${ }^{7}$ Kolzow (1987).

${ }^{8}$ Além da reconhecida competência na área acadêmica - a Universidade Estadual de Londrina foi considerada como a melhor do Sul do Brasil -, a cidade sedia um festival internacional de teatro e um festival nacional de música, que lhe dão projeção nacional na área cultural.

9 Apenas para se ter um parâmetro de comparação: a compra, da operadora de telefonia celular AirTouch Communications nos EUA custou à britânica Vodafone Group US\$ 56 bilhões (O Estado de São Paulo, 16 de julho de 1999), enquanto a estatal brasileira Telebrás, embora tenha sido a maior privatização do mundo, atingiu a cifra de US\$ 22 bilhões (O Estado de São Paulo, 31 de dezembro de 1998).

${ }^{10} \mathrm{Na}$ falta de uma melhor colocação, setor aqui está identificado como uma aplicação provisória para alta tecnologia que não é propriamente um setor mas, um abrangente mercado onde diversas áreas de pesquisa tão diversificadas quanto imprevisíveis convivem. Elas podem ser voltadas para a área de informação, de biotecnologia, de telecomunicações, de software, ou onde se exija alto grau de especialização das técnicas.

${ }^{11}$ World Bank (1995).

\section{Parte IV. Impacto da Globalização no Desenvolvimento Econômico Local}

\section{Introdução}

${ }^{1}$ Significa dizer que este conjunto é sistêmico, portanto podemos admitir que a globalização constitui um paradigma para a compreensão dos diferentes aspectos da realidade contemporânea. Santos (1994).

2 Por economia mundial entendem-se a economia do mundo globalmente considerado, o mercado de todo o planeta.

\section{Sociedade de Risco}

${ }^{1}$ Baseado em entrevista de Ulrich Beck a José Galisi Filho, Folha de São Paulo, 23 de maio de 1999.

${ }^{2}$ Baseado em entrevista de Anthony Giddens a Rogério Pacheco Jordão, Folha de São Paulo, 23 de maio de 1999, e na obra do autor citada na bibliografia da tese.

${ }^{3}$ Alternativa político-institucional distinta da social-democracia tradicional e do neoliberalismo.

\section{Catástrofe Urbana}


${ }^{1}$ Baseado em entrevista com Paul Virílio à Betty Milan, para a Folha de São Paulo em 28 de setembro de 1997, e nas obras do autor citadas na bibliografia da tese.

\section{Sociedade em Rede}

${ }^{1}$ Baseado em entrevista com Manuel Castells à Folha de São Paulo em 23 de maio de 1999, concedida a Maria Ercília e José Roberto de Toledo, e nas obras do autor citadas na bibliografia da tese.

${ }^{2}$ A desterritorialização é uma perspectiva nova para o sujeito do conhecimento que não permanece no mesmo lugar, tem o olhar que flutua livre e atento por muitos lugares, próximos e remotos, presente e pretéritos, reais e imaginários. Em Ianni, 1999.

${ }^{3}$ Constatou-se, reunindo estatísticas de 1989 a 1998, a partir de pesquisas do IBGE, que os melhores empregos estão ficando em São Paulo, graças a sua capacidade de atrair empresas de ponta compensando as perdas decorrentes da evasão industrial. Nestes últimos dez anos, mesmo diante da guerra fiscal levados adiante por estados para convencer empresas a abandonarem suas localizações paulistas, o estado, e mais particularmente a Região Metropolitana de São Paulo, continuou ampliando sua participação no Brasil em matéria de postos nobres de trabalho (O Estado de São Paulo, 23 de agosto de 1999).

\section{Limites do Estado}

${ }^{1}$ Baseado em artigo de Jürgen Habermas publicado na Folha de São Paulo, 18 de Julho de 1999.

\section{Desenvolvimento sem Trabalho}

${ }^{1}$ R. Dahrendorf - Al di là della crisi, Bari, Laterza, 1984. Em Masi (1999).

\section{Parte V. Conclusão - A Cidade Cognitiva: Proposição para o Desenvolvimento Econômico Local na Era do Conhecimento}

\section{O Problema: Desenvolvimento Local na Era do Conhecimento}

${ }^{1}$ Este mesmo problema é enfrentado nos pólos tecnológicos brasileiros e detectado também em Sophia Antipolis. Mas, se por um lado, no Japão os centros de decisão são indústrias nipônicas com matrizes no eixo Tóquio-Osaka, tanto na França quanto no Brasil esta síndrome deriva de empresas multinacionais com sedes em outros países, onde as decisões de investimentos e pesquisas são tomadas.

\section{A Proposição: A Cidade Cognitiva}

${ }^{1}$ Drucker (2000).

2 Schwartz, Gilson - Nova competição global exige política cultural, Tendências Internacionais, Folha de São Paulo, 12 de dezembro de 1999. 
${ }^{3}$ Henton, Doug \& Walesh, Kim - Linking the New Economy to the Livable Community, The James Irvine Foundation, Abril, 1998. Em http://www.coecon. com /ahwahnee.pdf, maio, 2000.

${ }^{4} \mathrm{O}$ fato de que esta complexidade é cumulativa, o rápido avanço do poder do conhecimento e a rede criada para facilitar a crescente economia digital, fazem ainda mais relevantes as considerações de Max Weber sobre a importância da cultura e valores cívicos de uma sociedade para seu crescimento econômico, pois são estas condições abstratas e fatores não materiais que dão sustentação aos fluxos de informação que viabilizam o desenvolvimento de uma região. 